\title{
Estimates of Roughness Coefficients for Selected Natural Stream Channels with Vegetated Banks in New York
}

By WILLIAM F. COON

Prepared in cooperation with the

New York State Department of Transportation

U.S. GEOLOGICAL SURVEY OPEN-FILE REPORT 93-161

Ithaca, New York

1995 


\section{U.S. DEPARTMENT OF THE INTERIOR \\ BRUCE BABBITT, Secretary}

U.S. GEOLOGICAL SURVEY

GORDON P. EATON, Director

For additional information

write to:

Subdistrict Chief

U.S. Geological Survey

903 Hanshaw Road

Ithaca, NY 14850
Copies of this report can be be purchased from:

U.S. Geological Survey Earth Science Information Center Open-File Reports Section

Box 25286, MS 517

Denver Federal Center

Denver, CO 80225 


\section{CONTENTS}

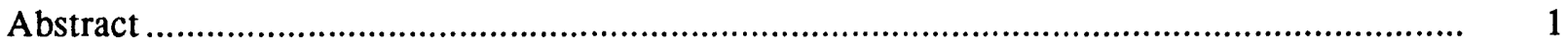

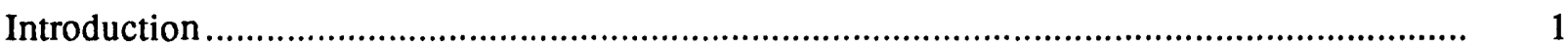

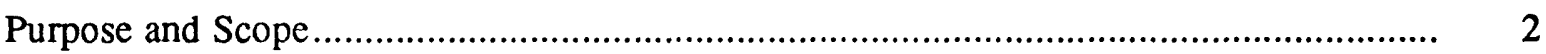

Common Methods for Estimating Roughness Coefficients ...................................... 2

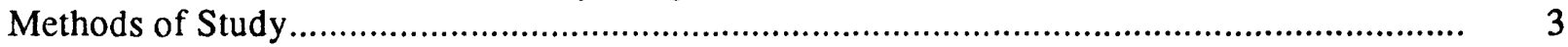

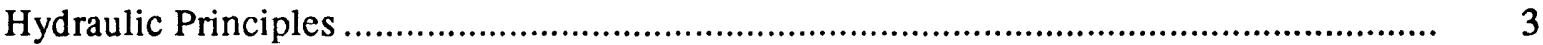

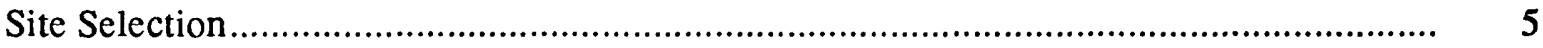

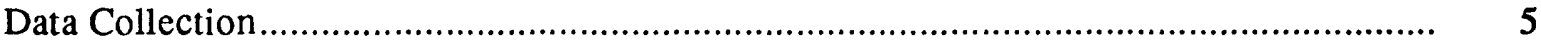

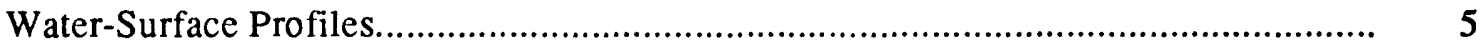

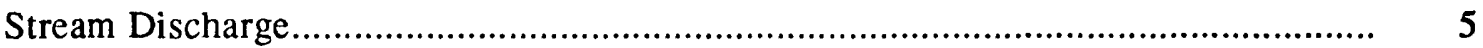

Streambed-Particle Size ........................................................................... 5

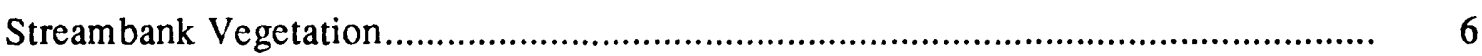

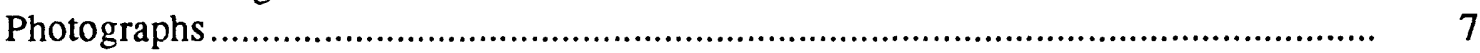

Computation of Hydraulic Properties and Manning's Roughness Coefficients ................ 7

Analysis of Roughness-Coefficient Data...................................................................... 8

Relation Between Manning's Roughness Coefficient and Selected Variables .................. 8

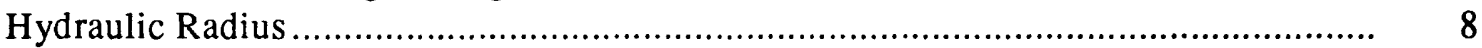

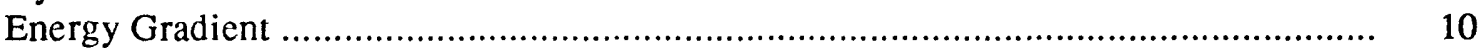

Streambed-Particle Size and Relative Smoothness............................................ 10

Streambank Vegetation.............................................................................. 12

Comparison of Observed with Published Adjustment Values ..................................... 19

Evaluation of Roughness-Coefficient Explanatory Variables ........................................ 20

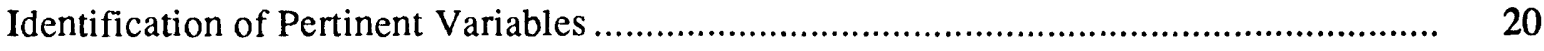

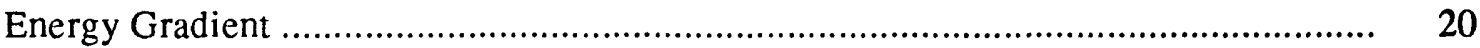

Hydraulic Radius and Relative Smoothness ....................................................... 20

Energy Gradient and Relative Smoothness .......................................................... 20

Type and Density of Streambank Vegetation .................................................... 20

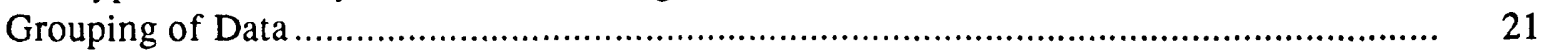

Assessment of Published Equations ................................................................... 21

Procedure for Estimating Roughness Coefficients for Natural Stream Channels ..................... 25

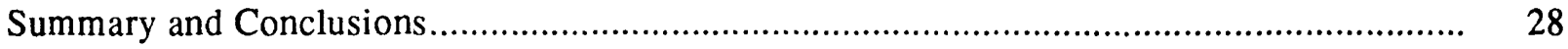

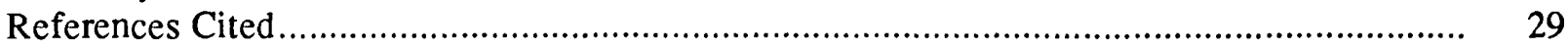

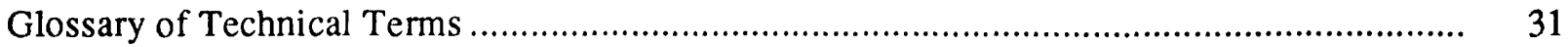

Appendixes

1. Review of Related Studies and Common Methods Used to Estimate Manning's

Roughness Coefficient........................................................................................... 33

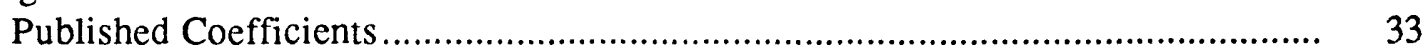

Comparison of Photographs.................................................................... 35

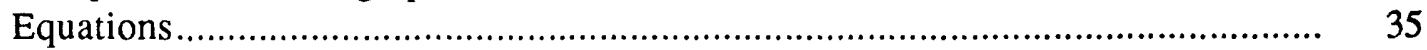

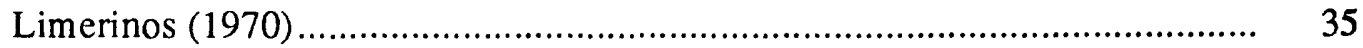

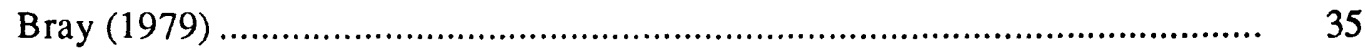

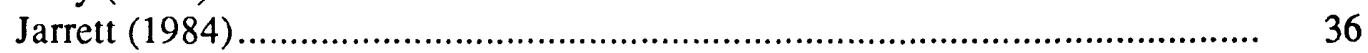

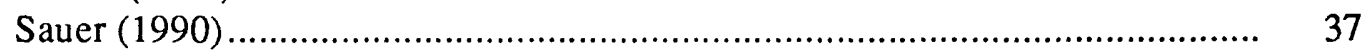

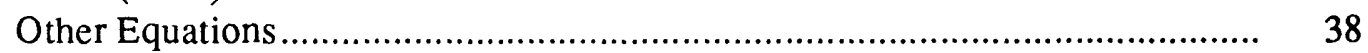

Evaluation of Flow-Retarding Factors ....................................................... $\quad 38$

Considerations for Areas Affected by Vegetation ............................................ 39

2. Photographs, Station Descriptions, and Hydraulic Data for Each Site ....................... 43 


\section{FIGURES}

1. Sketch of an Open-Channel Flow Reach ................................................... 4

2. Map of New York Showing Locations of Study Sites .................................... 6

3-8. Graphs Showing Relation Between:

3. Manning's Roughness Coefficient and Hydraulic Radius for Two Channels Where the Ratio of Hydraulic Radius to the Median Particle Size of Streambed Material $\left(\mathrm{R} / \mathrm{d}_{50}\right)$ is Greater than $5(\mathrm{~A})$, and Two Channels Where These Values are Equal to or Less Than 5 (B)

4. Manning's Roughness Coefficient and Energy Gradient for High Within-Bank Flows

5. Manning's Roughness Coefficient and Streambed Particle Size (Intermediate Diameter $d_{50}$ ) for High Within-Bank Flows

6. Manning's Roughness Coefficient and Relative Smoothness Values, $\mathrm{R} / \mathrm{d}_{50}$ and $\mathrm{R} / \mathrm{d}_{84}$, Based on the Intermediate Particle-Size Diameters for Wide Channels (More Than $100 \mathrm{ft}$ Wide) and Narrow Channels with no Measurable Roughness Effect from Streambank Vegetation.

7. Percentage of Wetted Perimeter that is Vegetated and RoughnessCoefficient-Adjustment Value for Streambank Vegetation During Nongrowing and Growing Seasons

8. Manning's Roughness Coefficient and Hydraulic Radius as Affected by Streambank Vegetation During the Nongrowing and Growing Seasons at (A) Tremper Kill near Andes, N.Y., (B) Scajaquada Creek at Buffalo, N.Y., (C) Moordener Kill at Castleton-on-Hudson, N.Y., and (D) Canisteo River at Arkport, N.Y.

9. Sample Roughness-Coefficient-Evaluation Form

\section{APPENDIX FIGURES}

A1-1. Graph showing relation of stream power and median grain size to type of regime flow

A2-1 through 21. Photographs, cross sections, plan view of each site, with graph showing relation between hydraulic radius and Manning's roughness coefficient

1. Tremper Kill near Andes .....

2. Scajaquada Creek at Buffalo.

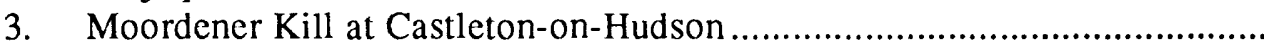

4. Canisteo River at Arkport ............................................................. 57

5. Mill Brook near Dunraven.................................................................... 61

6. East Branch Ausable River at Au Sable Forks .................................... 65

7. Beaver Kill at Cooks Falls ................................................................... 69

8. Onondaga Creek at Dorwin Avenue, Syracuse ....................................... 73

9. Toughnioga River at Itaska ............................................................. 77

10. Kayaderosseras Creek near West Milton .......................................... 81

11. Indian River near Indian Lake .......................................................... 85

12. Sacandaga River at Stewarts Bridge, near Hadley ................................. $\quad 89$

13. Esopus Creek at Coldbrook ............................................................ 93

14. East Branch Delaware River at Margaretville ........................................ 97

15. Ouleout Creek at East Sidney ........................................................ 101

16. Susquehanna River at Unadilla ..................................................... 105

17. Unadilla River at Rockdale .............................................................. 109 
18. Toughnioga River at Cortland ......................................................... 113

19. Chenango River near Chenango Forks.......................................... 117

20. Genesee River near Mount Morris .................................................. 121

21. Trout River at Trout River............................................................ $\quad 125$

\section{TABLES}

1. Range of Hydraulic Characteristics, Particle Sizes, and Roughness Coefficients Among the 21 Study Sites in New York

2. Correlation Coefficients for Selected Hydraulic andStreambed ParticleSizeCharacteristics for the 21 Study Sites in New York

3. Description and Index of Streambank Vegetation of Study Sites, New York

4. Incremental Effects of Streambank Vegetation on the Roughness Coefficient.

5. Differences Between n Values Computed from Study-Site Data and Those Estimated From Published n-Value Equations

6. Best Estimates of $n$ Values Computed from the Study-Site Data by Selected Published Equations for High Within-Bank Flows

\section{APPENDIX TABLES}

A1-1. Base Values of Manning's Roughness Coefficient ............................... 34

A1-2. Values of Manning's Roughness Coefficient for Natural Channels ........... 36

A1-3. Values of Manning's Roughness Coefficient for Modified Channels........ 37

A 1-4. Adjustment Factors for the Calculation of Channel n Values.................... 40

A2-1 through 21. Station Descriptions and Summaries of Hydraulic Data

1. Tremper Kill near Andes ............................................................... 44

2. Scajaquada Creek at Buffalo.......................................................... 48

3. Moordener Kill at Castleton-on-Hudson ............................................. 52

4. Canisteo River at Arkport ................................................................. 56

5. Mill Brook near Dunraven........................................................... $\quad 60$

6. East Branch Ausable River at Au Sable Forks ...................................... 64

7. Beaver Kill at Cooks Falls ................................................................... 68

8. Onondaga Creek at Dorwin Avenue, Syracuse ................................... $\quad 72$

9. Toughnioga River at Itaska.......................................................... 76

10. Kayaderosseras Creek near West Milton ......................................... $\quad 80$

11. Indian River near Indian Lake .......................................................... 84

12. Sacandaga River at Stewarts Bridge, near Hadley ................................ 88

13. Esopus Creek at Coldbrook ............................................................. 92

14. East Branch Delaware River at Margaretville ...................................... 96

15. Ouleout Creek at East Sidney ......................................................... 100

16. Susquehanna River at Unadilla ................................................. 104

17. Unadilla River at Rockdale........................................................... 108

18. Toughnioga River at Cortland ................................................. 112

19. Chenango River near Chenango Forks.......................................... 116

20. Genesee River near Mount Morris .................................................. 120

21. Trout River at Trout River......................................................... 124 


\section{CONVERSION FACTORS}

\begin{tabular}{rll}
\hline Multiply & By & To obtain \\
\hline inch $(\mathrm{in})$. & 25.4 & millimeter \\
foot $(\mathrm{ft})$ & 0.3048 & meter \\
square foot $\left(\mathrm{ft}^{2}\right)$ & 0.09294 & square meter \\
foot per second $\left(\mathrm{ft}_{\mathrm{s}}\right)$ & 0.3048 & meter per second \\
cubic foot per second $\left(\mathrm{ft}^{3} / \mathrm{s}\right)$ & 0.02832 & cubic meter per second \\
mile $(\mathrm{mi})$ & 1.609 & kilometer \\
square mile $\left(\mathrm{mi}^{2}\right)$ & 2.590 & square kilometer \\
pound, avoirdupois $(\mathrm{lb})$ & 0.4536 & kilogram \\
\hline
\end{tabular}




\section{LIST OF SYMBOLS}

A Cross-sectional area of flow $\left(\mathrm{ft}^{2}\right)$.

D Hydraulic or mean depth ( $\mathrm{ft}$ ).

$d_{p}$ Particle diameter that equals or exceeds that of p percent of the bed material (ft).

$F$ Froude number.

g Gravitational acceleration constant $\left(\mathrm{ft} / \mathrm{s}^{2}\right)$.

h Hydraulic (piezometer) head (ft).

$\mathrm{h}_{\mathrm{f}}$ Energy loss due to boundary friction.

$h_{v}$ Velocity head $(\mathrm{ft})$.

$\mathrm{K}$ Conveyance $\left(\mathrm{ft}^{3} / \mathrm{s}\right)$.

$\mathrm{k}$ Expansion or contraction energy-loss coefficient.

$\mathrm{L}$ Length of channel reach ( $\mathrm{ft}$ ).

$\mathrm{L}_{\mathrm{m}}$ Channel-meander length ( $\mathrm{ft}$ ).

$\mathrm{L}_{\mathrm{s}}$ Valley or straight-channel length ( $\mathrm{ft}$ ).

$\mathrm{n}$ Manning's roughness coefficient $\left(\mathrm{ft}^{1 / 6}\right)$.

$\mathrm{n}_{0}$ Base value of $\mathrm{n}$ for surface material of a straight, uniform channel $\left(\mathrm{ft}^{1 / 6}\right)$.

$\mathrm{n}_{1}$ Additive value of $\mathrm{n}$ to account for effect of cross-section irregularity $\left(\mathrm{ft}^{1 / 6}\right)$.

$\mathrm{n}_{2}$ Additive value of $\mathrm{n}$ to account for variations in size and shape of channel $\left(\mathrm{ft}^{1 / 6}\right)$.

$\mathrm{n}_{3}$ Additive value of $\mathrm{n}$ to account for effect of obstructions $\left(\mathrm{ft}^{1 / 6}\right)$.

$\mathrm{n}_{4}$ Additive value of $\mathrm{n}$ to account for type and density of vegetation $\left(\mathrm{ft}^{1 / 6}\right)$.

$m$ Adjustment factor for degree of channel meandering; also total number of cross sections in a reach.

$P$ Wetted perimeter $(\mathrm{ft})$.

Q Discharge $\left(\mathrm{ft}^{3} / \mathrm{s}\right)$.

$R$ Hydraulic radius ( $\mathrm{ft}$ ).

$R / d_{p}$ Relative smoothness.

$\mathrm{S}_{\mathrm{f}}$ Energy gradient or friction slope $(\mathrm{ft} / \mathrm{ft})$.

$\mathrm{S}_{\mathrm{w}}$ Slope of water surface $(\mathrm{ft} / \mathrm{ft})$.

SP Stream power $\left[(\mathrm{ft}-\mathrm{lb} / \mathrm{s}) / \mathrm{ft}^{2}\right]$.

$\mathrm{T}$ Top width of stream (ft).

$\mathrm{V}$ Mean velocity of flow (ft/s).

$\propto$ Velocity-head or kinetic-energy coefficient.

$\theta$ Angle of channel slope (degrees). 


\title{
Estimates Of Roughness Coefficients For Selected Natural Stream Channels With Vegetated Banks In New York
}

\author{
By William F. Coon
}

\begin{abstract}
Water-surface profiles were recorded and Manning's roughness coefficients computed for a range of discharges at 21 sites on unregulated streams in New York State, excluding Long Island. All sites are at or near U.S. Geological Survey streamflowgaging stations at which stage-to-discharge relations are relatively stable and overbank flow is absent or minimal. Crest-stage gages were used to record water-surface profiles. The channels included in the study have the following ranges in hydraulic characteristics: hydraulic radius, 0.91 to 13.4 feet; water-surface slope, 0.0003 to 0.014 ; and instantaneous or peak discharge, 77 to 51,700 cubic feet per second. The 84th percentile of the intermediate diameter of bed material ranges from 0.14 to 3.0 feet. Computed Manning's roughness coefficients (n values) range from 0.024 to 0.129 . On channels with coarse-grained bed material, the relation between the computed $n$ value and flow depth can be predicted from the energy gradient, relative smoothness (ratio of hydraulic radius or mean depth to a characteristic particle size of the bed material), stream-top width, and channel-vegetation density. The percentage of wetted perimeter that is vegetated can be used as an indicator of energy losses that are attributable to

streambank vegetation. Bank vegetation generally has no measurable effect on the roughness coefficients of streams wider than 100 feet if less than 25 percent of the wetted perimeter is vegetated. For wide channels in which larger percentages of wetted perimeter are vegetated, bank vegetation appears to have a small additive effect on the roughness coefficient. On narrow channels ( 30 to 63 feet wide) in which the wetted perimeter is typically more than 25 percent vegetated, the magnitude of the energyloss effect of streambank vegetation depends on the season and on the type, density, and percent submergence of the vegetation. The presence of trees and brush on the banks of narrow channels increased the $\mathrm{n}$ value by as much as 0.005 in the nongrowing season and by an additional 0.002 to 0.012 during the growing season. This report discusses common methods of estimating Manning's roughness coefficients for stream channels, including use of published n-value data, comparison with photographs of channels for which $n$ values have been computed, and $n-$ value equations. It also describes a procedure for evaluating flow-retarding factors of a channel and includes photographs and hydraulic data from the 21 channels studied.
\end{abstract}

\section{INTRODUCTION}

Calculations of stream discharge and flood-water elevations require evaluation of the flow-impeding characteristics of stream channels and their banks. Manning's roughness coefficient (n) is commonly used to assign a quantitative value to represent the collective effect of these characteristics. The procedure for estimating $\mathrm{n}$ values generally is subjective, and the accuracy is largely dependent on a hydrologist's or engineer's experience in estimating these values over a wide range of hydraulic conditions. Even experienced hydrologists

sometimes have difficulty in assessing accurately all the factors that contribute to flow resistance. For example, Riggs (1976) compared computed roughness coefficients for 30 reaches in the United States (from Barnes, 1967) with $n$ values estimated by experienced hydrologists and concluded that experienced hydrologists can make acceptable estimates of $n$ values for many, but not all, channels. Trieste and Jarrett (1987) noted that $n$ values estimated by experienced hydrologists for five large floods (overflowing the bank) in 
natural channels were, on the average, about one-half the computed values.

The roughness coefficient incorporates the many factors that contribute to the loss of energy in a stream channel. The major factor is channel-surface roughness, which is determined by the size, shape, and distribution of the grains of the material that line the bed and sides of the channel (the wetted perimeter). Five other main factors are channel-surface irregularity, channelshape variation, obstructions, type and density of vegetation, and degree of meandering (Cowan, 1956). Five additional factors that affect energy loss in a channel are depth of flow, seasonal changes in vegetation, amount of suspended material, bedload, and changes in channel configuration due to deposition and scouring (Chow, 1959). Several other factors that contribute to energy losses during large floods include unsteady flow, flood-plain flow that crosses the main channel in a meander bend, transport and jamming of debris, extreme turbulence, bedforms in noncohesive bed material, and shear stresses at the interface between flood plain and main channel (Trieste and Jarrett, 1987). The interaction of two or more of these factors could further affect channel energy loss. Although these factors are identifiable, their individual contributions to the total roughness are difficult, if not impossible, to quantify. As a result, several methods for estimating $n$ values have been developed.

In response to a need for assessment of roughness coefficients that are representative of stream channels throughout New York State, the U.S. Geological Survey (USGS), in cooperation with the New York State Department of Transportation, conducted a statewide roughness-coefficient study during 1983-88. Objectives were to (1) compute Manning's roughness coefficients (n) for selected channels with characteristics representative of New York streams, (2) quantify the increment of flow resistance that could be attributed to specific flow-retarding factors, particularly streambank vegetation, (3) assess the transferability of these values to other streams, and (4) compile and maintain for each site a file that includes a site description, hydraulic data, and photographs or slides that could be used for office- and field-training exercises.

\section{Purpose and Scope}

This report (1) presents the methods of n-value calculation, site selection, and data collection and computation for the 21 selected sites; (2) describes the change in roughness coefficient associated with some of the major factors that influence roughness coefficients-flow depth, energy gradient, size of bed material, and bank vegetation; (3) evaluates published nvalue equations and their ability to reproduce the $n$ values calculated from the study-site data; and (4) presents a procedure for assigning $n$ values to natural channels not studied. Appendix 1 summarizes related studies and presents data, equations, and references that aid in estimating Manning's roughness coefficient. Appendix 2 presents (1) a station description and tabulation of computed roughness coefficients and corresponding hydraulic data for a range of discharges at each of the study sites, (2) two photographs (upstream and downstream views) of each site, and (3) a plan view and crosssection sketches of each site.

\section{Common Methods for Estimating Roughness Coefficients}

The hydraulic complexities involved in estimating roughness coefficients have led to the development of several roughness-evaluation aids, including n-value tables, photographs for comparison, and equations. Although these aids do not eliminate subjectivity in the selection of $\mathbf{n}$ values, they simplify the estimation process by including only the most significant flow-resisting factors on the assumption that the remaining factors have a negligible effect. The methods of several researchers are explained in detail in appendix 1 , which provides tables of (1) base $n$ values from Aldridge and Garrett (1973), which is a relisting of values originally presented by Benson and Dalrymple (1967), Chow (1959), and Bray (1979) (table A1-1); (2) n values for natural channels with and without additional flow-resisting factors (Chow, 1959) (table A1-2); and (3) $n$ values for modified channels (Jarrett, 1985) (table A1-3).

Roughness coefficients also can be estimated by comparison of a site of interest with published photographs of similar channels for which $\mathrm{n}$ values have been computed. Ramser (1929) includes channel photographs in a report on drainage channels, and Scobey (1939) presents photographs of irrigation channels. Parts of these reports have been reproduced in Chow (1959) and Fasken (1963). Bames (1967) illustrates 50 channels in color photographs of natural streams from across the United States that represent a wide range of hydraulic characteristics. Aldridge and Garrett (1973) present photographs of 35 predominantly sand-bed channels in Arizona. 
Many researchers have studied the relations between flow resistance and channel hydraulic characteristics and(or) representative sizes of bed material and have developed equations to estimate $n$ values from these relations. Limerinos (1970) presents an equation (eq. A-2, p. 35) based on hydraulic radius and relative smoothness $\left(R / d_{84}\right)$. For channels that lack information on bed particle size, Bray (1979) has proposed an alternative equation (eq. A-3, p. 35), based on water-surface slope alone, for high withinbank flows on gravel channels. Jarrett (1984) relates $\mathbf{n}$ to hydraulic radius and friction slope for highgradient streams (eq. A-4, p. 36). V. B. Sauer (U.S. Geological Survey, written commun., 1990) developed an equation (eq. A-5, p. 38) that is similar in form to that of Jarrett (1984) but is based on a broader range of hydraulic characteristics and thus gives different estimates of $n$. Each of these equations is based on a specific data set with a finite range in and limited representation of hydraulic and particle-size characteristics. Therefore, use of these equations is lim-

\section{METHODS OF STUDY}

The following sections present the hydraulic principles on which calculation of a channel's roughness coefficient is based and describe the methods of site selection, data collection, and computation that were used in this study. The equations used in the calculation of roughness coefficients are numbered 1 through 7 below; those numbered 8 through 19 (table 5, p. 22) are published equations used to estimate $n$ values. Equations that have general applicability or special significance for the New York study sites are described in appendix 1 and are numbered A-1 through A-8.

\section{Hydraulic Principles}

The most widely used uniform-flow formula for open-channel flow computations is the Manning equation (Chow, 1959):

$$
\mathrm{V}=\frac{1.486}{\mathrm{n}} \mathrm{R}^{2 / 3} \mathrm{~S}_{\mathrm{f}}^{1 / 2}
$$

where $V=$ mean velocity of flow, in feet per second,

$\mathrm{R}=$ hydraulic radius, in feet,

$S_{\mathrm{f}}=$ energy gradient or friction slope, in feet per foot, and ited to channels with characteristics similar to those on which the equations are based.

These roughness-evaluation aids-tables, photographs, and equations - can be incorporated into a step-by-step estimation process presented by Cowan (1956). The general approach of this method is to (1) select a base $n$ value for a straight, uniform, smooth channel in the natural materials of the streambed and banks; (2) add modifying values for roughness-increasing factors, including channel-surface irregularity, channel-shape variation, obstructions, and vegetation; and (3) multiply the sum of these values by a factor that accounts for meandering in the reach. The magnitude of Cowan's (1956) modifying values implies that, of these factors, channel vegetation has the greatest potential effect on the total roughness coefficient selected for a reach. Cowan's (1956) method and considerations for evaluating vegetation-affected roughness coefficients are discussed further in appendix 1.

$$
\mathrm{n}=\text { Manning's roughness coefficient, in }
$$

For any flow, the discharge at a channel section is expressed by

$$
\mathrm{Q}=\mathrm{VA}
$$

where $Q=$ discharge, in cubic feet per second,

$\mathrm{V}=$ mean velocity of flow, in feet per second, and

$\mathrm{A}=$ cross-sectional area of flow, in square feet.

Combining equations 1 and 2 gives the discharge formula

$$
\mathrm{Q}=\frac{1.486}{\mathrm{n}} \mathrm{AR}^{2 / 3} \mathrm{~S}_{\mathrm{f}}^{1 / 2}
$$

Reliable solution of the discharge equation is based on the assumption of uniform flow in which the area, hydraulic radius, and depth remain constant, and the slopes of the water surface, energy gradient, and streambed are parallel. In natural channels these conditions are seldom met, but equation 3 can be assumed valid for reaches of nonuniform flow if the energy gradient is modified to reflect only the en- 
ergy losses due to boundary friction (Barnes, 1967). The energy equation for a reach of nonuniform openchannel flow between cross sections 1 and 2 in figure 1 is

$\left(h+h_{v}\right)_{1}=\left(h+h_{v}\right)_{2}+\left(h_{f}\right)_{1,2}+k\left(\Delta h_{v}\right)_{1,2}$

where the subscript numerals 1 and 2 refer to the upstream and downstream sections, respectively, and

$\mathrm{h}=$ hydraulic head or elevation of the water surface at the respective sections above a common datum, in feet,

$h_{\mathrm{f}}=$ energy loss due to boundary friction in the reach, in feet,

$\Delta \mathrm{h}_{\mathrm{v}}=$ upstream velocity head minus the downstream velocity head, in feet,

$k\left(\Delta h_{v}\right)=$ energy loss due to acceleration or deceleration in a contracting or expanding reach, in feet,

$\mathrm{k}=$ energy-loss coefficient, generally taken to be 0.0 for contracting reaches and 0.5 for expanding reaches, dimensionless, and

$h_{v}=$ velocity head at the respective section, in feet, that equals $\propto \mathrm{V}^{2} / 2 \mathrm{~g}$,

where $\propto=$ velocity-head or kinetic-energy coefficient, dimensionless,

$\mathrm{V}=$ mean velocity of flow, in feet per second, and

$\mathrm{g}=$ gravitational acceleration constant, 32.2 feet per second squared.

In this report, the velocity-head coefficient, $\propto$, in the main channel is considered to be 1.00 for computational purposes. Jarrett (1984) indicates that, in natural channels, $\propto$ can be much greater than 1.00 , but any resulting error in the computation of the $n$ value is assumed to be minimal because the importance lies in the relative difference between the velocity-head coefficients of upstream and downstream cross sections, rather than their actual magnitudes.

The slope of the energy gradient, or friction slope, is thus defined as

$$
S_{\mathrm{f}}=\frac{\mathrm{h}_{\mathrm{f}}}{\mathrm{L}}=\frac{\Delta \mathrm{h}+\Delta \mathrm{h}_{\mathrm{v}}-\mathrm{k}\left(\Delta \mathrm{h}_{\mathrm{v}}\right)}{\mathrm{L}}
$$

where $\Delta \mathrm{h}=$ difference in water-surface elevation at the two sections, in feet, and

$\mathrm{L}=$ length of channel reach, in feet.

Other variables are as previously defined.

The quantity $(1.486 / \mathrm{n}) \mathrm{AR}^{2 / 3}$ in the discharge formula (eq. 3 ) is called the conveyance and is computed for each cross section. The mean conveyance in the reach between any two sections is computed as the geometric mean of the conveyance of the two sections. The discharge equation in terms of conveyance is:

$$
\mathrm{Q}=\left[\mathrm{K}_{1} \mathrm{~K}_{2} \mathrm{~S}_{\mathrm{f}}\right]^{1 / 2}
$$

where $\mathrm{K}=$ conveyance, in cubic feet per second.

Following the method described by Barnes (1967) and Jarrett and Petsch (1985), Manning's roughness coefficient is computed for each reach from the known discharge, the water-surface profile, and the hydraulic properties of the reach as defined by the cross sections. The following equation is applicable to a multisection reach of $\mathrm{m}$ cross sections, designated $1,2,3, \ldots(m-1), m$ (the mth cross section is the one furthest downstream):

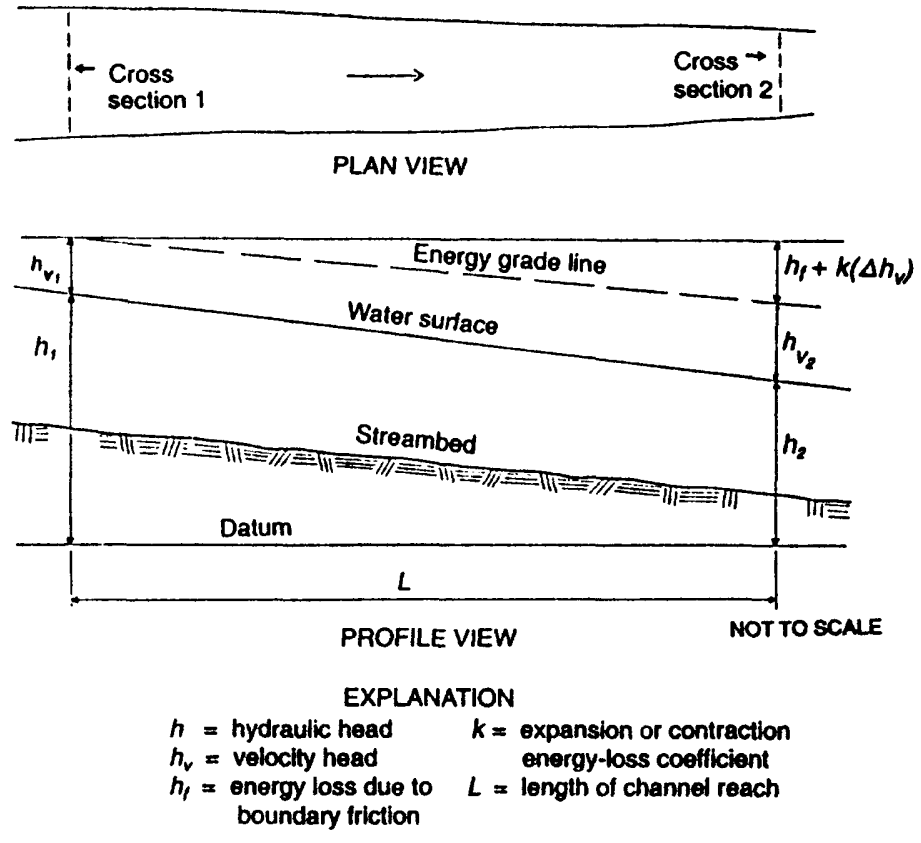

Figure 1. Open-channel flow reach in plan and profile views. (Modified from Dalrymple and Benson, 1967, fig. 1) 


$$
\mathrm{n}=\frac{1.486}{\mathrm{Q}}\left[\frac{\left(\mathrm{h}+\mathrm{h}_{\mathrm{v}}\right)_{1}-\left(\mathrm{h}+\mathrm{h}_{\mathrm{v}}\right)_{\mathrm{m}}-\left[\left(\mathrm{k} \Delta \mathrm{h}_{\mathrm{v}}\right)_{1.2}+\left(\mathrm{k} \Delta \mathrm{h}_{\mathrm{v}}\right)_{2.3}+\cdots+\left(\mathrm{k} \Delta \mathrm{h}_{\mathrm{v}}\right)_{(\mathrm{m}-1) \cdot \mathrm{m}}\right]}{\frac{\mathrm{L}_{1.2}}{\mathrm{Z}_{1} \mathrm{Z}_{2}}+\frac{\mathrm{L}_{2.3}}{\mathrm{Z}_{2} \mathrm{Z}_{3}}+\cdots \frac{\mathrm{L}_{(\mathrm{m}-1) \cdot \mathrm{m}}}{\mathrm{Z}_{(\mathrm{m}-1)} \mathrm{Z}_{\mathrm{m}}}}\right]^{1 / 2}
$$

where $\mathbf{Z}=\mathrm{AR}^{2 / 3}$ and other quantities are as previously defined.

Dalrymple and Benson (1967) describe the procedure for computation of discharge by the slopearea method. Barnes (1967) and Jarrett (1984) used a modification of this procedure as defined by equation 7 to compute roughness coefficients for their nvalue reports, and Jarrett and Petsch (1985) developed a computer program based on this procedure to facilitate the calculation and analysis of computed $n$ values.

\section{Site Selection}

The 21 study sites were selected at or near current U.S. Geological Survey streamflow-gaging stations that have well-defined and relatively stable stage-to-discharge relations. Site locations are shown in figure 2. These sites were selected to meet, as closely as possible, the criteria for selection of a reach for computation of discharge by the slope-area method as outlined by Dalrymple and Benson (1967). Therefore, straight, uniform channels with minimal effect from flow-retarding factors were sought. To evaluate the flow-impeding effects of streambank vegetation, reaches with uniform type and density of vegetation were selected. None of the sites had notable vegetation in their low-water channels, and only sites where high flows are contained within the channel banks or where overflow, if any, is insignificant, were selected. The selected reaches ranged in streamsurface top width from $30 \mathrm{ft}$ to more than $400 \mathrm{ft}$ and in Iength from 101 to $1,340 \mathrm{ft}$.

\section{Data Collection}

Water-surface profiles and stream discharges were obtained throughout the within-bank range in stage at each of the study sites during 1983-88. Channel geometry was surveyed at the beginning of the study and resurveyed if fill or scour within the reach was suspected. The streambed-particle size was measured, streambank vegetation was described, and upstream and downstream views of each reach were photographed.

\section{Water-Surface Profiles}

Water-surface profiles of high flows were drawn from a preliminary indirect calculation of discharge by the slope-area method (Dalrymple and Benson, 1967) and used to locate appropriate cross sections at which hydraulic channel data could be obtained. Standard USGS crest-stage gages (Rantz and others, 1982, p. 77) were installed at each cross section to obtain water-surface profiles of high flows that occurred between site inspections. Water-surface elevations were obtained from leveling runs, routine inspections of crest-stage gages, and direct measurements from reference points. Depending on the timing of the direct measurements, many water-surface profiles that were measured during rising and falling stages of a floodflow produced erroneous slopes and were excluded from the study.

\section{Stream Discharge}

The discharge for each recorded water-surface profile was obtained from the discharge record of the nearby streamflow-gaging station. The stability of the stage-to-discharge relation at each site was checked by discharge measurements, which were conducted in accordance with standard USGS measurement procedures (Rantz and others, 1982). The generally "good" rating of daily discharge records at these sites through the period of study, 1983-88, implies a discharge accuracy within 10 percent of the true discharge. Water-surface profiles recorded during any periods when the stageto-discharge relation was questionable either are noted in appendix 2 or were deleted from the study.

\section{Streambed-Particle Size}

Measurement of streambed-particle size was done in accordance with the methods of Wolman (1954), Benson and Dalrymple (1967), and Kellerhals and Bray (1970), who outlined methods for obtaining representative samples of size and size distribution of coarse bed material. None of the study sites had bed material that was predominantly sand or finer. Random grab samples of bed material were taken at 
equal increments across three to five cross sections within each study reach. All three dimensions of each particle were measured. At most sites, bed material was sampled concurrently with cross-section-elevation measurements.

\section{Streambank Vegetation}

The general type and relative density of streambank vegetation at each site was documented, and the elevation at which vegetation began on each

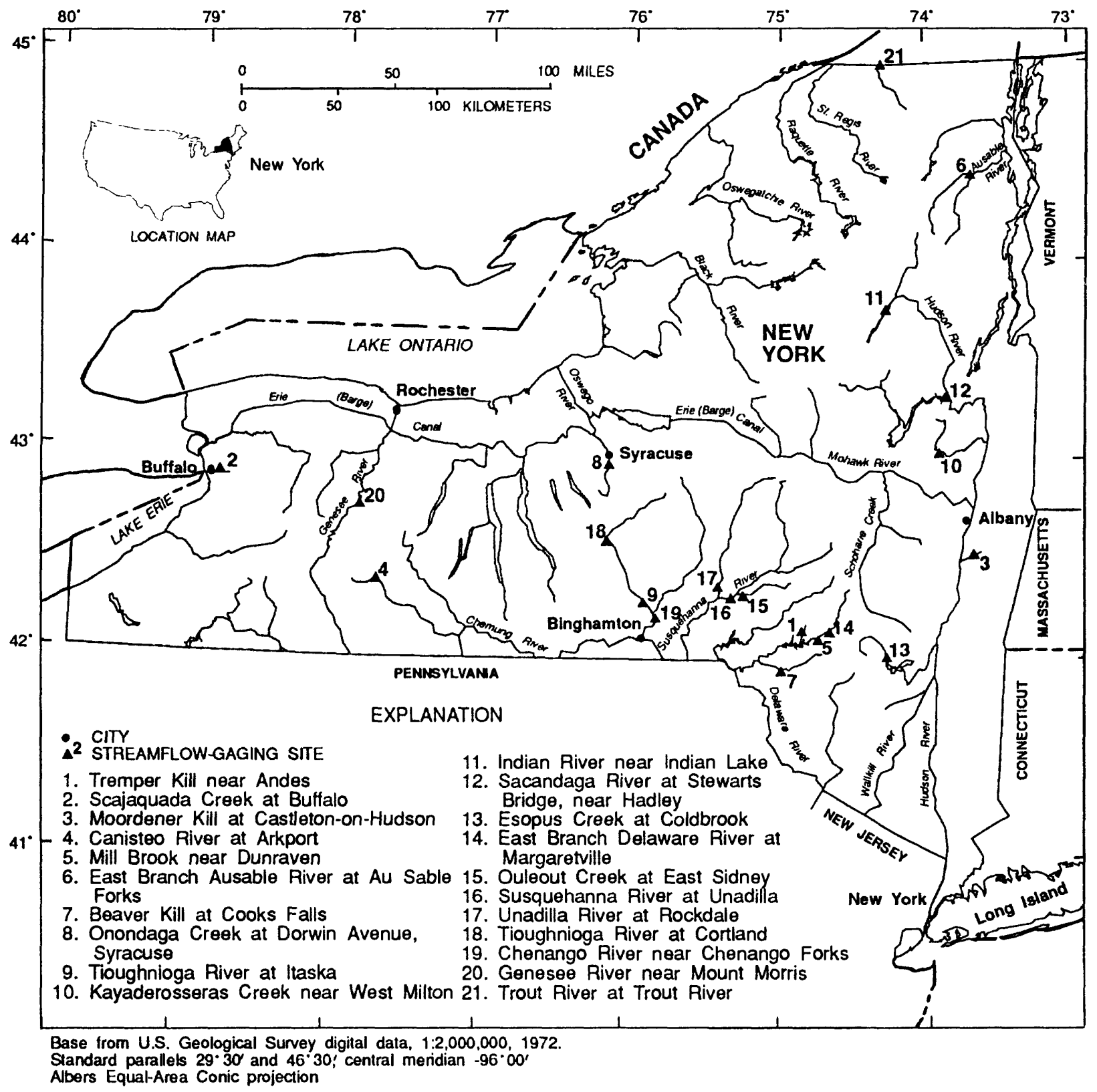

Figure 2. Locations of study sites. 
bank was noted and used to compute the percentage of wetted perimeter that was vegetated for each profile. This elevation generally coincided with the edge of the low-water channel. The elevation was also noted at any point along the cross section where a substantial change in the type or density of vegetation was observed. For purposes of this report, the growing season is the 6month period from May through October; the nongrowing season is from November through April.

\section{Photographs}

An upstream and downstream view of each study reach was photographed; both are included with the hydraulic data for each site in appendix 2 . These photographs show channel alignment, streambank vegetation type and density, channel size in relation to the flow-resisting features of the channel, and, where possible, bed material. As with other photographic n-value reports, hydrologists and engineers can use these photographs, along with the hydraulic data presented, to assist in estimating roughness coefficients for channels with similar characteristics.

\section{Computation of Hydraulic Properties and Manning's Roughness Coefficients}

Water-surface elevations and their associated discharges were input to the n-calculation computer program developed by Jarrett and Petsch (1985). For a given water-surface profile and discharge, the roughness coefficient for each pair of cross sections and for the entire reach was calculated, and the hydraulic properties for each cross section were computed. The intermediate diameter of the streambed particles was used to calculate the diameters that equal or exceed that of 50 percent and 84 percent $\left(\mathrm{d}_{50}\right.$ and $d_{84}$ ) of the particles sampled at a site. The $d_{50}$ for the minimum diameter of the particles was also calculated. Hydraulic and particle-size data, as well as the resulting computed roughness coefficients for each discharge and water-surface profile, are included with the photographs of each site in appendix 2 . The tabulated values for area, stream-top width, hydraulic radius, velocity, and Froude number are averages of values computed for each cross section within a reach. Ranges of 14 major characteristics at the 21 sites are listed in table 1 . Streambank vegetation ranged from grass alone to various combinations and densities of annual weeds, woody brush, and trees.
The average wetted perimeter of the nonvegetated low-water channel and the average wetted perimeter that is vegetated were calculated for each water-surface profile and used to compute the percentage of wetted perimeter that is vegetated; this percentage ranged from 0 to 48 (table 1 ).

One variable that is included in the Manning equation but is not directly measurable is the velocity-head coefficient. For the $n$ calculations, as well as most hydraulic computations of discharge or floodwater elevation, this value is assumed to be 1.00 . As a measure of the validity of this assumption and an indicator of the uniformity of flow at a cross section, current-meter discharge measurements can be used to compute the velocity-head coefficients (Hulsing and others, 1966). This was done at the sites that have cableways or nonconstricting bridge openings that permit high-flow discharge measurements within or close to the study reach. Only 8 of the 21 sites met this criterion; the range of computed velocityhead coefficients for these sites is included with the hydraulic data for each site in appendix 2 . Highflow measurements at the other sites were made at cross sections far from the study site or at bridges that were constricted by the bridge opening or obstructed by piers. The velocity-head coefficients computed for these locations are not representative of the velocity distribution through the study reach and, therefore, are not included in this report.

Table 1. Range of hydraulic characteristics, particle sizes, and roughness coefficients among the 21 study sites in New York

\begin{tabular}{|c|c|c|}
\hline & Minimum & Maxmum \\
\hline $\begin{array}{l}\text { Cross-sectional area of flow } \\
\text { (square feet) }\end{array}$ & 35.9 & 3,910 \\
\hline Top width of stream (feet) & 29.7 & 429 \\
\hline Hydraulic radius (feet) & .91 & 13.4 \\
\hline Mean velocity (feet per second) & 1.40 & 16.8 \\
\hline Froude number & .20 & .91 \\
\hline Water-surface slope (feet per foot) & .0003 & .0141 \\
\hline Energy gradient (feet per foot) & .0003 & .0131 \\
\hline Percent vegetated wetted perimeter & 0 & 48 \\
\hline Discharge (cubic feet per second) & 77 & 51,700 \\
\hline \multicolumn{3}{|l|}{ Particle size: } \\
\hline \multicolumn{3}{|l|}{ Intermediate diameter } \\
\hline $\mathrm{d}_{50}(\mathrm{feet})$ & .05 & 1.2 \\
\hline$d_{84}(f e e t)$ & .14 & 3.0 \\
\hline Minimum diameter $\mathrm{d}_{50}$ (feet) & .02 & .80 \\
\hline Degree of meandering & 1.00 & 1.01 \\
\hline Manning's roughness coefficient & .024 & .129 \\
\hline
\end{tabular}




\section{ANALYSIS OF ROUGHNESS-COEFFICIENT DATA}

A total of 235 water-surface profiles were recorded among the 21 study sites, and the corresponding roughness coefficients were calculated. Of these, 36 profiles and calculations were considerably affected by flow-area expansion in the reach and(or) by a large variation in the $n$ values computed for each subreach for a given water-surface profile and discharge. Although the actual magnitude of these computed $n$ values might be questionable, the apparent relation between the $n$ value and hydraulic radius and the analysis of the variation in the computed $\mathrm{n}$ values at a particular site are considered valid. (These profiles and $n$-value calculations are footnoted in appendix 2.) An additional 72 profiles and their corresponding $n$ values were substantially affected by streambank vegetation or by severe bank irregularities caused by scalloped banks with exposed tree roots. The $n$ values computed for these profiles are analyzed in detail, and the indicated increments of roughness that are attributable to these factors are compared with the roughness-coefficient-adjustment values for vegetation and surface irregularities presented by Cowan (1956) and subsequently modified by Aldridge and Garrett (1973); results of the comparison are discussed in the section "Comparison of observed and published adjustment values." Many of the calculations for densely vegetated narrow channels indicate a large percentage of flow-area expansion. Unlike the previously discussed data, these computations are assumed to validly reflect the expected consequence of increased flow area that results from the increase in flow retardance from streambank vegetation. The remaining 127 profiles and their respective $n$ values, plus 6 profiles and computed $n$ values from the high-gradient channel, East Branch Ausable River at Au Sable Forks (which is also analyzed as a vegetation-affected site), were used in the other analyses, discussed in the following sections.

\section{Relatlon Between Manning's Roughness Coefficient and Selected Variables}

The degree of association between the roughness coefficient and the measured or computed hydraulic characteristics for the 21 study sites is identified by means of a correlation matrix in table 2 . The four variables that show strong correlation with the roughness coefficient are hydraulic radius, slope, streambed-par- ticle size, and relative smoothness. The relations among these variables are discussed in the following sections. Variables that have perfect or near-perfect correlation with each other are energy gradient and water-surface slope (0.99 correlation, table 2$)$, hydraulic radius and mean depth (1.00), and stream-top width and wetted perimeter (1.00). These correlations imply that the variables within each pair can generally be substituted for each other without causing significant mathematical error in a linear regression analysis, given a uniform reach for the slope variables and a large channel for the other variables.

\section{Hydraulic Radius}

The basic roughness coefficient for a uniform channel should not vary with depth of flow if the ratio of mean depth (usually hydraulic radius) to size of roughness elements (usually the median value of the intermediate diameter of the streambed particles) is greater than 5 and less than 276 (Benson and Dalrymple, 1967). Channel width is assumed to be large relative to depth of flow, or bank materials are assumed to be the same as bed materials. This relation is substantiated by the hydraulic-data tabulations for each site in appendix 2. Low-gradient, wide channels (greater than $100 \mathrm{ft}$ ) with relative smoothness values $\left(R / d_{s 0}\right)$ greater than 5 have nearly constant $n$ values through their respective ranges in stage, as shown by the $n-t o-R$ plots in figure 3. Although data plots indicate a slight inverse relation between $n$ and $R$, the computed roughness coefficients for most of these sites differ by less than 0.005 from low-flow to bankfull conditions. Streambank vegetation has no measurable effect on roughness coefficients at these sites when less than 25 percent of the wetted perimeter is vegetated.

Channels with low relative smoothness $\left(R / d_{50}\right.$ less than or close to 5) generally are in mountain streams with high gradients and large median bed-particle sizes. The roughness coefficients for streams such as these decrease rapidly with increasing depth and approach an asymptotic value as bankfull stage is approached, as shown by Sargent (1979) and Jarrett (1984). Several of the sites studied show this relation (fig. 3) and had $n$ values that differed by as much as 0.068 from low-flow to bankfull conditions, but most differed by 0.015 to 0.030 . The $n$ values computed for low-flow conditions 
when flow depths are insufficient to allow full development of the velocity profile reflect the effect of energy-loss factors other than boundary-layer friction, which contribute substantially more to the roughness coefficient and produce larger $n$ values than would be computed for higher flows. The pertinent points of this analysis, however, are the inverse relation between $n$ and $\mathrm{R}$ and the magnitude of the change in the roughness coefficient from low-flow to bankfull conditions. The effect of streambank vegetation at these sites when less than 25 percent of the channel's wetted perimeter is vegetated is either reflected in the computed $n$ value or is insignificant.

For narrow channels with dense streambank vegetation where typically more than 25 percent of the channel's wetted perimeter is vegetated and $R / d_{50}$ is greater than 5 , roughness coefficients generally increase with increasing depth of flow. An example is Scajaquada Creek at Buffalo (fig. 2), which has a dense growth of willow saplings at its low-water edge. Roughness coefficients at this site can vary substantially with depth and season, ranging from 0.024 to 0.029 during the nongrowing season and from 0.027 to 0.033 during the growing season. On similar channels where $\mathrm{R} / \mathrm{d}_{50}$ is less than 5, such as Tremper Kill near Andes (fig. 2), effects of streambank vegetation during the nongrowing season are indiscemible. Growing-season effects on the roughness coefficient can be substantial, however. These are discussed more fully in the analysis of "Streambank vegetation" (p. 12).

Table 2. Correlation coefficients for selected hydraulic and streambed particle-size characteristics for the 21 study sites in New York [--, correlation coefficient for this pair of variables is given elsewhere in the table.]

\begin{tabular}{|c|c|c|c|c|c|c|c|c|c|}
\hline \multirow[b]{2}{*}{ Variable } & \multicolumn{9}{|c|}{ Untransformed data } \\
\hline & $\mathbf{R}$ & $\mathrm{T}$ & $S_{f}$ & $S_{w}$ & $d_{50}$ & $d_{84}$ & $\mathrm{R} / \mathrm{d}_{50}$ & $\mathrm{R} / \mathrm{d}_{84}$ & $\mathbf{n}$ \\
\hline Hydraulic radius, $\mathbf{R}$ & 1.00 & -- & -- & -- & -- & -- & -- & -- & -- \\
\hline Top width of stream, T & .44 & 1.00 & -- & -- & -- & -- & -- & -- & -- \\
\hline Energy gradient, $S_{f}$ & -.50 & -.50 & 1.00 & -- & -- & -- & -- & -- & -- \\
\hline Water-surface slope, $S_{w}$ & -.50 & -.52 & .99 & 1.00 & -- & - & -- & -- & -- \\
\hline${ }^{1}$ Particle size, $d_{50}$ & -.18 & -.22 & .80 & .77 & 1.00 & -- & -- & -- & -- \\
\hline${ }^{1}$ Particle size, $d_{84}$ & -.10 & -.23 & .69 & .69 & .90 & 1.00 & -- & -- & -- \\
\hline Relative smoothness, $R / d_{50}$ & .35 & .04 & -.49 & -.50 & -.64 & -.55 & 1.00 & -- & -- \\
\hline Relative smoothness, $\mathrm{R} / \mathrm{d}_{84}$ & .50 & .07 & -.51 & -.51 & -.58 & -.57 & .84 & 1.00 & -- \\
\hline Manning's coefficient, $\mathrm{n}$ & -.50 & -.40 & .86 & .83 & .76 & .60 & -.46 & -.48 & 1.00 \\
\hline
\end{tabular}

\section{Log-transformed data}

\begin{tabular}{lccccccc}
\hline & $\log R$ & $\log S_{f}$ & $\log d_{50}$ & $\log d_{84}$ & $\log \left(R / d_{50}\right)$ & $\log \left(R / d_{84}\right)$ & $\log n$ \\
$\log R$ & 1.00 & -- & -- & -- & -- & -- & -- \\
$\log S_{f}$ & -.60 & 1.00 & -- & -- & -- & -- & -- \\
$\log d_{50}$ & -.20 & .73 & 1.00 & -- & -- & -- & - \\
$\log d_{84}$ & -.24 & .81 & .91 & 1.00 & -- & -- & -- \\
$\log \left(R / d_{50}\right)$ & .62 & -.87 & -.89 & -.84 & 1.00 & -- & - \\
$\log \left(R / d_{84}\right)$ & .66 & -.91 & -.79 & -.89 & .94 & 1.00 & -- \\
$\log n$ & -.65 & .86 & .70 & .75 & -.86 & -.89 & 1.00 \\
& & & & & & & \\
\hline
\end{tabular}

${ }^{1}$ Computed from intermediate dimension of measured particles. See glossary for definitions. 

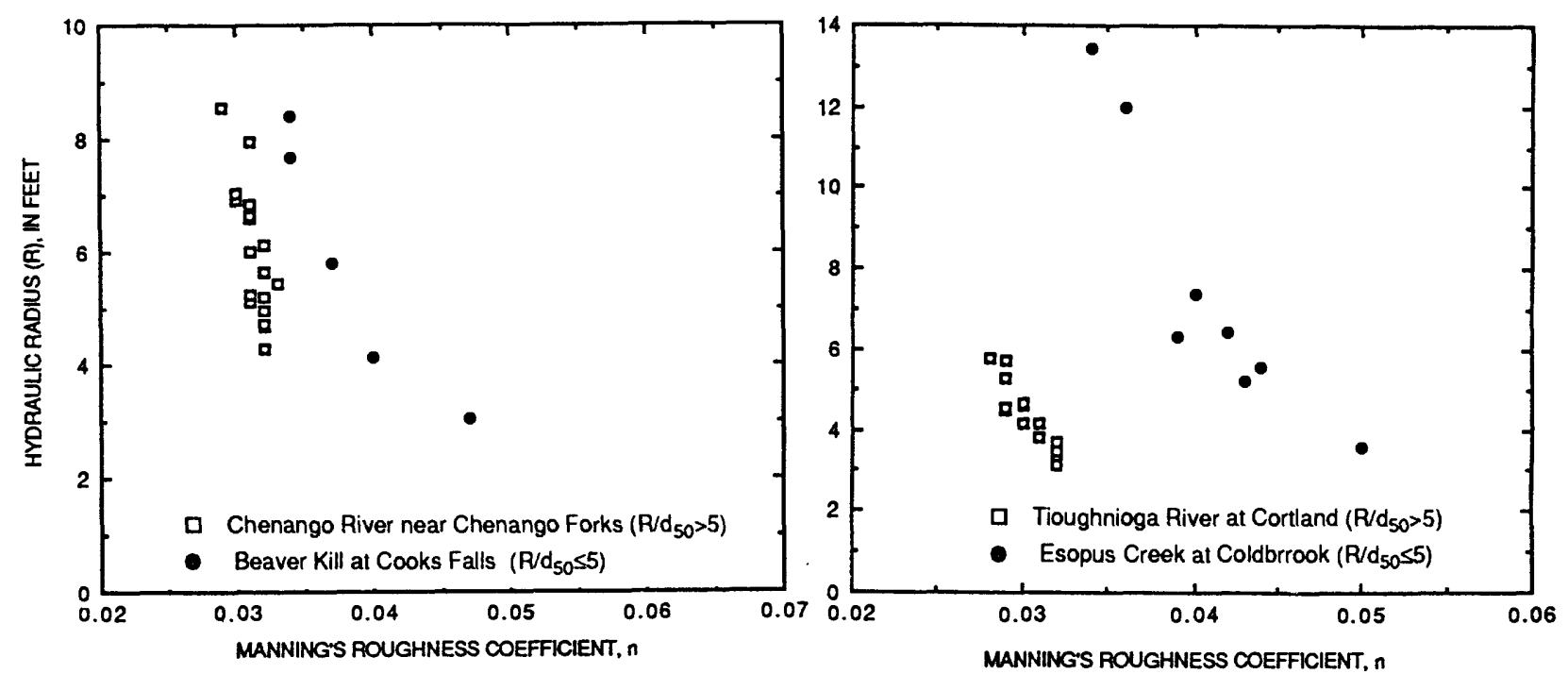

Figure 3. Relation between Manning's roughness coefficient and hydraulic radius for two channels where the ratio of hydraulic radius to the median particle size of streambed material $\left(R / d_{50}\right)$ is greater than 5 (squares), and two channels where these values are equal to or less than 5 (dots). (Locations are shown in figure 2).

\section{Energy Gradient}

Of all the hydraulic factors considered, the two that are most highly correlated with the roughness coefficient are energy gradient (friction slope) and watersurface slope. The correlation coefficient for the n value is slightly higher for energy gradient $(0.86$, table 2$)$ than for water-surface slope (0.83). This close association indicates that hydraulic roughness increases with an increase in slope, as illustrated for high within-bank flows in figure 4. This observation agrees with Riggs' (1976) analysis of Bames' (1967) data, Jarrett's (1984) findings on 21 streams in Colorado, and Bray's (1979) conclusion that slope is a more reliable estimator of the $\mathrm{n}$ value than bed-material size.

\section{Streambed-Partlcle SIze and Relative Smoothness}

Bed-material particle size is closely related to channel roughness and is commonly used as a beginning point for estimating a base $n$ value for a reach. This minimum roughness is a function of the size, shape, spacing, and size distribution of the bed material (Bathurst, 1978). Although many of the study sites have additional roughness factors that contribute to the total channel roughness, the computed $n$ values generally fall within the ranges defined by the bed-material size, as identified by Benson and
Dalrymple (1967) (see table A1-1, p.34) for channels in the following categories: wide channels (more than $100 \mathrm{ft}$ wide) with $\mathrm{R} / \mathrm{d}_{50}$ greater than 5; stages at or near bankfull on wide channels with $\mathrm{R} / \mathrm{d}_{50}$ less than 5; and bankfull stages on narrow channels with little or no streambank vegetation. The relation between the roughness coefficient and the median diameter $\left(d_{50}\right)$ of the intermediate dimension of the bed par-

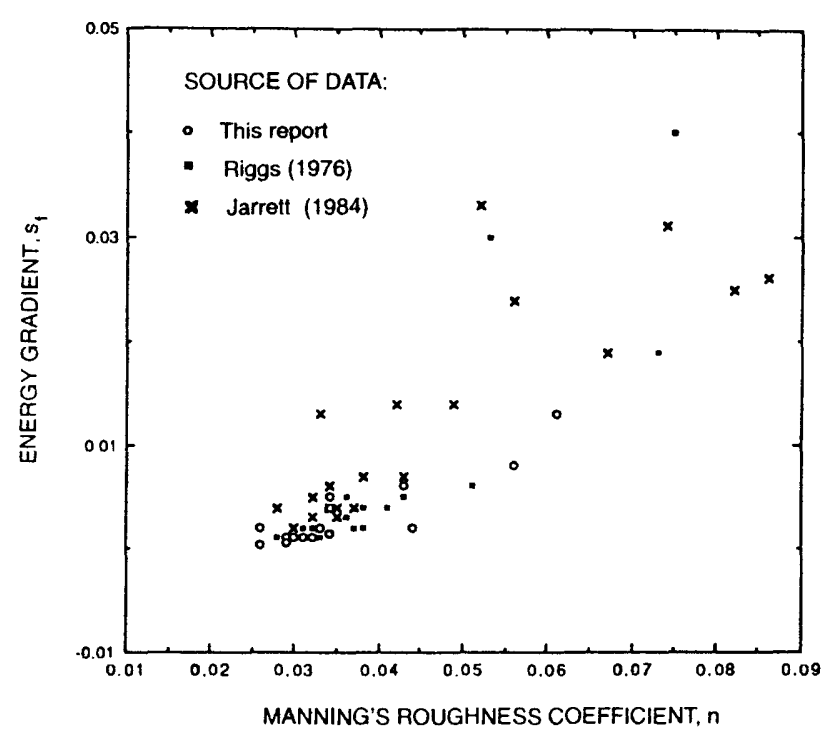

Figure 4. Relation between Manning's roughness coefficient and energy gradient for high within-bank flows. 
ticles for high within-bank flows is shown in figure 5. All other factors remaining constant, the hydraulic roughness of a channel will increase with an increase in bed-particle size.

The intermediate diameters $\mathrm{d}_{50}$ and $\mathrm{d}_{84}$, the minimum diameter $d_{50}$, and a weighted diameter, $d_{w}$, were used to characterize the bed material in each reach and to identify any strong correlations with the roughness coefficient. The particle diameter, $d_{w}$, is based on the intermediate dimension of the particle and is defined by Limerinos (1970) as the sum of the three products obtained by multiplying $d_{84}$ by $0.6, d_{50}$ by 0.3 , and $d_{16}$ by 0.1 . The intermediate diameter $\mathrm{d}_{50}$ is most strongly correlated $(0.76)$ with the roughness coefficient (table 2). The weighted $d_{w}$ values are less than, but closely correlated with, the $d_{84}$ values.

Several researchers (Boyer, 1954; Bathurst, 1978; and Colosimo and others, 1988) have used a ratio of flow depth to a specific particle-size diameter to define relative smoothness for channels with predominantly large-grain bed material. In this study, relative smoothness was computed from the hydraulic radius and each of the above-mentioned particle-size diameters, and the relative smoothness based on the minimum diameter $\mathrm{d}_{50}$ was correlated most highly $(-0.52)$ with the roughness coefficient. When the variables are logarithmically transformed, this correlation improves $(-0.88)$ and is just slightly less than the correlation between the $\log$-transformed $n$ value and the log-transformed rela-

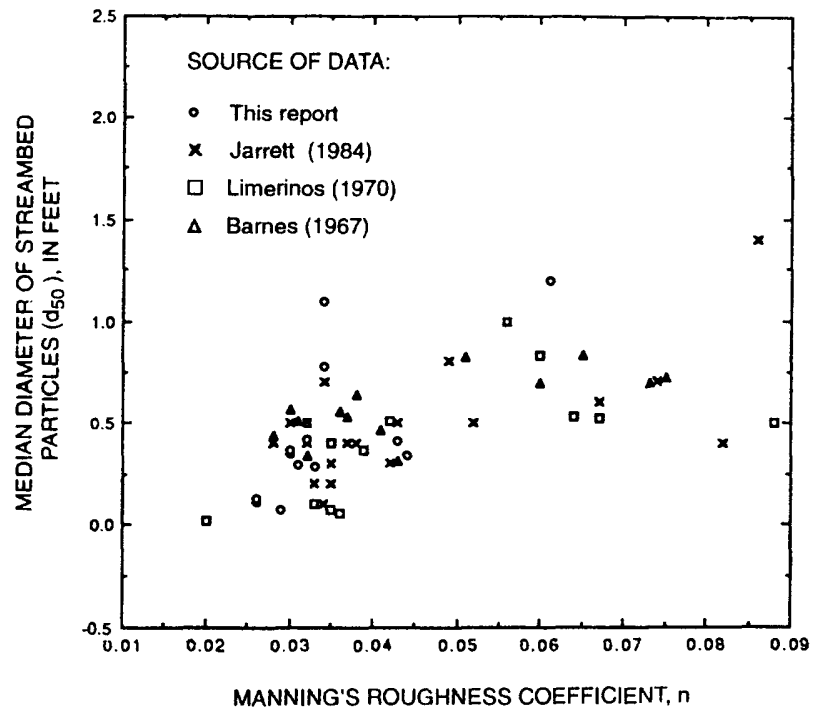

Flgure 5. Relation between Manning's roughness coefficient and streambed particle size (intermediate diameter $d_{50}$ ) for high within-bank flows.

tive smoothness based on the intermediate $d_{84}(-0.89$, table 2). The relations between the roughness coefficient and relative smoothness values based on the intermediate particle-size diameters for wide channels (more than $100 \mathrm{ft}$ wide) and narrow channels with no measurable roughness effect from streambank vegetation are shown in figure 6.

The relation between bed particle-size distribution and the roughness coefficient was checked through
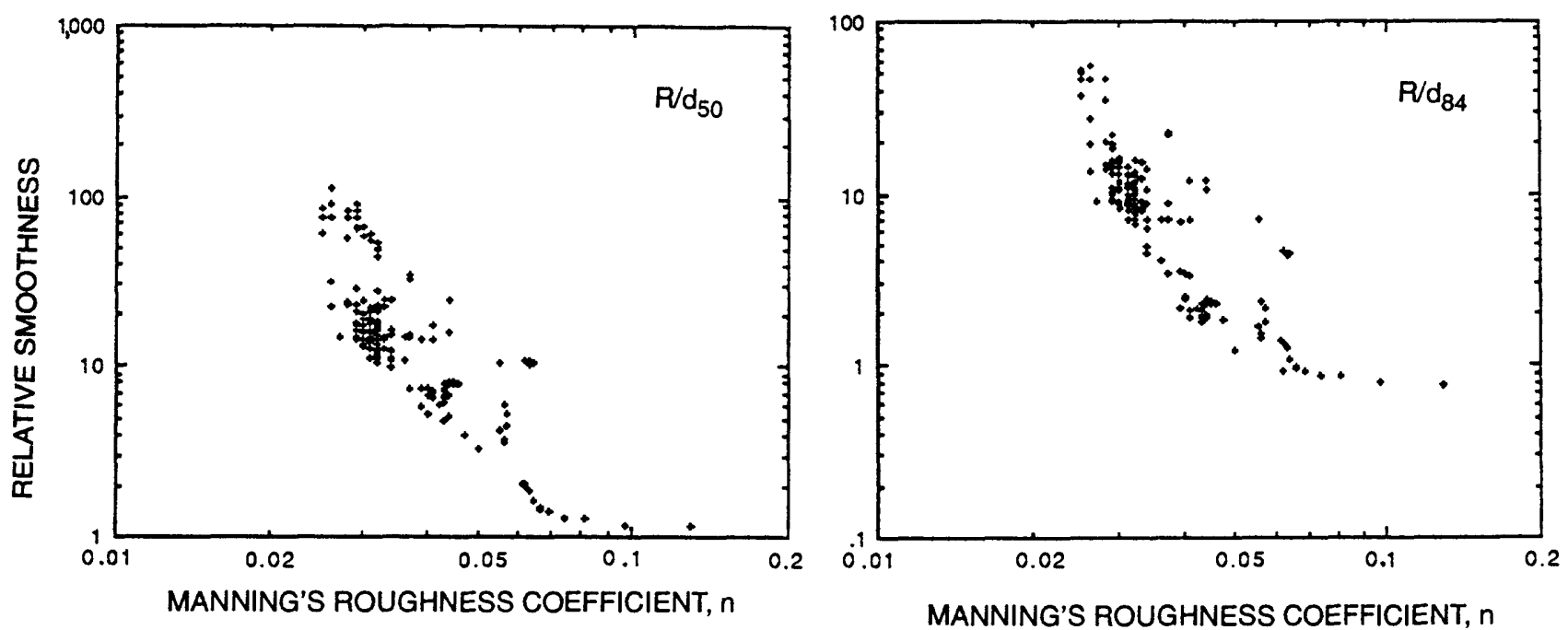

Figure 6. Relations between Manning's roughness coefficient and relative smoothness values, $R / d_{50}$ (left) and R/d $d_{84}$ (right), based on the intermediate particle-size diameters for wide channels (more than $100 \mathrm{ft}$. wide) and narrow channels with no measureable roughness effect from streambank vegetation. 
application of the particle-size data for the intermediate dimension. Two values that characterize the particlesize distribution were computed: $d_{84} / d_{50}$ and $\left(d_{16}+d_{50}\right.$ $\left.+d_{84}\right) / 3\left(d_{50}\right)$. No consistent relation was identifiable between the roughness coefficient and either of these particle-size-distribution values.

\section{Streambank Vegetation}

Vegetation growing within the streambanks, including the low-water channel, retards flow by increasing turbulence and reducing channel capacity. Although reduced channel capacity is not an energy-loss factor, it is often incorporated along with turbulence into the roughness coefficient. Available data on roughnessadjustment values to correct for vegetation (appendix table A1-4, p. 40) are primarily applicable to channels where vegetation is uniformly distributed across a channel section and for channels less than $100 \mathrm{ft}$ wide. Narrower channels generally require larger adjustments for vegetation, and wide channels with no substantial channel-bottom vegetation would require negligible adjustments, if any. Few studies have dealt with the incremental roughness effects of streambank vegetation alone.
Streambank vegetation at the 21 study sites ranged from maintained (mowed) grass to various combinations and densities of trees and brush. Three of the sites had vegetated low-overflow areas, and one had grass growing on a gravel bar over a very small part of its channel bottom. The streambank-vegetation descriptions were categorized as sparse, moderate, and dense, and a vegetation index that represents the type and relative density of streambank vegetation was developed. This index represents the average vegetation conditions of the inundated part of both banks and can change with flow depth and season. A low value (0 to 1$)$ denotes sparse vegetation and minimal flow retardance; a high index (4) signifies dense vegetation and a potentially large effect on the roughness coefficient. The vegetation indices for bankfull flows at the study sites are included in appendix 2 . Table 3, although not all inclusive, describes the vegetation characteristics of the study sites, which are representative of conditions on most streams in northeastern United States.

Data tabulations (table 4) and graphs of hydraulic radius in relation to the roughness coefficient (appendix 2) indicate that bank vegetation has no measurable effect on the roughness coefficient of streams wider than $100 \mathrm{ft}$ and whose wetted perimeter is less than 25 per-

Table 3. Description and index of streambank vegetation of study sites, New York

\begin{tabular}{|c|c|c|}
\hline $\begin{array}{l}\text { Vegetation } \\
\text { index } \\
\text { number }\end{array}$ & $\begin{array}{c}\text { Qualifying } \\
\text { term }\end{array}$ & Description $^{1}$ \\
\hline 0 & Sparse & $\begin{array}{l}\text { All seasons: Short or mowed grass or submerged long grass and soft-stemmed } \\
\text { plants that are bent with the flow. A few scattered trees of any diameter. } \\
\text { Nongrowing season: Also corresponds to vegetation described for index number } 1 \text {. }\end{array}$ \\
\hline 1 & & $\begin{array}{l}\text { Growing season: Rigid grasses and soft-stemmed plants not yet submerged; scat- } \\
\text { tered woody brush, and only a few trees (any diameter) spaced more than } 50 \mathrm{ft} \\
\text { apart. Passage by foot or sighting with surveying equipment unobstructed by } \\
\text { vegetation. }\end{array}$ \\
\hline & & Nongrowing season: Corresponds to vegetation described for index number 2 . \\
\hline 2 & Moderate & $\begin{array}{l}\text { Growing season: Moderately dense woody brush with scattered trees (any diame- } \\
\text { ter) spaced between } 20 \text { to } 50 \mathrm{ft} \text { apart. Grasses and soft-stemmed plants may be } \\
\text { mixed among the brush. Passage by foot or survey sighting occasionally } \\
\text { obstructed by vegetation. }\end{array}$ \\
\hline & & Nongrowing season: Corresponds to vegetation described for index number 3 . \\
\hline 3 & & $\begin{array}{l}\text { Growing season: Similar to vegetation described for index number } 2 \text { but with more } \\
\text { woody brush or a greater density of trees ( } 1 \text { per every } 10 \text { to } 20 \mathrm{ft} \text { ). Large-diam- } \\
\text { eter trees (greater than } 1.5 \mathrm{ft} \text { ) interspersed among smaller diameter trees }(0.5 \text { to } \\
1.0 \mathrm{ft} \text { ). }\end{array}$ \\
\hline 4 & Dense & $\begin{array}{l}\text { All seasons: High density of mixed-diameter trees spaced less than } 5 \mathrm{ft} \text { apart with } \\
\text { dense woody shrubs, willow saplings, and(or) vines. Passage by foot or survey } \\
\text { sighting impossible along banks. }\end{array}$ \\
\hline
\end{tabular}

${ }^{1}$ Descriptions pertain to the general vegetation conditions of the inundated part of the reach. 
cent vegetated. Study sites that meet this criterion have average stream widths that range from about 100 to $429 \mathrm{ft}$, wetted perimeters that are from 0 to 25 percent vegetated, and hydraulic radii that increase by 3.4 to $9.8 \mathrm{ft}$ in the range of flows recorded. That the $\mathrm{n}$ values computed for these sites are nearly constant or decrease with increasing flow depth (fig. 3) indicates that the effect of streambank vegetation on the total $n$ value is undetectable. At study sites whose stream widths are less than $63 \mathrm{ft}$, vegetation (brush, grass, and trees) that covers more than 25 percent of the wetted perimeter cause the computed roughness coefficient to increase by as much as 0.005 during the nongrowing season, and by an additional 0.002 to 0.012 during the growing season (table 4). The largest adjustment values represent reaches with high vegetation density, narrow channels, or low, but greater-than-zero, percentages of vegetation submergence (that is, the ratio of depth of inundation to height of vegetation). The streambank-vegetation adjustment values for one site (East Branch Ausable River at Au Sable Forks), whose top width is about $200 \mathrm{ft}$ and whose wetted perimeter is more than 30 percent vegetated, appear to be from 0.005 to 0.009 . The relation between the percentage of wetted perimeter that is vegetated and the indicated roughness-coefficient adjustment value for streambank vegetation is shown in figure 7 . Overall, the analyses of the channels affected by vegetation indicate that the percentage of wetted perimeter that is vegetated can be used as an indicator of energy losses that are attributable to stream-

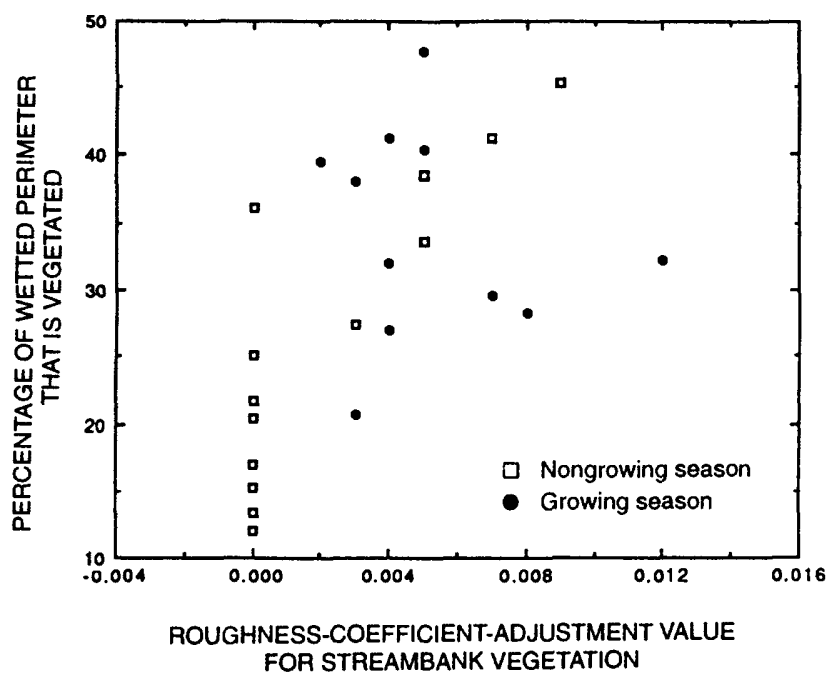

Figure 7. Relation between percentage of wetted perimeter that is vegetated and roughness-coefficientadjustment value for streambank vegetation during nongrowing and growing seasons. bank vegetation. The magnitude of the vegetation effect can be estimated from evaluation of other factors, including energy gradient, stream-top width, season, and type, density, and percent submergence of vegetation. The wide scatter of the data in figure 7 reflects the wide variability of these factors among the study sites.

Details of the analyses of vegetation effects on the roughness coefficients at nine sites are discussed in the following paragraphs. Sites are presented in order of largest to smallest vegetation effect; narrow channels (less than $100 \mathrm{ft}$ wide) are discussed first. Two sites, Onondaga Creek at Dorwin Ave., Syracuse, and Tioughnioga River at Itaska, where streambank vegetation has no apparent effect on the computed roughness coefficient, are included for comparison with the vegetation-affected sites. Data graphs and photographs of each site in appendix 2 can be viewed for clarification of the analyses and channel descriptions given in the text.

Tremper Kill near Andes is vegetated on the right bank with grass, soft-stemmed annual plants, and a few large trees; the left bank is steep and has hemlock trees growing above the level of the highest flow recorded during the study period (fig. A2-1, appendix 2). The average top widths of the channel for the recorded water-surface profiles are from 37 to $53 \mathrm{ft}$, and the wetted perimeters are from 24 to 48 percent vegetated (table A2-1, appendix 2). Streambank vegetation during the nongrowing season had no discernible effect on the computed $\mathrm{n}$ values at this site (fig. 8), probably because the largescale bed material and the irregular left bank with exposed tree roots create major flow impediments that mask the effect of the vegetation on the right bank. Also, as noted in table 2, water-surface slope and energy gradient are strongly correlated with the roughness coefficient. In high-gradient channels such as this one, slope can exert a controlling effect on the $n$ value that obscures the effect of streambank vegetation, at least during the nongrowing season. The summer growth, however, which replaces dead and broken grasses with taller and more resistive plants, has a noticeable effect on the $n$ values (fig. 8). The maximum adjustment to the roughness coefficient for growing conditions $(0.012)$ corresponds to a watersurface elevation just above that of the low-flow channel-the point at which flows encounter resistance from bamboo-like stalks and tufts of grasses. The channel's computed $n$ value for a flow with a hydraulic radius of $1.49 \mathrm{ft}$ during the nongrowing sea- 
Table 4. Incremental effects of streambank vegetation on the roughness coefficient

[Locations are shown in fig. 2. Numbers in parentheses indicate an apparent value. Blank spaces indicate no pertinent data.]

\begin{tabular}{|c|c|c|c|c|c|c|c|c|c|}
\hline $\begin{array}{c}\text { Site } \\
\text { number } \\
\text { and name }\end{array}$ & $\begin{array}{l}\text { Width } \\
\text { (feet) }\end{array}$ & $\begin{array}{l}\text { Hydraulic } \\
\text { radius } \\
\text { (feet) }\end{array}$ & $\begin{array}{l}\text { Energy } \\
\text { gradient }\end{array}$ & $\begin{array}{l}\text { Percent } \\
\text { wetted } \\
\text { perimeter } \\
\text { vegetated }\end{array}$ & $\begin{array}{l}\text { Esti- } \\
\text { mated } \\
\text { base } \\
n \text { value }\end{array}$ & $\begin{array}{l}\text { Non- } \\
\text { growing } \\
\text { season } \\
\text { computed } \\
\text { n value }\end{array}$ & $\begin{array}{l}\text { Growing } \\
\text { season } \\
\text { computed } \\
\text { n value }\end{array}$ & $\begin{array}{c}\text { Adjustme } \\
\text { streambar } \\
\text { Non- } \\
\text { growing } \\
\text { season }\end{array}$ & $\begin{array}{c}\text { values for } \\
\text { vegetation } \\
\text { Growing } \\
\text { season }\end{array}$ \\
\hline \multicolumn{10}{|c|}{$\begin{array}{l}\text { Sites where streambank vegetation has a measurable or apparent } \\
\text { effect on the computed roughness coefficient }\end{array}$} \\
\hline \multirow{6}{*}{$\begin{array}{l}\text { 1. Tremper Kill } \\
\text { near Andes }\end{array}$} & 41.5 & 1.49 & 0.01068 & 32.7 & & 0.054 & & & \\
\hline & 41.0 & 1.40 & .01057 & 31.7 & & & 0.066 & & 0.012 \\
\hline & 47.6 & 2.34 & .01061 & 42.1 & & .054 & & & \\
\hline & 46.3 & 2.21 & .01045 & 40.5 & & & .058 & & .004 \\
\hline & 53.2 & 2.84 & .01205 & 48.2 & & .052 & & & \\
\hline & 52.2 & 2.76 & .01097 & 47.2 & & & .057 & & .005 \\
\hline \multirow{12}{*}{$\begin{array}{l}\text { 2. Scajaquada Creek } \\
\text { at Buffalo }\end{array}$} & 54.2 & 3.02 & .00043 & 27.9 & & .024 & & & \\
\hline & 63.2 & 3.94 & .00055 & 38.5 & & .029 & & .005 & \\
\hline & 50.5 & 2.62 & .00055 & 22.5 & & & .027 & & \\
\hline & 55.6 & 3.16 & .00072 & 29.7 & & & .033 & & .006 \\
\hline & 54.2 & 3.02 & .00043 & 27.9 & & .024 & & & \\
\hline & 54.6 & 3.06 & .00072 & 28.4 & & & .032 & & .008 \\
\hline & 55.2 & 3.13 & .00053 & 29.3 & & .026 & & & \\
\hline & 55.6 & 3.16 & .00072 & 29.7 & & & .033 & & .007 \\
\hline & 57.4 & 3.36 & .00048 & 32.1 & & .026 & & & \\
\hline & 57.3 & 3.35 & .00060 & 31.9 & & & .030 & & .004 \\
\hline & 62.5 & 3.87 & .00055 & 37.7 & & .029 & & & \\
\hline & 60.3 & 3.66 & .00056 & 35.5 & & & .029 & & .000 \\
\hline \multirow{6}{*}{$\begin{array}{l}\text { 3. Moordener Kill } \\
\text { at Castleton-on- } \\
\text { Hudson }\end{array}$} & 38.6 & 1.57 & .00130 & 10.9 & & .031 & & & \\
\hline & 46.6 & 2.63 & .00147 & 27.4 & & .034 & & $(.003)$ & \\
\hline & 42.3 & 2.16 & .00145 & 19.5 & & & .035 & & \\
\hline & 43.5 & 2.33 & .00158 & 21.9 & & .032 & & & .003 \\
\hline & 45.9 & 2.60 & .00166 & 26.5 & & & .038 & & \\
\hline & 46.6 & 2.63 & .00147 & 27.4 & & .034 & & & $(.004)$ \\
\hline \multirow{4}{*}{$\begin{array}{l}\text { 4. Canisteo River } \\
\text { at Arkport }\end{array}$} & 37.4 & 2.78 & .00308 & 36.1 & & .034 & & & \\
\hline & 37.5 & 2.80 & .00301 & 36.2 & & .031 & & .000 & \\
\hline & 38.6 & 2.92 & .00316 & 38.0 & & & .034 & & $(.003) \mathrm{a}$ \\
\hline & 38.8 & 2.95 & .00306 & 38.4 & & & .033 & & $(.002) a$ \\
\hline \multirow{4}{*}{$\begin{array}{l}\text { 5. Mill Brook near } \\
\text { Dunraven }\end{array}$} & 38.1 & 1.14 & .00990 & 0 & & .062 & & & \\
\hline & 43.0 & 1.37 & .01095 & $13.1 \mathrm{~b}$ & & .057 & & .000 & \\
\hline & 43.4 & 1.38 & .01015 & $15.6 \mathrm{~b}$ & & & .069 & & $(.012) \mathrm{a}$, \\
\hline & 62.7 & 3.66 & .01080 & $42.0 \mathrm{~b}$ & & .035 & & $(.000)$ & \\
\hline \multirow{4}{*}{$\begin{array}{l}\text { 6. E. Branch } \\
\text { Ausable River at } \\
\text { Ausable Forks }\end{array}$} & 188 & 3.73 & .00835 & 33.7 & $.051 d$ & .056 & & $(.005)$ & \\
\hline & 209 & 4.18 & .00818 & 40.4 & $.050 \mathrm{~d}$ & & .055 & & $(.005)$ \\
\hline & 213 & 4.42 & .00831 & 41.2 & $.050 \mathrm{~d}$ & .057 & & $(.007)$ & \\
\hline & 230 & 5.85 & .00815 & 45.4 & $.047 \mathrm{~d}$ & .056 & & $(.009)$ & \\
\hline
\end{tabular}


Table 4. Incremental effects of streambank vegetation on the roughness coefficient--continued

\begin{tabular}{|c|c|c|c|c|c|c|c|c|c|}
\hline \multirow[b]{2}{*}{$\begin{array}{c}\text { Site } \\
\text { number } \\
\text { and name }\end{array}$} & \multirow[b]{2}{*}{$\begin{array}{l}\text { Width } \\
\text { (feet) }\end{array}$} & \multirow[b]{2}{*}{$\begin{array}{l}\text { Hydraulic } \\
\text { radius } \\
\text { (feet) }\end{array}$} & \multirow[b]{2}{*}{$\begin{array}{l}\text { Energy } \\
\text { gradient }\end{array}$} & \multirow{2}{*}{$\begin{array}{l}\text { Percent } \\
\text { wetted } \\
\text { perimeter } \\
\text { vegetated }\end{array}$} & \multirow{2}{*}{$\begin{array}{c}\text { Esti- } \\
\text { mated } \\
\text { base } \\
\mathrm{n} \text { value }\end{array}$} & \multirow{2}{*}{$\begin{array}{l}\text { Non- } \\
\text { growing } \\
\text { season } \\
\text { computed } \\
\text { n value } \\
\end{array}$} & \multirow{2}{*}{$\begin{array}{l}\text { Growing } \\
\text { season } \\
\text { computed } \\
\text { n value }\end{array}$} & \multicolumn{2}{|c|}{$\begin{array}{l}\text { Adjustment values for } \\
\text { streambank vegetation }\end{array}$} \\
\hline & & & & & & & & $\begin{array}{l}\text { Non- } \\
\text { growing } \\
\text { season }\end{array}$ & $\begin{array}{l}\text { Growing } \\
\text { season }\end{array}$ \\
\hline \multicolumn{10}{|c|}{$\begin{array}{l}\text { Sites where streambank vegetation has a measurable or apparent } \\
\text { effect on the computed roughness coefficient (continued) }\end{array}$} \\
\hline $\begin{array}{l}\text { 7. Beaver Kill at } \\
\text { Cooks Falls }\end{array}$ & $\begin{array}{l}199 \\
208 \\
209 \\
210 \\
210 \\
222\end{array}$ & $\begin{array}{l}4.11 \\
5.50 \\
5.68 \\
5.81 \\
5.80 \\
8.39\end{array}$ & $\begin{array}{l}.00397 \\
.00432 \\
.00445 \\
.00424 \\
.00428 \\
.00474\end{array}$ & $\begin{array}{c}.5 \mathrm{~b} \\
5.2 \mathrm{~b} \\
5.7 \mathrm{~b} \\
6.1 \mathrm{~b} \\
6.1 \mathrm{~b} \\
11.9\end{array}$ & $\begin{array}{l}.040 \mathrm{e} \\
.036 \mathrm{e} \\
.035 \mathrm{e} \\
.035 \mathrm{e} \\
.035 \mathrm{e}\end{array}$ & $\begin{array}{l}.040 \\
.041 \\
.040 \\
.037 \\
.034\end{array}$ & .039 & $\begin{array}{l}.000 \\
.005 \mathrm{c} \\
.005 \mathrm{c} \\
\\
.002 \mathrm{c} \\
(.000)\end{array}$ & $.004 \mathrm{c}$ \\
\hline \multicolumn{10}{|c|}{$\begin{array}{l}\text { Selected sites where streambank vegetation has no apparent } \\
\text { effect on the computed roughness coefficient }\end{array}$} \\
\hline $\begin{array}{l}\text { 8. Onondaga Creek } \\
\text { at Dorwin Ave., } \\
\text { Syracuse }\end{array}$ & $\begin{array}{l}65.4 \\
85.2\end{array}$ & $\begin{array}{l}1.90 \\
4.10\end{array}$ & $\begin{array}{l}.00152 \\
.00145\end{array}$ & $\begin{array}{c}5.1 \\
27.8 \mathrm{f}\end{array}$ & & $\begin{array}{l}.027 \\
.026\end{array}$ & & .000 & \\
\hline $\begin{array}{l}\text { 9. Tioughnioga } \\
\text { River at Itaska }\end{array}$ & $\begin{array}{l}211 \\
265 \\
272 \\
287\end{array}$ & $\begin{array}{l}1.65 \\
4.23 \\
4.90 \\
6.66\end{array}$ & $\begin{array}{l}.00050 \\
.00108 \\
.00114 \\
.00125\end{array}$ & $\begin{array}{l}0 \\
17.6 \mathrm{~b} \\
19.4 \mathrm{~b} \\
32.5 \mathrm{~b}\end{array}$ & & $\begin{array}{l}.031 \\
.032 \\
.032\end{array}$ & .030 & $\begin{array}{l}(.001) \mathrm{c} \\
(.000)\end{array}$ & \\
\hline $\begin{array}{l}\text { 13. Esopus Creek } \\
\text { at Coldbrook }\end{array}$ & $\begin{array}{l}153 \\
220\end{array}$ & $\begin{array}{r}3.60 \\
13.42\end{array}$ & $\begin{array}{l}.00306 \\
.00437\end{array}$ & $\begin{array}{c}0 \\
21.7\end{array}$ & & $\begin{array}{l}.050 \\
.034\end{array}$ & & $(.000)$ & \\
\hline $\begin{array}{l}\text { 14. E. Branch } \\
\text { Delaware River } \\
\text { at Margaretville }\end{array}$ & $\begin{array}{l}105 \\
129\end{array}$ & $\begin{array}{l}3.08 \\
6.80\end{array}$ & $\begin{array}{l}.00204 \\
.00198\end{array}$ & $\begin{array}{r}.9 \\
20.3\end{array}$ & & $\begin{array}{l}.034 \\
.033\end{array}$ & & $(.000)$ & \\
\hline $\begin{array}{l}\text { 16. Susquehanna } \\
\text { River at Unadilla }\end{array}$ & $\begin{array}{l}190 \\
218\end{array}$ & $\begin{array}{r}5.95 \\
11.50\end{array}$ & $\begin{array}{l}.00043 \\
.00100\end{array}$ & $\begin{array}{r}1.1 \\
15.2\end{array}$ & & $\begin{array}{l}.033 \\
.032\end{array}$ & & $(.000)$ & \\
\hline $\begin{array}{l}\text { 17. Unadilla River } \\
\text { at Rockdale }\end{array}$ & $\begin{array}{l}148 \\
162\end{array}$ & $\begin{array}{l}3.45 \\
9.94\end{array}$ & $\begin{array}{l}.00096 \\
.00106\end{array}$ & $\begin{array}{r}.7 \\
13.4\end{array}$ & & $\begin{array}{l}.034 \\
.029\end{array}$ & & $(.000)$ & \\
\hline $\begin{array}{l}\text { 18. Tioughnioga } \\
\text { River at Cortland }\end{array}$ & $\begin{array}{l}185 \\
217\end{array}$ & $\begin{array}{l}3.11 \\
7.96\end{array}$ & $\begin{array}{l}.00059 \\
.00049\end{array}$ & $\begin{array}{r}.5 \\
17.0\end{array}$ & & $\begin{array}{l}.032 \\
.026\end{array}$ & & $(.000)$ & \\
\hline $\begin{array}{l}\text { 19. Chenango River } \\
\text { near Chenango } \\
\text { Forks }\end{array}$ & $\begin{array}{l}385 \\
429\end{array}$ & $\begin{array}{l}4.27 \\
9.06\end{array}$ & $\begin{array}{l}.00072 \\
.00100\end{array}$ & $\begin{array}{r}1.6 \\
12.0\end{array}$ & & $\begin{array}{l}.032 \\
.030\end{array}$ & & $(.000)$ & \\
\hline $\begin{array}{l}\text { 20. Genesee River } \\
\text { near Mount Morris }\end{array}$ & $\begin{array}{l}136 \\
157\end{array}$ & $\begin{array}{r}6.23 \\
10.05\end{array}$ & $\begin{array}{l}.00046 \\
.00031\end{array}$ & $\begin{array}{l}12.1 \\
25.0\end{array}$ & & $\begin{array}{l}.028 \\
.026\end{array}$ & & $(.000)$ & \\
\hline
\end{tabular}

a This adjustment value is considered an approximation because the large flow-area expansion in the reach introduces uncertainty into the $n$-value calculation.

b This percentage of wetted perimeter that is vegetated includes a low-bank area in addition to the channel-side banks.

c This adjustment value reflects the effect of vegetation covering a low-bank area in addition to the channel-side banks.

d Base $n$ value estimated from equation 19 (Jarrett, 1984).

e Base $n$ value estimated by graphical interpolation.

f The vegetated part of the wetted perimeter at this site is covered by mowed grass, which has no discernible effect on the $\mathrm{n}$ value. 
son is 0.054 , and that for a flow with a similar hydraulic radius ( $1.40 \mathrm{ft}$ ) during the growing season is 0.066 (table 4). The difference between these two values, 0.012 , is attributed to the increased streamflow resistance from the growing-season streambank vegetation. Similarly, the computed roughness coefficient for a flow with a hydraulic radius of $2.84 \mathrm{ft}$ during the nongrowing season is 0.052 , and that for a flow with a hydraulic radius of $2.76 \mathrm{ft}$ during the growing season is 0.057 . The difference, 0.005 , is also attributed to growing-season vegetation. The decrease in the adjustment to the roughness coefficient that is attributed to streambank vegetation as flow depth increases probably reflects the decrease in the energy losses as the vegetation becomes submerged and bends with the flow.
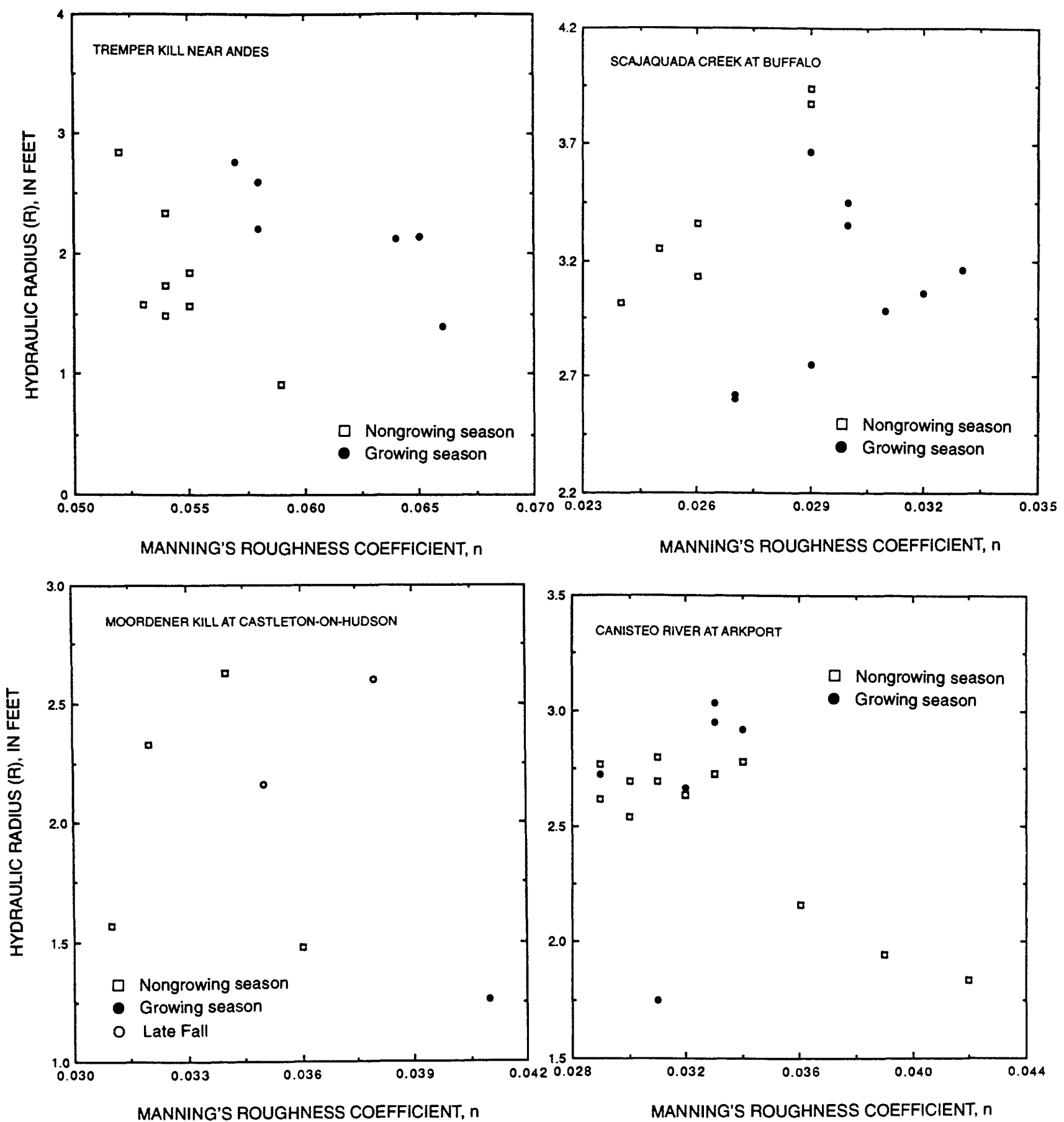

Figure 8. Relation between Manning's roughness coefficient and hydraulic radius as affected by streambank vegetation during the nongrowing and growing seasons at four sites. (Locations are shown in fig.2). 
Scajaquada Creek at Buffalo is a flood-control channel with vetch and grasses along most of its banks (fig. A2-2, appendix 2). The average top widths of the channel for the recorded water-surface profiles range from 50 to $63 \mathrm{ft}$. The wetted perimeters are from 22 to 38 pcrcent vegetated (table A22 , appendix 2). A dense growth of willow saplings and grasses at the low-water edge has a substantial effect on the roughness coefficient. During the nongrowing season, the computed $n$ value increased as water levels rose above the low-water channel and the flow encroached on the vegetation (fig. 8). At the depth at which vegetation was completely submerged and covered about 35 percent of the wetted perimeter of the stream channel, the computed $n$ value ceased to increase and remained constant (0.029) at slightly higher flows. The maximum adjustment to the roughness coefficient for the bank vegetation during the nongrowing season, 0.005 (table 4), is the difference between the minimum and maximum $n$ values computed from data collected during that season. During the growing season, the $\mathrm{n}$ value increased quickly with increasing flow and reached a maximum of 0.033 (fig. 8) when the depth was about three-fourths the height of the vegetation (75-percent submergence). At higher flows, where flexible vegetation bends and thus provides less resistance, the $n$ value decreased until the vegetation was completely submerged, at which point it was the same as for nongrowing conditions. The maximum adjustment to the roughness coefficient for the growing-season vegetation is 0.008 (table 4 ). This is the difference between the growing- and nongrowingseason $n$ values computed for flows with hydraulic radii $(R)$ of $3.06 \mathrm{ft}(n=0.032)$ and $3.02 \mathrm{ft}(\mathrm{n}=0.024)$, respectively; this difference decreases to 0.007 for an average $\mathrm{R}$ of $3.14 \mathrm{ft}$, to 0.004 for an average $\mathrm{R}$ of $3.36 \mathrm{ft}$, and to 0.000 as $\mathrm{R}$ approaches $3.7 \mathrm{ft}$.

Moordener Kill at Castleton-on-Hudson is vegetated with a few 2- to 3-ft-diameter trees and dense brush and vines (fig. A2-3, appendix 2), the summertime density of which is about twice that of the nongrowing season. The average top widths of the channel for the recorded water-surface profiles are from 37 to $47 \mathrm{ft}$, and the percentage of the wetted perimeter that is vegetated ranges from 7 to 27 percent (table A2-3, appendix 2). The computed roughness coefficients appear to be affected by streambank vegetation during the nongrowing season (fig. 8). The channel's computed $n$ value for a flow having a hydraulic radius ( $\mathrm{R})$ of $1.57 \mathrm{ft}$ is 0.031 ; as the depth increases to bankfull $(\mathrm{R}=2.63 \mathrm{ft})$ and the percentage of wetted perimeter of the channel that is vegetated increases from 11 to 27 percent, the computed $n$ value increases to 0.034 (table A2-3, appendix 2). This increase in the roughness coefficient, 0.003 (table 4), is attributed to the increased streamflow resistance as an increasing percentage of flow is impeded by nongrowing-season streambank vegetation. Data for two n-value calculations that were collected during the postgrowing season before snow accumulation appear to reflect the same effect of streambank vegetation as data collected during the growing season. Two comparisons of nongrowingseason n-values with growing-season n-values can be made with these data (table 4). The channel's computed $n$ value for the flow having a hydraulic radius of $2.16 \mathrm{ft}$ during the growing season is 0.035 , and that for a flow having a slightly greater hydraulic radius $(2.33 \mathrm{ft})$ during the nongrowing season is 0.032 . Similarly, the computed $n$ value for a growing-season flow with a hydraulic radius of $2.60 \mathrm{ft}$ is 0.038 , and that for a nongrowing-season flow with a hydraulic radius of $2.63 \mathrm{ft}$ is 0.034 . These differences, 0.003 and 0.004 (table 4), can be attributed to the increased flow resistance from summer growth.

Canisteo River at Arkport is the outflow channel for a reservoir $0.2 \mathrm{mi}$ upstream. Flows in this channel, therefore, are highly regulated. The banks are covered with brush and a few trees that range from 0.5 to $2.0 \mathrm{ft}$ in diameter. The left bank has denser brush than the right bank, and both banks have exposed tree roots (fig. A2-4, appendix 2). The average top widths of this channel for the recorded water-surface profiles range from 30 to $39 \mathrm{ft}$, and the wetted perimeters are from 20 to 40 percent vegetated (table A2-4, appendix 2). Most of the n-value calculations are affected by significant flow-area expansion. Nothing conclusive can be stated as to the effect of streambank vegetation during the nongrowing season, and comparison of growing- with nongrowing-season $n$ values is also inconclusive (fig. 8). For example, the computed $n$ values for a medium flow of $489 \mathrm{ft}^{3} / \mathrm{s}$ during the growing and nongrowing seasons are both 0.032 , whereas two nongrowing-season $n$ values computed for a discharge of $517 \mathrm{ft}^{3} / \mathrm{s}$ differ by 0.003 (table A2-4, appendix 2). At the highest discharges, which show the least effect of flow-area expansion, however, the computed $n$ value increases from 0.031 (for $R=2.80$ 
$\mathrm{ft}$ ) during the nongrowing season to 0.033 or 0.034 (for $\mathrm{R} \approx 2.94 \mathrm{ft}$ ) during the growing season (table 4 ). The lack of an n-value increase for a medium flow during the growing season could be due to an insufficient increase in seasonal vegetation density at medium stages to cause a noticeable increase in the roughness coefficient, whereas at higher flows, this increase in vegetation density has a measurable effect.

Mill Brook near Dunraven has average top widths between 38 and $63 \mathrm{ft}$ (table A2-5, appendix 2 ) and a low overflow area on the left bank that is vegetated by hummocky grasses (fig. A2-5, appendix 2). During the nongrowing season, the grass hummocks have little or no effect, as shown by the decrease in the $n$ value from $0.062(\mathrm{R}=1.14 \mathrm{ft})$ for the low-water channel to $0.057(\mathrm{R}=1.37 \mathrm{ft})$ for a water level that covers most of this vegetation (table 4). This decrease could reflect the trend in the $n$ valueto-depth relation that is expected on this high-gradient channel; as such, the grass hummocks would be considered additional bed-roughness elements of a wider low-water channel. The growing-season effect of this grassy area is shown by the n-value increase to 0.069 for a similar hydraulic radius $(\mathrm{R}=$ $1.38 \mathrm{ft})$. This increase $(0.012$, table 4$)$ is considered an approximation, however, because the large flowarea expansion in the reach introduces uncertainty into the $n-v a l u e$ calculation. The percentage of the wetted perimeter that is vegetated when water covers this area ranges from 13 to 16 percent-less than at most other study sites at which streambank vegetation has some effect on the total roughness coefficient. This descrepancy is probably because the low, grassy area functions more as an extension of the lowwater channel than as a part of the streambank.

Onondaga Creek at Dorwin Avenue, Syracuse is a maintained (mowed) grass-lined flood-control channel with rock rip-rap lining the lower part of the right bank (fig. A2-8, appendix 2). This site is slightly larger than those described previously, and average top widths of the channel for the recorded flows range from 65 to $85 \mathrm{ft}$ (table A2-8, appendix 2). The computed roughness coefficients for this channel, whose wetted perimeters are from 5 to 28 percent vegetated with short grass, do not show any definite effect from streambank vegetation (table 4). This is probably because the cut grass, which has an approximate $n$ value of 0.030 (Chow, 1959, p. 113), is similar to the bed material, whose computed $\mathrm{n}$ values range from 0.026 to 0.029 .

\section{East Branch Ausable River at Au Sable} Forks is about $200 \mathrm{ft}$ wide during high flows and is much larger than the previously discussed sites. It is similar to the other sites, however, in that 30 to 45 percent of its wetted perimeter (depending on the flow depth) is vegetated with dense brush, grass, and trees 0.5 to $1.5 \mathrm{ft}$ in diameter (fig. A2-6, appendix $2)$. The coarse bed material (cobble and boulder), high energy gradient of 0.008 , and low relative smoothness, give large roughness coefficients $(0.056$, table A2-6, appendix 2) that would be expected to decrease with increasing stage. This does not occur, however; the computed $n$ values remain relatively constant with increasing flow depth, probably because the expected decrease in streamflow resistance is offset by the increase in percentage of the wetted perimeter that is affected by vegetation. Jarrett (1984) presents an n-value estimation equation (eq. A-4, appendix 1) for high-gradient, large-bed-material channels that should be applicable to this site. This equation gives $n$-value estimates between 0.051 and 0.047 for the recorded discharges. If the above assumption is correct, then the differences between these estimated $\mathrm{n}$ values and those computed from the field data would indicate n-value adjustments of 0.005 to 0.009 for streambank vegetation at this site (table 4).

Beaver Kill at Cooks Falls is a wide (174 to $222 \mathrm{ft}$ ), high-gradient channel whose data show the expected inverse relation between the roughness coefficient and flow depth (fig. A2-7, appendix 2). The low right bank is densely vegetated with woody brush, willow saplings, and grasses and affects this relation. As flows of 5,000 to $8,000 \mathrm{ft}^{3} / \mathrm{s}$ begin to encroach upon this area, the computed $n$ value stops decreasing. The $\mathrm{n}$ values for flows with hydraulic radii of 4.11 and $5.50 \mathrm{ft}$ are 0.040 and 0.041 , respectively (table 4). As the vegetation becomes submerged and bends, providing less resistance to the flow, the computed $\mathrm{n}$ value decreases quickly from 0.040 at $\mathrm{R}=5.68 \mathrm{ft}$ to 0.039 and 0.037 at $\mathrm{R} \approx 5.80 \mathrm{ft}$. At higher flows, the $n$ value decreases to 0.034 and appears to complete the $\mathrm{n}-\mathrm{to}-\mathrm{R}$ trend indicated by the data from the lower flows. Graphical interpolation between the data extremes allows selection of base $n$ values. The differences between these base $n$ values and the computed values range from 0.002 to 0.005 (table 4) and indicate the increment of roughness that is attributable to the dense vegetation on the low right bank. 
Tioughnioga River at Itaska is another wide channel ( 211 to $287 \mathrm{ft}$ wide) with a wetted perimeter that is more than 25 percent vegetated at high flows, but unlike East Branch Ausable River at Au Sable Forks and Beaver Kill at Cooks Falls, no additional roughness effect from vegetation can be assumed. The computed $n$ values have a low-water value of 0.030 , then alternate between 0.031 and 0.032 at greater flow depths (table A2-9, appendix 2), and are essentially constant through the recorded flow range. Even though the flow passes through a low, vegetated overflow area on the right bank (fig. A2-9, appendix 2 ), no increase in the $n$ value on this low-gradient, cobble channel is discernible during the nongrowing season (table 4). As at Mill Brook near Dunraven, this vegetated overflow area is more an extension of the low-water channel (along with a corresponding change in bed roughness) than a part of the streambank. No data are available from which to identify any additive effect to the roughness coefficient from vegetation during the growing season.

\section{Comparison of Observed with Published Adjustment Values}

Ramser (1929) collected data and computed roughness coefficients for drainage channels before and after dredging or straightening and during growing- and nongrowing-season conditions. Cowan (1956) used Ramser's data to compute roughnesscoefficient adjustment values for five primary factors of energy loss for open-channel flows. The vegetation-adjustment values for the roughness coefficients computed for the study sites (table 4) are generally less than those presented by Cowan (1956). From the descriptions of vegetation given in Cowan's table (table A1-4, appendix 1), adjustment values for the vegetation at the study sites would range from 0.010 to 0.025 during the nongrowing season and from 0.025 to 0.050 during the growing season. In comparison, the indicated adjustments for the vegetation-affected study sites were as high as 0.005 during the nongrowing season and, for the most extreme combination of vegetation conditions, as high as 0.017 during the growing season. This discrepancy is not surprising because the vegetation-affected study channels (excluding East Branch Ausable
River) with widths of 30 to $63 \mathrm{ft}$ are close in size to most of the larger channels whose data were used to calculate Cowan's adjustment values. Also, many of the vegetation conditions described by Cowan apply to the entire cross section of the channel and are not limited to the streambanks alone. Therefore, the most appropriate adjustment values for the study sites would be those close to or less than Cowan's low values. Where possible, new examples of channel conditions for streambank vegetation, based on the results of the data presented in this report, have been included in Cowan's data (table A1-4, appendix 1).

Kayaderosseras Creek near West Milton had higher energy losses than sites with similar hydraulic characteristics and particle sizes (see table A2-10, appendix 2). In addition to bed roughness, this channel has highly irregular banks and changes abruptly from wide, deep, smooth, and semicircular to narrower, shallower, and more irregularly shaped. Trees projecting from the right bank cause erosion upstream and downstream of the projections (fig. A2-10, appendix 2). This scalloping effect, plus exposed tree roots, adds greatly to the energy losses of this $80-\mathrm{ft}$ wide channel. The Cowan (1956) procedure to estimate the $n$ value can approximate the increments of roughness, as quantified by the computed $n$ values, that can be attributed to bank irregularities and to channel-size and -shape variations. A base $n$ value of 0.050 was estimated for this reach of Kayaderosseras Creek from the similarities and differences between the study site and the data presented in table A1-1 (Aldridge and Garrett, 1973) for cobble channels; table A1-2 (Chow, 1959) for "minor mountain streams" with gravel, cobble, and boulders; and Barnes (1967, p. 66 and 186). Both of the sites in Barnes (1967) have more sand and gravel bed material, lower water-surface slopes, and greater depths than Kayaderosseras Creek. If 0.050 is assumed as a reasonable base $n$ value for high within-bank flows at this site (discharges between 1,000 and $1,200 \mathrm{ft}^{3} / \mathrm{s}$ ), and if an adjustment value of 0.001 is applicable for the change in channel size and shape, the remaining increment of roughness (computed by subtracting 0.051 from the computed $n$ values in table A2-10, appendix 2) could be attributed to streambank irregularities. These adjustment values, 0.005 to 0.012 , fall within the range of adjustment values for moderate to severe cross-section irregularities given in table A1-4. 


\section{EVALUATION OF ROUGHNESS-COEFFICIENT EXPLANATORY VARIABLES}

Multiple-regression techniques were used to ascertain the ability of all pertinent variables to explain the variation found in the roughness coefficients. The entire data set, that is, 133 profiles as identified in the section, "Analysis of roughness-coefficient data," was initially used in the following analyses of energy gradient, hydraulic radius, and relative smoothness. Because the study sites include a wide range of hydraulic characteristics that determine the relation between the $\mathrm{n}$ value and flow depth, these data were subsequently divided into hydraulically similar groups on the basis of high and low ranges of several variables. These subsets were reevaluated for their ability to estimate their respective computed roughness coefficients. Only the data from the seven study sites where streambank vegetation had a measurable or apparent effect on the roughness coefficient were used in the analysis of the type and density of vegetation. Finally, several published n-value equations were assessed as to their ability to estimate the $\mathrm{n}$ values calculated for the study sites.

\section{Identiflcation of Pertinent Variables}

The variables most highly correlated with the $\mathrm{n}$ value are energy gradient and relative smoothness (table 2 , log-transformed values). These variables, along with hydraulic radius, are evaluated individually and in combination with each other in the following paragraphs. The type and density of streambank vegetation at the study sites are considered as explanatory variables for the increment of roughness that can be attributed to this flow-retarding factor.

\section{Energy Gradient}

At a significance level of 0.05 , the most statistically significant untransformed variable is energy gradient. This term, which has a high correlation with the $\mathrm{n}$ value $(0.86$, table 2$)$, can explain 74 percent of the observed variability in the roughness coefficients. The close degree of association between these two variables agrees with the results of other researchers (Riggs, 1976; Jarrett, 1984). The relation between the log-transformed values of these variables is similar to that developed by Bray (1979), which is described by equation A-3 (?ppendix 1). This is not surprising because Bray's data are similar to those collected at most of the low- gradient (slopes less than 0.002) study sites. Because Bray's equation (eq.A-3) is based on high within-bank flows on gravel-bed rivers and on a data set that is larger (67 sites) than that compiled in this study, it should yield consistent and reliable estimates of the roughness coefficient for channels with similar hydraulic and particlesize characteristics. No new equation of similar form is presented here.

\section{Hydraulic Radius and Relative Smoothness}

Hydraulic radius, by itself, was not statistically significant (at an 0.05 significance level) in explaining the variability of the roughness coefficients at the study sites because the relation between hydraulic radius and the $\mathrm{n}$ value was inconsistent, as discussed previously in the section, "Relation between Manning's roughness coefficient and selected variables." The log-transformed relative smoothness, $R /$ $\mathrm{d}_{84}$, which was highly correlated with the log-transformed $n$ value $(-0.89$, table 2$)$, can explain 80 percent of the observed variability in the roughness coefficient, however. A regression equation that defines this close degree of association does not appear to be an improvement over Bray's equation (eq. A-3) for estimating roughness coefficients.

\section{Energy Gradient and Relative Smoothness}

The combination of variables that best explains the variation found in the roughness coefficients is the log-transformed values of energy gradient and relative smoothness, $\mathrm{R} / \mathrm{d}_{84}$. Regression analysis indicates that these variables together can explain 81 percent of the observed variability in the $\mathrm{n}$ values. This is not substantially better than the degree of explanation provided by the $\log$-transformed $\mathrm{R} / \mathrm{d}_{84}$ alone, however.

\section{Type and Density of Vegetation}

The collection of n-value data from channels affected by vegetation indicated the possibility of developing an equation to estimate the increment of the total hydraulic roughness that could be attributed to streambank vegetation. In addition to the percentage of wetted perimeter that is covered by vegeta- 
tion, a dummy variable for season $(0=$ dormant and 1 = growing season), and a vegetation-index value that incorporates the type and relative density of streambank vegetation, were considered as explanatory variables. The vegetation-index value ranged from 0 for banks with mowed grass to 4 for banks with dense woody brush, vines, and trees. The vegetation and hydraulic data from the seven sites where streambank vegetation had a measurable or apparent effect on the roughness coefficient (table 4) are too sparse to give all-conclusive results, but the analysis indicates that the percentage of wetted perimeter that is vegetated can be used as an indicator of energy losses that are attributable to streambank vegetation.

\section{Grouping of Data}

The diversity of the data and the apparent inclusion of two or more major categories of n-value-controlling factors led to attempts to further explain the variation found in the roughness coefficients by grouping sites or data with similar characteristics. Two factors that showed either poor or no linear relation to the roughness coefficient were top width of stream and the ratio of hydraulic radius to top width $(\mathrm{R} / \mathrm{T})$. The data from the 133 profiles that were used in the preceding analyses were divided on the basis of high and low ranges in these terms; $100 \mathrm{ft}$ for stream top width and 0.035 for $R / T$ were arbitrarily chosen as the dividing points. The data also were grouped by energy-gradient values with 0.002 as the dividing point. This value was used to separate the data into high-and low-gradient profiles and corresponds with Jarrett's (1984) slope criterion. Finally, in accordance with the relative submergence criteria of Bathurst and others (1981), the data were divided into large- and small-scale roughness categories on the basis of $\mathrm{R} / \mathrm{d}_{84}$ and $\mathrm{R} / \mathrm{d}_{50}$ ratios. Largescale roughness refers to bed material with a particle size the same order of magnitude as the depth of flow. Small-scale roughness refers to bed material of small particle size in relation to the depth of flow. No combination of the above groupings of data yielded an overall improvement in the development of an $n$-value estimation equation derived from data from this study alone.

\section{Assessment of Published Equations}

As mentioned previously, Benson and Dalrymple (1967) state that the n-value relations for channels with an $R / d_{50}$ ratio greater than 5 differ from those for channels with a ratio less than 5. Bathurst (1978) points out that the flow resistance of large-scale roughness, in which the size of the sediment is of the same order of magnitude as the depth of flow, is dependent on the sum of the form drags of the individual roughness elements, whereas the flow resistance of small-scale roughness is described by boundary-layer theory wherein the roughness elements on the streambed function collectively as one surface to apply a frictional shear on the flow. Bathurst and others (1981) summarize past studies that show that flow-resistance processes differ among channels with differing ratios of flow-depth to particle size (depth/ $\left.\mathrm{d}_{50}\right)$ and recommend that a power-law resistance equation be used to estimate $n$ values for channels with large-scale roughness (depth/d $\mathrm{d}_{50}$ less than 2 ), and different semilogarithmic equations be used for channels with small-scale (depth/d $\mathrm{d}_{50}$ greater than 7.5) and intermediate roughness. Griffiths (1981) proposes separate equations for gravel channels with rigid and mobile beds. A channel bed is considered mobile if the product of $36.09 \mathrm{RS}_{\mathrm{w}}$, where $\mathrm{R}=$ hydrauic radius, in feet, and $S_{w}=$ water-surface slope, is greater than the channel's median bed-particle size; otherwise the channel bed is considered rigid. Therefore, no single resistance equation can consistently and accurately estimate $\mathrm{n}$ values for all channels. In addition, researchers who have defined field-based relations between the roughness coefficient and variables such as water-surface slope, energy gradient, bed-particle size, and hydraulic radius (Limerinos, 1970; Bray, 1979; Jarrett, 1984; Griffiths, 1981), were subject to the geographic limitations of their respective research areas or purposely selected sites with ideal channel characteristics. As a result, the application of the equations that have been developed from these and other studies is limited to flows and channels that are similar to those from which the various equations were derived.

Twelve published $n$-value equations were assessed for their ability to estimate the computed $n$ values from the study sites. Though these do not include all n-value equations that have been developed, they are representative of the many forms that have been proposed and include the many relevant and measurable explanatory variables that have been shown by other investigators to explain a large percentage of the stream-to-stream and within-stream variations in the roughness coefficient. The estimative abilities of these equations are indicated in table 5 by (1) the range of differences between the $n$ values computed from the study-site 
Table 5. Differences between $\mathrm{n}$ values computed from study-site data and those estimated from published n-value equations

$[--$, no value presented. $]$

\begin{tabular}{|c|c|c|c|c|}
\hline Investigator & Equation ${ }^{1}$ & $\begin{array}{c}\text { Range of } \\
\text { differences }^{2}\end{array}$ & $\begin{array}{c}\text { Mean } \\
\text { absolute } \\
\text { error }\end{array}$ & $\begin{array}{l}\text { Equation } \\
\text { number }\end{array}$ \\
\hline \multicolumn{5}{|c|}{ GRAVEL- AND(OR) COBBLE-BED CHANNELS ${ }^{3}$} \\
\hline \multirow[t]{3}{*}{ Bray $(1979)^{4}$} & $\mathrm{n}=0.104 \mathrm{~S}_{\mathrm{w}}^{0.177}$ & -0.011 to 0.023 & 0.002 & (8) \\
\hline & $\mathrm{n}=0.048 \mathrm{~d}_{50}^{0.179}$ & -0.012 to 0.027 & 0.007 & (9) \\
\hline & $\mathrm{n}=\frac{0.0927 \mathrm{R}^{1 / 6}}{0.248+2.36 \log \left(\mathrm{R} / \mathrm{d}_{50}\right)}$ & -0.012 to 0.007 & 0.007 & $(10)$ \\
\hline Strickler $(1923)^{5}$ & $\mathrm{n}=0.034 \mathrm{~d}_{50}{ }^{1 / 6}$ & 0.000 to 0.039 & 0.004 & (11) \\
\hline Henderson (1966) & $\mathrm{n}=0.031 \mathrm{~d}_{75}{ }^{1 / 6}$ & 0.000 to 0.039 & 0.005 & $(12)$ \\
\hline \multirow[t]{4}{*}{ Limerinos (1970) } & $\mathrm{n}=\quad 0.0926 \mathrm{R}^{1 / 6}$ & & & \\
\hline & $\overline{1.16+2.0 \log \left(\mathrm{R} / \mathrm{d}_{84}\right)}$ & -0.012 to 0.005 & 0.007 & (13) \\
\hline & $\mathrm{n}=\quad 0.0926 \mathrm{R}^{1 / 6}$ & & & \\
\hline & $\overline{0.35+2.0 \log \left(\mathrm{R} / \mathrm{d}_{50}\right)}$ & -0.016 to 0.002 & 0.010 & (14) \\
\hline Froehlich $(1978)^{4}$ & $\mathrm{n}=0.245 \mathrm{R}^{0.14}\left(\mathrm{R} / \mathrm{d}_{50}\right)^{-0.44}(\mathrm{R} / \mathrm{T})^{0.30}$ & -0.005 to 0.016 & 0.006 & $(15)$ \\
\hline \multirow[t]{3}{*}{ Griffiths $(1981)^{4}$} & $\mathrm{n}=\quad 0.0927 \mathrm{R}^{1 / 6}$ & & & \\
\hline & $\overline{0.760+1.98 \log \left(\mathrm{R} / \mathrm{d}_{50}\right)}$ & -0.011 to 0.012 & 0.007 & (16) \\
\hline & $\mathrm{n}=0.104 \mathrm{R}^{1 / 6}\left(\mathrm{R} / \mathrm{d}_{50}\right)^{-0.297}(\mathrm{R} / \mathrm{P})^{0.103}$ & -0.015 to 0.014 & 0.008 & $(17)$ \\
\hline Sauer $(1990)^{6}$ & $\mathrm{n}=0.11 \mathrm{~S}_{\mathrm{w}}^{0.18} \mathrm{R}^{0.08}$ & -0.016 to 0.020 & 0.005 & $(18)$ \\
\hline \multicolumn{5}{|c|}{ HIGH-GRADIENT CHANNELS ${ }^{7}$} \\
\hline Jarrett (1984) & $\mathrm{n}=0.39 \mathrm{~S}_{\mathrm{f}}^{0.38} \mathrm{R}^{-0.16}$ & -0.007 to 0.062 & 0.008 & (19) \\
\hline \multicolumn{5}{|c|}{ VEGETATED CHANNELS ${ }^{8}$} \\
\hline Bray (1979) & Equation 8 & -0.011 to 0.019 & -- & \\
\hline Strickler (1923) & Equation 11 & 0.001 to 0.034 & -- & \\
\hline Froehlich (1978) & Equation 15 & -0.019 to 0.017 & -- & \\
\hline Sauer (1990) & Equation 18 & -0.016 to 0.016 & -- & \\
\hline
\end{tabular}

1 All length dimensions are in feet. $S_{w}=$ slope of water surface. $T=$ top width of stream.

$P=$ wetted perimeter. Other variables are as previously defined.

2 A negative difference indicates an overestimation of the computed $n$ value by the equation. A positive difference indicates an underestimation.

$396 \mathrm{n}$-value computations from channels with $\mathrm{d}_{84}$ less than $1.0 \mathrm{ft}$.

4 As published in Jobson and Froehlich (1988).

5 As published in Henderson (1966).

6 V. B. Sauer (U.S. Geological Survey, written commun., 1990).

$740 \mathrm{n}$-value computations from channels with friction slope greater than 0.002 .

$840 \mathrm{n}$-value computations from channels with more than 25 percent of their wetted perimeters vegetated. 
data by equation 7 and those estimated by each equation, and (2) the mean absolute error of these differences. The closest $\mathrm{n}$-value estimates for high withinbank flows and their respective equations are given in table 6. High within-bank flows were selected as a way to standardize the comparison of the equations. Results for lower flows in the same channels could be quite different from those for the high flows selected.

No one equation was capable of accurately estimating $\mathrm{n}$ values for all stages on all channels. For the $136 \mathrm{n}$-value calculations that are included in the general analysis of the data, equation 8 (Bray, 1979) gives the closest estimates of the computed $n$ values; the mean absolute crror is 0.002 (table 5). The differences between the computed $\mathrm{n}$ values and those estimated by equation 8 range from -0.011 to 0.023 . Table 6 shows that equation 8 most closely estimates $\mathrm{n}$ values for gravel and small-cobble channels (median particle size 0.06 to $0.5 \mathrm{ft}$ and $\mathrm{R} / \mathrm{d}_{50}$ greater than 5). In addition to equation 8 , equations 11 and 15 (Strickler, 1923 and Froehlich, 1978, respectively) frequently estimated the computed $n$ values for high within-bank flows on cobble channels within 0.002 (table 6). This accuracy is less consistent than that shown by the estimates from equation 8 , however. Equation 11 has a mean absolute error of 0.004 but tends to underestimate the computed $n$ values, as the range in differences $(0.000$ to 0.039$)$ indicates. The range in differences for estimates by equation 15 is smaller $(-0.005$ to 0.016$)$ than those for equations 8 and 11 , but the mean absolute error $(0.006)$ is higher.

The apparent accuracy of Bray's (1979) equation, as indicated by the data presented in table 6 , does not imply that this equation is the best general $n$-value equation for all streams, first because the similarity of more than half of the study sites to those used by Bray (1979) in the development of his equation is coincidental, and second because this equation is limited to high within-bank flows on gravelbed channels. This analysis does indicate that Bray's equation can give reliable n-value estimates for channels with hydraulic characteristics that are similar to those of the sites used in the development of equation 8 , however. Further discussion of this equation is presented in appendix 1.

Equation 19 (Jarrett, 1984) is the only equation that is based on data from high-gradient chan- nels. For the $40 \mathrm{n}$-value calculations for channels in which friction slope exceeds 0.002 and $R / d_{50}$ is less than or only slightly greater than 5 , the mean absolute error for equation 19 is 0.008 . Equations 11 and 12 (Strickler, 1923 and Henderson, 1966, respectively) accurately estimated the computed $n$ values for high within-bank flows at Esopus Creek at Coldbrook and Beaver Kill at Cooks Falls, but these equations cannot reproduce the decrease in the roughness coefficient with increasing flow depth that occurs in this type of channel. The negative exponent on the hydraulic-radius variable of equation $19 \mathrm{en}$ sures an inverse relation between the $n$ value and flow depth.

The flow-retarding effect of streambank vegetation on wide channels with a wetted perimeter that is less than 25 percent vegetated appears to be reasonably quantified in the roughness coefficients estimated by the previously discussed equations. For channels in which vegetation covers more than 25 percent of the wetted perimeter, no single equation estimates the computed $n$ values with consistent accuracy. On narrow channels (less than $50 \mathrm{ft}$ wide) with densely vegetated streambanks, equation 18 (Sauer, V.B., U.S. Geological Survey, written commun., 1990) yielded more accurate $n$ values than any other equation, presumably because it is based on roughness coefficients that include the effect of vegetation as well as other flow-retarding factors. The positive exponent on the hydraulic-radius term of this equation ensures an increasing $n$ value with increasing stage, as expected for densely vegetated narrow streams. This equation cannot account for the variety of vegetation types and densities that are found in stream channels, however, and therefore is not expected to yield consistently accurate n-value estimates. On high-gradient vegetated channels, energy gradient appears to have a greater effect on the roughness coefficient than vegetation. For this type of channel, equation 19 (Jarrett, 1984) is again given preference for estimating $n$ values. The foregoing statements concerning the ability of equations to estimate roughness coefficients for narrow, densely vegetated channels are based on a limited data set and serve only as generalizations and guides; therefore, judgment based on experience is necessary to determine their applicability to a particular situation. 
Table 6. Best estimates of $n$ values computed from the study-site data by selected published equations for high within-bank flows

[Locations are shown in fig. $2 . \mathrm{ft}^{3} / \mathrm{s}=$ cubic feet per second; --, no value presented.]

\begin{tabular}{|c|c|c|c|c|c|c|}
\hline \multirow{2}{*}{$\begin{array}{l}\text { Site number } \\
\text { and name }\end{array}$} & \multirow{2}{*}{$\begin{array}{l}\text { Discharge } \\
\left(\mathrm{ft}^{3} / \mathrm{s}\right)\end{array}$} & \multirow{2}{*}{$\begin{array}{l}\text { Computed } \\
\mathrm{n} \text { value }\end{array}$} & \multicolumn{4}{|c|}{ Two best estimates of computed $n$ values } \\
\hline & & & $\mathrm{n}$ value & Equation $^{1}$ & $\mathrm{n}$ value & Equation $^{1}$ \\
\hline \multicolumn{7}{|c|}{ GRAVEL- AND(OR) COBBLE-BED CHANNELS } \\
\hline 8. Onondaga Creek at Dorwin Ave. & 1,890 & 0.026 & 0.026 & 15 & 0.024 & 11 \\
\hline 9. Tioughnioga River at Itaska & $\begin{array}{l}10,100 \\
10,900\end{array}$ & $\begin{array}{l}0.031 \\
0.032\end{array}$ & $\begin{array}{l}0.032 \\
0.032\end{array}$ & 8 & $\begin{array}{l}0.028 \\
0.028\end{array}$ & 11 \\
\hline 12. Sacandaga River at Stewarts Bridge & 13,300 & 0.044 & 0.042 & 13 & 0.041 & 18 \\
\hline $\begin{array}{l}\text { 14. East Branch Delaware River } \\
\text { at Margaretville }\end{array}$ & $\begin{array}{l}2,860 \\
6,600\end{array}$ & $\begin{array}{l}0.034 \\
0.033\end{array}$ & $\begin{array}{l}0.034 \\
0.033\end{array}$ & 15 & $\begin{array}{l}0.035 \\
0.036\end{array}$ & 8 \\
\hline $\begin{array}{l}\text { 16. Susquehanna River at } \\
\text { Unadilla }\end{array}$ & $\begin{array}{l}14,300 \\
19,000\end{array}$ & $\begin{array}{l}0.034 \\
0.032\end{array}$ & $\begin{array}{l}0.034 \\
0.033\end{array}$ & 15 & $\begin{array}{l}0.033 \\
0.033\end{array}$ & 8 \\
\hline 17. Unadilla River at Rockdale & $\begin{array}{l}4,580 \\
4,660\end{array}$ & $\begin{array}{l}0.029 \\
0.030\end{array}$ & $\begin{array}{l}0.029 \\
0.029\end{array}$ & 11 & $\begin{array}{l}0.030 \\
0.031\end{array}$ & 8 \\
\hline $\begin{array}{l}\text { 18. Tioughnioga River } \\
\text { at Cortland }\end{array}$ & $\begin{array}{l}4,320 \\
5,640\end{array}$ & $\begin{array}{l}0.028 \\
0.029\end{array}$ & $\begin{array}{l}0.029 \\
0.029\end{array}$ & 14 & $\begin{array}{l}0.026 \\
0.028\end{array}$ & 8 \\
\hline $\begin{array}{l}\text { 19. Chenango River near } \\
\text { Chenango Forks }\end{array}$ & $\begin{array}{l}20,100 \\
26,500\end{array}$ & $\begin{array}{l}0.031 \\
0.030\end{array}$ & $\begin{array}{l}0.031 \\
0.031\end{array}$ & 8 & $\begin{array}{l}0.029 \\
0.029\end{array}$ & 11 \\
\hline 20. Genesee River near Mount Morris & $\begin{array}{l}6,930 \\
7,740\end{array}$ & $\begin{array}{l}0.025 \\
0.026\end{array}$ & $\begin{array}{l}0.025 \\
0.025\end{array}$ & 8 & $\begin{array}{l}0.024 \\
0.024\end{array}$ & 11 \\
\hline \multicolumn{7}{|c|}{ HIGH-GRADIENT CHANNELS } \\
\hline 7. Beaver Kill at Cooks Falls & $\begin{array}{l}19,800 \\
23,900\end{array}$ & $\begin{array}{l}0.034 \\
0.034\end{array}$ & $\begin{array}{l}0.033 \\
0.033\end{array}$ & $11 \mathrm{a}$ & $\begin{array}{l}0.037 \\
0.036\end{array}$ & 19 \\
\hline 11. Indian River near Indian Lake & $\begin{array}{l}718 \\
794\end{array}$ & $\begin{array}{l}0.062 \\
0.061\end{array}$ & $\begin{array}{l}0.065 \\
0.065\end{array}$ & 19 & $\begin{array}{l}-- \\
--\end{array}$ & $\begin{array}{l}-- \\
--\end{array}$ \\
\hline 13. Esopus Creek at Coldbrook & $\begin{array}{l}37,400 \\
51,700\end{array}$ & $\begin{array}{l}0.036 \\
0.034\end{array}$ & $\begin{array}{l}0.035 \\
0.035\end{array}$ & $11 \mathrm{a}$ & $\begin{array}{l}0.033 \\
0.033\end{array}$ & 19 \\
\hline 15. Ouleout Creek at East Sidney & $\begin{array}{l}1,450 \\
1,680\end{array}$ & $\begin{array}{l}0.043 \\
0.043\end{array}$ & $\begin{array}{l}0.043 \\
0.043\end{array}$ & 15 & $\begin{array}{l}0.045 \\
0.044\end{array}$ & 16 \\
\hline \multicolumn{7}{|c|}{ VEGETATED CHANNELS } \\
\hline 1. Tremper Kill near Andes & $\begin{array}{r}1,040 \\
* 832\end{array}$ & $\begin{array}{l}0.052 \\
0.057\end{array}$ & $\begin{array}{l}0.054 \\
0.057\end{array}$ & $\begin{array}{l}18 \\
16\end{array}$ & $\begin{array}{l}0.048 \\
0.060\end{array}$ & $\begin{array}{r}8 \\
19\end{array}$ \\
\hline 2. Scajaquada Creek at Buffalo & $\begin{array}{r}759 \\
* 656\end{array}$ & $\begin{array}{l}0.029 \\
0.029\end{array}$ & $\begin{array}{l}0.029 \\
0.029\end{array}$ & $\begin{array}{l}9 \\
9\end{array}$ & $\begin{array}{l}0.030 \\
0.030\end{array}$ & $\begin{array}{l}13 \\
13\end{array}$ \\
\hline $\begin{array}{l}\text { 3. Moordener Kill at } \\
\text { Castleton-on-Hudson }\end{array}$ & $\begin{array}{r}409 \\
* 374\end{array}$ & $\begin{array}{l}0.034 \\
0.038\end{array}$ & $\begin{array}{l}0.033 \\
0.038\end{array}$ & $\begin{array}{r}8 \\
18\end{array}$ & $\begin{array}{l}0.037 \\
0.034\end{array}$ & $\begin{array}{r}18 \\
8\end{array}$ \\
\hline 4. Canisteo River at Arkport & $\begin{array}{r}576 \\
* 671\end{array}$ & $\begin{array}{l}0.031 \\
0.033\end{array}$ & $\begin{array}{l}0.028 \\
0.037\end{array}$ & $\begin{array}{l}11 \\
19\end{array}$ & $\begin{array}{l}0.036 \\
0.037\end{array}$ & $\begin{array}{r}19 \\
8\end{array}$ \\
\hline $\begin{array}{l}\text { 6. East Branch Ausable River } \\
\text { at Au Sable Forks }\end{array}$ & $\begin{array}{l}10,800 \\
* 5,720\end{array}$ & $\begin{array}{l}0.056 \\
0.055\end{array}$ & $\begin{array}{l}0.056 \\
0.057\end{array}$ & $\begin{array}{l}16 \\
17\end{array}$ & $\begin{array}{l}0.053 \\
0.052\end{array}$ & $\begin{array}{l}18 \\
18\end{array}$ \\
\hline
\end{tabular}

1 Equations are given in table 5.

a A second equation (eq. 12), similar in form to equation 11, gives n-value estimates ( 0.036 for Esopus Creek and 0.033 for Beaver Kill) with a similar degree of accuracy.

* Data used for this n-value calculation were collected during the growing season. 


\section{PROCEDURE FOR ESTIMATING ROUGHNESS COEFFICIENTS FOR NATURAL STREAM CHANNELS}

The procedure outlined in this section (modified from Jarrett, 1985) is intended to enable the user to systematically evaluate the factors that affect hydraulic roughness in natural channels with coarsegrained bed material. Experience and sound engineering judgment also are needed to properly evaluate the interaction of factors that affect roughness.

The steps outlined below refer to a single discharge or depth of flow. If $n$ values are to encompass a range of flow depths, the procedure would be repeated for selected depths to account for the changes. A roughness-evaluation form (fig. 9) and photographs of the stream are useful as documentation of streamroughness coefficients. Ideally, the n value would be evaluated by different methods of estimation and then compared with field-selected $n$ values. The steps are:

1. Determine the extent of the reach in which roughness appears uniform and to which roughness coefficients are to apply. If channel roughness is not uniform throughout the reach, $n$ values need to be assigned for average conditions. Use evidence of scour or deposition to determine whether the channel is stable, unstable, or a combination of both. Verify that present conditions are representative of those being considered.

2. Decide whether and where the cross section will be subdivided to provide uniform flow conditions within each section. Subdivide the cross section to obtain basic channel shapes (rectangular, trapezoidal, semicircular, or triangular) and complete or nearly complete wetted perimeters. Generally the section is subdivided by geometry into a channel and left and right overbank areas. The point of subdivision between the main channel and the overbank areas is made at the point where overbank flow first occurs, not at the low-water edge, even on streams where the roughness in the low-water channel differs from that on the banks or is the same in the channel and overbank areas. The overbank areas could require further subdivision to reflect distinct changes in roughness that is uniform along the reach (such as for vegetation). Davidian (1984) presents guidelines for subdivision of a cross section and discusses the errors that result from improper methodology.
3. Define the type and size of bed material in each section of the channel and compute the stream width, hydraulic radius, energy gradient (friction slope) and(or) water-surface slope, and percentage of wetted perimeter that is vegetated. Select an initial roughness coefficient by referring to one or more of methods $a, b$, or $c$, described below. Close agreement of $n$ values obtained by differing methods will add confidence to the accuracy of the chosen value. Certain general relations exist among the above-mentioned variables, and deviations from these relations should be identified. For example, median bed-material size is strongly correlated with slope. Where this relation is weak or absent, as in a low-gradient, bouldery channel, hydraulic judgment must be used to evaluate the effect of this anomaly on the roughness coefficient. In this example, slope would probably have a stronger effect on the $n$ value than particle size; therefore, an $n$ value smaller than one based on particle size alone would be the more appropriate value.

a. Refer to roughness-coefficient values in tables Al-1,Al-2, Al-3, or tables in the referencesmentioned in appendix 1 . Most tabulated values reflect idealized bankfull conditions. Departures from these conditions will require n-value adjustments. Note whether the table values reflect boundary friction from the bed and bank materials alone or include other flow-retarding factors. If a range of roughness coefficients is given, use low n values for wide channels.

b. Compare the channel with photographs given in Ramser (1929), Scobey (1939), Chow (1959), Barnes (1967), Aldridge and Garrett (1973), and those in appendix 2 . Note that the computed or estimated $\mathrm{n}$ values presented therein are site- and flow-specific. Any deviation in depth of flow, width, area, water-surface slope, vegetation type or density, and channel curvature from that in an illustrated site requires evaluation of the differences and appropriate modification of the selected $n$ value. Bankfull roughness coefficients selected for uniform channels with particle-size and hydraulic characteristics similar to those of sites for which $n$ values are published will contain less error and require less adjust- 


\section{ROUGHNESS COEFFICIENT EVALUATION}

Stream and location:

Date:

Reach length:

Reach description:

Width:

Hydraulic radius:

Water-surface slope/energy gradient:

Bed material:

Intermediate diameter $\mathrm{d}_{50}$ :

$d_{84}:$

$\mathrm{R} / \mathrm{d}_{50}:$

Vegetation description:

Percentage of wetted perimcter that is vegetated:

Channel computation of n-value:

Factor

$\underline{\text { Value }}$

Remarks/Reference

Base value $\left(n_{0}\right)$

Cross-section irregularity $\left(\mathrm{n}_{1}\right)$

Channel variation $\left(\mathrm{n}_{2}\right)$

Effects of obstructions $\left(n_{3}\right)$

Channel vegetation $\left(n_{4}\right)$

Degree of meandering $(\mathrm{m})$

$\mathrm{L}_{\mathrm{m}} / \mathrm{L}_{\mathrm{s}}=$

$\mathrm{n}=\left(\mathrm{n}_{0}+\mathrm{n}_{1}+\mathrm{n}_{2}+\mathrm{n}_{3}+\mathrm{n}_{4}\right) \mathrm{m}=$

Overbank n-values:

Subarea

$\underline{\text { Value }}$

$\underline{\text { Remarks }}$

Calculation of composite $\mathrm{n}$ value : weighted by wetted perimeter or area.

Figure 9. Sample roughness-coefficient-evaluation form. (Modified from Jarrett, 1985, fig. 14A.) 
ment than those for sites that do not conform to these criteria.

c. Apply equations A-2 through A-7 (appendix 1). A user of these equations must be aware of the limitations and assumptions that apply to each. (See appendix 1 for details.) Generally, an equation used to estimate roughness coefficients can be reliably applied to a site whose characteristics fall within the range of characteristics of the sites used in the equation's development. The more a site of interest exceeds the limitations or violates the assumptions on which an equation is based, the less reliable will be the results. For such sites, comparison of $\mathbf{n}$ values selected by alternative methods would be advisable.

4. Obtain from table A1-4 in appendix 1 the adjustment factors that apply to the reach. Consider upstream and downstream conditions that could cause disturbance or backwater in the reach being studied. Be certain not to add an adjustment for factors that are already represented in the initially selected $n$ value. (The distinction between a base $n$ value and an initially selected $n$ value is important. A base $n$ value reflects only the roughness due to bed and bank material [see glossary], whereas the initially selected $n$ value could include other roughness-contributing factors.) Chow's (1959) base values (table A 1-1, appendix 1) apply to the smoothest condition possible for a given bed material. The values of Benson and Dalrymple (1967), reproduced in table A 1-1, are for a straight, uniform channel of the indicated material and are closer to actual field values than those of Chow. Aldridge and Garrett (1973) suggest that, if Chow's base values are used, the adjustment values in table A1-4 should be used directly. If base values are taken from Benson and Dalrymple (1967) or computed from equation A-2 (appendix 1) (Limerinos, 1970), the adjustment values should be from onehalf to three-fourths as large as those given in table A1-4. Roughness coefficients that are computed from equations A-3, A-4, and A-5 (appendix 1) (Bray, I979; Jarrett, 1984; Sauer, V.B., U.S. Geological Survey, written commun., 1990, respectively) or selected from a photo-comparison source or obtained from a table of $\mathrm{n}$ values that represent roughness factors such as vegetation, meandering, or irregular channel features, might require little or no adjustment; only a severe channel condition such as described in table A1-4 would require fur- ther adjustment. For this condition, Jarrett (1985) suggests that the adjustment to the $n$ value calculated by equation $\mathrm{A}-4$ be about half the corresponding maximum value in table A1-4. Use equation A-8 (appendix 1) to compute a final roughness coefficient. The value obtained is the overall $n$ value for the channel unless a composite $n$ value needs to be computed (step 5).

5. If roughness is not uniform across the channel or within a subdivided section, a composite $n$ value must be computed. First, an $\mathrm{n}$ value is selected (step 3), adjusted for flow-retarding factors, if necessary (step 4), then is weighted by a channel or flow characteristic. Chow (1959) explains the procedure for calculating a composite $n$ value by weighting the different roughness coefficients by the applicable part of the wetted perimeter of the channel. The sum of the products of roughness coefficient and wetted perimeter for each segment of a channel, divided by the total wetted perimeter, produces a composite $n$ value. Where depth varies considerably or where dense brush occupies a large and distinct segment of the channeI, Aldridge and Garrett (1973) suggest using flow area to weight the different roughness coefficients. A composite $n$ value might not be required, depending on the method used to select an initial $n$ value. If this initial estimate is a true base $n$ value, then a composite $n$ should be computed, but if this initial estimate is obtained by a method that already accounts for the variation in roughness within a channel or subdivided section, the initial $\mathrm{n}$ value is already a composite value and requires no further computation or adjustment.

6. If sand is a major constituent of the bed material, the flow regime must be checked. Reliable n-value estimates are possible only for upper-regime flows. Consult the first section of appendix 1 for references and guidance in estimating $n$ values for such sites.

7. If roughness coefficients for overbank areas must be calculated, refer to Arcement and Schneider (1989), which presents guidelines for selecting $n$ values for densely vegetated natural flood plains; Chow (1959), which presents tabulated $n$ values for natural and agricultural overbank areas; Hejl (1977), which describes a method for determining $\mathrm{n}$ values for flooded urban areas; or Jarrett (1985), which gives explanations and examples of roughness-coefficient selection for each of these overbank conditions. 


\section{SUMMARY AND CONCLUSIONS}

Manning's roughness coefficients are presented for a wide range of discharges and water-surface profiles at 21 sites that are representative of streams in New York State excluding Long Island. Crest-stage gages were used to record water-surface profiles. Sites were selected to meet the following criteria:

1. A USGS streamflow-gaging station with relatively stable stage-to-discharge relation is nearby;

2. Channels are relatively straight and uniform, and overbank flows are absent or minimal;

3. Particle size and size distribution of bed material are the major flow-resisting factors (no sand-bed channels were included in this study); and

4. Channels are relatively free of all other flow-retarding factors except streambank vegetation.

The hydraulic and particle-size data collected at these sites are diverse and do not constitute a single n-value population. On coarse-grained channels, the relation between the computed roughness coefficient and flow depth varied among the sites in a predictable manner, depending on energy gradient, relative smoothness (ratio of hydraulic radius to median streambed-particle size), stream-top width, and channel-vegetation density. On low-gradient, wide channels with large relative smoothness, the computed $n$ values remained relatively constant with increasing flow depth. The $n$ values for most of these sites varied by less than 0.005 from low-flow to bankfull conditions. On high-gradient channels with low relative smoothness, the computed roughness coefficient decreased with increasing depth. Study sites included in this category had $\mathrm{n}$ values that varied by as much as 0.068 , but generally by 0.015 to 0.030 from lowflow to bankfull conditions. On narrow, low-gradient channels with dense streambank vegetation, the $\mathrm{n}$ value is expected to increase with increasing depth at least to the point of vegetation submergence.

The presence of the incremental roughness effect of streambank vegetation can be evaluated by the percentage of wetted perimeter that is vegetated. No measurable effect of bank vegetation is found on channels with widths greater than about $100 \mathrm{ft}$ and wetted perimeters that are less than 25 percent vegetated. For wide channels with wetted perimeters that are 25 to 50 percent vegetated, bank vegetation appears to have a small additive effect on the roughness coefficient. On narrow channels in which the wetted perimeter typically is more than 25 percent vegetated, the effect of streambank vegetation can be substantial. The magnitude of the energy-loss effect of streambank vegetation depends on the season and on the type, density, and percentage of submergence of the vegetation. The energy gradient of a narrow channel can have a controlling effect on the $n$ value that can obscure the effect of streambank vegetation, especially on high-gradient channels during the nongrowing season. Additive $n$-value adjustments for bank vegetation are incorporated into a table of adjustment values for five major flow-retarding factors.

The ability of several published equations to estimate the roughness coefficients computed for the study sites was assessed. The study-site data were divided into hydraulically similar groups that met the limitations of the data set used to develop each equation. No one equation was capable of estimating accurately $n$ values for all stages on all channels. An equation based on water-surface slope alone provides the best estimates of the computed $n$ values for high within-bank flows on low-gradient gravel and small-cobble channels and requires no adjustment for streambank vegetation in wide channels. An equation based on energy gradient and an inverse function of hydraulic radius can duplicate the expected relation between the $n$ value and flow depth on high-gradient channels with large cobble and boulder bed material. For wide channels of this type, the effect of streambank vegetation on the $n$ value appears to be incorporated into the computed value. No equation is consistently accurate in estimating roughness coefficients for densely vegetated narrow channels, primarily because no equation has been specifically developed for this purpose and because the wide diversity of vegetation densities and types among stream channels precludes consistently accurate results from a single equation. 


\section{REFERENCES CITED}

Aldridge, B.N., and Garrctt, J.M., 1973, Roughness coefficients for streams in Arizona: U.S. Geological Survey Open-File Report, 87 p.

Arcement, G.J., Jr., and Schneider, V.R., 1987, Roughness coefficients for densely vegetated flood plains: U.S. Geological Survey WaterResources Investigations Report 83-4247, 62p. 1989 , Guide for selecting Manning's roughness coefficients for natural channels and flood plains: U.S. Geological Survey Water-Supply Paper 2339, $38 \mathrm{p}$.

Barnes, H.H., Jr., 1967, Roughness characteristics of natural channels: U.S. Geological Survey Water-Supply Paper 1849, 213 p.

Bathurst, J.C., 1978, Flow resistance of large-scale roughness: American Society of Civil Engineers, Journal of the Hydraulics Division, v. 104, no. HY12, p. 1587-1602.

Bathurst, J.C., Li, R.M., and Simons, D.B., 1981, Resistance equation for large-scale roughness: American Society of Civil Engineers, Journal of the Hydraulics Division, v. 107, no. HY12, p. 1593-1613.

Benson, M.A., and Dalrymple, Tate, 1967, General field and office procedures for indirect discharge measurements: U.S. Geological Survey Techniques of Water-Resources Investigations, book 3, chap. A1, 30 p.

Boyer, M.C., 1954, Estimating the Manning coefficient from an average bed roughness in open channels: Transactions, American Geophysical Union, v. 35, no. 6, p. 957-961.

Brater, E.F., and King, H.W., 1976, Handbook of hydraulics for the solution of hydraulic engineering problems, 6th edition: New York, McGraw-Hill, 584 p.

Bray, D.I., 1979, Estimating average velocity in gravel-bed rivers: American Society of Civil Engineers, Journal of the Hydraulics Division, v. 105, no. HY9, p. 1103-1122.

Carter, R.W., Einstein, H.A., Hinds, Julian, Powell, R.W., and Silberman, E., 1963, Friction factors in open channels-Progress report of the task force on friction factors in open channels of the Committee on Hydromechanics of the Hydraulic
Division: American Society of Civil Engineers Proceedings, Journal of the Hydraulics Division, v. 89 , no. HY2, pt. 1, p. 97-143.

Chow, V.T., 1959, Open channel hydraulics: New York, McGraw-Hill, 680 p.

Colosimo, Carlo, Copertino, V.A., and Veltri, Massimo, 1988, Friction factor evaluation in gravel-bed rivers: American Society of Civil Engineers, Journal of Hydraulic Engineering, v. 114 , no. 8, p. 861-876.

Cowan, W.L., 1956, Estimating hydraulic roughness coefficients: Agricultural Engineering, v. 37, no. 7, p. 473-475.

Dalrymple, Tate, and Benson, M.A., 1967, Measurement of peak discharge by slope-area method: U.S. Geological Survey Techniques of Water-Resources Investigations, book 3, chap. A2, $12 \mathrm{p}$.

Davidian, Jacob, 1984, Computation of watersurface profiles in open channels: U.S. Geological Survey Techniques of Water-Resources Investigations, book 3, chap. A15, 48 p.

Fasken, G.B., 1963, Guide for selecting roughness coefficient " $n$ " values for channels: Milwaukee, Wis., U.S. Department of Agriculture, Soil Conservation Service, $24 \mathrm{p}$.

French, R.H., 1985, Open-channel hydraulics: New York, N.Y., McGraw-Hill, 706 p.

Froehlich, D. C., 1978, Derivation of n-value equation: U.S. Geological Survey, Bay St. Louis, Miss., unpublished data.

Griffiths, G.A., 1981, Flow resistance in coarse gravel bed rivers: American Society of Civil Engineers, Journal of Hydraulics Division, v.107, no. HY7, p. 899-918.

Hejl, H.R., Jr., 1977, A method for adjusting values of Manning's roughness coefficients for flooded urban areas: U.S. Geological Survey, Journal of Research, v. 5, no. 5, p.541-545.

Henderson, F.M., 1966, Open channel flow: New York, Macmillan, $522 \mathrm{p}$.

Hulsing, Harry, Smith, Winchell, and Cobb, E.D., 1966, Velocity-head coefficients in open channels: U.S. Geological Survey Water-Supply Paper 1869-C, 45 p. 


\section{REFERENCES CITED--continued}

Jarrett, R.D., 1984, Hydraulics of high-gradient streams: American Society of Civil Engineers, Journal of Hydraulic Engineering, v. 110, no. HY11, p. 1519-1539.

1985 , Determination of roughness coefficients for streams in Colorado: U.S. Geological Survey Water-Resources Investigations Report 85-4004, $54 \mathrm{p}$.

1990, Hydrologic and hydraulic research in mountain rivers: Water Resources Bulletin, v. 26, no. 3, p. 419-429.

Jarrett, R.D., and Petsch, H.E., Jr., 1985, Computer program NCALC user's manual--verification of Manning's roughness coefficient in channels: U.S. Geological Survey Water-Resources Investigations Report 85-4317, 27p.

Jobson, H.E., and Froehlich, D.C., 1988, Basic hydraulic principles of open-channel flow: U.S. Geological Survey Open-File Report 88-707, $150 \mathrm{p}$.

Kellerhals, Rolf, and Bray, D.I., 1970, Sampling procedures for coarse fluvial sediment: American Society of Civil Engineers, Hydraulics Division Specialty Conference, Minneapolis, Minn., $31 \mathrm{p}$.

Limerinos, J.T., 1970, Determination of the Manning coefficient from measured bed roughness in natural channels: U.S. Geological Survey Water-Supply Paper 1898-B, 47 p.

Petryk, Sylvester, and Bosmajian, George, III, 1975, Analysis of flow through vegetation: American Society of Civil Engineers Proceedings, Journal of the Hydraulics Division, v.101, no. HY7, p. 871-884.

Ramser, C.E., 1929, Flow of water in drainage channels: U.S. Department of Agriculture, Technical Bulletin No. 129, 101 p.

Rantz, S.E., and others, 1982, Measurement and computation of streamflow-Volume 1. Measurement of stage and discharge: U.S. Geological Survey Water-Supply Paper 2175, 284p.

Ree, W.O., and Crow, F.R., 1977, Friction factors for vegetated waterways of small slope: U.S. Department of Agriculture, Agricultural Research Service, ARS-S-151, 56 p.
Ree, W.O., and Palmer, V.J., 1949, Flow of water in channels protected by vegetative linings: U.S. Department of Agriculture, Soil Conservation Service, Technical Bulletin No. 967, 115 p.

Riggs, H C., 1976, A simplified slope-area method for estimating flood discharges in natural channels: U.S. Geological Survey, Journal of Research, v. 4, no. 3, p. 285-291.

Sargent, R.J., 1979, Variation of Manning's n roughness coefficient with flow in open river channels: Journal of the Institution of Water Engineers and Scientists, v. 33, no. 3, p. 290294.

Scobey, F.C., 1939, Flow of water in irrigation and similar canals: U.S. Department of Agriculture, Technical Bulletin No. 652, 79 p.

Simons, D.B., and Richardson, E.V., 1966, Resistance to flow in alluvial channels: U.S. Geological Survey Professional Paper 422-J, 61 p.

Strickler, A., 1923, Beiträge zur Frage der Ge sch-windigkeits-formel und der Rauhigkeitszahlen für Ströme, Kanäle und geschlossene Leitungen [Some contributions to the problems of the velocity formula and roughness factor for rivers, canals, and closed conduits]: Bem, Switzerland, Mitteilungen des Eidgenössischen Amtes für Wasserwirtschaft, no. 16.

Trieste, D.J., and Jarrett, R.D., 1987, Roughness coefficients of large floods, in James, L.G., and English, M.J., eds., Irrigation and Drainage Division Specialty Conference, "Irrigation Systems for the 21st Century," Portland, Ore., Proceedings: New York, American Society of Civil Engineers, p. 32-40.

U.S. Department of Agriculture, 1955, Engineering Handbook: Hydraulics: U.S. Department of Agriculture, Soil Conservation Service, Section 5.

U.S. Department of Transportation, 1979, Design charts for open-channel flow: U.S. Department of Transportation, Federal Highway Administration, Hydraulic Design Series No. 3.

Wolman, M.G., 1954, A method of sampling coarse river-bed material: American Geophysical Union, Transactions, v. 35, no. 6, p. 951-956. 
Bank, left and right - Reference terms used to specify that bank on one's left and right when facing downstream.

Bedform - Alluvial-channel bottom feature whose form is dependent on bed-material size, flow depth, and flow velocity. Bedforms include ripples, dunes, antidunes, and plane bed.

Conveyance - A measure of the carrying capacity of a channel section, defined by the equation:

$$
\mathrm{K}=(1.486 / \mathrm{n}) \mathrm{A} \mathrm{R}^{2 / 3}
$$

where $\mathrm{K}=$ conveyance, in cubic feet per second;

$\mathrm{n}$ = Manning's roughness coefficient, in feet ${ }^{1 / 6}$;

$\mathrm{A}=$ cross-sectional area of flow, in square feet; and

$\mathrm{R}=$ hydraulic radius, in feet.

Correlation coefficient - A numerical expression of the degree of association between two variables. A positive correlation coefficient indicates that one variable increases as the other increases; a negative correlation coefficient indicates that one variable increases as the other decreases. The value of the correlation coefficient lies between +1.0 and -1.0 ; the closer the correlation value is to +1.0 or -1.0 , the greater the degree of association.

Crest-stage gage - A device for recording the peak water-surface elevation during a flood by means of a cork line that adheres to a 1 -inch-diameter wooden rod placed inside a 2 -inch-diameter metal pipe that has been secured to a tree or pipe post.

Cross-sectional area of flow - The cross-sectional area of the water normal to the direction of flow in a channel.

Degree of meandering - As used with Cowan's (1956) method of roughness-coefficient estimation, the ratio of channel meander length, $\mathrm{L}_{\mathrm{m}}$, to valley or straight-channel length of a reach under consideration, $\mathrm{L}_{\mathrm{s}}$.

Energy gradient - Also referred to as friction slope; energy gradient is the slope of the line that represents the elevation of the total head of flow in an open channel. It is computed as the energy loss due to boundary friction per foot of a channel's length.
Flow regime - A range of flows producing similar bedforms, resistance to flow, and mode of sediment transport. The lower flow regime occurs with low discharges and produces bedforms of ripples, ripples on dunes, or dunes. The upper flow regime occurs with high discharges and produces bedforms of plane bed with sediment moving, standing waves, antidunes, or chutes and pools. Between these two stable regimes is the transition regime, which produces instability in the stage-to-discharge relations and in the typical bedforms.

Froude number - A ratio of inertial forces to gravitational forces, defined by the equation:

$$
\mathrm{F}=\mathrm{V} /(\mathrm{gD} \cos \theta / \propto)^{0.5}
$$

where $\mathrm{F}=$ Froude number,

$\mathrm{V}=$ mean velocity of flow, in feet per second;

$\mathrm{g}=$ gravitational acceleration constant, in feet per second squared;

$D=$ hydraulic or mean depth, in feet;

$\theta=$ angle of the channel slope, in degrees; and

$\propto=$ velocity-head coefficient.

Grain size, coarse and fine - Coarse-grained bed material generally refers to those particles (gravel, cobble, boulder) whose size can be individually measured with a graduated rule or caliper; fine-grained material (sand, silt, clay) is measured by passage through a sieve or by rate of sedimentation. See also particle size.

Hydraulic depth - See mean depth.

Hydraulic radius - The ratio of the stream channel's cross-sectional area to its wetted perimeter in a plane normal to the direction of flow.

Manning's roughness coefficient (n value) - A measure of the frictional resistance exerted by a channel on flow. The $\mathrm{n}$ value can also reflect other energy losses, such as those resulting from unsteady flow, extreme turbulence, and transport of suspended material and debris, that are difficult or impossible to isolate and quantify.

Base $\mathbf{n}$ value - Manning's roughness coefficient that quantifies the minimum roughness of a straight, uniformly shaped channel reach in the natural material involved. This value reflects only the boundary friction from the bed and bank 


\section{GLOSSARY OF TECHNICAL TERMS--continued}

sediments and does not include additive effects from other flow-retarding factors, such as channel-shape variation, obstructions, and vegetation.

Computed $\mathbf{n}$ value - As used in this report, a Manning's roughness coefficient that has been computed from known discharge, channel geometry, and water-surface profile. This $n$ value reflects a stage-specific $n$ value with or without increments of roughness attributable to vegetation, obstructions, and other flow-retarding factors.

Estimated $\mathbf{n}$ value - As used in this report, a Manning's roughness coefficient that has been obtained in one of the following ways: (1) computed from an n-value equation, (2) selected from a published n-value table, or (3) estimated by comparison with photographs of channels for which $n$ values have been computed.

Mean depth - Also referred to as hydraulic depth; mean depth is the stream channel's crosssectional area of flow divided by the top width of the free surface of water.

Particle size - The size of material on the bed of a stream, referenced to a specific diameter (either maximum, intermediate, or minimum) of the measured particles.

$d_{50}$ - The particle diameter that equals or exceeds that of 50 percent of the particles, that is, the median size of the bed material.

$d_{84}$ - The particle diameter that equals or exceeds that of 84 percent of the particles.

Relative smoothness - The ratio of hydraulic radius, $\mathrm{R}$, or mean (or hydraulic) depth, $\mathrm{D}$, to a characteristic particle size of the bed material, such as $\mathrm{d}_{50}$ or $\mathrm{d}_{84}$

Relative submergence - As used by Bathurst and others (1981), has the same meaning as relative smoothness; the ratio of depth to a characteristic element height (particle size) of the bed material.

Scale of roughness, small and large - Small-scale roughness refers to bed material of small particle size in relation to the depth of flow. Large-scale roughness refers to bed material with a particle size the same order of magnitude as the depth of flow. Bathurst and others (1981) have defined the scale of roughness by the ratio of mean depth, $D$, to the median size of the intermediate particle dimension, $d_{s 0}$, the following way: small-scale roughness: $\mathrm{D} / \mathrm{d}_{50}$ greater than 7.5 ; intermediate-scale roughness: $\mathrm{D} / \mathrm{d}_{50}$ from 2 to

7.5 ; and

large-scale roughness: $\mathrm{D} / \mathrm{d}_{50}$ less than 2 .

Slope, friction - See energy gradient.

Slope, water-surface - The slope of the water surface, computed as the change in elevation per foot of a channel's length.

Slope-area method of discharge measurement A computational procedure whereby stream discharge is calculated "on the basis of a uniform-flow equation involving channel characteristics, water-surface profiles, and a roughness or retardation coefficient" (Dalrymple and Benson, 1967).

Stream power - A measure of energy transfer; used in computing the regime of flow in sand channels.

Submergence, percent - The amount that vegetation is submerged at a given flow depth, or the ratio of the depth of inundation to the height of vegetation.

Top width of stream - Width of the free surface of water in a cross-sectional plane normal to the direction of flow in a channel.

Vegetation index - As used in this report, a numerical value that represents the type and relative density of streambank vegetation.

Velocity-head coefficient - A factor used to adjust the velocity head computed from the mean velocity in a channel section to give the true mean kinetic energy of the flow for nonuniform distribution of velocities.

Water-surface profile - A longitudinal plot of the water-surface elevation as a function of the distance downstream through a channel reach.

Wetted perimeter - The length of the line of intersection of the channel's wetted surface with a cross-sectional plane normal to the direction of flow. 


\section{APPENDIX 1}

\section{REVIEW OF RELATED STUDIES AND COMMON METHODS USED TO ESTIMATE MANNING'S ROUGHNESS COEFFICIENT}

This appendix contains five sections. The first discusses roughness coefficients from several published sources and presents base-n values (table A11 ), $n$ values for natural channels (table A1-2), and $n$ values for modified channels (table A1-3). The second part lists sources of photographs of channels for which $\mathrm{n}$ values have been computed. These photographs can be used to select $n$ values for sites with similar hydraulic and channel characteristics. The third part presents six published equations for estimating roughness coefficients (eqs. A-2 through A7) and discusses the conditions for which each is appropriate. The fourth part describes the n-value estimation process presented by Cowan (1956) and includes a table of published roughness-coefficient adjustment values for five major flow-retarding factors (table A1-4). The channel-vegetation section of table A1-4 has been modified to include examples that are based on the results of this study. The fifth part discusses several published studies of the effects of vegetation on the roughness coefficient.

\section{Published Coefficients}

Benson and Dalrymple (1967), Chow (1959), and Bray (1979) present basic roughness coefficients that are based on the median particle size of the bed material that forms the wetted perimeter. Their works give ranges of base values for five natural-channel materials: firm earth, sand, gravel, cobbles, and boulders (table A1-1). The roughness coefficients that are selected for sand-bed channels require additional evaluation. Resistance to flow in sand-bed streams varies greatly and is a function of the velocity of flow, grain size, shear, and other variables. Together these variables determine the bedform that the movable bed material will take for a given discharge. The flows that produce the bedforms are classified as lower regime, transition regime, and upper regime (Simons and Richardson, 1966). The roughness coefficients for the lower and transition regimes are greatly affected by bedform roughness. No reliable method of selecting $\mathrm{n}$ values for these flow conditions has been developed. Roughness coefficients for the upper regime are largely dependent on the particle size and are given in table A1-1. After the hydraulic properties of a channel reach have been computed, the reliability of an $n$ value selected from table A1-1 must be checked by confirming that the flow is in the upper regime. This is done by computing stream power from the equation:

$$
\mathrm{SP}=62 \mathrm{RS}_{\mathrm{w}} \mathrm{V} \text {, }
$$

where $\mathrm{SP}=$ stream power, in foot-pounds per second per square feet;

$62=$ approximate specific weight of water, in pounds per cubic foot;

$\mathrm{R}=$ hydraulic radius, in feet;

$S_{w}=$ slope of water surface, in feet per foot; and

$\mathrm{V}=$ mean velocity of flow, in feet per second.

This value is then plotted on figure A1-1, which shows the relation of stream power and median grain size to the type of flow regime. If the stream-power value plots above the upper line, the bed configuration can be assumed to be in the upper regime. If it plots below this line, a reliable $\mathrm{n}$ value cannot be assigned. Simons and Richardson (1966), Benson and Dalrymple (1967), Aldridge and Garrett (1973), and Jarrett (1985) present further discussion on this topic.

Other tables of roughness coefficients can be found in hydraulic textbooks such as Chow (1959), Henderson (1966), and Brater and King (1976), and in channel-design manuals published by Federal agencies (U.S. Department of Agriculture, 1955, and U.S. Department of Transportation, 1979). Tables A1-2 and A1-3 list values of Manning's roughness coefficient for natural channels and modified channels, respectively.

These tables represent a collection of data from many sources and include laboratory and(or) field computations of roughness coefficients for artificial, lined, excavated, dredged, and natural channels. Much of the tabulated data for natural streams results from several studies by the U.S. Department of Agriculture. For example, Ramser (1929) determined 
Table A1-1. Base values of Manning's roughness coefficient

[Modified from Aldridge and Garrett, 1973, table 1; Dash indicates no value given; >, greater than]

\begin{tabular}{|c|c|c|c|c|c|c|c|}
\hline \multirow{3}{*}{$\begin{array}{c}\text { Channel } \\
\text { type and bed } \\
\text { material }\end{array}$} & \multirow{2}{*}{\multicolumn{3}{|c|}{$\begin{array}{l}\text { Median size or } \\
\text { range of bed material }\end{array}$}} & \multicolumn{4}{|c|}{ Base $n$ value } \\
\hline & & & & \multirow{2}{*}{\multicolumn{2}{|c|}{$\begin{array}{l}\text { Benson and } \\
\text { Dalrymple } \\
(1967)^{1}\end{array}$}} & \multirow{2}{*}{$\begin{array}{c}\text { Chow } \\
(1959)^{2}\end{array}$} & \multirow{2}{*}{$\begin{array}{c}\text { Bray } \\
(1979)\end{array}$} \\
\hline & \multicolumn{2}{|c|}{ Millimeters } & \multirow[t]{2}{*}{ Inches } & & & & \\
\hline \multicolumn{7}{|c|}{ Sand channels (upper-regime flow only): } & \\
\hline & 0.2 & & -- & & 0.012 & -- & -- \\
\hline & .3 & & -- & & .017 & -- & -- \\
\hline & .4 & & -- & & .020 & -. & -- \\
\hline & .5 & & -- & & .022 & -- & -- \\
\hline & .6 & & -. & & .023 & -- & -- \\
\hline & .8 & & -- & & .025 & -. & -- \\
\hline & 1.0 & & -- & & .026 & -. & -- \\
\hline \multicolumn{8}{|l|}{ Stable channels: } \\
\hline Concrete & -- & & -- & 0.012 & -0.018 & 0.011 & -- \\
\hline Rock cut & - & & -- & & -- & .025 & -- \\
\hline Firm earth & $-\cdot$ & & -- & .025 & -.032 & .020 & -- \\
\hline Coarse sand & $1-$ & 0.04 & $-\quad 0.08$ & .026 & -.035 & -- & -- \\
\hline Fine gravel & $4-8$ & 0.16 & - $\quad 0.3$ & & -- & .024 & -- \\
\hline Gravel & $2-64$ & 0.08 & $-\quad 2.5$ & .028 & -.035 & -- & -. \\
\hline \multicolumn{8}{|l|}{ Very coarse } \\
\hline gravel & $32-64$ & 1.3 & $-\quad 2.5$ & &.- & -- & .032 \\
\hline Small cobble & $64-128$ & 2.5 & $-\quad 5.0$ & & -- & -- & .036 \\
\hline Cobble & $64-256$ & 2.5 & -10.1 & .030 & -.050 & -- & .. \\
\hline Boulder & $>256$ & & $>10.1$ & .040 & $-\quad .070$ & -. & -- \\
\hline
\end{tabular}

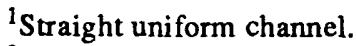

${ }^{2}$ Smoothest channel attainable in indicated material.

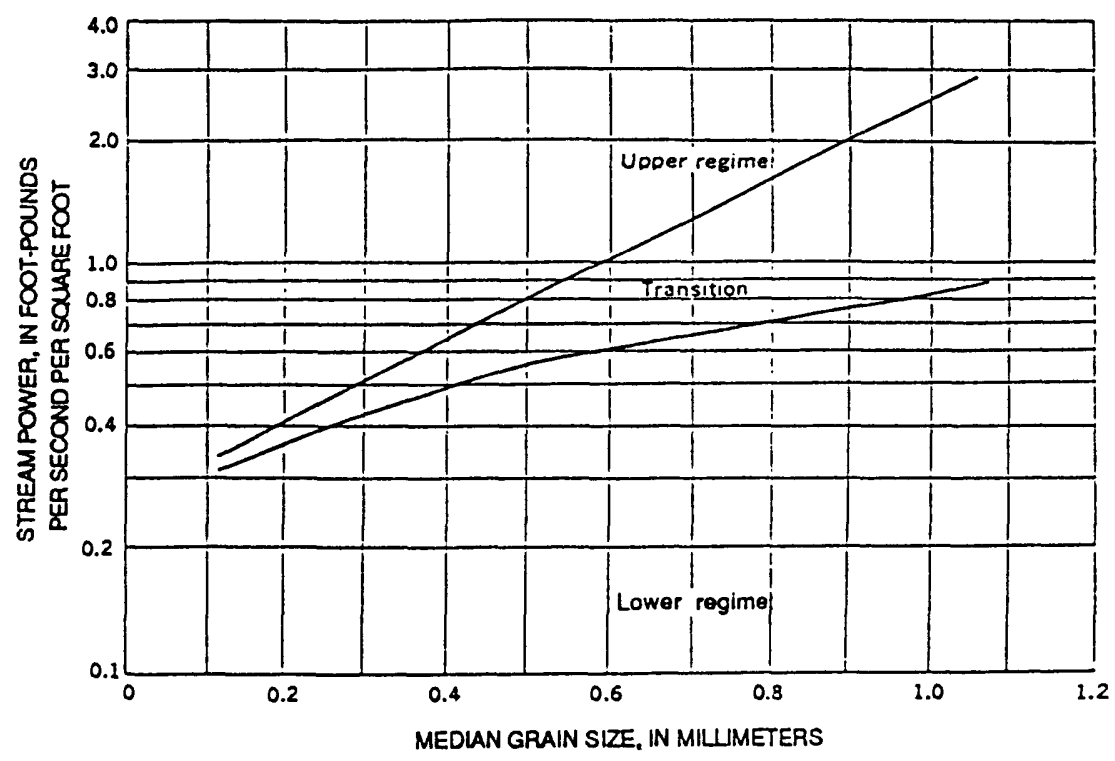

FigureA1-1. Relation of stream power and median grain size to type of flow regime. (Modified from Benson and Dalrymple, 1967, fig. 7.) 
n values for drainage channels; Scobey (1939) for irrigation and similar canals; and Ree and Palmer (1949) for channels protected by vegetative linings. These studies include determinations of $n$ values for given reaches under a range of flow conditions and provide the basis for Cowan's (1956) quantification of the increments of roughness attributable to five of the primary flow-retarding factors. (See "Evaluation of flow-retarding factors" later in this appendix.)

\section{Comparison of Photographs}

The roughness coefficient associated with a given flow can be computed from known discharge, channel geometry, and water-surface elevations. Photographs of channels for which $n$ values have been computed have been published along with particle-size and hydraulic data, and can be used to compare with a site of interest and estimate an n value. Ramser (1929) and Scobey (1939) present photographs of drainage channels and irrigation channels, respectively. Parts of these reports have been reproduced in Chow (1959) and Fasken (1963). Barnes (1967) illustrates 50 channels in color photographs of streams from across the United States that represent a wide range of hydraulic characteristics. Aldridge and Garrett (1973) present photos of 35 channels in Arizona, an arid region where sand is a major constituent of the bed material; computed roughness coefficients are given for 6 of these sites, and estimates by experienced hydrologists are given for the other 29 sites.

\section{Equations}

Researchers have collected detailed data on natural channels for which roughness coefficients have been calculated and have attempted to identify and define by means of equations the relations between flow resistance and hydraulic and particle-size characteristics of stream channels. These equations can then be used to estimate $\mathrm{n}$ values at sites with characteristics similar to those of the sites used in the development of the equations. Six of these equations are presented and described below.

\section{Limerinos (1970)}

Limerinos (1970), using 50 measurements of discharge and data from field surveys at 11 sites in
California, relates the $\mathrm{n}$ value to hydraulic radius and particle size, as follows:

$$
\mathrm{n}=\frac{(0.0926) \mathrm{R}^{1 / 6}}{1.16+2.0 \log \left(\mathrm{R} / \mathrm{d}_{84}\right)}
$$

where $\mathrm{R}=$ hydraulic radius, in feet, and

$\mathrm{d}_{84}=$ intermediate particle diameter, in feet, that equals or exceeds that of 84 percent of the particles.

Limerinos (1970) selected straight reaches that had little increase in width in the downstream direction, were relatively wide and of simple trapezoidal shape, and were relatively free of flow-retarding effects associated with irregular channel features and vegetation. In so doing, he attempted to isolate the effect of bed material on the roughness coefficient. Median bed-material sizes ranged from $0.02 \mathrm{ft}$ (small gravel) to $0.83 \mathrm{ft}$ (cobbles), although the $\mathrm{d}_{50}$ 's at all but one site were less than or equal to $0.53 \mathrm{ft}$. Slopes were mostly less than 0.002 (as reported in Jarrett, 1985), and hydraulic radii were less than $11.0 \mathrm{ft}$. Bray (1979) analyzed many similar equations and concluded that the Limerinos equation (eq. A-2) provides the most reliable estimate of Manning's roughness coefficient for high within-bank flows in gravel-bed channels with small bed-material transport and insignificant channel-bed vegetation.

\section{Bray (1979)}

If bed-material data needed for Limerinos' (1970) equation are unavailable, Bray (1979) presents an alternative equation that relates $n$ to water-surface slope alone:

$$
\mathrm{n}=0.104 \mathrm{~S}_{\mathrm{w}}^{0.177} \text {, }
$$

where $S_{w}=$ slope of water surface.

This equation is based on high within-bank flow data from 67 gravel-bed river reaches in Alberta, Canada, where the intermediate $d_{50}$ ranges from 0.06 to 0.48 $\mathrm{ft}$. Sites that were selected had minimal bed-material transport, no significant vegetation in the channel bed, and no dominant bedform features. Watersurface slopes range from 0.00022 to 0.015 , and channel widths from 47 to $1,790 \mathrm{ft}$. Ratios of mean (or hydraulic) depth to $d_{50}\left(D / d_{50}\right)$ are between 5 and 166 . Benson and Dalrymple (1967) point out that in wide, uniform channels where $\mathrm{D} / \mathrm{d}_{50}$ is between 5 and 276 , 
the roughness coefficient generally is expected to remain relatively constant with changing stage. The absence of a depth term in this equation reflects this conclusion. Therefore, this equation is inappropriate for channels where the $\mathrm{n}$ value is expected to vary with flow depth, such as high-gradient mountain streams and narrow channels with dense streambank vegetation.

\section{Jarrett (1984)}

Jarrett (1984), using 75 measurements of discharge and hydraulic geometry on 21 cobble- and boulder-bed mountain streams in Colorado, relates $\mathrm{n}$ values for high-gradient streams to hydraulic radius and energy gradient, as follows:

$$
\mathrm{n}=0.39 \mathrm{~S}_{\mathrm{f}}{ }^{0.38} \mathrm{R}^{-0.16} \text {, }
$$

where $S_{\mathrm{f}}=$ energy gradient, and

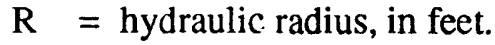

This equation is applicable to channels with energy gradients from 0.002 to 0.09 (Jarrett, 1990) and hydraulic radii from 0.5 to $7 \mathrm{ft}$. Jarrett (U.S. Geological Survey, oral commun., 1990) points out that, for channels in which the hydraulic radius is greater than $7 \mathrm{ft}$, the $\mathrm{n}$ value can be estimated from $\mathrm{R}=7 \mathrm{ft}$ in equation A-4. This indicates that the roughness coefficient is relatively constant for depths of flow in

Table A1-2. Values of Manning's roughness coefficient for natural channels

[Modified from Chow, V. T., 1959, Open channel hydraulics, table 5-6 and published with permission of McGraw-Hill, Inc.]

\begin{tabular}{|c|c|c|c|c|}
\hline & \multirow[b]{2}{*}{ Type of channel and description } & \multicolumn{3}{|c|}{$\mathrm{n}$ value } \\
\hline & & Minimum & Normal & Maximum \\
\hline \multirow[t]{12}{*}{ A. } & $\begin{array}{l}\text { Minor streams (top width at flood stage less } \\
\text { than } 100 \text { feet) } \\
\text { 1. Streams on plain: }\end{array}$ & & & \\
\hline & $\begin{array}{l}\text { a. Clean, straight, full stage, no } \\
\text { rifts or deep pools }\end{array}$ & 0.025 & 0.030 & 0.033 \\
\hline & b. Same as above, but more stones and weeds & .030 & .035 & .040 \\
\hline & c. Clean, winding, some pools and shoals & .033 & .040 & .045 \\
\hline & Same as above, but some weeds and stones & .035 & .045 & .050 \\
\hline & $\begin{array}{l}\text { e. Same as above, lower stages, } \\
\text { more ineffective slopes and sections }\end{array}$ & .040 & .048 & .055 \\
\hline & f. Same as d, but more stones & .045 & .050 & .060 \\
\hline & $\begin{array}{l}\text { g. Sluggish reaches, weedy, deep pools } \\
\text { h. Very weedy reaches, deep pools, or }\end{array}$ & .050 & .070 & .080 \\
\hline & $\begin{array}{l}\text { floodways with heavy stand of } \\
\text { timber and underbrush. }\end{array}$ & .075 & .100 & .150 \\
\hline & $\begin{array}{l}\text { 2. Mountain streams, no vegetation in channel, } \\
\text { banks usually steep, trees and brush } \\
\text { along banks submerged at high stages: }\end{array}$ & & & \\
\hline & a. Bottom: gravel, cobbles, a few boulders & .030 & .040 & .050 \\
\hline & b. Bottom: cobbles with large boulders & .040 & .050 & .070 \\
\hline \multirow[t]{3}{*}{ B. } & $\begin{array}{l}\text { Major streams (top width at flood stage } \\
\text { greater than } 100 \text { feet). The } n \text { value is less } \\
\text { than that for minor streams of similar } \\
\text { description, because banks offer less } \\
\text { effective resistance. }\end{array}$ & & & \\
\hline & 1. Regular section with no boulders or brush & .025 & -- & .060 \\
\hline & 2. Irregular and rough section & .035 & -- & .100 \\
\hline
\end{tabular}


channels where the hydraulic radius exceeds this upper limit. The ratios of hydraulic radius to $d_{50}\left(R / d_{50}\right)$ for the flows recorded at Jarrett's (1984) study sites were mostly less than 5 . Roughness coefficients in uniform channels where this criterion is met are expected to decrease with increasing stage (Benson and Dalrymple, 1967). The negative exponent on the $R$ value in this equation implies this inverse relation. Additional adjustments to an $\mathrm{n}$ value computed by this equation are required for only extreme channel conditions as described in table A1-4 (Jarrett, 1985).

\section{Sauer (1990)}

Channel roughness and water-surface slope are closely correlated. Riggs (1976) used this relation to develop an equation that estimates discharge from only two variables in natural channels: flow area and slope. V. B. Sauer (U.S. Geological Survey, written commun., 1990), in an attempt to generate an n-value equation similar in form to that of Jarrett (1984), derived the following formula from Riggs's (1976) equation:

Table A1-3. Values of Manning's roughness coefficient for modified channels

[From Jarrett, 1985, table 5.]

\begin{tabular}{|c|c|c|c|}
\hline \multirow[b]{2}{*}{ Type of channel and description } & \multicolumn{3}{|c|}{$\mathrm{n}$ value } \\
\hline & Minimum & Normal & Maximum \\
\hline $\begin{array}{l}\text { A. Lined or built-up channels } \\
\text { 1. Concrete: } \\
\text { a. Finished } \\
\text { b. Unfinished }\end{array}$ & $\begin{array}{r}0.011 \\
.014\end{array}$ & $\begin{array}{r}0.015 \\
.017\end{array}$ & $\begin{array}{r}0.016 \\
.020\end{array}$ \\
\hline $\begin{array}{l}\text { 2. Gravel bottom with sides of: } \\
\text { a. Formed concrete } \\
\text { b. Random stone in mortar } \\
\text { c. Dry rubble or riprap }\end{array}$ & $\begin{array}{l}.017 \\
.020 \\
.023\end{array}$ & $\begin{array}{l}.020 \\
.023 \\
.033\end{array}$ & $\begin{array}{l}.025 \\
.026 \\
.036\end{array}$ \\
\hline 3. Vegetal lining & .030 & -- & .500 \\
\hline $\begin{array}{l}\text { B. Excavated or dredged channels } \\
\text { 1. Earth, straight and uniform: } \\
\text { a. Clean, after weathering } \\
\text { b. Gravel, uniform section, clean } \\
\text { c. With short grass, few weeds }\end{array}$ & $\begin{array}{l}.018 \\
.022 \\
.022\end{array}$ & $\begin{array}{l}.022 \\
.025 \\
.027\end{array}$ & $\begin{array}{l}.025 \\
.030 \\
.033\end{array}$ \\
\hline $\begin{array}{l}\text { 2. Earth, winding and sluggish: } \\
\text { a. No vegetation } \\
\text { b. Grass, some weeds } \\
\text { c. Dense weeds or aquatic plants } \\
\text { in deep channels } \\
\text { d. Earth bottom and rubble sides } \\
\text { e. Stony bottom and weedy banks } \\
\text { f. Cobble bottom and clean sides }\end{array}$ & $\begin{array}{l}.023 \\
.025 \\
\\
.030 \\
.028 \\
.025 \\
.030\end{array}$ & $\begin{array}{l}.025 \\
.030 \\
\\
.035 \\
.030 \\
.035 \\
.040\end{array}$ & $\begin{array}{l}.030 \\
.033 \\
.040 \\
.035 \\
.040 \\
.050\end{array}$ \\
\hline $\begin{array}{l}\text { 3. Drag-line excavated or dredged: } \\
\text { a. No vegetation } \\
\text { b. Sparse brush on banks }\end{array}$ & $\begin{array}{l}.025 \\
.035\end{array}$ & $\begin{array}{l}.028 \\
.050\end{array}$ & $\begin{array}{l}.033 \\
.060\end{array}$ \\
\hline $\begin{array}{l}\text { 4. Rock cuts: } \\
\text { a. Smooth and uniform } \\
\text { b. Jagged and irregular }\end{array}$ & $\begin{array}{l}.025 \\
.035\end{array}$ & $\begin{array}{l}.035 \\
.040\end{array}$ & $\begin{array}{l}.040 \\
.050\end{array}$ \\
\hline $\begin{array}{l}\text { 5. Channels not maintained, weeds and } \\
\text { brush uncut: } \\
\text { a. Dense weeds, high as depth of flow } \\
\text { b. Clean bottom, brush on sides } \\
\text { c. Dense brush, high stage }\end{array}$ & $\begin{array}{l}.050 \\
.040 \\
.080\end{array}$ & $\begin{array}{l}.080 \\
.050 \\
.100\end{array}$ & $\begin{array}{l}.120 \\
.080 \\
.140\end{array}$ \\
\hline
\end{tabular}




$$
\mathrm{n}=0.11 \mathrm{~S}_{\mathrm{w}}^{0.18} \mathrm{R}^{0.08},
$$

where $\begin{aligned} \mathrm{S}_{\mathrm{w}} & =\text { slope of water surface, and } \\ \mathrm{R} & =\text { hydraulic radius, in feet. }\end{aligned}$

This equation is based on data from Barnes (1967) and is applicable to channels with water-surface slopes between 0.0003 and 0.018 and with hydraulic radii up to $19 \mathrm{ft}$. Besides incorporating a wide range of hydraulic characteristics, this equation includes the roughness effects, not only from bed and bank material, but also from other flow-resisting factors, including cross-sectional irregularities, variations in channel size and shape, and various vegetated bank conditions. Therefore, roughness coefficients estimated by this equation would not be considered base $\mathrm{n}$ values. In fact, this equation would tend to overestimate base $n$ values and would likely give reasonable estimates for channels whose $n$ values are significantly affected by additional flow-retarding factors. This equation could not be used in a general manner, but is limited to specific applications, such as estimating $n$ values on narrow channels with dense streambank vegetation. In such cases, the $n$ value would be expected to increase with increasing stage, which is the relation implied by the positive exponent on the $R$ value in this equation. Additional adjustments to an $n$ value computed by this equation would probably be required for only extreme channel conditions, as described in table A1-4.

\section{Other Equations}

Two other equations produced fairly accurate estimates of the computed roughness coefficients at some of the study sites. Their estimative abilities were inconsistent, however, because they failed to estimate with the same degree of accuracy $n$ values at other sites with similar hydraulic and particle-size characteristics. Both equations-one developed by Strickler (1923); the other by Froehlich (1978)-are presented here.

Researchers disagree as to whether Strickler's (1923) experiments were conducted on sand-coated flumes or gravel-bed natural channels (French, 1985). Hence, different interpretations of his work have produced different $n$-value equations. Henderson (1966) presents the following equation that is attributed to Strickler (1923):

$$
\mathrm{n}=0.034 \mathrm{~d}_{50}{ }^{1 / 6} \text {, }
$$

where $d_{50}=$ the median size of the bed material, in feet.
Henderson (1966) claims that equation A-6 is based on data that were collected on streams with gravel beds. This equation estimates the $n$ value independently of stage and is appropriate only for relatively high within-bank flows.

Froehlich (1978) developed an equation that relates the roughness coefficient to hydraulic radius, relative smoothness, and a depth-to-width factor. This equation, presented in Jobson and Froehlich (1988), is as follows:

$$
\begin{aligned}
& \mathrm{n}=0.245 \mathrm{R}^{0.14}\left(\mathrm{R} / \mathrm{d}_{50}\right)^{-0.44}(\mathrm{R} / \mathrm{T})^{0.30} \text {, } \\
& \text { where } \mathrm{R}=\text { hydraulic radius, in feet, } \\
& \mathrm{d}_{50}=\text { intermediate particle diameter, in } \\
& \text { feet, that equals or exceeds thatof } \\
& 50 \text { percent of the particles, and } \\
& \mathrm{T}=\text { top width of stream, in feet. }
\end{aligned}
$$

Equation A-7 is based on the diverse data from 15 sites, described in Barnes (1967), for which bed-material particle sizes are included (D. C. Froehlich, University of Kentucky, Dept. of Civil Engineering, oral commun., 1990), and therefore is subject to the same limitations as equation A-5.

\section{Evaluation of Flow-Retarding Factors}

Roughness-coefficient tables, photographic comparisons, and previously cited equations provide a beginning point for evaluating channel-energy losses and estimating $\mathrm{n}$ values. Roughness coefficients obtained by these methods may or may not reflect energy losses that result from factors other than particle size and size distribution of bed material, that is, a base $n$ value. If the initially selected $n$ value does not represent all major roughness factors, it needs to be adjusted. Cowan (1956) provides guidelines for adjusting an $n$ value for additional flow-retarding factors. The general approach is to (1) select a base $n$ value for a straight, uniform, smooth channel in the natural materials of the streambed and banks; (2) add modifying values for channel-surface irregularity, channel-shape variation, obstructions, and type and density of vegetation; and (3) multiply the sum of these values by an adjustment factor for the degree of channel meandering (table A1-4), as represented by the equation

$$
n=\left(n_{0}+n_{1}+n_{2}+n_{3}+n_{4}\right) m,
$$

where $n_{0}=$ base value for a straight, uniform channel; 


$$
\begin{aligned}
& \mathrm{n}_{1}=\text { additive value to account for effect } \\
& \text { of cross-section irregularity; } \\
& \mathrm{n}_{2}=\text { additive value to account for varia- } \\
& \text { tions in size and shape of channel; } \\
& \mathrm{n}_{3}=\text { additive value to account for effect } \\
& \text { of obstructions; } \\
& \mathrm{n}_{4}=\text { additive value to account for type } \\
& \text { and density of vegetation; and } \\
& \mathrm{m}=\text { adjustment factor for the degree of } \\
& \text { channel meandering; determined by } \\
& \text { the ratio of channel meander length } \\
& \left(\mathrm{L}_{\mathrm{m}}\right) \text { to valley or straight-channel } \\
& \text { length }\left(\mathrm{L}_{\mathrm{s}}\right) \text {. }
\end{aligned}
$$

Experienced hydrologists and engineers can include adjustments for other factors as well. Caution must be exercised to ensure that a modifying value for one factor is neither duplicated by the effect of a second factor nor already incorporated in the initially selected $\mathrm{n}$ value. Cowan (1956) did not consider highly unstable sand channels in the development of this procedure. The modifying values for the various factors were developed from a study of 40 to 50 small- to medium-size channels with top widths mostly less than $60 \mathrm{ft}$. Therefore, use of these values is questionable for large channels in which the hydraulic radius exceeds $15 \mathrm{ft}$. When applicable, large adjustments generally are required for narrow channels. As for the vegetation-adjustment values, many of the channel-vegetation examples in table A1-4 describe conditions for vegetation that is distributed uniformly across the entire section and not limited to the streambanks alone. Therefore, use of these values for channels with unvegetated bottoms could be excessive or unnecessary. This approach, described by Chow (1959) and Benson and Dalrymple (1967), is promoted in $\mathrm{n}$ value-estimation reports by Aldridge and Garrett (1973), Arcement and Schneider (1989), and Jarrett (1985).

\section{Considerations for Areas Affected by Vegetation}

Many studies of roughness coefficients address the incremental contribution of vegetation in the channel or flood plain to the total hydraulic roughness. Most of these were laboratory experiments that simu- lated the resistance of vegetation to open-channel flow over large, rigid roughness features in flumes. Carter and others (1963) list the studies conducted through 1960. Additional references since 1960 are noted in Arcement and Schneider's (1987) comparison report on four approaches to evaluate vegetationaffected roughness coefficients. Although these studies have provided much information, direct application of the results to actual streams is limited by the complexities of natural channels or by the absence of field confirmation of laboratory results.

Other researchers, such as Ramser (1929), Ree and Palmer (1949), Ree and Crow (1977), Petryk and Bosmajian (1975), and Arcement and Schneider (1989), in conducting vegetation experiments on natural channels and overbank areas, have dealt with extremely dense vegetation within low-water channels or with vegetated flood plains. None since Ramser (1929), excluding the quantification of vegetationaffected increments of $n$ values from Ramser's data by Cowan (1956), and the indirect inclusion of vegetation effects in the equation of Sauer (U.S. Geological Survey, Atlanta, Ga., written commun., 1990), has conducted any field-based study on the incremental effect that streambank vegetation alone has on the total roughness coefficient. Of the flow-resisting factors analyzed by Cowan (1956), channel vegetation has the largest adjustment values and thus probably has the greatest potential effect on the total roughness coefficient selected for a reach. Adjustments of $\mathrm{n}$ values (table $\mathrm{A} 1-4$ ) as high as 0.100 are suggested for "very large" vegetation conditions. These adjustments are limited in their applicability, however, as discussed in the preceding section, "Evaluation of flow-resisting factors," and should not be used without consideration of the relative size of the channel. Arcement and Schneider $(1989$, p. 8) point out that (1) flow in wide channels having small depth-to-width ratios and no vegetation on the bed is minimally affected by bank vegetation, and the maximum adjustment is about 0.005 ; (2) flow in channels that are relatively narrow and have steep banks covered by dense vegetation that hangs over the channel can be significantly affected, and the maximum adjustment is about 0.03; and (3) the larger adjustment values given in table A 1-4 apply only in places where vegetation covers most of the channel. 
Table A1-4.--Adjustment factors for the calculation of channel $n$ values ${ }^{1}$ [Modified from Jarrett (1985), table 1.]

\begin{tabular}{|c|c|c|c|}
\hline \multicolumn{2}{|c|}{ Channel conditions } & \multirow{2}{*}{$\begin{array}{c}\begin{array}{c}\text { n-value } \\
\text { adjustment }^{2}\end{array} \\
0.000\end{array}$} & \multirow{2}{*}{$\begin{array}{l}\text { Example } \\
\text { o the smoothest channel attainable in a given } \\
\text { erial. }\end{array}$} \\
\hline $\begin{array}{l}\text { Cross-section } \\
\text { irregular- }\end{array}$ & Smooth & & \\
\hline & Minor & $0.001-0.005$ & $\begin{array}{l}\text { Compares to carefully dredged channels in good condition } \\
\text { but having slightly eroded or scoured side slopes. }\end{array}$ \\
\hline & Moderate & $0.006-0.010$ & $\begin{array}{l}\text { Compares to dredged channels having moderate to considerable } \\
\text { bed roughness and moderately sloughed or eroded side slopes. }\end{array}$ \\
\hline & Severe & $0.011-0.020$ & $\begin{array}{l}\text { Badly sloughed or scalloped banks of natural streams; badly } \\
\text { eroded or sloughed sides of canals or drainage channels; } \\
\text { unshaped, jagged, and irregular surfaces in channels in rock }\end{array}$ \\
\hline \multirow{3}{*}{$\begin{array}{l}\text { Channel varia- } \\
\text { tions, } \mathbf{n}_{2} \text {. } \\
\text { (Do not } \\
\text { reevaluate } \\
\text { channel } \\
\text { variation } \\
\text { in the } \\
\text { hydraulic } \\
\text { computa- } \\
\text { tions.) }\end{array}$} & Gradual & 0.000 & Size and shape of channel cross sections change gradually. \\
\hline & $\begin{array}{l}\text { Alternating } \\
\text { occasionally }\end{array}$ & $0.001-0.005$ & $\begin{array}{l}\text { Large and small cross sections alternate occasionally, or the } \\
\text { main flow occasionally shifts from side to side owing to } \\
\text { changes in cross-sectional shape. }\end{array}$ \\
\hline & $\begin{array}{l}\text { Alternating } \\
\text { frequently }\end{array}$ & $0.010-0.015$ & $\begin{array}{l}\text { Large and small cross sections alternate frequently, or the } \\
\text { main flow frequently shifts from side to side owing to } \\
\text { changes in cross-sectional shape }\end{array}$ \\
\hline \multirow[t]{4}{*}{$\begin{array}{l}\text { Effect of } \\
\text { obstruc- } \\
\text { tions, } n_{3}\end{array}$} & Negligible & $0.000-0.004$ & $\begin{array}{l}\text { A few scattered obstructions, which include debris deposits, } \\
\text { stumps, exposed roots, logs, piers, or isolated boulders, } \\
\text { that occupy less than } 5 \text { percent of the cross-sectional area. }\end{array}$ \\
\hline & Minor & $0.005-0.015$ & $\begin{array}{l}\text { Obstructions occupy less than } 15 \text { percent of the cross-sectional } \\
\text { area, and the spacing between obstructions is such that the } \\
\text { sphere of influence around one obstruction does not extend to } \\
\text { the sphere of influence around another obstruction. Smaller } \\
\text { adjustments are used for curved smooth-surfaced objects than } \\
\text { are used for sharp-edged angular objects. }\end{array}$ \\
\hline & Appreciable & $0.020-0.030$ & $\begin{array}{l}\text { Obstructions occupy from } 15 \text { to } 50 \text { percent of the cross-sectional } \\
\text { area, or the space between obstructions is small enough to } \\
\text { cause the effects of several obstructions to be additive, thereby } \\
\text { blocking an equivalent part of a cross section. }\end{array}$ \\
\hline & Severe & $0.040-0.060$ & $\begin{array}{l}\text { Obstructions occupy more than } 50 \text { percent of the cross-sectional } \\
\text { area, or the space between obstructions is small enough to } \\
\text { cause turbulence across most of the cross section. }\end{array}$ \\
\hline
\end{tabular}

${ }^{1}$ The original source of data presented in this table is Cowan (1956). Modifications from Chow (1959), Aldridge and Garrett (1973), and Jarrett (1985) are included.

${ }^{2}$ Adjustments are based primarily on data from channels less than $60 \mathrm{ft}$ wide and are probably applicable for channels as much as $10 \mathrm{C}$ ft wide, unless otherwise specified. Larger adjustments generally are necessary for narrower channels. 
Table A1-4.--Adjustment factors for the calculation of channel $n$ values--(continued) ${ }^{1}$

\begin{tabular}{|c|c|c|c|}
\hline \multicolumn{2}{|c|}{ Channel conditions } & \multirow{2}{*}{$\begin{array}{c}\begin{array}{c}\mathrm{n} \text {-value } \\
\text { adjustment }^{2}\end{array} \\
0.000\end{array}$} & $\begin{array}{l}\text { Example } \\
\text { (Italicized examples of vegetation are based } \\
\text { on results of data presented in this report.) }\end{array}$ \\
\hline \multirow[t]{5}{*}{$\begin{array}{l}\text { Channel vege- } \\
\text { tation, }{ }^{3} \mathrm{n}_{4} \text {. }\end{array}$} & Negligible & & $\begin{array}{l}\text { Any type or density of vegetation growing on the banks of channels } \\
\text { more than about } 100 \mathrm{ft} \text { wide with less than } 25 \text { percent of the wetted } \\
\text { perimeter vegetated and no significant vegetation along channel } \\
\text { bottoms. Mowed grass or vetch on banks of channels over } 50 \mathrm{ft} \\
\text { wide. (Could be applicable to narrower channels.) }\end{array}$ \\
\hline & Small & $0.002-0.010$ & $\begin{array}{l}\text { Dense growths of flexible turf grass, such as Bermuda, or weeds } \\
\text { growing where the average depth of flow is at least two times the } \\
\text { height of the vegetation; supple tree seedlings such as willow, } \\
\text { cottonwood, arrowweed, or saltcedar growing where the average } \\
\text { depth of flow is at least three times the height of the vegetation. } \\
\text { Dense woody brush, annual soft-stemmed plants, and possibly a few } \\
\text { mature trees that cover } 25 \text { to } 50 \text { percent of the wetted perimeter } \\
\text { in any season on the banks of channels from } 100 \text { to about } 250 \mathrm{ft} \\
\text { wide and during the dormant season on the banks of channels } \\
\text { from } 30 \text { to about } 100 \text { ft wide. }\end{array}$ \\
\hline & Medium & $0.010-0.025$ & $\begin{array}{l}\text { Turf grass growing where the average depth of flow is from one or } \\
\text { two times the height of the vegetation; moderately dense stemmy } \\
\text { grass, weeds, or tree seedlings growing where the average depth } \\
\text { of flow is from two to three times the height of the vegetation; } \\
\text { brushy, moderately dense vegetation, similar to } 1 \text { - to } 2 \text {-year-old } \\
\text { willow trees in the dormant season, or tall grasses and soft- } \\
\text { stemmed plants in the growing season, growing along the banks } \\
\text { and no significant vegetation along the channel bottoms where } \\
\text { the hydraulic radius exceeds } 2 \mathrm{ft} \text {. } \\
\text { Dense woody brush, annual soft-stemmed plants, and possibly a few } \\
\text { mature trees that cover } 25 \text { to } 50 \text { percent of the wetted perimeter } \\
\text { on the banks of channels from } 30 \text { to about } 100 \text { ft wide during the } \\
\text { growing season. }\end{array}$ \\
\hline & Large & $0.025-0.050$ & $\begin{array}{l}\text { Turf grass growing where the average depth of flow is about equal to } \\
\text { the height of vegetation; } 8 \text { - to } 10 \text {-year-old willow or cottonwood } \\
\text { trees intergrown with some weeds and brush (none of the vegeta- } \\
\text { tion in foliage) where the hydraulic radius exceeds } 2 \mathrm{ft} \text {; bushy } \\
\text { willows about } 1 \text { year old intergrown with some weeds along side } \\
\text { slopes (all vegetation in full foliage) and no significant vegetation } \\
\text { long channel bottoms where the hydraulic radius is greater than } \\
2 \mathrm{ft} \text {. }\end{array}$ \\
\hline & Very large & $0.050-0.100$ & $\begin{array}{l}\text { Turf grass growing where the average depth of flow is less than half } \\
\text { the height of the vegetation; bushy willow trees about } 1 \text { year old } \\
\text { intergrown with weeds along side slopes (all vegetation in full } \\
\text { foliage) or dense cattails growing along channel bottom; trees } \\
\text { intergrown with weeds and brush (all vegetation in full foliage). }\end{array}$ \\
\hline \multirow{3}{*}{$\begin{array}{l}\text { Degree of } \\
\text { meandering } \\
\text { m,5 }\end{array}$} & Minor & 1.00 & Ratio of the channel meander length $\left(\mathrm{L}_{\mathrm{m}}\right)$ to valley or straight- \\
\hline & Apprecia & 1.15 & $\mathrm{~L}_{\mathrm{m}} / \mathrm{L}_{\mathrm{s}}$ is 1.2 to 1.5 \\
\hline & Severe & 1.30 & $\mathrm{~L}_{\mathrm{m}} / \mathrm{L}_{\mathrm{s}}$ is greater than 1.5 \\
\hline
\end{tabular}

\footnotetext{
${ }^{3}$ Note the distinction in the examples between vegetation distributed uniformly across a channel, which is assumed, and bank vegetation alone.

${ }^{4}$ Adjustment values apply to flow confined in the channel and do not apply where downvalley flow crosses meanders.

${ }^{5}$ Adjustments for cross-section irregularities, channel variations, effect of obstructions, and channel vegetation are added to the initial $n$ value (tables A1-1, A1-2 or A1-3 or the estimation equations). This sum is multiplied by the adjustment factor for degree of meandering.
} 


\section{APPENDIX 2}

\section{PHOTOGRAPHS, STATION DESCRIPTIONS, AND HYDRAULIC DATA FOR EACH SITE, WITH PLAN VIEW, CHANNEL CROSS SECTIONS, AND GRAPH OF RELA- TION BETWEEN HYDRAULIC RADIUS AND MANNING'S ROUGHNESS COEFFICIENT}

This section presents photographs showing upstream and downstream views and includes physical descriptions of the 21 study sites, as well as the hydraulic data for each discharge and water-surface profile for which a roughness coefficient is computed. The photographs are intended to show channel alignment, streambank vegetation, channel size in relation to flow-resisting features, and, where possible, bed material. For reference scale in the photographs, a hydrographer (5-ft, 7-in. tall) is holding either a telescoping stadia rod (the length of which is stated in the photograph caption) or a 2.6-ft-by-1.6-ft crosssection-identification card. The vegetation indices for bankfull flows are listed as a pair of numbers that represent average vegetation conditions for both streambanks during the nongrowing- and growingseasons, respectively. Velocity-head coefficients $(\propto)$, where given, are computed from discharge measurements made at stages similar to those recorded during this study. All data in the tables except discharge, water-surface slope, energy gradient, and Manning's roughness coefficient (n) are averages of values computed for each cross section within a reach. The percentage of wetted perimeter that is vegetated is computed from the average values of the total wetted perimeter and the wetted perimeter that is vegetated at each cross section in the reach. Roughness coefficients for three sites-Esopus Creek at Coldbrook, Beaver Kill at Cooks Falls, and East Branch Ausable River at Au Sable Forks - have been computed from data from earlier floods. These data, which are presented in Barnes (1967), are included herein for comparison with the recent computations. Graphs show the relation between Manning's roughness coefficient and hydraulic radius at each site. Plan-view diagrams of the study reaches show cross-section locations and orientation of photographs. Cross-section plots illustrate the variation of channel size and shape within the study reach. The horizontal lines on the crosssection plots depict the water-surface elevations of the maximum and minimum recorded discharges listed in the data table for each site. Data and photographs are included for the following sites:

1. Tremper Kill near Andes

2. Scajaquada Creek at Buffalo

3. Moordener Kill at Castleton-on-Hudson

4. Canisteo River at Arkport

5. Mill Brook near Dunraven

6. East Branch Ausable River at Au Sable Forks

7. Beaver Kill at Cooks Falls

8. Onondaga Creek at Dorwin Avenue, Syracuse

9. Tioughnioga River at Itaska

10. Kayaderosseras Creek near West Milton

11. Indian River near Indian Lake

12. Sacandaga River at Stewarts Bridge, near Hadley

13. Esopus Creek at Coldbrook

14. East Branch Delaware River at Margaretville

15. Ouleout Creek at East Sidney

16. Susquehanna River at Unadilla

17. Unadilla River at Rockdale

18. Tioughnioga River at Cortland

19. Chenango River near Chenango Forks

20. Genesee River near Mount Morris

21. Trout River at Trout River 


\section{SITE 1. TREMPER KILL NEAR ANDES, N.Y.}

Table A2-1. Station description and hydraulic data

Location.--Latitude $42^{\circ} 07^{\prime} 12^{\prime \prime}$, longitude $74^{\circ} 49^{\prime} 08^{\prime \prime}$, Delaware County, on right bank $500 \mathrm{ft}$ upstream from bridge on County Highway 1, about 1,700 ft upstream from Pepacton Reservoir, and $5 \mathrm{mi}$ south of Andes. A 3-section, 166-ft-long reach; section 1 is about $220 \mathrm{ft}$ upstream from bridge on County Highway 1.

USGS station-identification number.--01415000.

Drainage area.--32.2 $\mathrm{mi}^{2}$.

Bed material.--Rounded cobbles and boulders. Intermediate diameter $\mathrm{d}_{50}=0.70 \mathrm{ft}$ and $\mathrm{d}_{84}=1.45 \mathrm{ft}$.

Minimum diameter $\mathrm{d}_{50}=0.16 \mathrm{ft}$.

Bank description.--Left bank is steep and eroded; has boulders and exposed tree roots. Right bank is gradually sloped and is vegetated with a few large trees, some bamboo, but mostly tall grass and soft-stemmed plants. Vegetation indices: 1, 2.

Remarks.--The $\mathrm{n}$ values computed for this site are affected by streambank vegetation.

\section{Hydraulic Data}

$\left[\mathrm{ft}=\mathrm{feet} ; \mathrm{ft}^{2}=\right.$ square feet; $\mathrm{ft} / \mathrm{s}=$ feet per second; $\mathrm{ft}^{3} / \mathrm{s}=$ cubic feet per second. $]$

\begin{tabular}{|c|c|c|c|c|c|c|c|c|c|}
\hline \multirow[b]{2}{*}{$\begin{array}{c}\text { Discharge } \\
\left(\mathrm{ft}^{3} / \mathrm{s}\right)\end{array}$} & \multicolumn{5}{|c|}{ Average values for reach } & \multirow[b]{2}{*}{$\begin{array}{c}\text { Water- } \\
\text { surface } \\
\text { slope }\end{array}$} & \multirow[b]{2}{*}{$\begin{array}{c}\text { Energy } \\
\text { gradient }\end{array}$} & \multirow[b]{2}{*}{$\begin{array}{c}\text { Percent } \\
\text { wetted } \\
\text { perimeter } \\
\text { vegetated }\end{array}$} & \multirow[b]{2}{*}{$\begin{array}{c}\text { Manning's } \\
n\end{array}$} \\
\hline & $\begin{array}{l}\text { Area } \\
\left(\mathrm{ft}^{2}\right)\end{array}$ & $\begin{array}{l}\text { Width } \\
(\mathrm{ft})\end{array}$ & $\begin{array}{l}\text { Hydraulic } \\
\text { radius } \\
\text { (ft) }\end{array}$ & $\begin{array}{c}\text { Velocity } \\
(\mathrm{ft} / \mathrm{s})\end{array}$ & $\begin{array}{l}\text { Froude } \\
\text { number }\end{array}$ & & & & \\
\hline \multicolumn{10}{|c|}{ Data collected during the non-growing season } \\
\hline 85 & 35.9 & 37.1 & 0.91 & 2.38 & 0.43 & 0.01006 & 0.01001 & 24.2 & 0.059 \\
\hline 241 & 65.9 & 41.5 & 1.49 & 3.66 & .51 & .01084 & .01068 & 32.7 & .054 \\
\hline$\ddagger 248$ & 70.6 & 42.0 & 1.57 & 3.52 & .48 & .00934 & .00941 & 33.9 & .055 \\
\hline$\$ 271$ & 71.3 & 42.1 & 1.58 & 3.81 & .51 & .00988 & .00986 & 33.9 & .053 \\
\hline$\ddagger 315$ & 80.1 & 42.9 & 1.74 & 3.95 & .51 & .00964 & .00962 & 35.5 & .054 \\
\hline$\ddagger 355$ & 86.9 & 43.5 & 1.85 & 4.11 & .51 & .00994 & .00985 & 36.4 & .055 \\
\hline 597 & 120 & 47.6 & 2.34 & 4.98 & .55 & .01060 & .01061 & 42.1 & .054 \\
\hline 1040 & 164 & 53.2 & 2.84 & 6.36 & .64 & .01229 & .01205 & 48.2 & .052 \\
\hline \multicolumn{10}{|c|}{ Data collected during the growing season } \\
\hline 175 & 60.9 & 41.0 & 1.40 & 2.88 & .42 & .01066 & .01057 & 31.7 & .066 \\
\hline$\ddagger 414$ & 105 & 45.6 & 2.13 & 3.96 & .46 & .01054 & .01043 & 39.5 & .064 \\
\hline$\ddagger 419$ & 106 & 45.6 & 2.14 & 3.98 & .46 & .01042 & .01026 & 39.6 & .065 \\
\hline$\$ 494$ & 111 & 46.3 & 2.21 & 4.49 & .51 & .01060 & .01045 & 40.5 & .058 \\
\hline$\ddagger 691$ & 141 & 50.3 & 2.59 & 4.92 & .52 & .01000 & .01016 & 45.2 & .058 \\
\hline 832 & 156 & 52.2 & 2.76 & 5.35 & .54 & .01084 & .01097 & 47.2 & .057 \\
\hline
\end{tabular}

$\ddagger$ The $\mathrm{n}$ value computed for this discharge and water-surface profile is affected by 11 to 18 percent flow-area expansion in the reach. The $\mathrm{n}$ values computed for each subreach differ by 0.010 to 0.020 . 


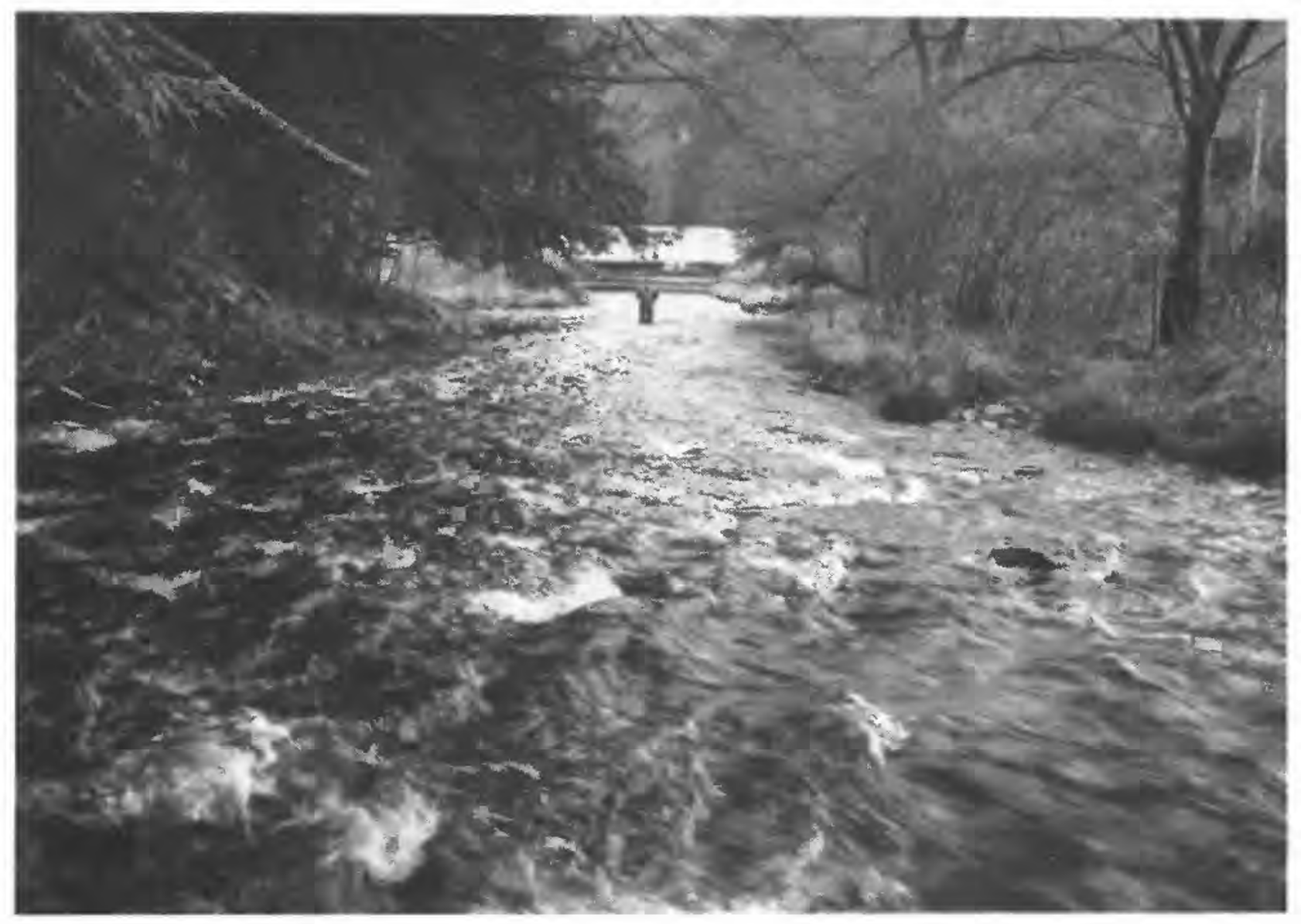

View from above cross section 1, facing downstream.

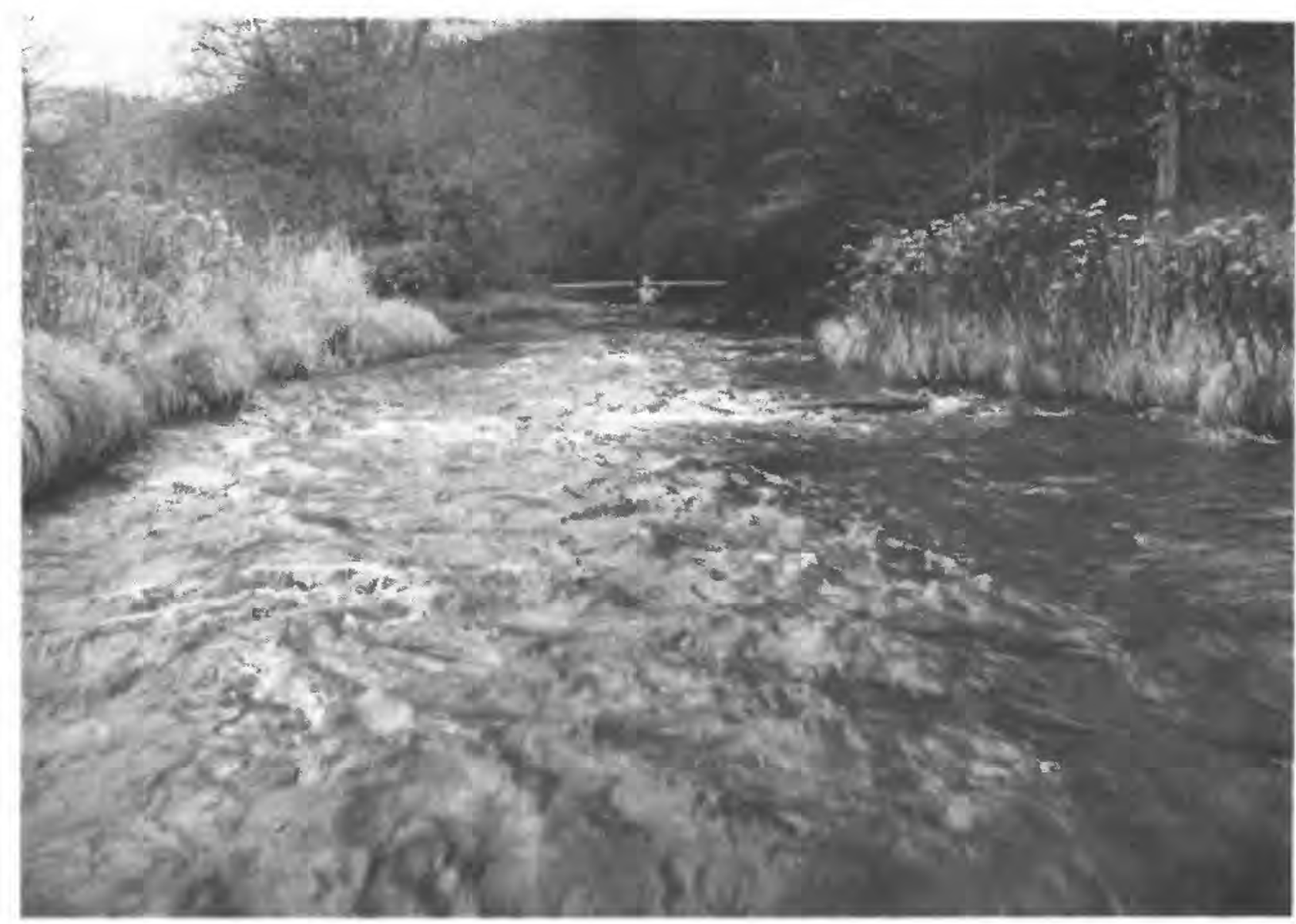

View from below cross section 3, facing upstream. Hydrographer is at cross section 2.

Figure A2-1. Tremper Kill near Andes, N.Y. A. Photographs of reach during late fall. Hydrographer is holding a 15foot rod at approximate water-surface elevation of maximum recorded discharge. 


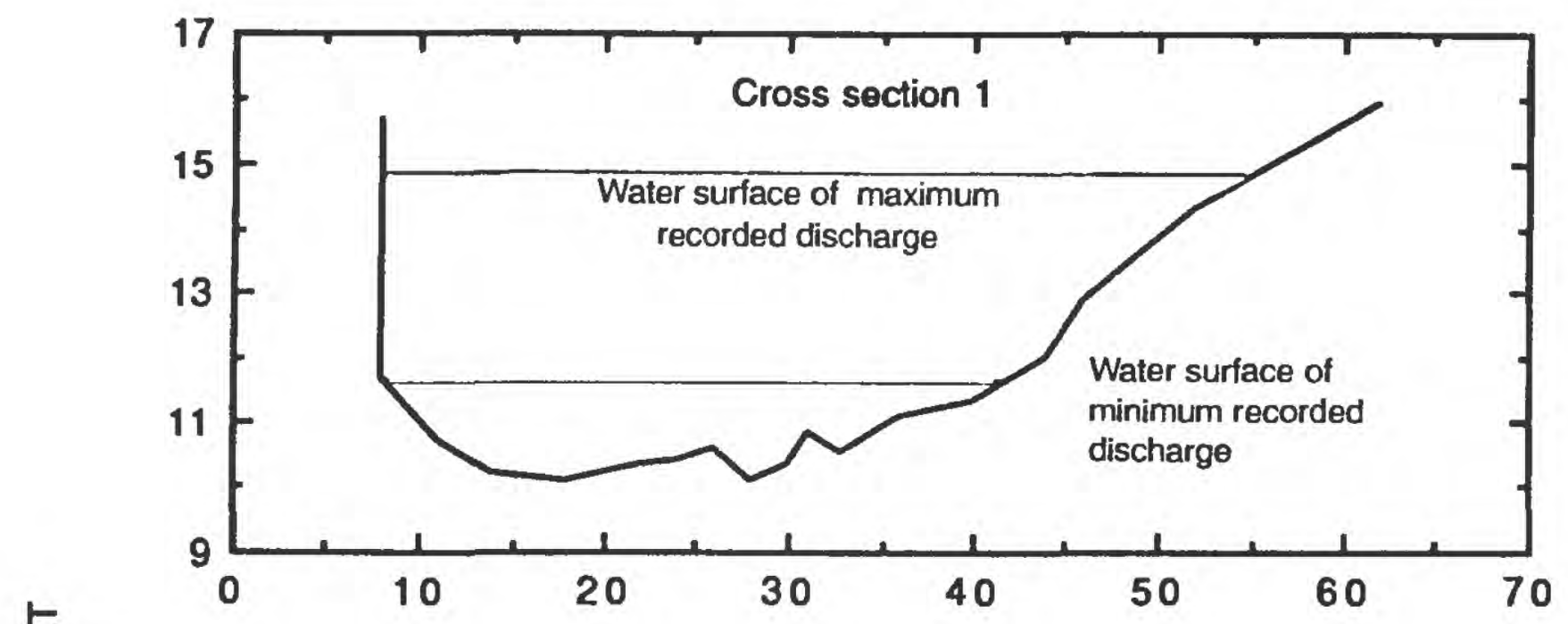

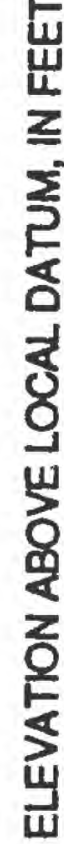
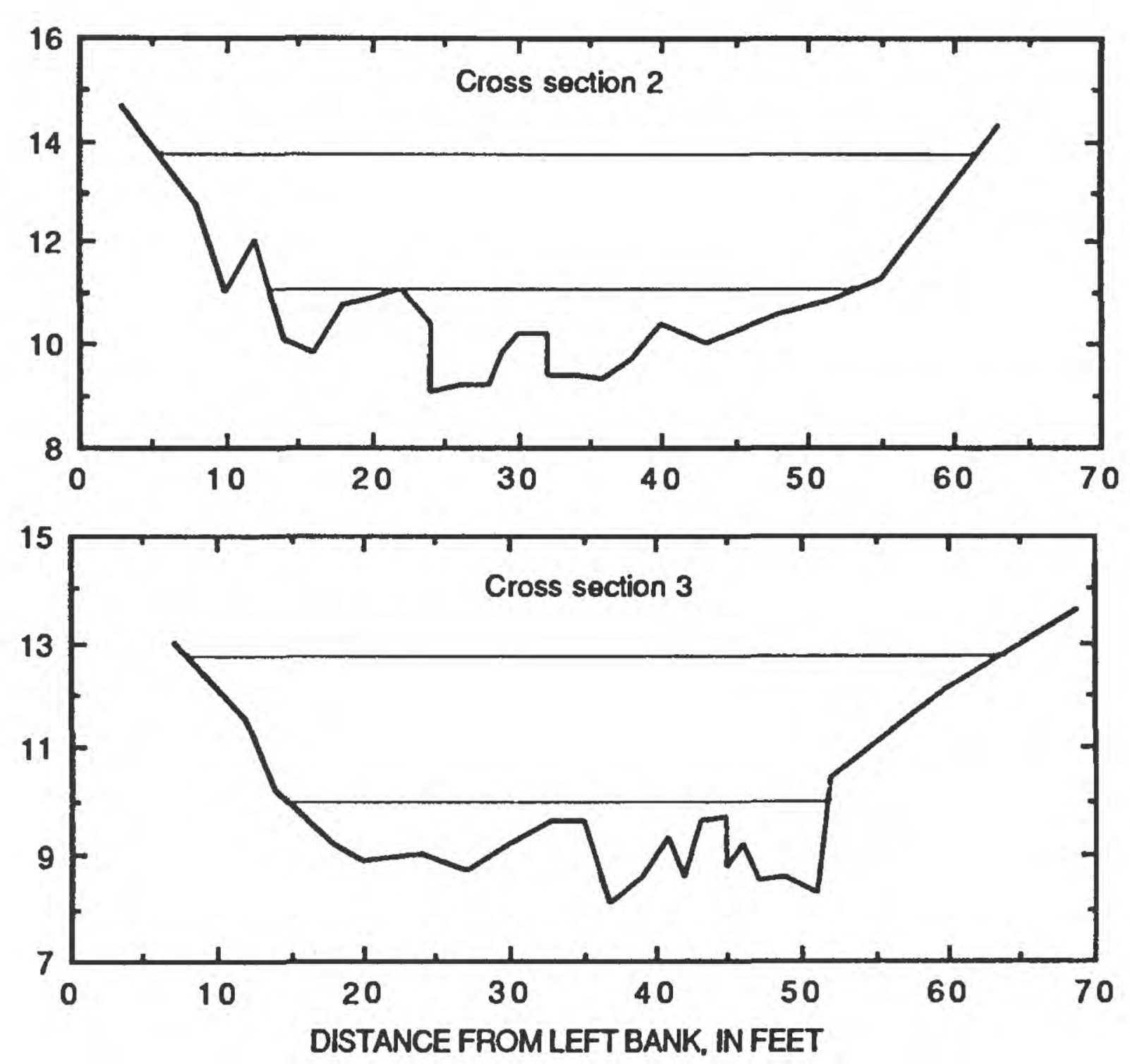

Figure A2-1. Tremper Kill near Andes, N.Y. (continued), B. Cross sections 1, 2, and 3. (Locations are shown in plan view on p. 47.) 
PLAN VIEW (not to scale)

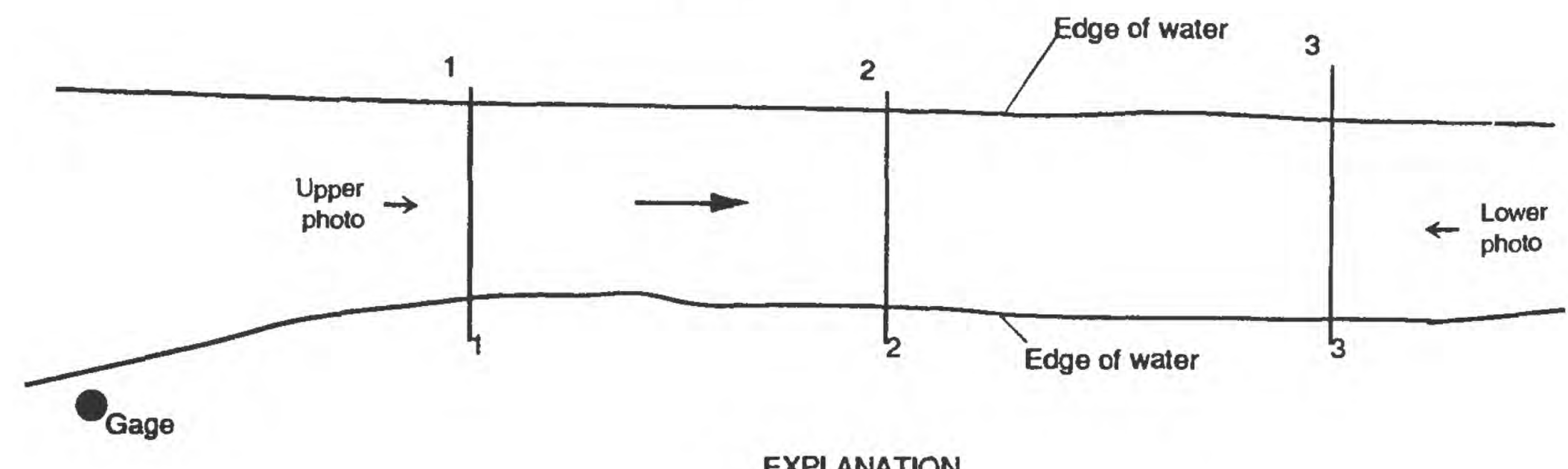

EXPLANATION
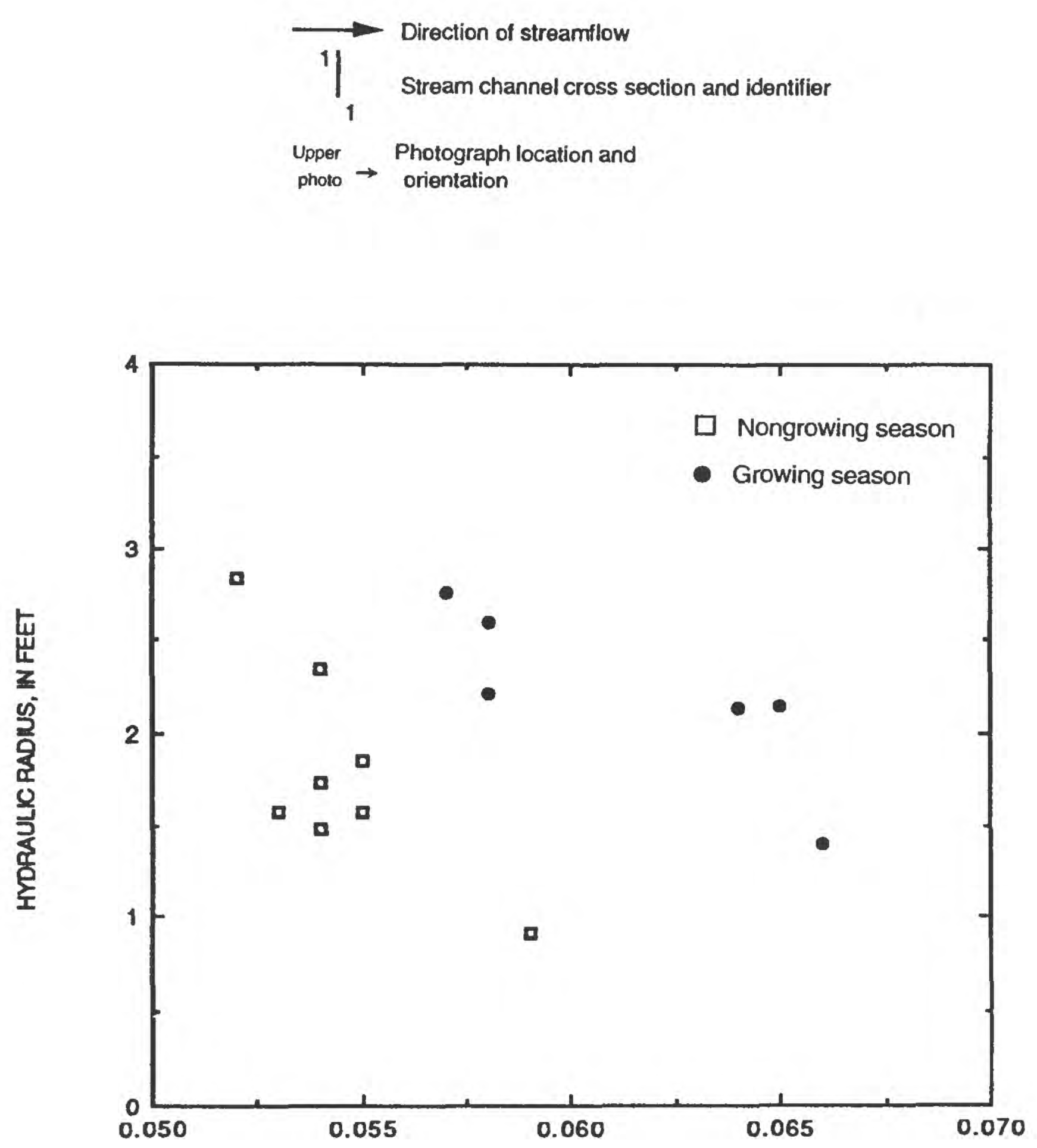

MANNING'S ROUGHNESS COEFFICIENT, $n$

Figure A2-1. Tremper Kill near Andes, N.Y. (continued). C. Plan view and relation between hydraulic radius and Manning's roughness coefficient during growing and nongrowing seasons. 


\section{SITE 2. SCAJAQUADA CREEK AT BUFFALO, N.Y.}

Table A2-2. Station description and hydraulic data

Location.--Latitude $42^{\circ} 54^{\prime} 41^{\prime \prime}$, longitude $78^{\circ} 47^{\prime} 45^{\prime \prime}$, Erie County, on right bank $58 \mathrm{ft}$ upstream from point where stream goes underground in concrete-lined tunnel, $86 \mathrm{ft}$ upstream from Pine Ridge Road, 0.2 mi east of boundary line of City of Buffalo, and 6.2 mi upstream from mouth. A 3-section, 860 - $\mathrm{ft}$-long reach; section 1 is about $1,100 \mathrm{ft}$ upstream from gage and just downstream from footbridge.

USGS station-identification number.--04216200.

Drainage area.--15.4 $\mathrm{mi}^{2}$.

Bed material.--Gravel. Intermediate diameter $\mathrm{d}_{50}=0.06$ and $\mathrm{d}_{84}=0.17 \mathrm{ft}$. Minimum diameter $\mathrm{d}_{50}=0.04 \mathrm{ft}$.

Bank description.--This reach is a maintained grass- and vetch-lined channel with a dense growth of willow saplings and grass at the low-water's edge. Vegetation indices: lower bank: 3,4; bankfull: 0,0 .

Remarks.--The $n$ values computed at this site are affected by streambank vegetation and by 24 to 31 percent flow-area expansion in the reach. The velocity-head coefficients computed from discharge measurements made at this site range from 1.14 to 1.24 for discharges between 330 and $760 \mathrm{ft}^{3} / \mathrm{s}$.

\section{Hydraulic Data}

[ft = feet; $\mathrm{ft}^{2}=$ square feet; $\mathrm{ft} / \mathrm{s}=$ feet per second; $\mathrm{ft}^{3} / \mathrm{s}=$ cubic feet per second.]

\begin{tabular}{|c|c|c|c|c|c|c|c|c|c|}
\hline \multirow[b]{2}{*}{$\begin{array}{c}\text { Discharge } \\
\left(\mathrm{ft}^{3} / \mathrm{s}\right)\end{array}$} & \multicolumn{5}{|c|}{ Average values for reach } & \multirow[b]{2}{*}{$\begin{array}{l}\text { Water- } \\
\text { surface } \\
\text { slope }\end{array}$} & \multirow[b]{2}{*}{$\begin{array}{l}\text { Energy } \\
\text { gradient }\end{array}$} & \multirow[b]{2}{*}{$\begin{array}{c}\text { Percent } \\
\text { wetted } \\
\text { perimeter } \\
\text { vegetated }\end{array}$} & \multirow[b]{2}{*}{$\begin{array}{c}\text { Manning's } \\
n\end{array}$} \\
\hline & $\begin{array}{c}\text { Area } \\
\left(\mathrm{ft}^{2}\right)\end{array}$ & $\begin{array}{l}\text { Width } \\
\text { (ft) }\end{array}$ & $\begin{array}{l}\text { Hydraulic } \\
\text { radius } \\
\text { (ft) }\end{array}$ & $\begin{array}{c}\text { Velocity } \\
\text { (ft/s) }\end{array}$ & $\begin{array}{l}\text { Froude } \\
\text { number }\end{array}$ & & & & \\
\hline
\end{tabular}

\begin{tabular}{|c|c|c|c|c|c|c|c|c|c|}
\hline \multicolumn{10}{|c|}{ Data collected during the non-growing season } \\
\hline 453 & 169 & 54.2 & 3.02 & 2.77 & 0.28 & 0.00037 & 0.00043 & 27.9 & 0.024 \\
\hline 492 & 178 & 55.2 & 3.13 & 2.83 & .28 & .00048 & .00053 & 29.3 & .026 \\
\hline 542 & 189 & 56.3 & 3.25 & 2.94 & .29 & .00044 & .00050 & 30.7 & .025 \\
\hline 562 & 199 & 57.4 & 3.36 & 2.89 & .28 & .00043 & .00048 & 32.1 & .026 \\
\hline 734 & 249 & 62.5 & 3.87 & 3.00 & .27 & .00050 & .00055 & 37.7 & .029 \\
\hline 759 & 257 & 63.2 & 3.94 & 3.00 & .26 & .00050 & .00055 & 38.5 & .029 \\
\hline \multicolumn{10}{|c|}{ Data collected during the growing season } \\
\hline 329 & 136 & 50.5 & 2.62 & 2.49 & .27 & .00051 & .00055 & 22.5 & .027 \\
\hline 332 & 134 & 50.4 & 2.60 & 2.54 & .28 & .00053 & .00058 & 22.2 & .027 \\
\hline 370 & 146 & 51.8 & 2.75 & 2.59 & .27 & .00059 & .00063 & 24.4 & .029 \\
\hline 430 & 165 & 53.6 & 2.98 & 2.66 & .27 & .00063 & .00066 & 27.4 & .031 \\
\hline 455 & 172 & 54.6 & 3.06 & 2.70 & .27 & .00069 & .00072 & 28.4 & .032 \\
\hline 476 & 181 & 55.6 & 3.16 & 2.68 & .26 & .00069 & .00072 & 29.7 & .033 \\
\hline 544 & 197 & 57.3 & 3.35 & 2.81 & .27 & .00056 & .00060 & 31.9 & .030 \\
\hline 578 & 207 & 58.2 & 3.45 & 2.85 & .27 & .00056 & .00060 & 33.0 & .030 \\
\hline
\end{tabular}




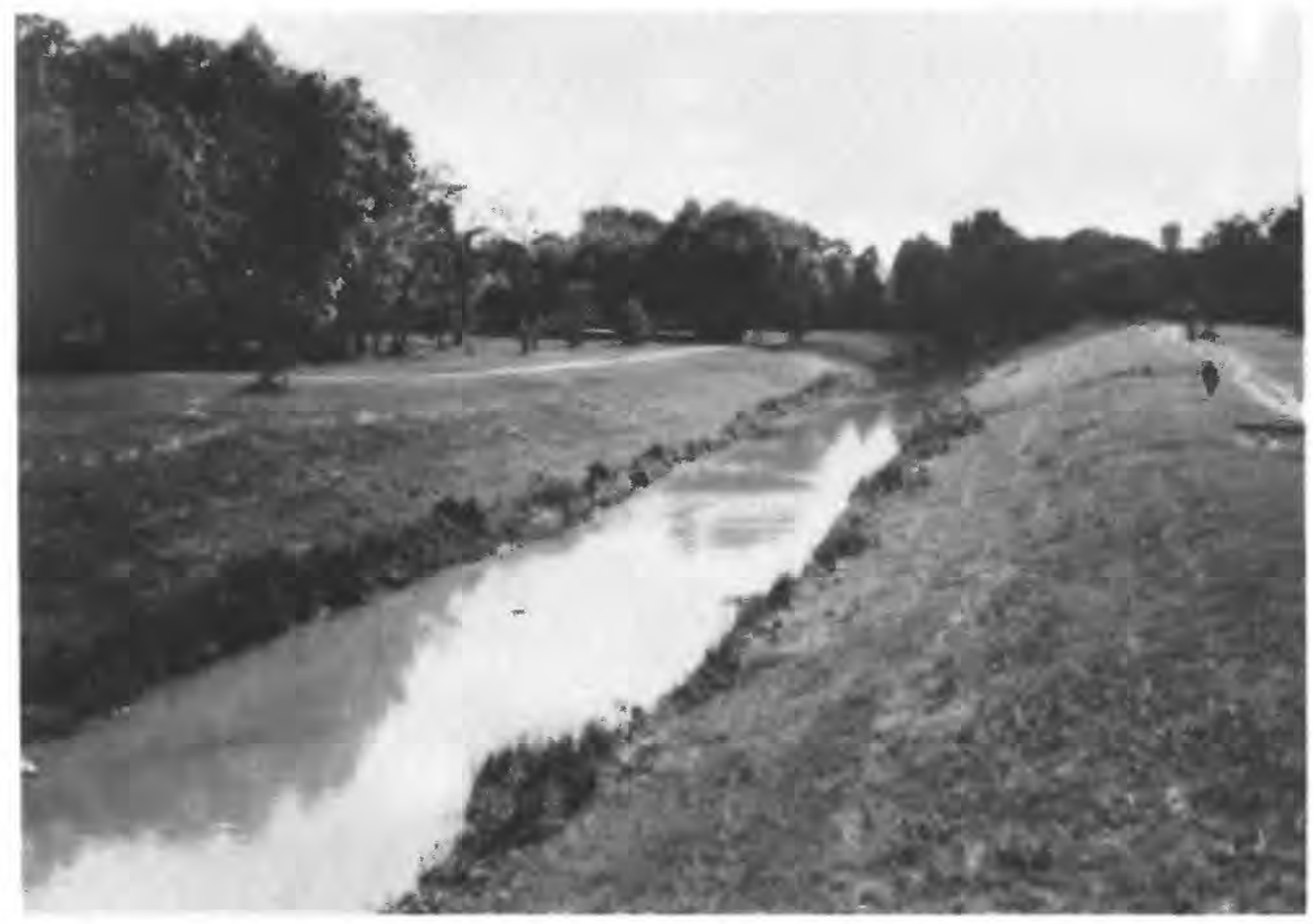

Vew from cross section 1, facing downstream across channel.

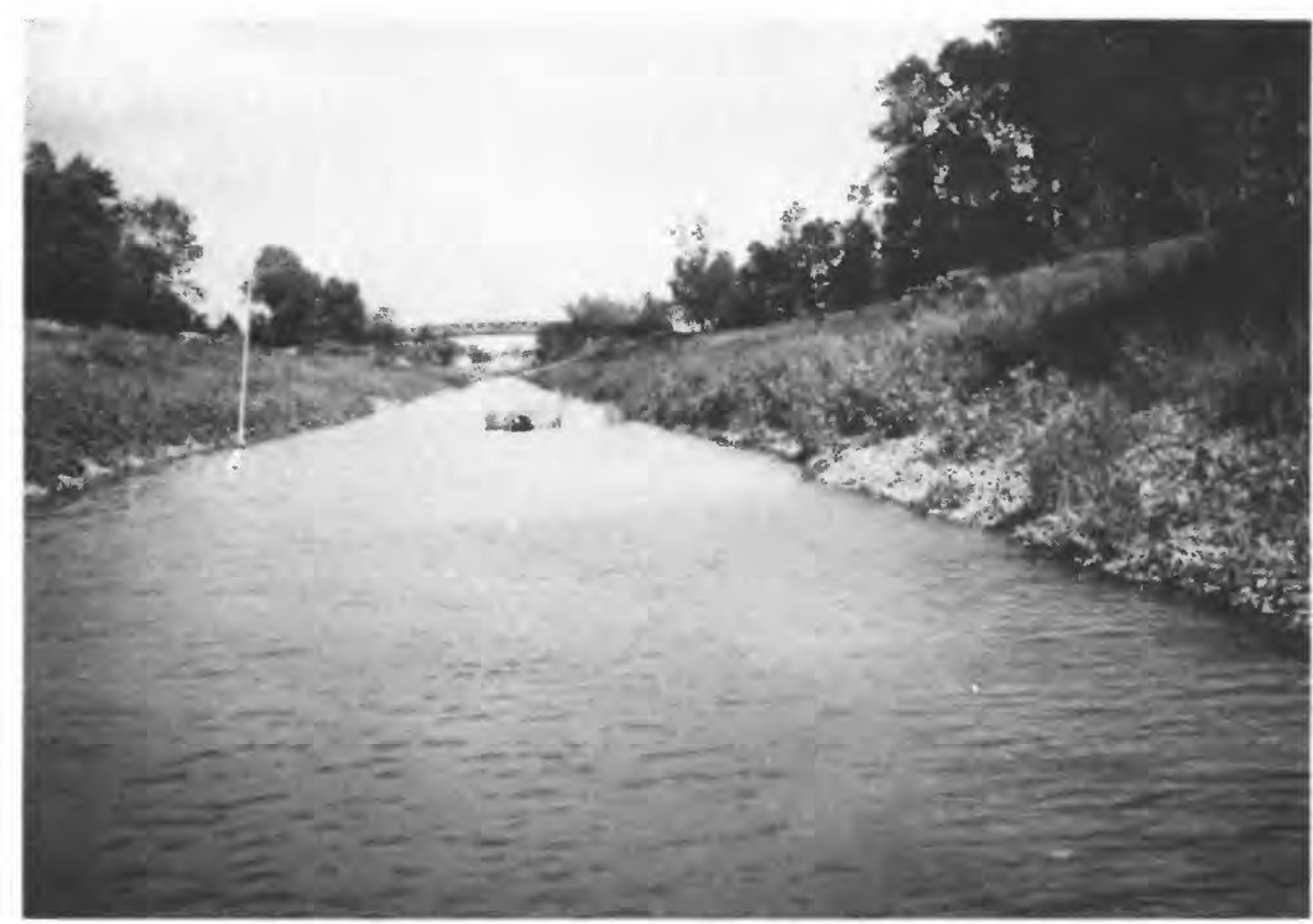

View from below cross section 2, facing upstream.

A stadia rod supported by a tripod is extended to $10 \mathrm{ft}$.

Figure A2-2. Scajaquada Creek at Buffalo, N.Y. A. Photographs during growing season. 


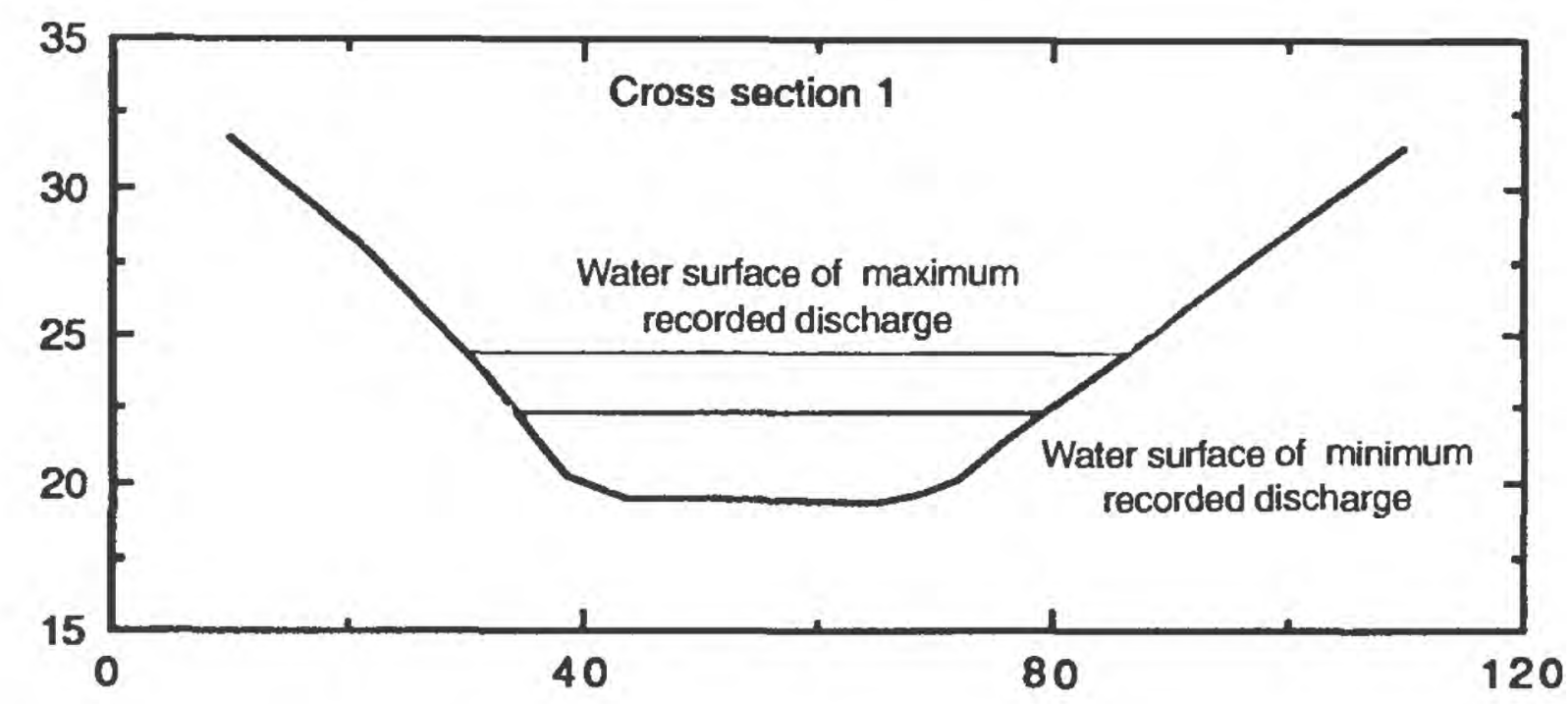

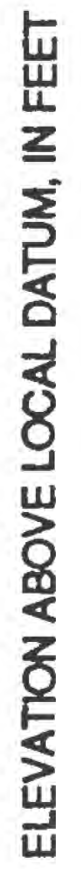
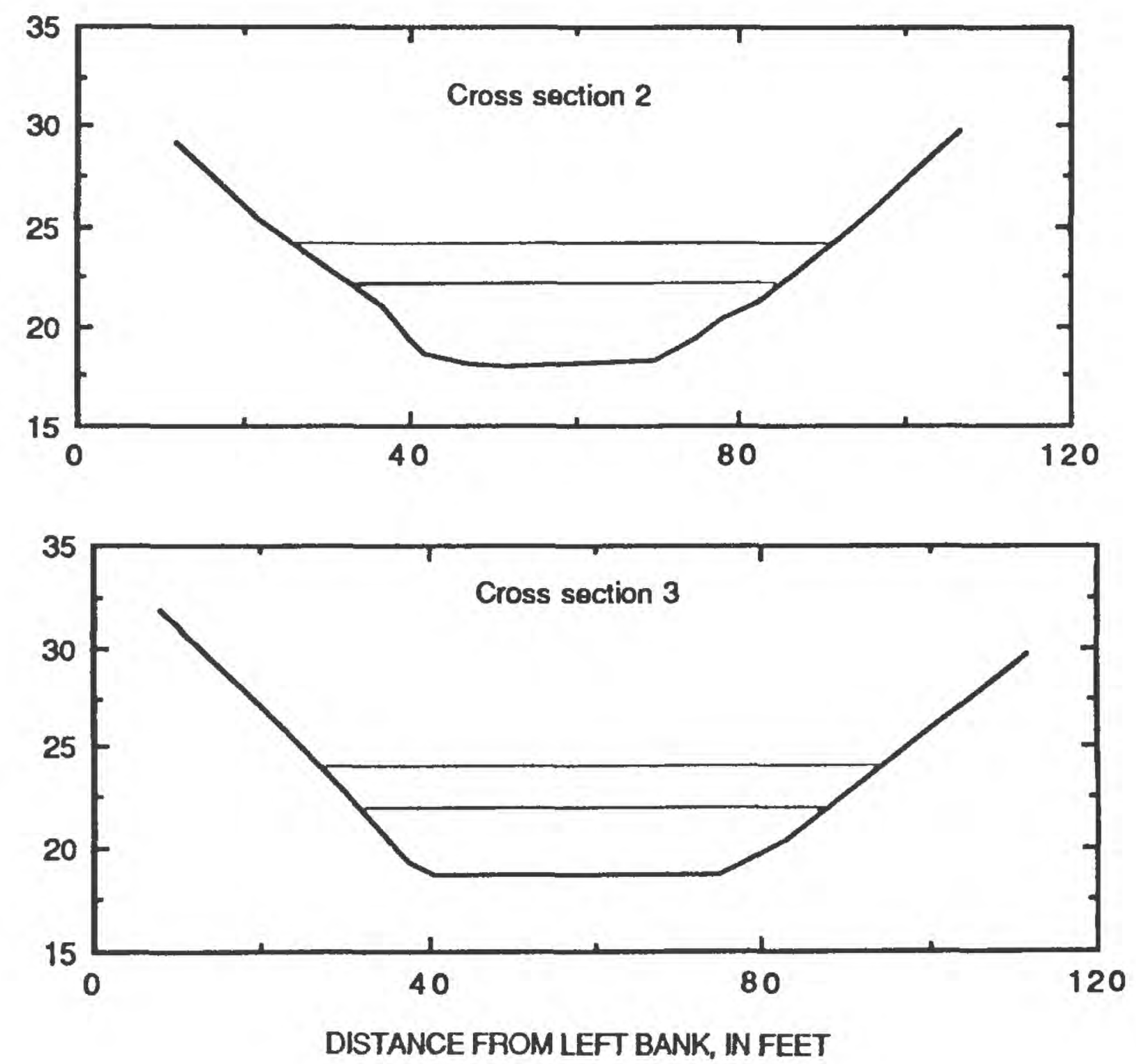

Figure A2-2. Scajaquada Creek at Buffalo, N.Y. (continued). B. Cross sections. (Locations are shown in plan view on p. 51.) 
PLAN VIEW (not to scale)

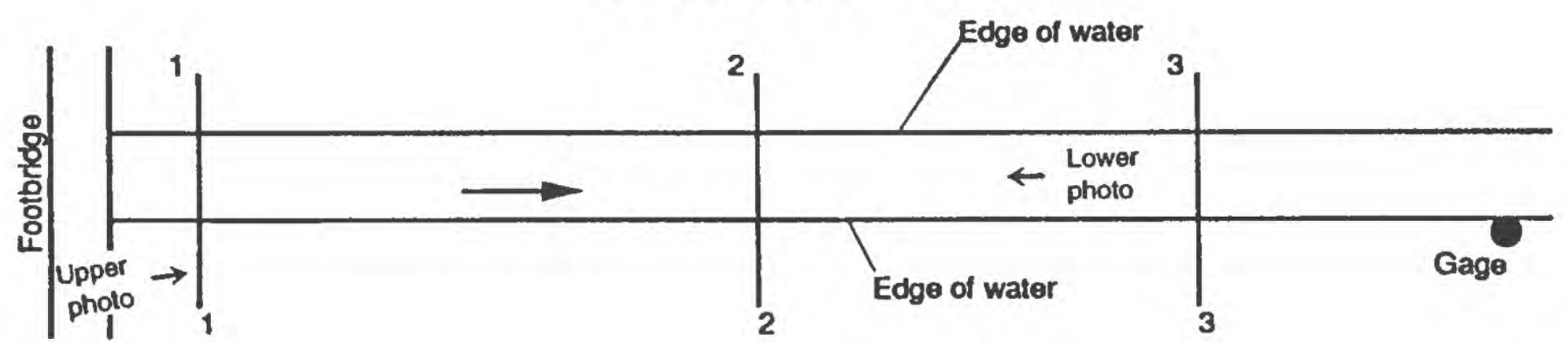

EXPLANATION
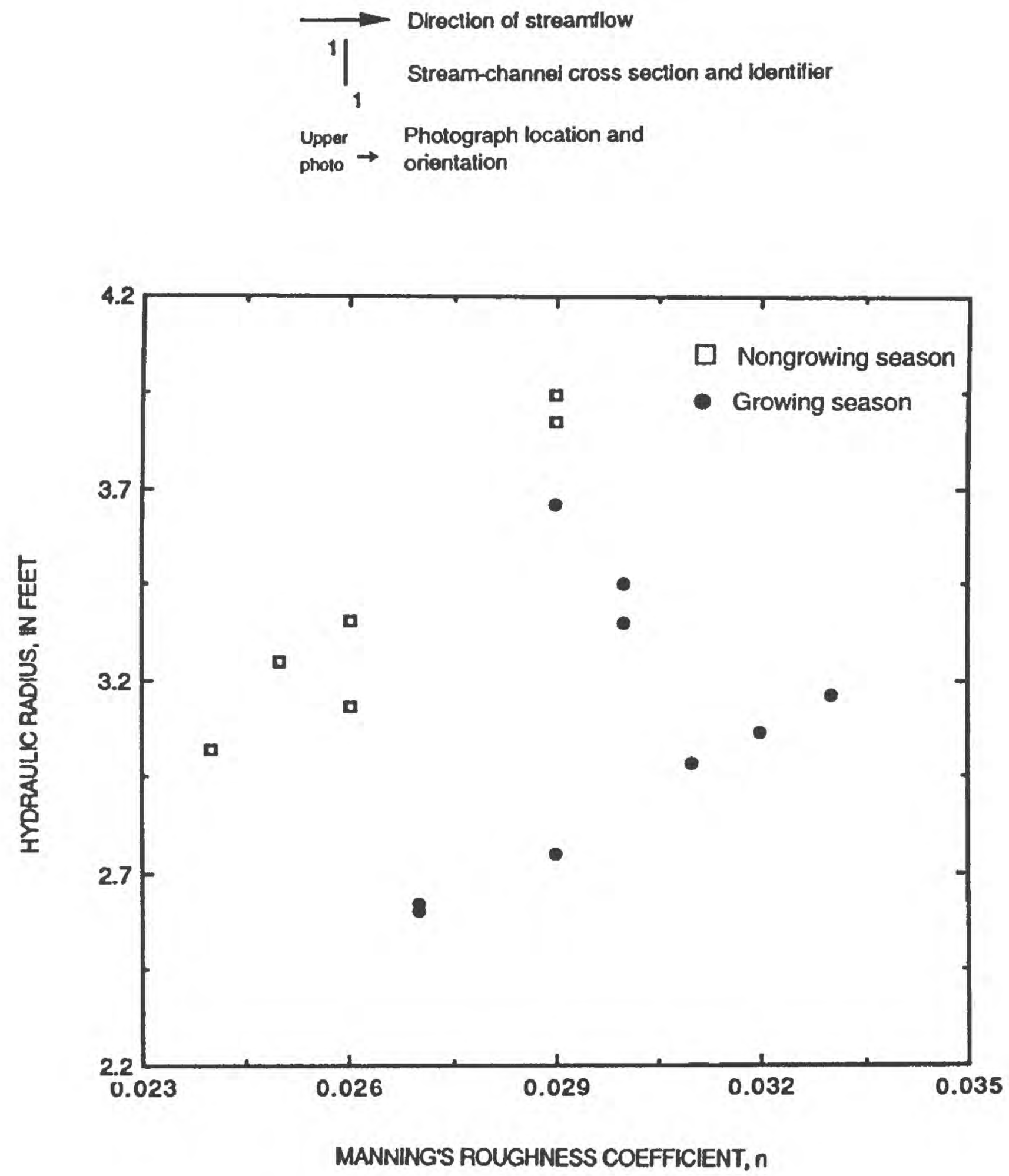

Figure A2-2. Scajaquada Creek at Buffalo, N.Y. (continued). C. Plan view and relation between hydraulic radius and Manning's roughness coefficient during growing and nongrowing seasons. 


\section{SITE 3. MOORDENER KILL AT CASTLETON-ON-HUDSON, N.Y}

\section{Table A2-3. Station description and hydraulic data}

Location.--Latitude $42^{\circ} 32^{\prime} 02^{\prime \prime}$, longitude $73^{\circ} 44^{\prime} 15^{\prime \prime}$, Rensselaer County, on left bank $800 \mathrm{ft}$ downstream from bridge on State Highway 150, 0.2 mi east of village of Castleton-on-Hudson, $0.5 \mathrm{mi}$ downstream from unnamed tributary, and $1.2 \mathrm{mi}$ upstream from mouth. A 2-section, 141-ft-long reach is 0.25 mi upstream from bridge on State Highway 150.

USGS station-identification number.--01359750.

Drainage area.--32.6 $\mathrm{mi}^{2}$.

Bed material.--Small gravel and sand over bedrock. Intermediate diameter $\mathrm{d}_{50}=0.05 \mathrm{ft}$ and $\mathrm{d}_{84}=0.14$ ft. Minimum diameter $\mathrm{d}_{50}=0.02 \mathrm{ft}$.

Bank description.--Both banks have a few trees, 2 to $3 \mathrm{ft}$ in diameter; sparsely spaced about $20 \mathrm{ft}$ apart. Dense woody brush and vines cover most of the banks. Summertime growth of leaves, grasses, and soft-stemmed plants essentially doubles the vegetation cover. Vegetation indices: 2, 4 .

Remarks.--The $\mathrm{n}$ values computed for this site are affected by streambank vegetation.

\section{Hydraulic Data}

$\left[\mathrm{ft}=\mathrm{feet} ; \mathrm{ft}^{2}=\right.$ square feet; $\mathrm{ft} / \mathrm{s}=$ feet per second; $\mathrm{ft}^{3} / \mathrm{s}=$ cubic feet per second. $]$

\begin{tabular}{|c|c|c|c|c|c|c|c|c|c|}
\hline \multirow[b]{2}{*}{$\begin{array}{c}\text { Discharge }+ \\
\left(\mathrm{ft}^{3} / \mathrm{s}\right)\end{array}$} & \multicolumn{5}{|c|}{ Average values for reach } & \multirow[b]{2}{*}{$\begin{array}{l}\text { Water- } \\
\text { surface } \\
\text { slope }\end{array}$} & \multirow[b]{2}{*}{$\begin{array}{c}\text { Energy } \\
\text { gradient }\end{array}$} & \multirow[b]{2}{*}{$\begin{array}{c}\text { Percent } \\
\text { wetted } \\
\text { perimeter } \\
\text { vegetated }\end{array}$} & \multirow[b]{2}{*}{$\underset{n}{\text { Manning's }}$} \\
\hline & $\begin{array}{l}\text { Area } \\
\left(\mathrm{ft}^{2}\right)\end{array}$ & $\begin{array}{l}\text { Width } \\
\text { (ft) }\end{array}$ & $\begin{array}{l}\text { Hydraulic } \\
\text { radius } \\
\text { (ft) }\end{array}$ & $\begin{array}{l}\text { Velocity } \\
(\mathrm{ft} / \mathrm{s})\end{array}$ & $\begin{array}{l}\text { Froude } \\
\text { number }\end{array}$ & & & & \\
\hline$* \neq 77$ & 46.1 & 37.0 & 1.26 & 1.70 & 0.27 & 0.00156 & 0.00164 & 6.7 & 0.041 \\
\hline$\ddagger 122$ & 56.4 & 38.1 & 1.48 & 2.18 & .32 & .00156 & .00164 & 9.6 & .036 \\
\hline$\$ 140$ & 60.6 & 38.6 & 1.57 & 2.32 & .33 & .00121 & .00130 & 10.9 & .031 \\
\hline a250 & 93.2 & 42.3 & 2.16 & 2.68 & .32 & .00142 & .00145 & 19.5 & .035 \\
\hline 333 & 104 & 43.5 & 2.33 & 3.20 & .36 & .00156 & .00158 & 21.9 & .032 \\
\hline$a \ddagger 374$ & 123 & 45.9 & 2.60 & 3.04 & .33 & .00170 & .00166 & 26.5 & .038 \\
\hline 409 & 127 & 46.6 & 2.63 & 3.23 & .34 & .00149 & .00147 & 27.4 & .034 \\
\hline
\end{tabular}

$\$$ The $n$ value computed for this discharge and water-surface profile is affected by 14 to 22 percent flow-area expansion in the reach. The total water-surface fall is less than $0.25 \mathrm{ft}$.

* The data used for this n-value calculation were collected during the growing season.

a The data used for this n-value calculation were collected during the post-growing season before snow accumulation and appear to reflect the effect of streambank vegetation in a manner similar to data collected during the growing season. 


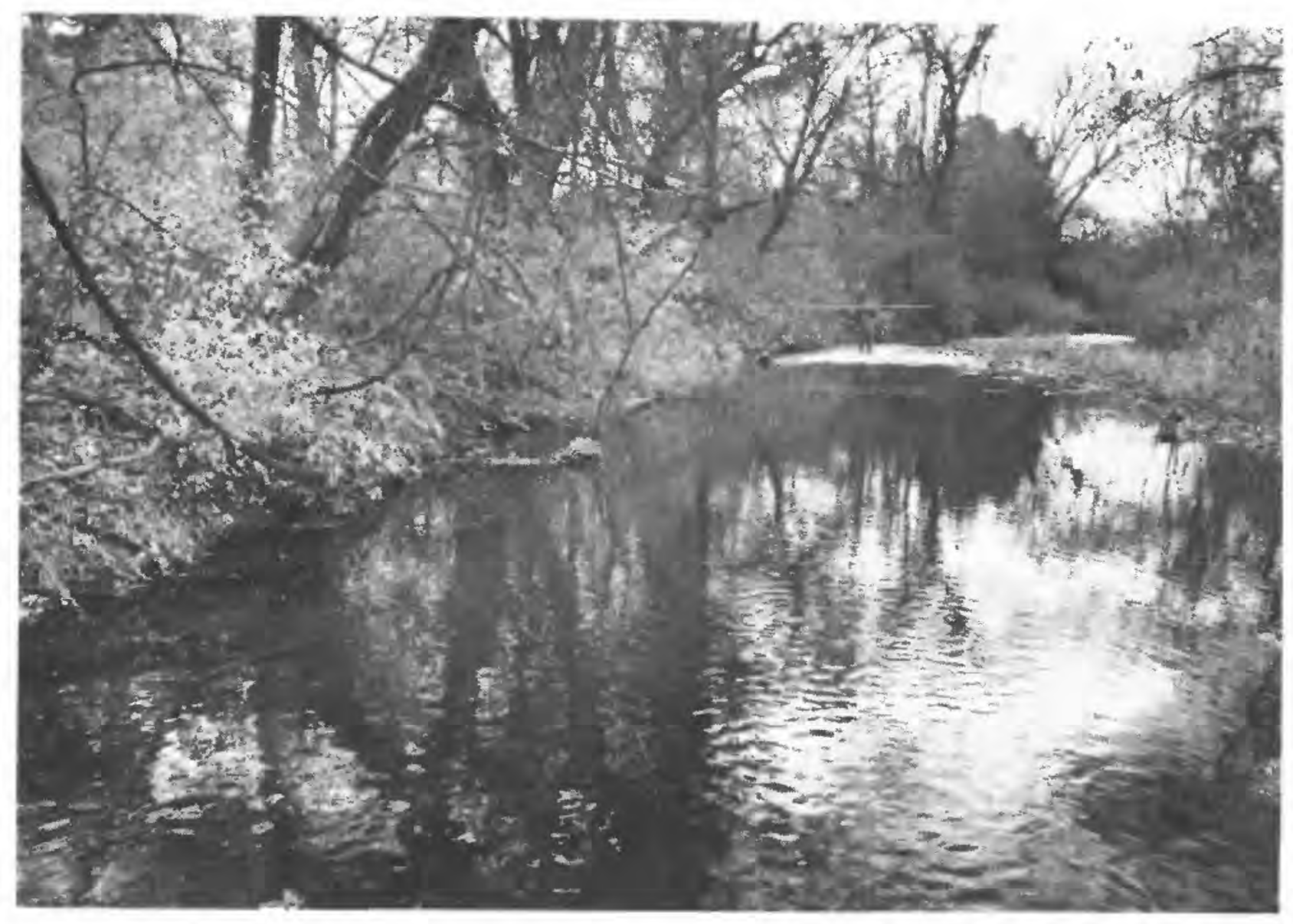

View from cross section 1, facing downstream along left bank. Hydrographer is near section 2.

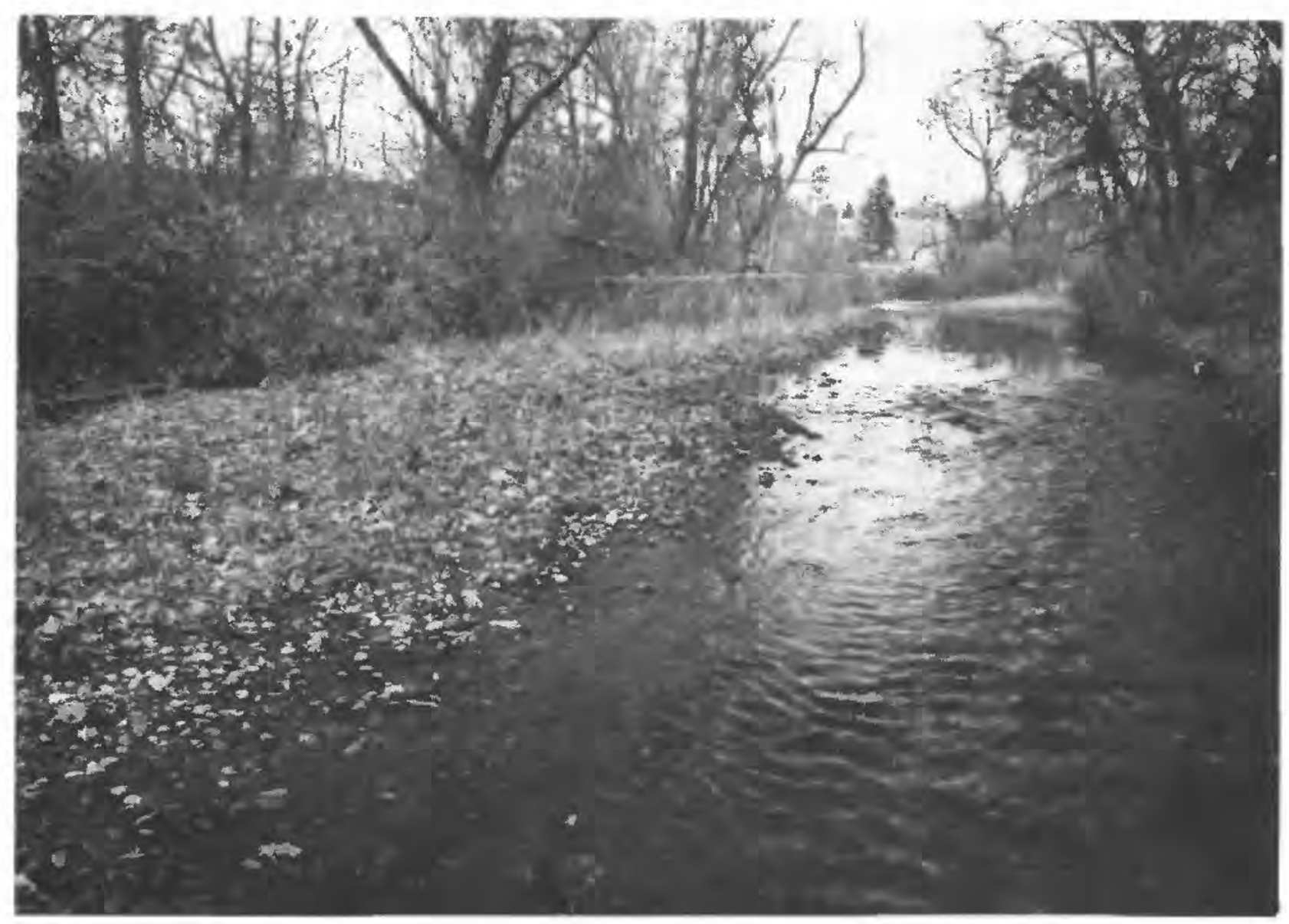

View from cross section 2, facing upstream toward right bank. Hydrographer is near section 1.

Figure A2-3. Moordener Kill at Castleton-on-Hudson, N.Y. A. Photographs during late fall. Hydrographer is holding a stadia rod at approximate water-surface elevation of the maximum recorded discharge. 


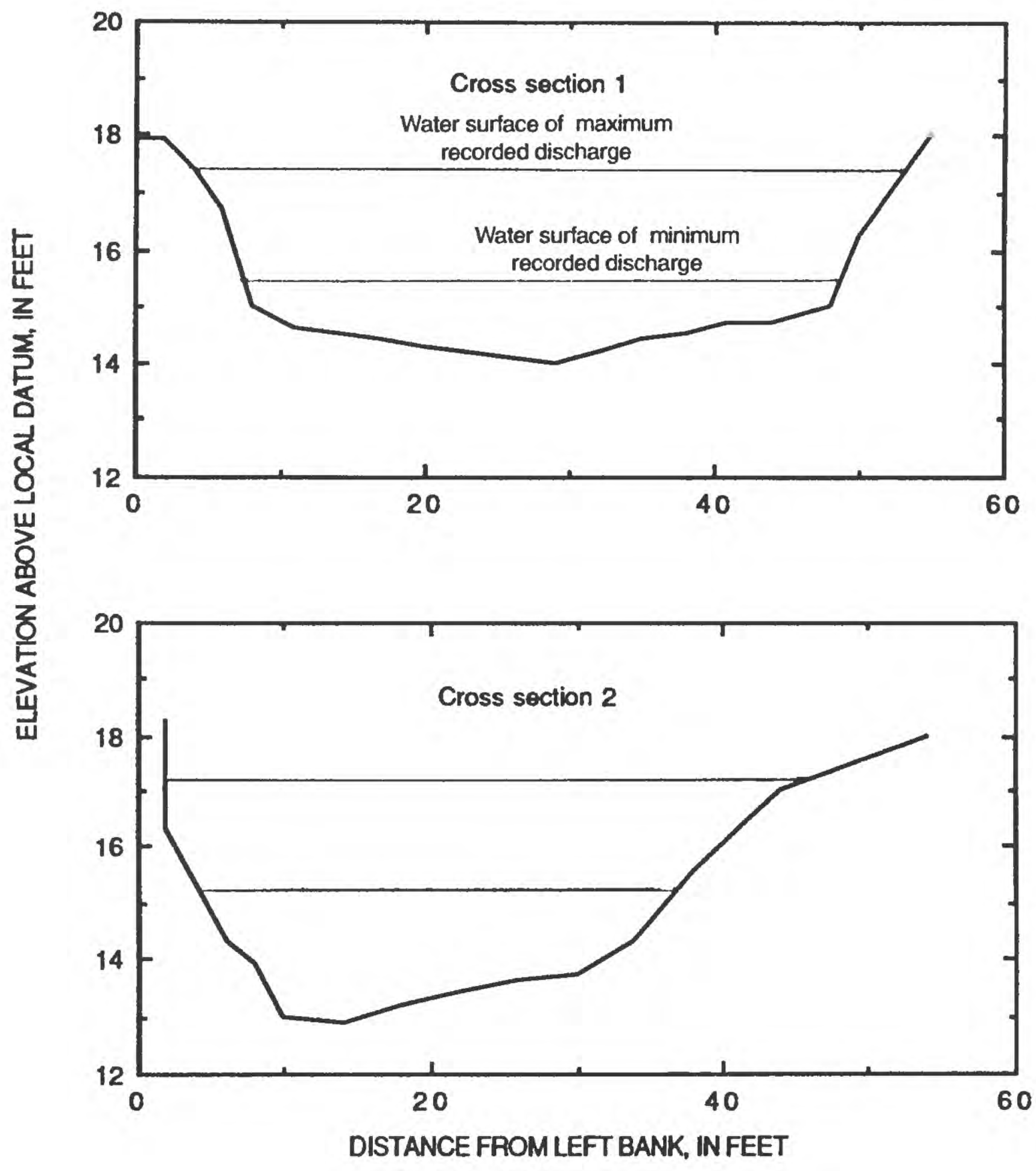

Figure A2-3. Moordener Kill at Castleton-on-Hudson, N.Y. (continued). B. Cross sections. (Locations are shown in plan view on p. 55.) 
PLAN VIEW (not to scale)

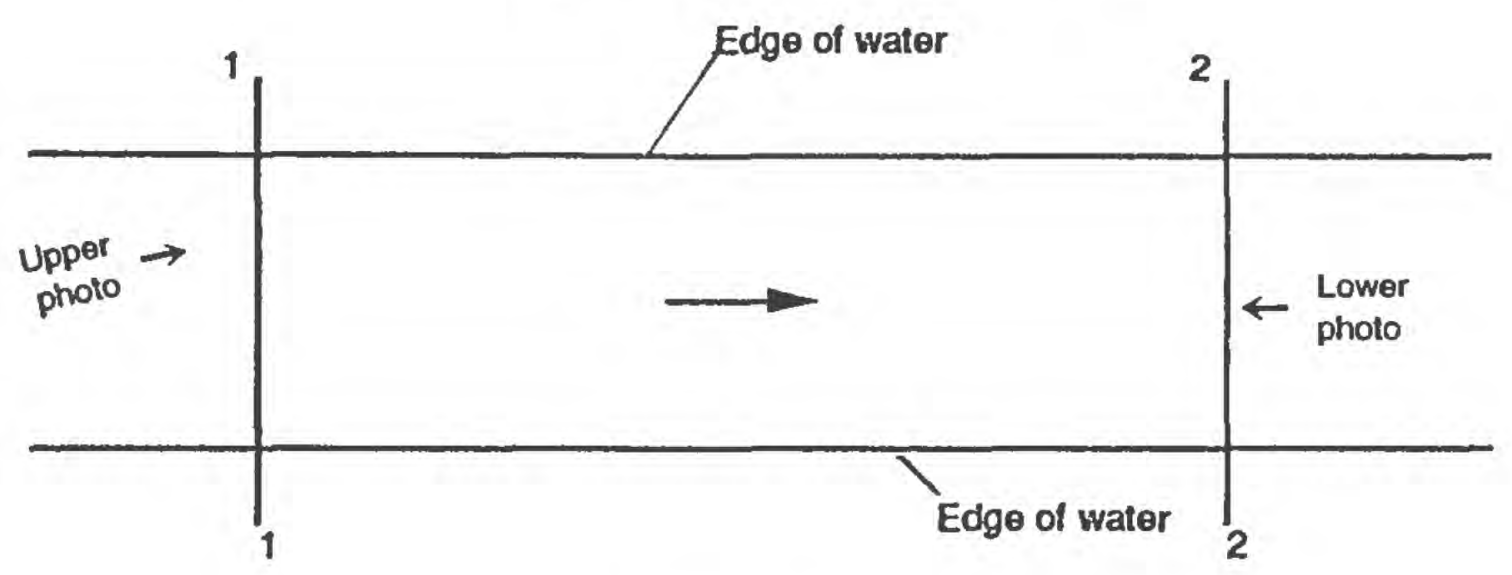

\section{EXPLANATION}
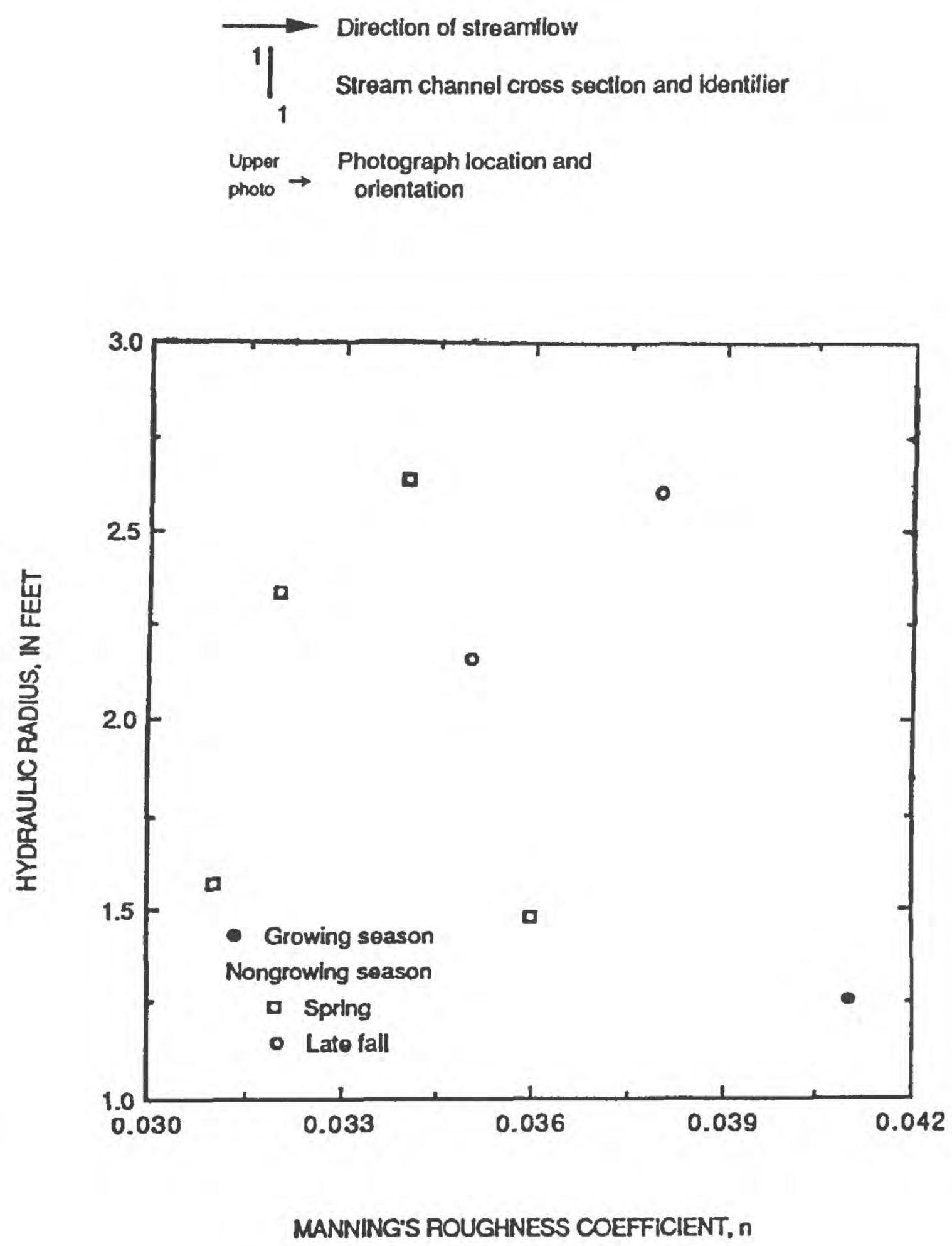

Figure A2-3. Moordener Kill at Castleton-on-Hudson, N.Y. (continued). C. Plan view and relation between hydraulic radius and Manning's roughness coefficient during growing and nongrowing seasons. 


\section{SITE 4. CANISTEO RIVER AT ARKPORT, N.Y.}

Table A2-4. Station description and hydraulic data

Location.--Latitude $42^{\circ} 23^{\prime} 45^{\prime \prime}$, longitude $77^{\circ} 42^{\prime} 42^{\prime \prime}$, Steuben County, on left bank 0.2 mi downstream from Arkport Dam, and $0.9 \mathrm{mi}$ west of Arkport. A 3-section, 269-ft-long reach; section 1 is about $430 \mathrm{ft}$ upstream from gage.

USGS station-identification number.--01521500.

Drainage area.--30.6 $\mathrm{mi}^{2}$.

Bed material.--Small cobbles, mostly flat. Intermediate diameter $\mathrm{d}_{50}=0.32$ and $\mathrm{d}_{84}=0.49 \mathrm{ft}$. Minimum diameter $\mathrm{d}_{50}=0.09 \mathrm{ft}$.

Bank descriptions.--Both banks have brush and a few trees, 0.5 to $2.0 \mathrm{ft}$ in diameter and spaced 20 to $50 \mathrm{ft}$ apart. The brush is denser on the left bank than on the right. Both banks have exposed tree roots. Vegetation indices: $1.5,2.5$.

Remarks.--Flows exceeding $500 \mathrm{ft}^{3} / \mathrm{s}$ are controlled by detention in Arkport Reservoir. A fallen tree trunk, about $0.5 \mathrm{ft}$ in diameter, spans the channel between sections 2 and 3 . The effect of this obstruction on the computed $\mathrm{n}$ values for the highest recorded flows is considered minimal. The $\mathbf{n}$ values computed at this site are affected by streambank vegetation.

\section{Hydraulic Data}

$\left[\mathrm{ft}=\mathrm{fect} ; \mathrm{ft}^{2}=\right.$ square feet; $\mathrm{ft} / \mathrm{s}=$ feet per second; $\mathrm{ft}^{3} / \mathrm{s}=$ cubic feet per second. $]$

\begin{tabular}{|c|c|c|c|c|c|c|c|c|c|}
\hline \multirow[b]{2}{*}{$\begin{array}{c}\text { Discharge } \neq \\
\left(\mathrm{ft}^{3} / \mathrm{s}\right)\end{array}$} & \multicolumn{5}{|c|}{ Average values for reach } & \multirow[b]{2}{*}{$\begin{array}{c}\text { Water- } \\
\text { surface } \\
\text { slope }\end{array}$} & \multirow[b]{2}{*}{$\begin{array}{l}\text { Energy } \\
\text { gradient }\end{array}$} & \multirow{2}{*}{$\begin{array}{l}\text { Percent } \\
\text { wetted } \\
\text { perimeter } \\
\text { vegetated }\end{array}$} & \multirow[b]{2}{*}{$\underset{n}{\text { Manning's }}$} \\
\hline & $\begin{array}{l}\text { Area } \\
\left(\mathrm{ft}^{2}\right)\end{array}$ & $\begin{array}{l}\text { Width } \\
\text { (ft) }\end{array}$ & $\begin{array}{l}\text { Hydraulic } \\
\text { radius } \\
\text { (ft) }\end{array}$ & $\begin{array}{l}\text { Velocity } \\
\text { (ft/s) }\end{array}$ & $\begin{array}{l}\text { Froude } \\
\text { number }\end{array}$ & & & & \\
\hline${ }^{\mathrm{a}} 145$ & 57.2 & 30.2 & 1.84 & 2.57 & 0.33 & 0.00223 & 0.00233 & 19.6 & 0.042 \\
\hline *a 177 & 53.5 & 29.7 & 1.75 & 3.36 & .45 & .00216 & .00235 & 18.3 & .031 \\
\hline$b_{204}$ & 62.1 & 30.8 & 1.95 & 3.30 & .41 & .00286 & .00296 & 21.4 & .039 \\
\hline$b_{262}$ & 71.2 & 31.8 & 2.16 & 3.70 & .44 & .00264 & .00277 & 24.2 & .036 \\
\hline$b_{451}$ & 91.0 & 34.4 & 2.54 & 4.98 & .54 & .00256 & .00276 & 30.2 & .030 \\
\hline$b_{489}$ & 97.4 & 35.3 & 2.64 & 5.03 & .54 & .00309 & .00316 & 32.2 & .032 \\
\hline$* \mathrm{~b}_{489}$ & 99.5 & 35.8 & 2.67 & 4.93 & .52 & .00290 & .00300 & 33.0 & .032 \\
\hline$b_{505}$ & 103.0 & 36.4 & 2.70 & 4.94 & .52 & .00256 & .00274 & 34.2 & .031 \\
\hline$b_{511}$ & 96.0 & 35.2 & 2.62 & 5.34 & .57 & .00271 & .00290 & 31.9 & .029 \\
\hline$b_{517}$ & 102.0 & 36.3 & 2.70 & 5.07 & .53 & .00256 & .00275 & 34.0 & .030 \\
\hline$b_{517}$ & 104.0 & 36.5 & 2.73 & 4.98 & .52 & .00305 & .00312 & 34.4 & .033 \\
\hline$c_{522}$ & 108.0 & 37.4 & 2.78 & 4.83 & .50 & .00297 & .00308 & 36.1 & .034 \\
\hline$b_{564}$ & 108.0 & 37.2 & 2.77 & 5.27 & .55 & .00245 & .00267 & 35.7 & .029 \\
\hline$c_{576}$ & 109.0 & 37.5 & 2.80 & 5.27 & .54 & .00286 & .00301 & 36.2 & .031 \\
\hline *b $\mathrm{b}_{582}$ & 104.0 & 36.7 & 2.73 & 5.59 & .59 & .00279 & .00296 & 34.7 & .029 \\
\hline$*^{c} 600$ & 118.0 & 38.6 & 2.92 & 5.10 & .51 & .00305 & .00316 & 38.0 & .034 \\
\hline${ }^{*} c_{632}$ & 119.0 & 38.8 & 2.95 & 5.29 & .53 & .00294 & .00306 & 38.4 & .033 \\
\hline$*^{c} 671$ & 125.0 & 39.4 & 3.03 & 5.38 & .53 & .00301 & .00314 & 39.5 & .033 \\
\hline
\end{tabular}

* The data used for this n-valuc calculation were collected during the growing season.

$\$$ The $n$ value computed for this discharge and water-surface profile is affected by flow-area expansion of:

a greater than 20 percent;

b between 10 and 20 percent;

c less than 10 percent. 


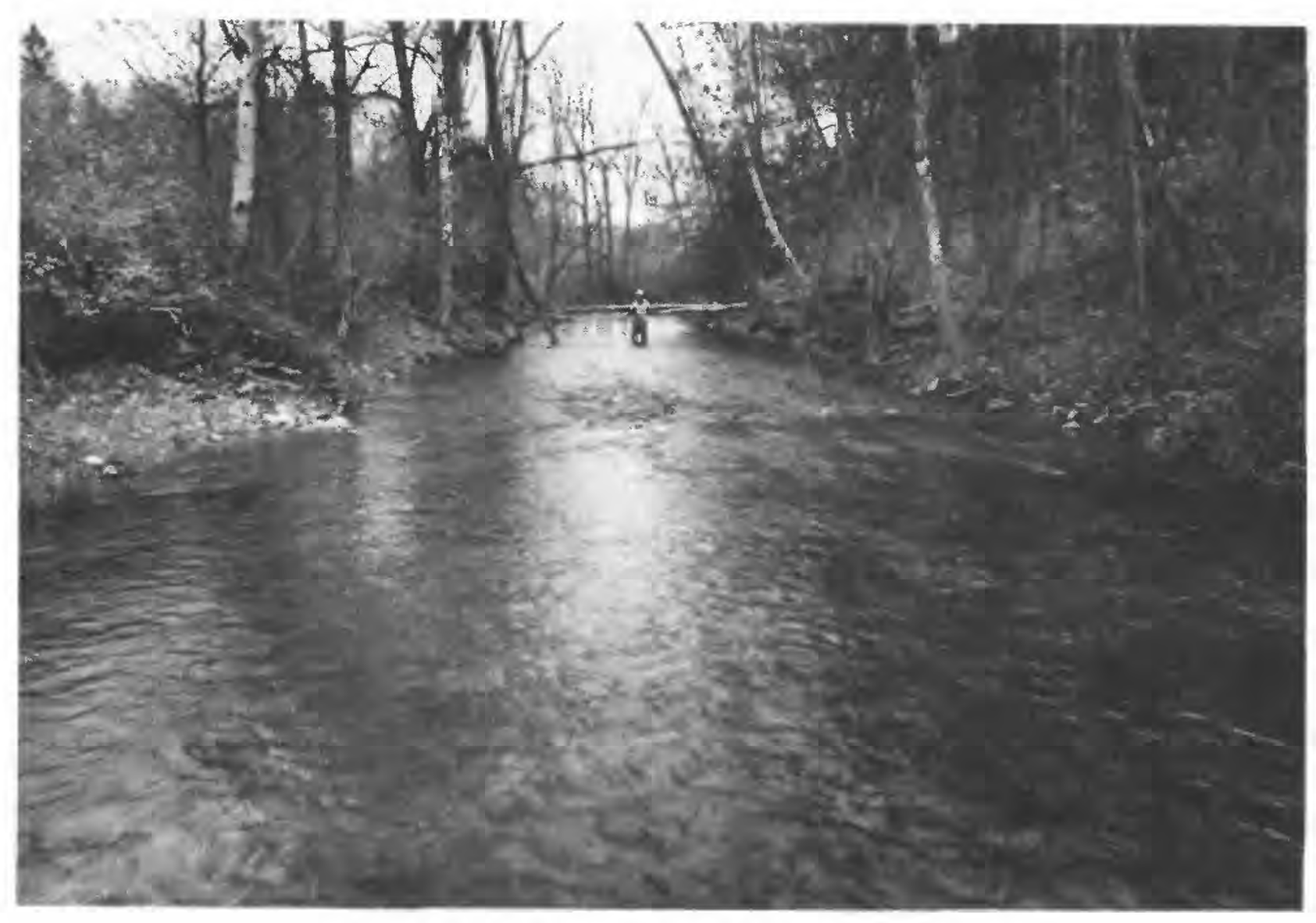

View from cross section 1, facing downstream.

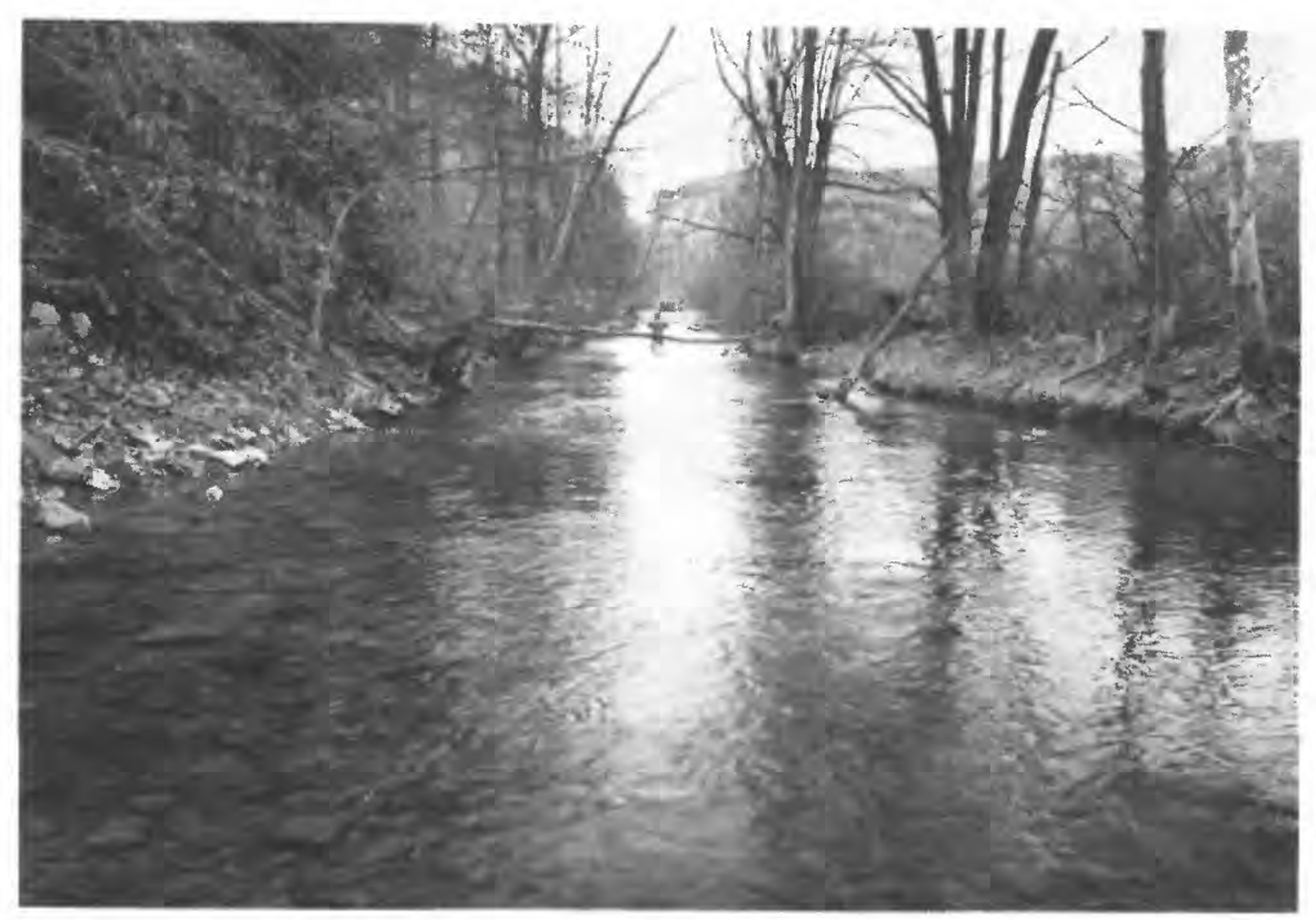

View from cross section 3, facing upstream.

Figure A2-4. Canisteo River at Arkport, N.Y. A. Photographs during late fall. Hydrographer is at section 2 holding a 15-foot rod at approximate water-surface elevation of maximum recorded discharge. 

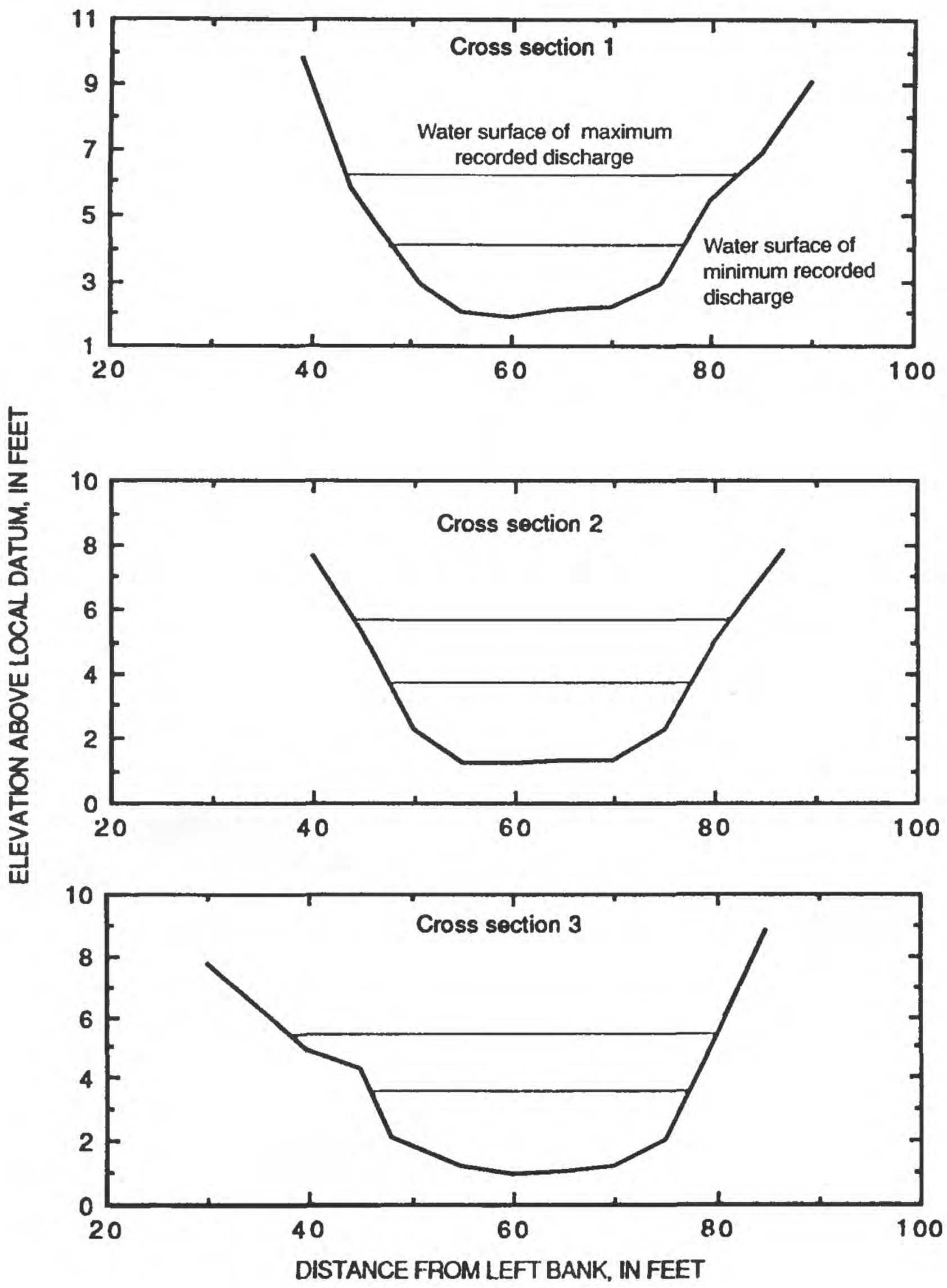

Figure A2-4. Canisteo River at Arkport, N.Y. (continued). B. Cross sections. (Locations are shown in plan view on p. 59.) 
PLAN VIEW (not to scale)

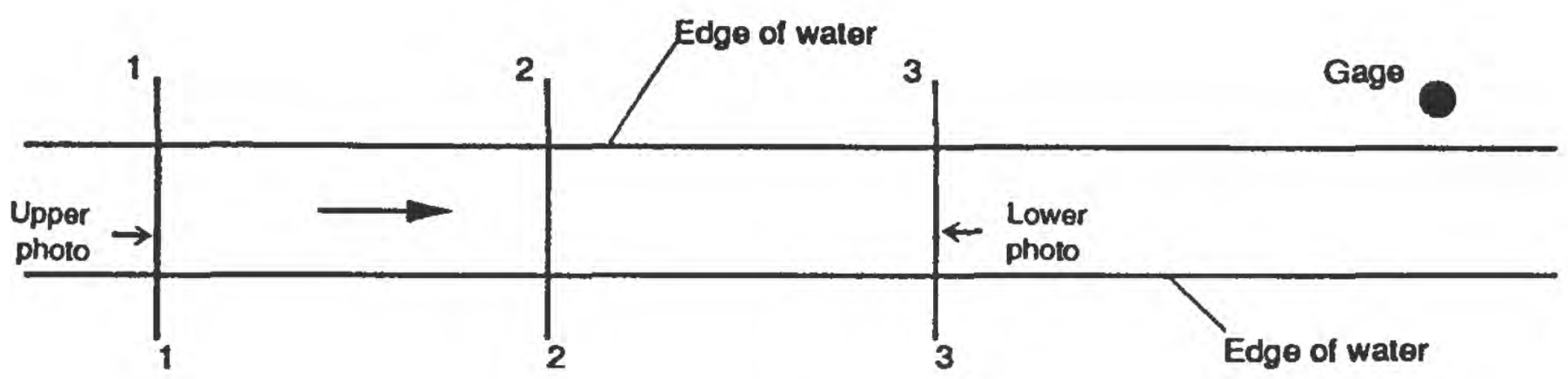

\section{EXPLANATION}

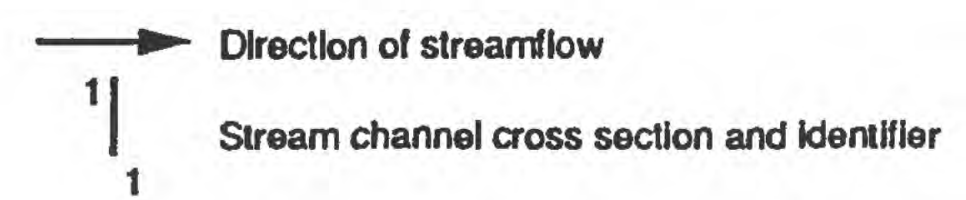

Upper Photograph location and photo $\rightarrow$ orientation

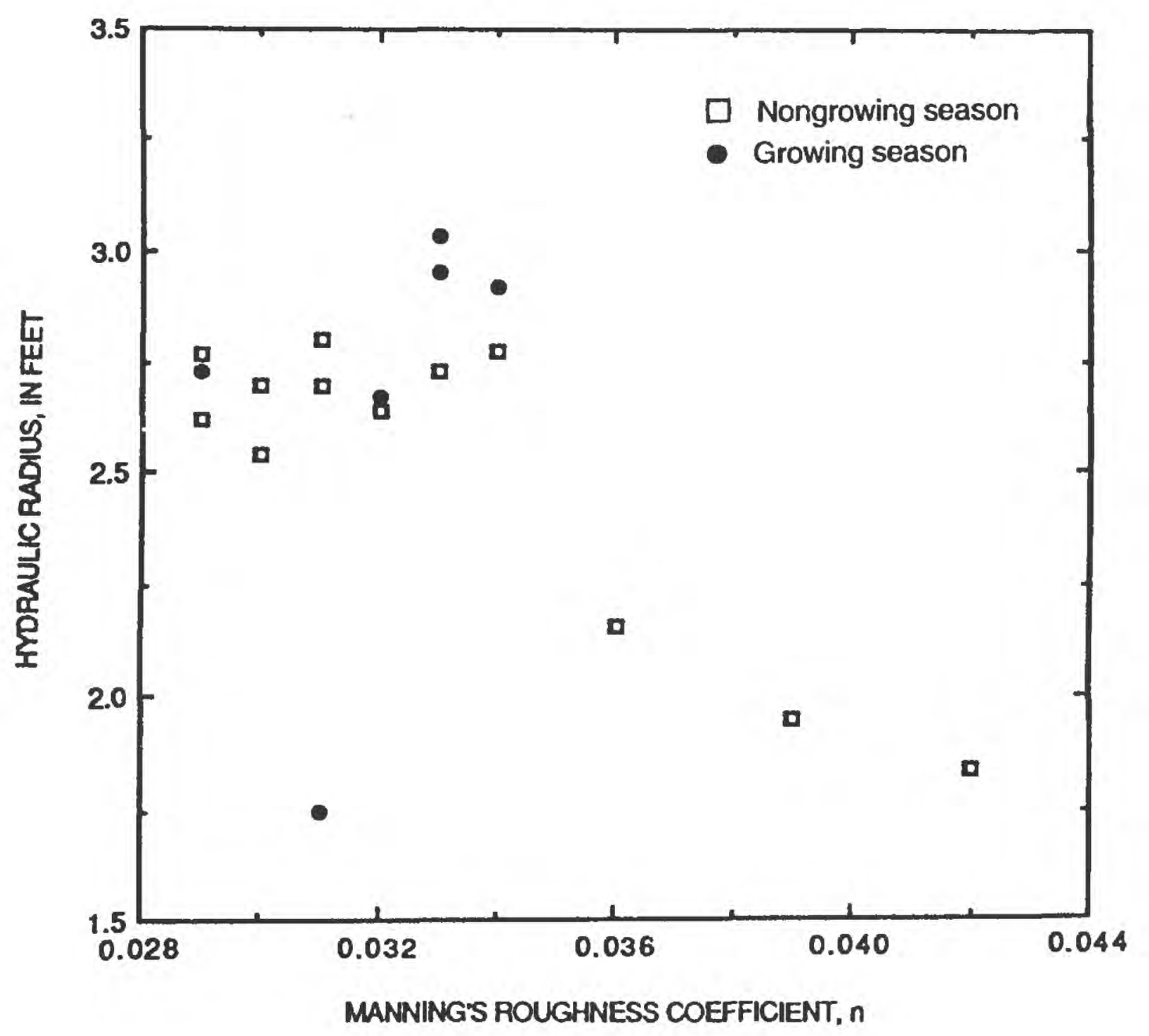

Figure A2-4. Canisteo River at Arkport, N.Y. (continued). C. Plan view and relation between hydraulic radius and Manning's roughness coefficient during growing and nongrowing seasons. 


\section{SITE 5. MILL BROOK NEAR DUNRAVEN, N.Y.}

Table A2-5. Station description and hydraulic data

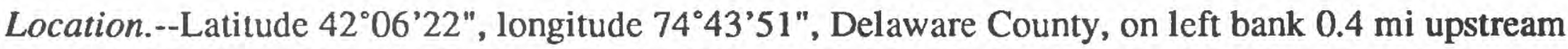
from bridge on New York City Road 9 and Pepacton Reservoir, and $2.7 \mathrm{mi}$ southwest of Dunraven. A 3-section, 227-ft-long reach; section 1 is about 0.2 mi upstream from bridge on New York City Road 9.

USGS station-identification number.--01414500.

Drainage area.--25.2 $\mathrm{mi}^{2}$.

Bed material.--Rounded or flat cobbles and boulders. Intermediate diameter $\mathrm{d}_{50}=0.45 \mathrm{ft}$ and $\mathrm{d}_{84}=0.91 \mathrm{ft}$. Minimum diameter $\mathrm{d}_{50}=0.14 \mathrm{ft}$.

Bank description.--Left bank has low overflow area covered with grassy hummocks; brush and large, rock rip-rap beyond. Right bank is gradually sloped, with grasses above low-water channel and scattered trees halfway up bank and beyond. Vegetation indices: 1,2 (low-overflow area not included).

Remarks.--The highest flow during the period of study was at a level below the point at which trees are found on the right bank. The percentages of wetted perimeter that are vegetated are high in comparison to those at other sites because the vegetated overflow area on the left bank is included in these values. The discharge record at this site during the study period is of fair to poor (rather than "good") accuracy.

\section{Hydraulic Data}

$\left[\mathrm{ft}=\mathrm{fcct} ; \mathrm{ft}^{2}=\right.$ square feet; $\mathrm{ft} / \mathrm{s}=$ feet per second; $\mathrm{ft}^{3} / \mathrm{s}=$ cubic feet per second. $]$

\begin{tabular}{|c|c|c|c|c|c|c|c|c|c|}
\hline \multirow[b]{2}{*}{$\begin{array}{c}\text { Discharge } \neq \\
\left(\mathrm{ft}^{3} / \mathrm{s}\right)\end{array}$} & \multicolumn{5}{|c|}{ Average values for reach } & \multirow[b]{2}{*}{$\begin{array}{c}\text { Water- } \\
\text { surface } \\
\text { slope }\end{array}$} & \multirow[b]{2}{*}{$\begin{array}{c}\text { Energy } \\
\text { gradient }\end{array}$} & \multirow[b]{2}{*}{$\begin{array}{c}\text { Percent } \\
\text { wetted } \\
\text { perimeter } \\
\text { vegetated }\end{array}$} & \multirow[b]{2}{*}{$\begin{array}{c}\text { Manning's } \\
n\end{array}$} \\
\hline & $\begin{array}{l}\text { Area } \\
\left(\mathrm{ft}^{2}\right)\end{array}$ & $\begin{array}{l}\text { Width } \\
\text { (ft) }\end{array}$ & $\begin{array}{l}\text { Hydraulic } \\
\text { radius } \\
\text { (ft) }\end{array}$ & $\begin{array}{c}\text { Velocity } \\
\text { (fl/s) }\end{array}$ & $\begin{array}{l}\text { Froude } \\
\text { number }\end{array}$ & & & & \\
\hline$\$ 109$ & 43.7 & 38.1 & 1.14 & 2.52 & 0.43 & 0.00991 & 0.00990 & 0 & 0.062 \\
\hline *169 & 63.4 & 43.4 & 1.38 & 2.67 & .44 & .01013 & .01015 & 15.6 & .069 \\
\hline$\$ 201$ & 61.3 & 43.0 & 1.37 & 3.30 & .50 & .01115 & .01095 & 13.1 & .057 \\
\hline${ }^{a} 217$ & 63.2 & 44.0 & 1.34 & 3.44 & .54 & .01040 & .01041 & 11.4 & .054 \\
\hline$f^{2} 809$ & 132 & 56.0 & 2.22 & 6.16 & .71 & .01035 & .01064 & 29.3 & .042 \\
\hline$\$ 1,720$ & 215 & 61.9 & 3.26 & 8.04 & .76 & .01000 & .01063 & 40.7 & .042 \\
\hline$\$ 2,500$ & 245 & 62.7 & 3.66 & 10.23 & .91 & .00978 & .01080 & 42.0 & .035 \\
\hline
\end{tabular}

$\$$ The $\mathrm{n}$ value computed for this discharge and water-surface profile is affected by 10 to 22 percent flow-area expansion in the reach.

* The data used for this n-value calculation were collected during the growing season.

a Data from the middle cross section were not available for computations for this water-surface profile. 


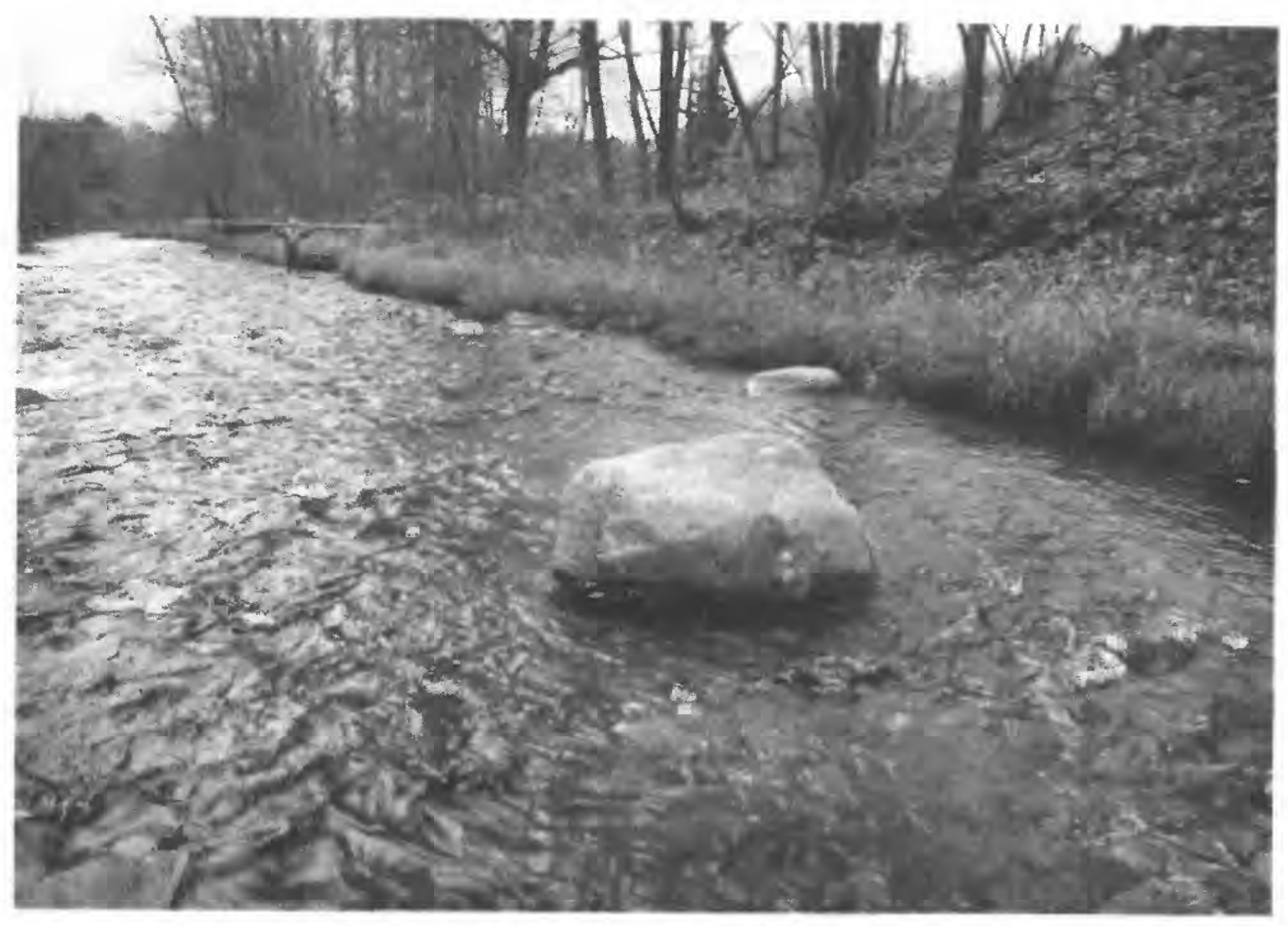

View from cross section 1, facing downstream toward right bank.

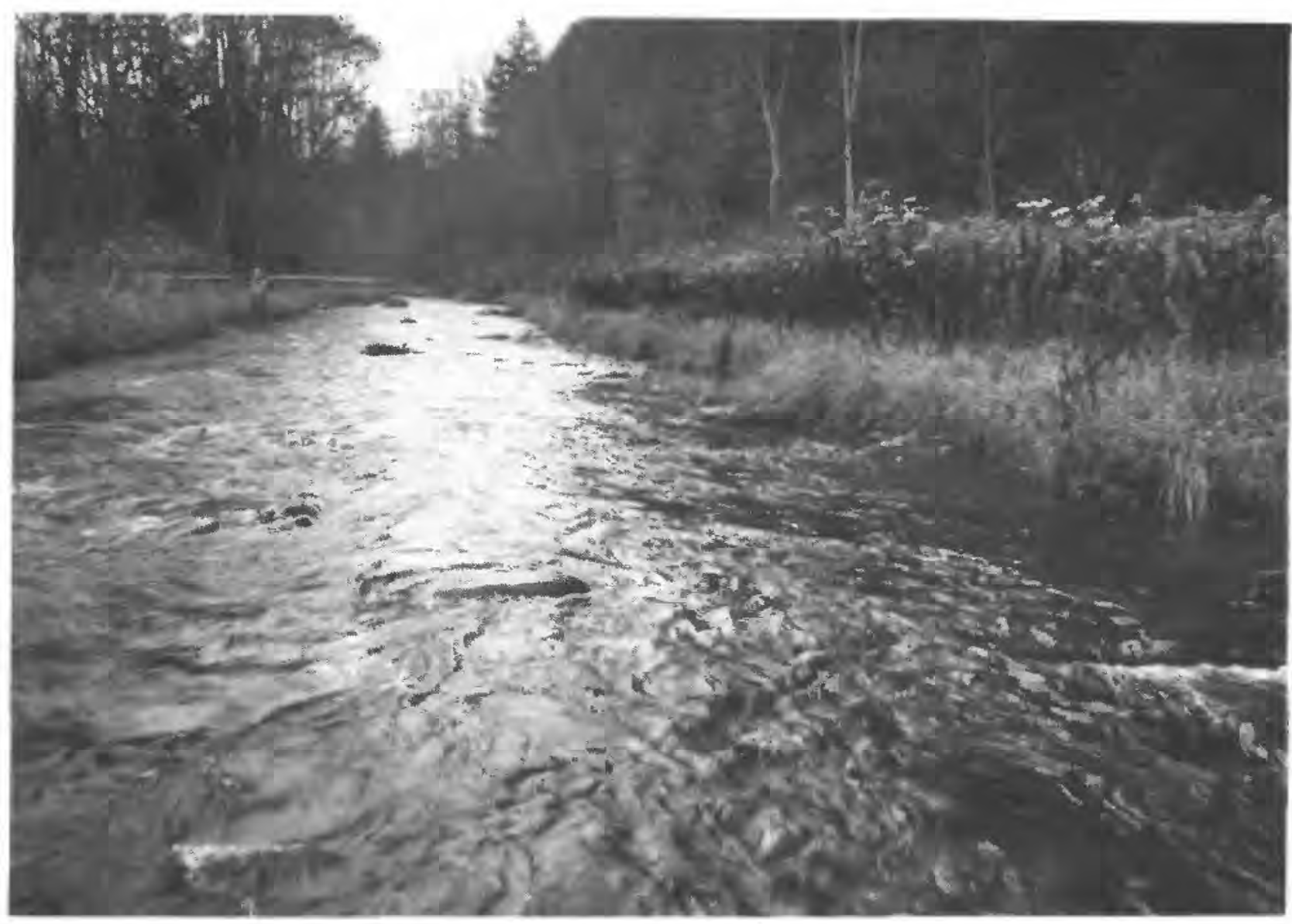

View from cross section 3, facing upstream toward left bank.

Figure A2-5. Mill Brook near Dunraven, N.Y. A. Photographs during late fall. Hydrographer is at section 2 holding a 25-foot rod at approximate water-surface elevation of maximum recorded discharge. 

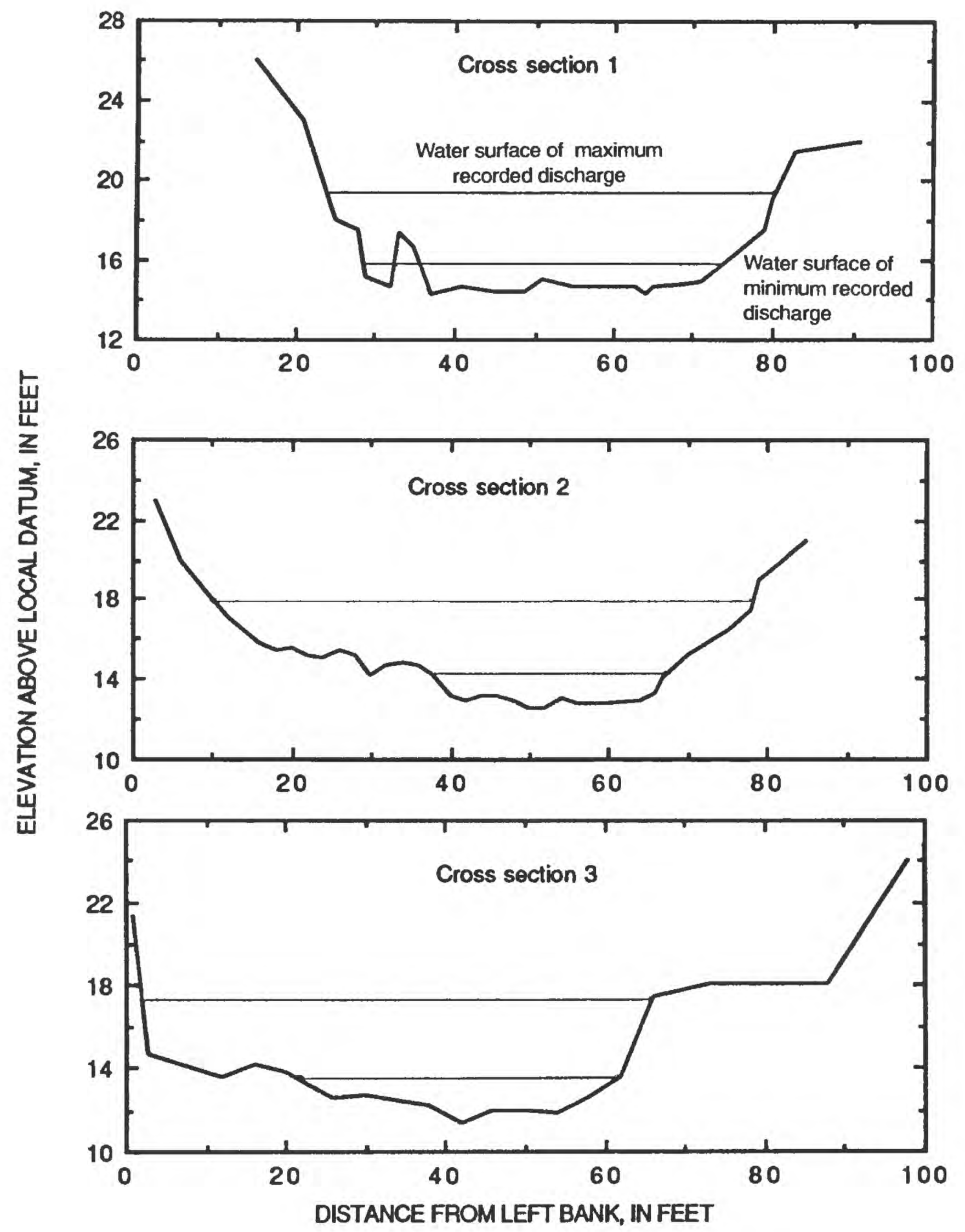

Figure A2-5. Mill Brook near Dunraven, N.Y. (continued). B. Cross sections. (Locations are shown in plan view on p. 63.) 
PLAN VIEW (not to scale)

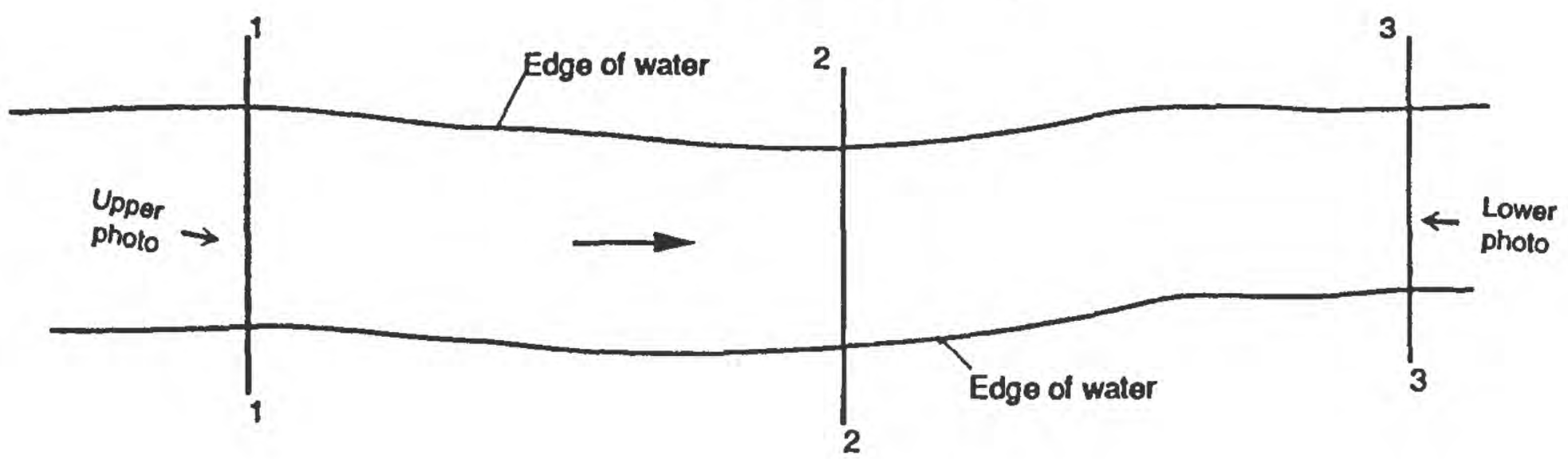

\section{EXPLANATION}
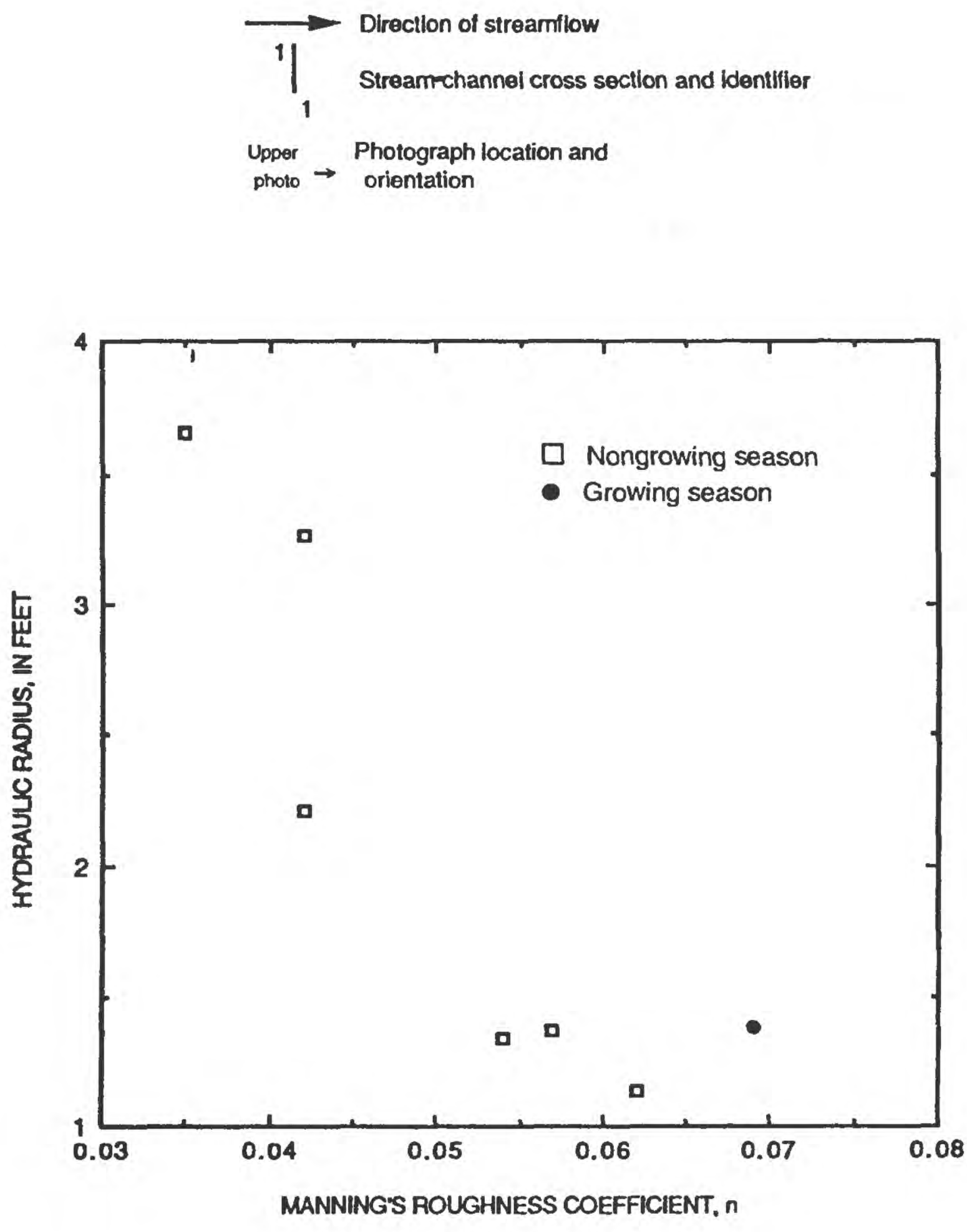

Figure A2-5. Mill Brook near Dunraven, N.Y. (continued). C. Plan view and relation between hydraulic radius and Manning's roughness coefficient during growing and nongrowing seasons. 


\section{SITE 6. EAST BRANCH AUSABLE RIVER AT AU SABLE FORKS, N.Y.}

Table A2-6. Station description and hydraulic data

Location.--Latitude $44^{\circ} 26^{\prime} 20^{\prime \prime}$, longitude $73^{\circ} 40^{\prime} 55^{\prime \prime}$, Essex County, on left bank $700 \mathrm{ft}$ upstream from bridge on Burt Street in Au Sable Forks, and 0.5 mi upstream from confluence with West Branch.

A 2-section, 202-ft-long reach is about $0.5 \mathrm{mi}$ upstream from gage.

USGS station-identification number.--04275000.

Drainage area.--198 $\mathrm{mi}^{2}$.

Bed material.--Cobbles and boulders as much as $7 \mathrm{ft}$ in diameter. Intermediate diameter $\mathrm{d}_{50}=1.0$ and $\mathrm{d}_{84}=2.5 \mathrm{ft}$. Minimum diameter $\mathrm{d}_{50}=0.60 \mathrm{ft}$.

Bank description.--Both banks are vegetated with dense woody brush, annual plants, grass, and trees

0.5 to $1.5 \mathrm{ft}$ in diameter. Trees are smaller and more densely spaced (about $50 \mathrm{ft}$ apart) on left bank than on the right. Vegetation indices: $2.5,3$.

Previous n-value computation.--The roughness coefficient was computed for the flood of March 31 ,

1951 at a site on this stream about 0.25 mi upstream of the study site. The data for that computation, taken from Barnes (1967), are included in the following table.

Remarks.--The $\mathrm{n}$ values computed at this site are presumed to be affected by streambank vegetation.

\section{Hydraulic Data}

[ $\mathrm{ft}=\mathrm{feet} ; \mathrm{ft}^{2}=$ square feet; $\mathrm{ft} / \mathrm{s}=$ feet per second; $\mathrm{ft}^{3} / \mathrm{s}=$ cubic feet per second.]

\begin{tabular}{|c|c|c|c|c|c|c|c|c|c|}
\hline \multirow[b]{2}{*}{$\begin{array}{c}\text { Discharge } \\
\left(\mathrm{ft}^{3} / \mathrm{s}\right)\end{array}$} & \multicolumn{5}{|c|}{ Average values for reach } & \multirow[b]{2}{*}{$\begin{array}{l}\text { Water- } \\
\text { surface } \\
\text { slope }\end{array}$} & \multirow[b]{2}{*}{$\begin{array}{l}\text { Energy } \\
\text { gradient }\end{array}$} & \multirow[b]{2}{*}{$\begin{array}{c}\text { Percent } \\
\text { wetted } \\
\text { perimeter } \\
\text { vegetated }\end{array}$} & \multirow[b]{2}{*}{$\begin{array}{c}\text { Manning's } \\
\text { n }\end{array}$} \\
\hline & $\begin{array}{l}\text { Area } \\
\left(\mathrm{ft}^{2}\right)\end{array}$ & $\begin{array}{l}\text { Width } \\
\text { (ft) }\end{array}$ & $\begin{array}{l}\text { Hydraulic } \\
\text { radius } \\
\text { (ft) }\end{array}$ & $\begin{array}{c}\text { Velocity } \\
(\mathrm{ft} / \mathrm{s})\end{array}$ & $\begin{array}{l}\text { Froude } \\
\text { number }\end{array}$ & & & & \\
\hline 3,790 & 673 & 177 & 3.60 & 5.64 & 0.52 & 0.00861 & 0.00826 & 30.5 & 0.056 \\
\hline 4,210 & 730 & 188 & 3.73 & 5.78 & .52 & .00871 & .00835 & 33.7 & .056 \\
\hline$* 5,720$ & 907 & 209 & 4.18 & 6.31 & .53 & .00842 & .00818 & 40.4 & .055 \\
\hline 6,290 & 978 & 213 & 4.42 & 6.44 & .53 & .00856 & .00831 & 41.2 & .057 \\
\hline 8,790 & 1,230 & 224 & 5.32 & 7.13 & .53 & .00797 & .00795 & 44.0 & .057 \\
\hline 10,800 & 1,400 & 230 & 5.85 & 7.74 & .55 & .00822 & .00815 & 45.4 & .056 \\
\hline${ }^{\mathrm{a}} 7,790$ & 1,070 & 152 & 6.72 & 7.26 & .48 & .00562 & -... & -- & .055 \\
\hline
\end{tabular}

* The data used for this n-value calculation were collected during the growing season.

${ }^{a}$ From Barnes (1967). 


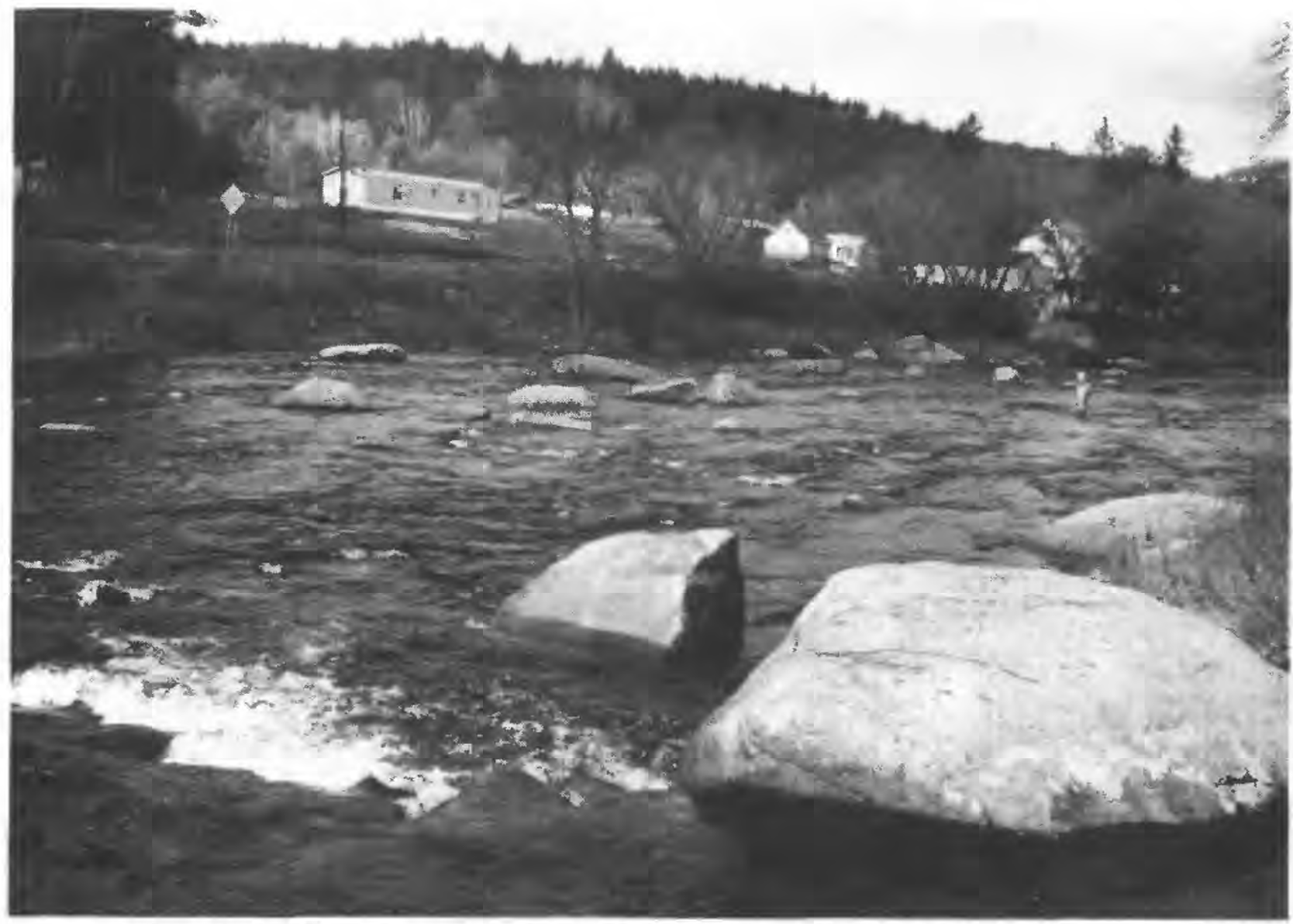

View from above cross section 1, facing downstream and across the channel. Hydrographer is at section 2.

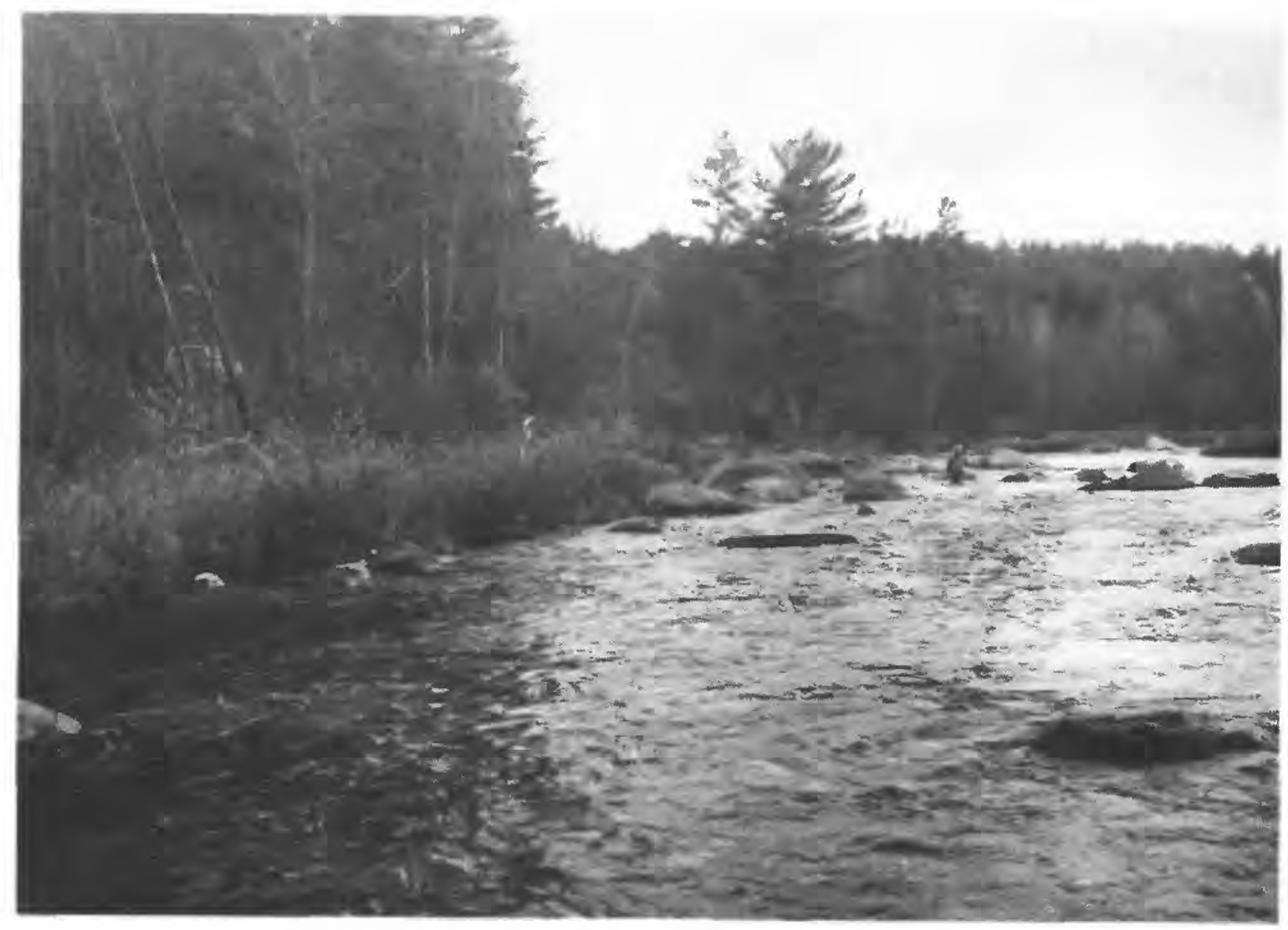

View from below cross section 2, facing upstream along right bank. Hydrographer is at section 1.

Figure A2-6. East Branch Ausable River at Ausable Forks, N.Y. A. Photographs during late fall. 

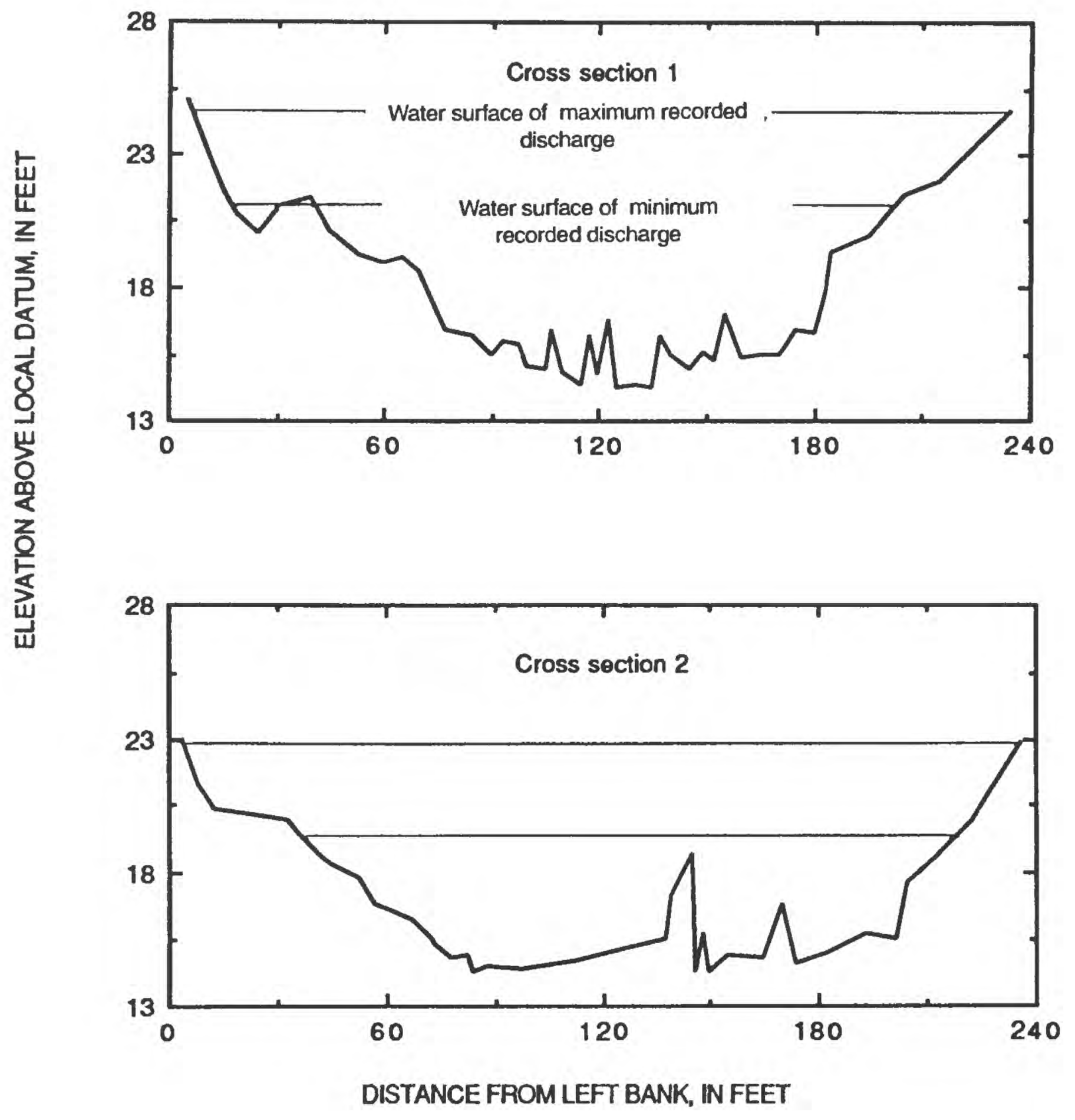

Figure A2-6. East Branch Ausable River at Ausable Forks, N.Y. (continued). B. Cross sections. (Locations are shown in plan view on p. 67.) 
PLAN VIEW (not to scale)

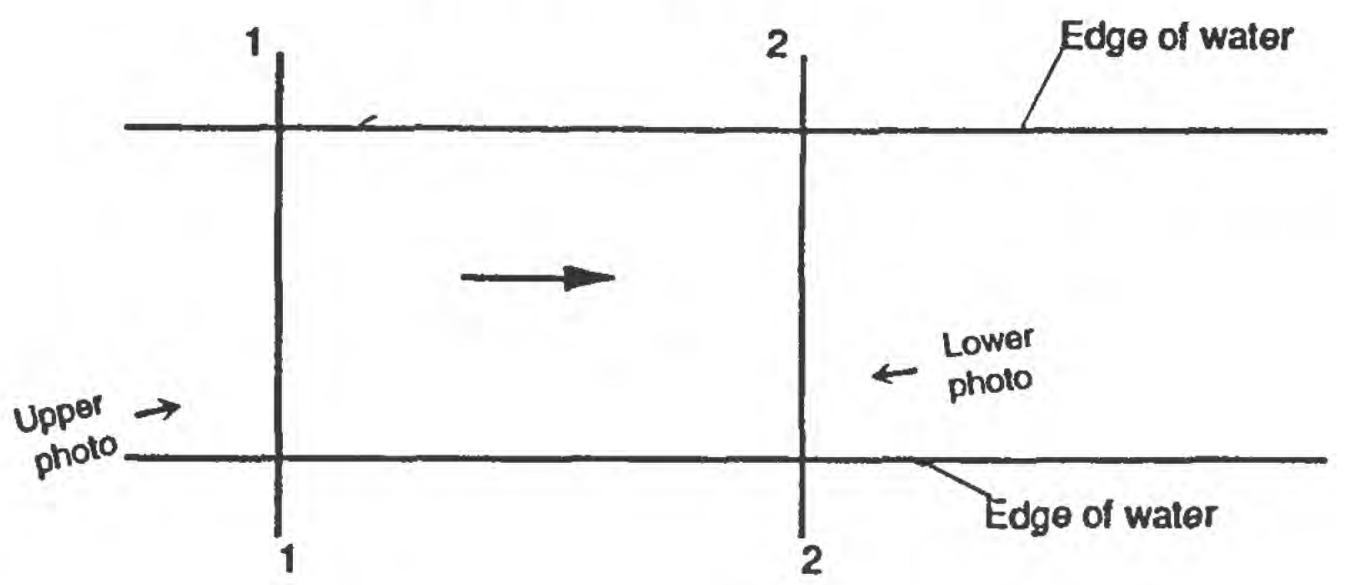

\section{EXPLANATION}
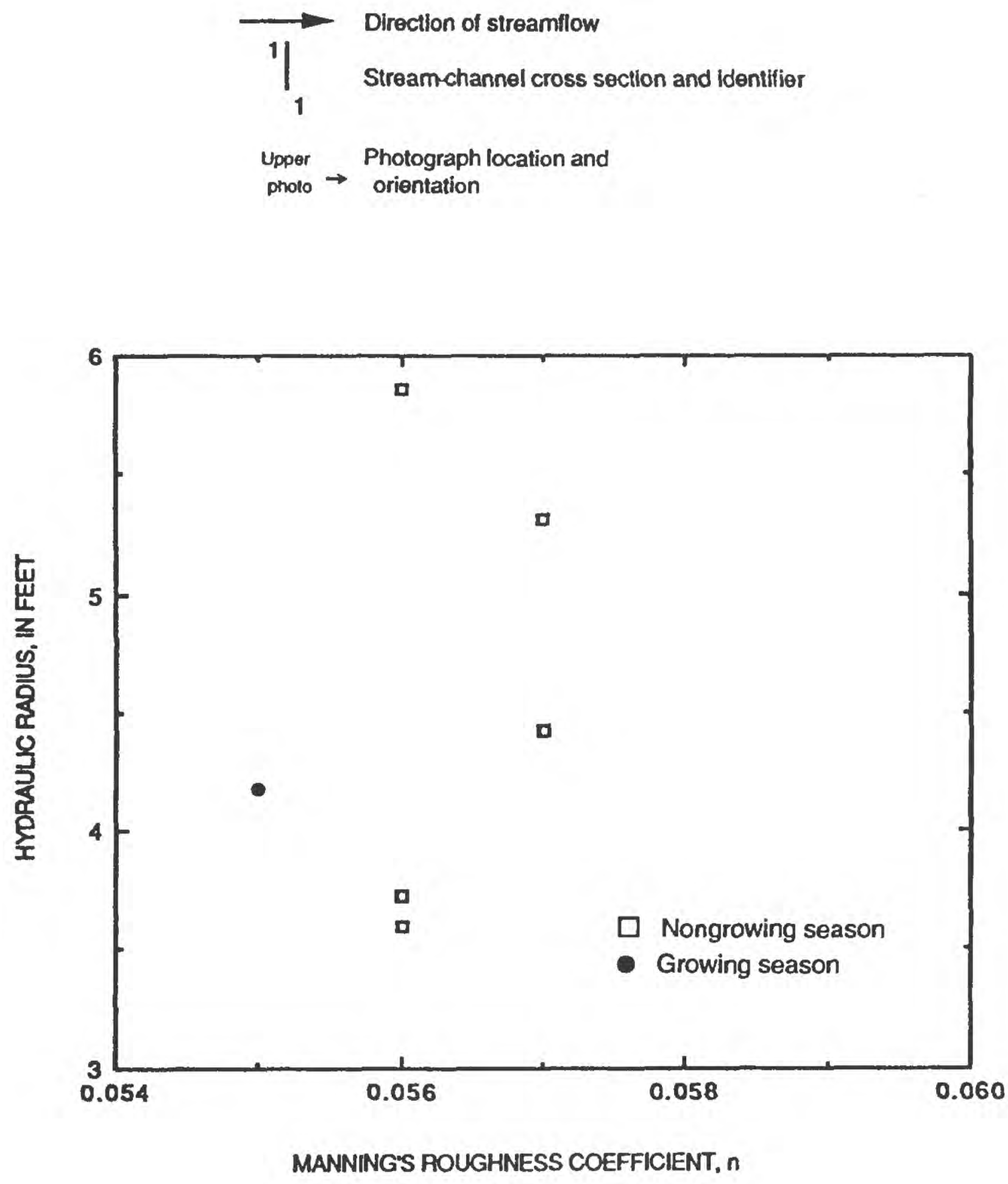

Figure A2-6. East Branch Ausable River at Ausable Forks, N.Y. (continued). C. Plan view and relation between hydraulic radius and Manning's roughness coefficient during growing and nongrowing seasons. 


\section{SITE 7. BEAVER KILL AT COOKS FALLS, N.Y.}

\section{Table A2-7. Station description and hydraulic data}

Location.--Latitude $41^{\circ} 56^{\prime} 47^{\prime \prime}$, longitude $74^{\circ} 58^{\prime} 48^{\prime \prime}$, Delaware County, on left bank $66 \mathrm{ft}$ downstream from road bridge in Cooks Falls, and 5.5 mi downstream from Willowemoc Creek. A 3-section, 569 -ft-long reach is $0.5 \mathrm{mi}$ upstream from bridge in Cooks Falls.

USGS station-identification number.--01420500.

Drainage area.--241 $\mathrm{mi}^{2}$.

Bed material.--Rounded cobbles and boulders. Intermediate diameter $\mathrm{d}_{50}=0.78 \mathrm{ft}$ and $\mathrm{d}_{84}=1.70 \mathrm{ft}$. Minimum diameter $\mathrm{d}_{50}=0.30 \mathrm{ft}$.

Bank description.--Left bank is steep and has boulders, cobbles, and scattered trees of varying sizes. Tree density is greater on left bank than on right. Dense woody brush, willow saplings, and grasses cover low right bank. A few trees with diameters ranging from 0.5 to $2.0 \mathrm{ft}$, occupy the high right bank. Vegetation indices: 2, 3.

Previous $n$-value computation.--The roughness coefficient was computed for the flood of March 22 , 1948 at a site on this stream about $0.5 \mathrm{mi}$ downstream of the gage and $1.0 \mathrm{mi}$ downstream of the study site. The data for that computation, taken from Barnes (1967), are included in the following table.

\section{Hydraulic Data}

$\left[\mathrm{ft}=\mathrm{fcet} ; \mathrm{ft}^{2}=\right.$ square feet; $\mathrm{ft} / \mathrm{s}=$ feet per second; $\mathrm{ft}^{3} / \mathrm{s}=$ cubic feet per second. $]$

\begin{tabular}{|c|c|c|c|c|c|c|c|c|c|}
\hline \multirow[b]{2}{*}{$\begin{array}{c}\text { Discharge } \neq \\
\left(\mathrm{ft}^{3} / \mathrm{s}\right)\end{array}$} & \multicolumn{5}{|c|}{ Average values for reach } & \multirow[b]{2}{*}{$\begin{array}{c}\text { Water- } \\
\text { surface } \\
\text { slope }\end{array}$} & \multirow[b]{2}{*}{$\begin{array}{c}\text { Energy } \\
\text { gradient }\end{array}$} & \multirow[b]{2}{*}{$\begin{array}{c}\text { Percent } \\
\text { wetted } \\
\text { perimeter } \\
\text { vegetated }\end{array}$} & \multirow[b]{2}{*}{$\begin{array}{c}\text { Manning's } \\
n\end{array}$} \\
\hline & $\begin{array}{l}\text { Area } \\
\left(\mathrm{ft}^{2}\right)\end{array}$ & $\begin{array}{l}\text { Width } \\
\text { (ft) }\end{array}$ & $\begin{array}{l}\text { Hydraulic } \\
\text { radius } \\
\text { (ft) }\end{array}$ & $\begin{array}{c}\text { Velocity } \\
(\mathrm{ft} / \mathrm{s})\end{array}$ & $\begin{array}{l}\text { Froude } \\
\text { number }\end{array}$ & & & & \\
\hline$* 575$ & 276 & 174 & 1.58 & 2.09 & 0.29 & 0.00409 & 0.00406 & 0 & 0.062 \\
\hline 2,520 & 581 & 189 & 3.05 & 4.35 & .44 & .00417 & .00405 & 0 & .047 \\
\hline 4,970 & 824 & 199 & 4.11 & 6.03 & .52 & .00408 & .00397 & .5 & .040 \\
\hline$\$ 8,710$ & 1,160 & 208 & 5.50 & 7.52 & .56 & .00448 & .00432 & 5.2 & .041 \\
\hline$\$ 9,520$ & 1,200 & 209 & 5.68 & 7.93 & .58 & .00471 & .00445 & 5.7 & .040 \\
\hline$* \neq 10,100$ & 1,240 & 210 & 5.81 & 8.18 & .59 & .00439 & .00424 & 6.1 & .039 \\
\hline$\$ 10,500$ & 1,230 & 210 & 5.80 & 8.54 & .62 & .00455 & .00428 & 6.1 & .037 \\
\hline 19,800 & 1,710 & 219 & 7.66 & 11.61 & .73 & .00503 & .00466 & 10.3 & .034 \\
\hline 23,900 & 1,900 & 222 & 8.39 & 12.56 & .76 & .00511 & .00474 & 11.9 & .034 \\
\hline${ }^{\mathrm{a}} 15,500$ & 1,650 & 224 & 7.27 & 9.39 & .61 & .00338 & ---- & -- & .033 \\
\hline
\end{tabular}

$\$$ The $\mathrm{n}$ value computed for this discharge and water-surface profile is affected by flow over a low bank on the right side of the reach.

* The data used for this n-value calculation were collected during the growing season.

${ }^{a}$ From Barnes (1967). 


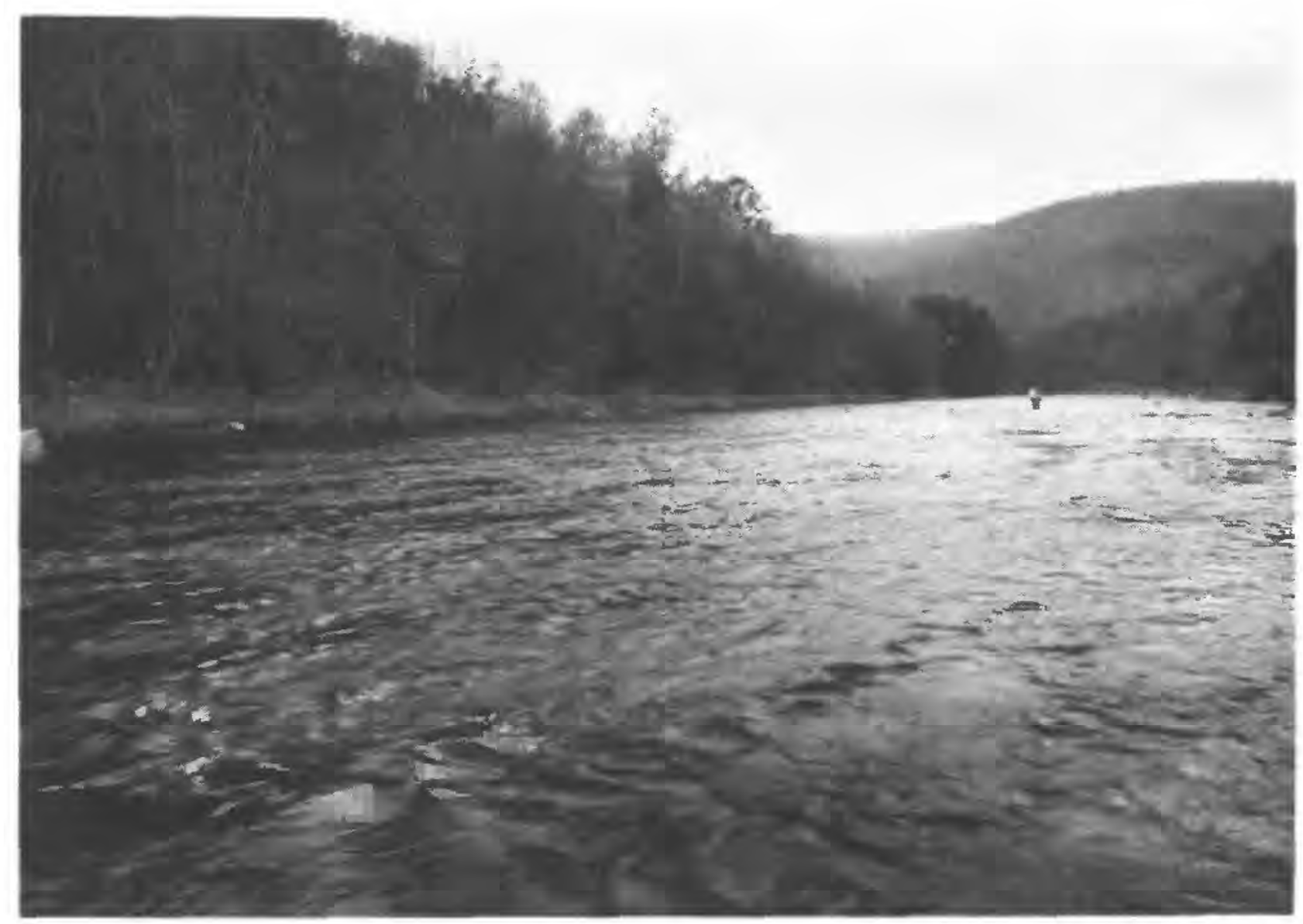

View from cross section 1, facing downstream toward left bank.

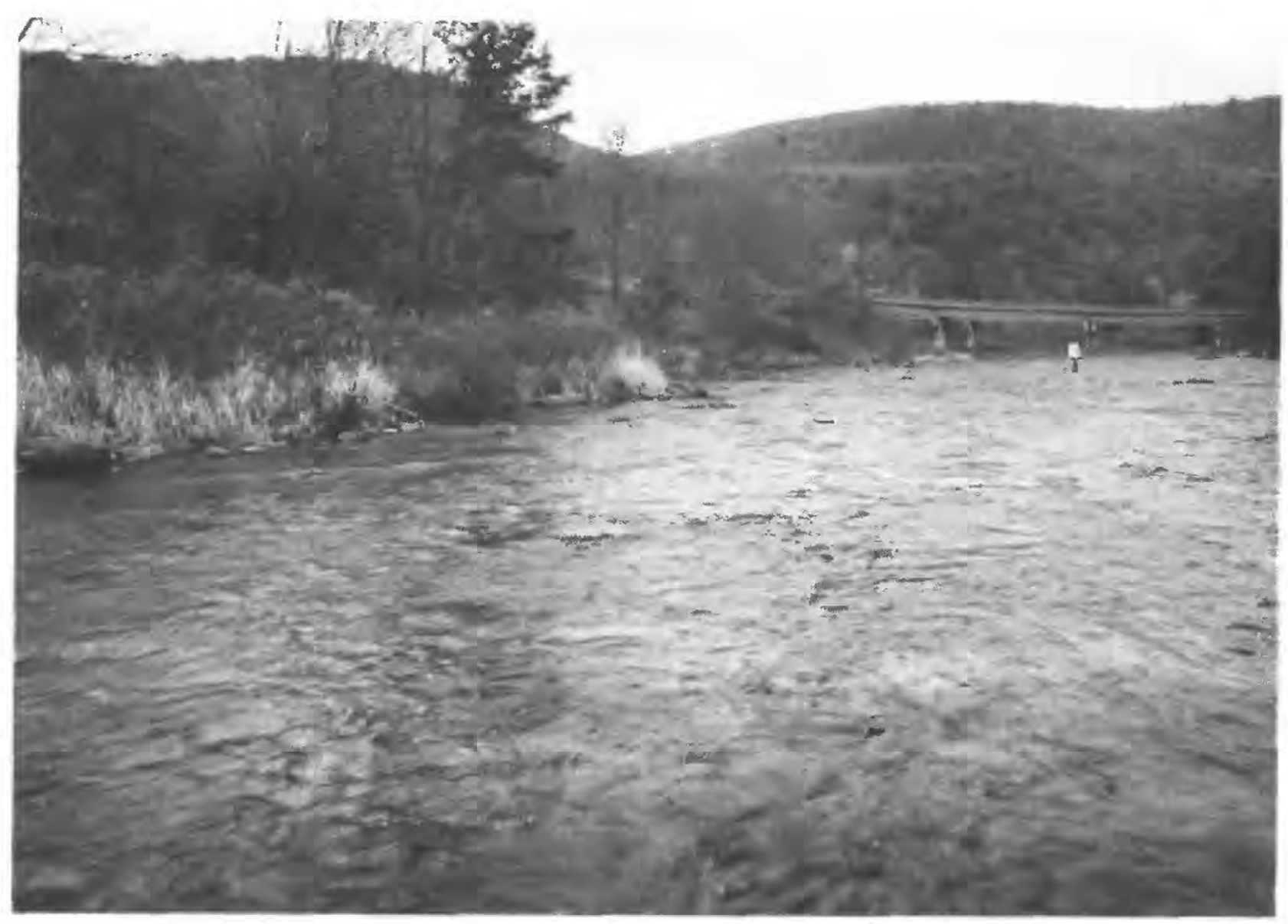

View from cross section 3, facing upstream toward right bank.

Figure A2-7. Beaver Kill at Cooks Falls, N.Y. A. Photographs during late fall. Hydrographer is at section 2. 


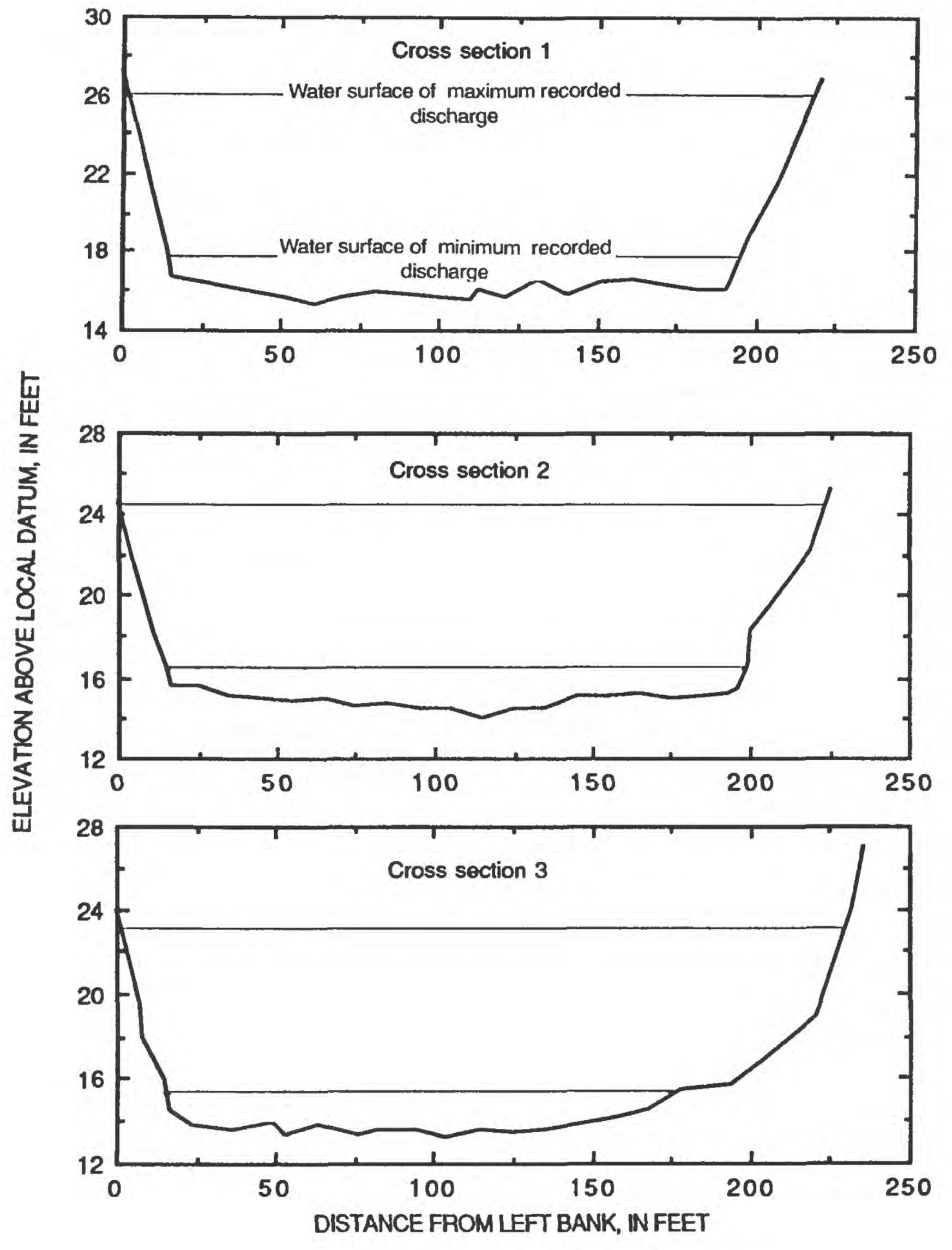

Figure A2-7. Beaver Kill at Cooks Falls, N.Y. (continued). B. Cross sections. (Locations are shown in plan view on p. 71.) 
PLAN VIEW (not to scale)

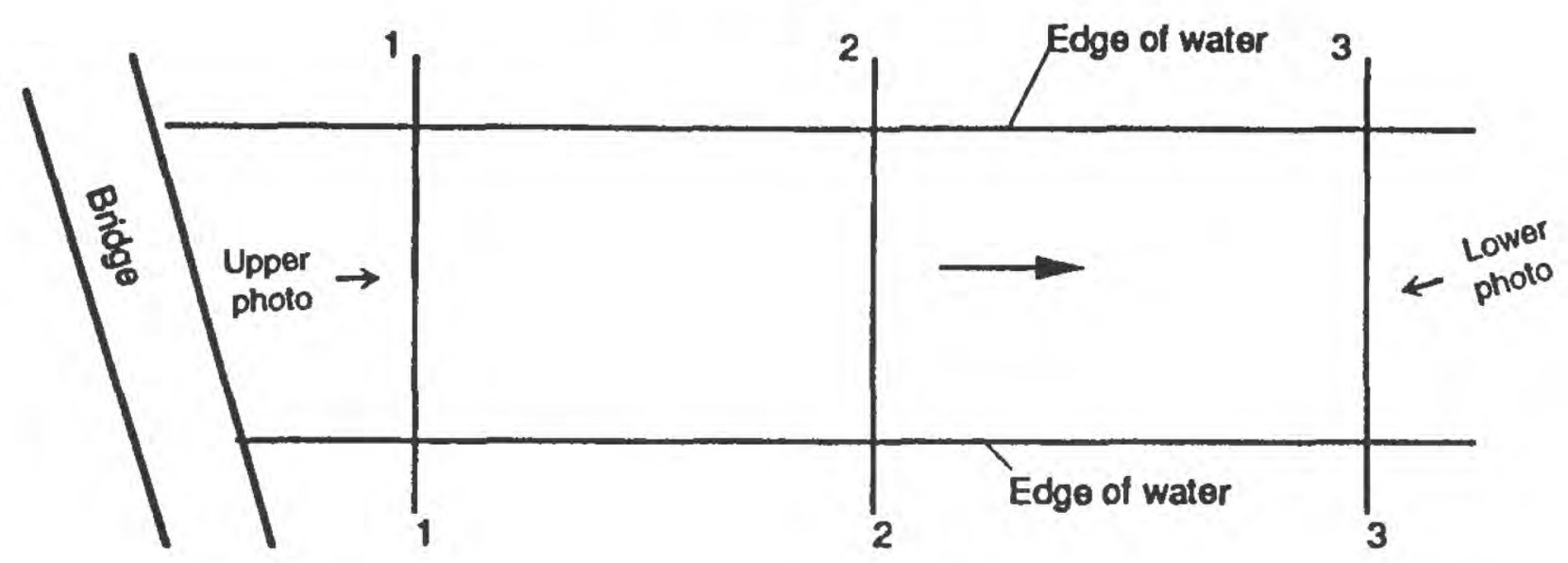

EXPLANATION
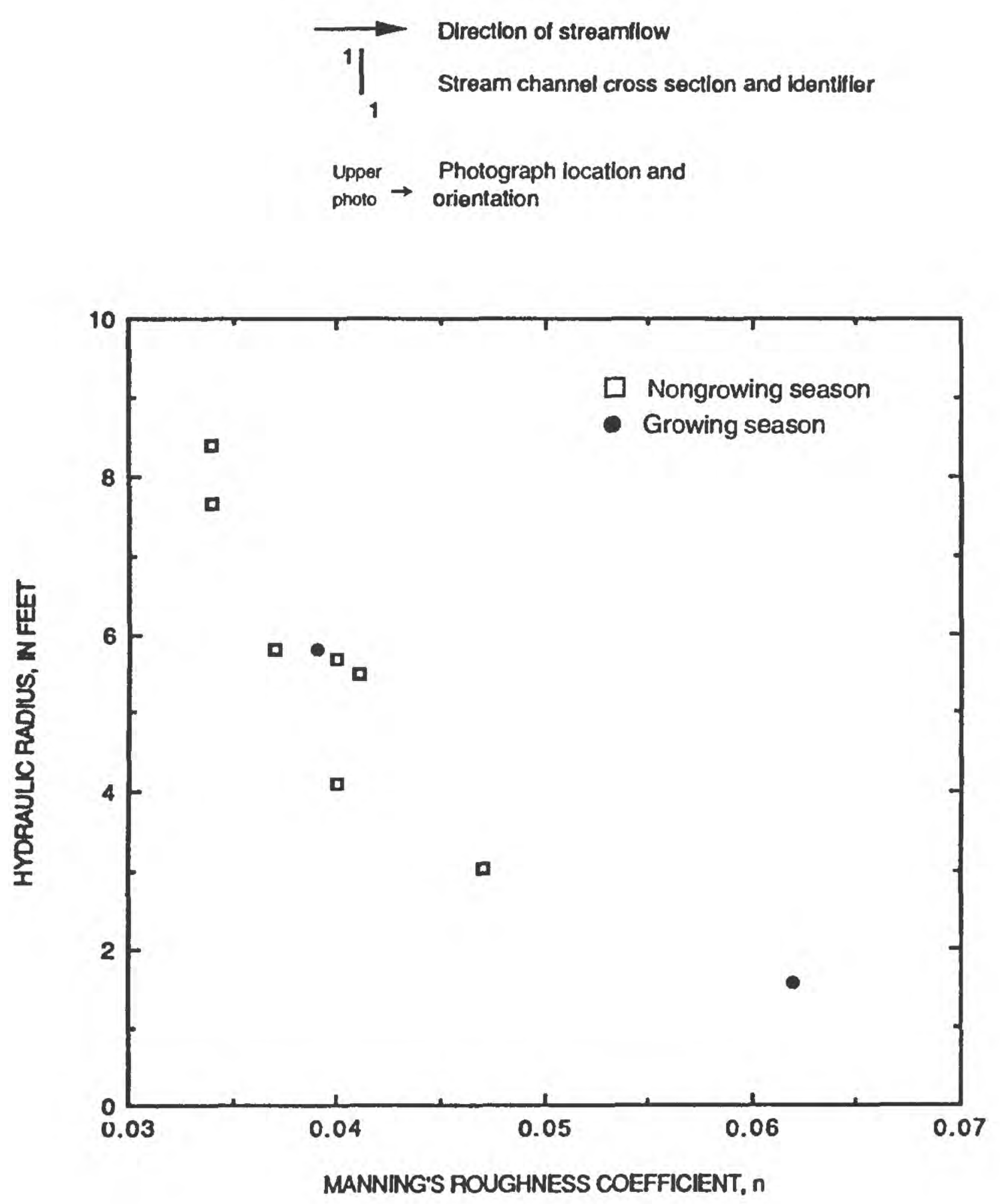

Figure A2-7. Beaver Kill at Cooks Falls, N.Y. (continued). C. Plan view and relation between hydraulic radius and Manning's roughness coefficient duning growing and nongrowing seasons. 


\section{SITE 8. ONONDAGA CREEK AT DORWIN AVENUE, SYRACUSE, N.Y.}

Table A2-8. Station description and hydraulic data

Location.--Latitude 42 $59^{\prime} 00^{\prime \prime}$, longitude 76 $09^{\prime} 04^{\prime \prime}$, Onondaga County, on left bank $550 \mathrm{ft}$ upstream from bridge on Dorwin Avenue, at Syracuse, and $4 \mathrm{mi}$ downstream from Onondaga Reservoir. A 2 -section, 265-ft-long reach; section 1 is $185 \mathrm{ft}$ downstream from bridge on Dorwin Ave.

USGS station-identification number.--04239000.

Drainage area. $--88.5 \mathrm{mi}^{2}$.

Bed material.--Gravel with small cobbles. Intermediate diameter $\mathrm{d}_{50}=0.13$ and $\mathrm{d}_{84}=0.21 \mathrm{ft}$. Minimum diameter $\mathrm{d}_{50}=0.07 \mathrm{ft}$.

Bank description.--This reach is a maintained grass-lined channel. Rip-rap lines the lower part of right bank. Vegetation indices: 0,0 .

Remarks.--High flows are controlled by detention in Onondaga Reservoir.

\section{Hydraulic Data}

$\left[\mathrm{ft}=\mathrm{fect} ; \mathrm{ft}^{2}=\right.$ square feet; $\mathrm{ft} / \mathrm{s}=$ feet per second; $\mathrm{ft}^{3} / \mathrm{s}=$ cubic feet per second. $]$

\begin{tabular}{|c|c|c|c|c|c|c|c|c|c|}
\hline \multirow[b]{2}{*}{$\begin{array}{c}\text { Discharge } \neq \\
\left(\mathrm{ft}^{3} / \mathrm{s}\right)\end{array}$} & \multicolumn{5}{|c|}{ Average values for reach } & \multirow[b]{2}{*}{$\begin{array}{l}\text { Water- } \\
\text { surface } \\
\text { slope }\end{array}$} & \multirow[b]{2}{*}{$\begin{array}{l}\text { Energy } \\
\text { gradient }\end{array}$} & \multirow[b]{2}{*}{$\begin{array}{l}\text { Percent } \\
\text { wetted } \\
\text { perimeter } \\
\text { vegetated }\end{array}$} & \multirow[b]{2}{*}{$\begin{array}{c}\text { Manning's } \\
n\end{array}$} \\
\hline & $\begin{array}{c}\text { Arca } \\
\left(\mathrm{ft}^{2}\right)\end{array}$ & $\begin{array}{l}\text { Width } \\
(\mathrm{ft})\end{array}$ & $\begin{array}{l}\text { Hydraulic } \\
\text { radius } \\
\text { (ft) }\end{array}$ & $\begin{array}{l}\text { Velocity } \\
(\mathrm{ft} / \mathrm{s})\end{array}$ & $\begin{array}{l}\text { Froude } \\
\text { number }\end{array}$ & & & & \\
\hline *387 & 124 & 65.2 & 1.88 & 3.16 & 0.41 & 0.00192 & 0.00163 & 5.0 & 0.029 \\
\hline 406 & 126 & 65.4 & 1.90 & 3.26 & .42 & .00181 & .00152 & 5.1 & .027 \\
\hline 948 & 214 & 73.1 & 2.87 & 4.46 & .46 & .00192 & .00150 & 15.6 & .026 \\
\hline 994 & 226 & 74.9 & 2.96 & 4.43 & .45 & .00200 & .00157 & 17.7 & .028 \\
\hline$\ddagger 1,890$ & 328 & 85.2 & 4.10 & 5.80 & .48 & .00234 & .00145 & 27.8 & .026 \\
\hline
\end{tabular}

* The data used for this n-value calculation were collected during the growing season.

$\$$ For this $n$-value calculation, a low overbank area on the left bank, which accounts for less than 7.5 percent of the total flow area, was divided from the rest of the cross section and assigned a roughness coefficient of 0.034 . Failure to subdivide the cross sections in this manner would have produced an erroneously low $\mathbf{n}$ value. 


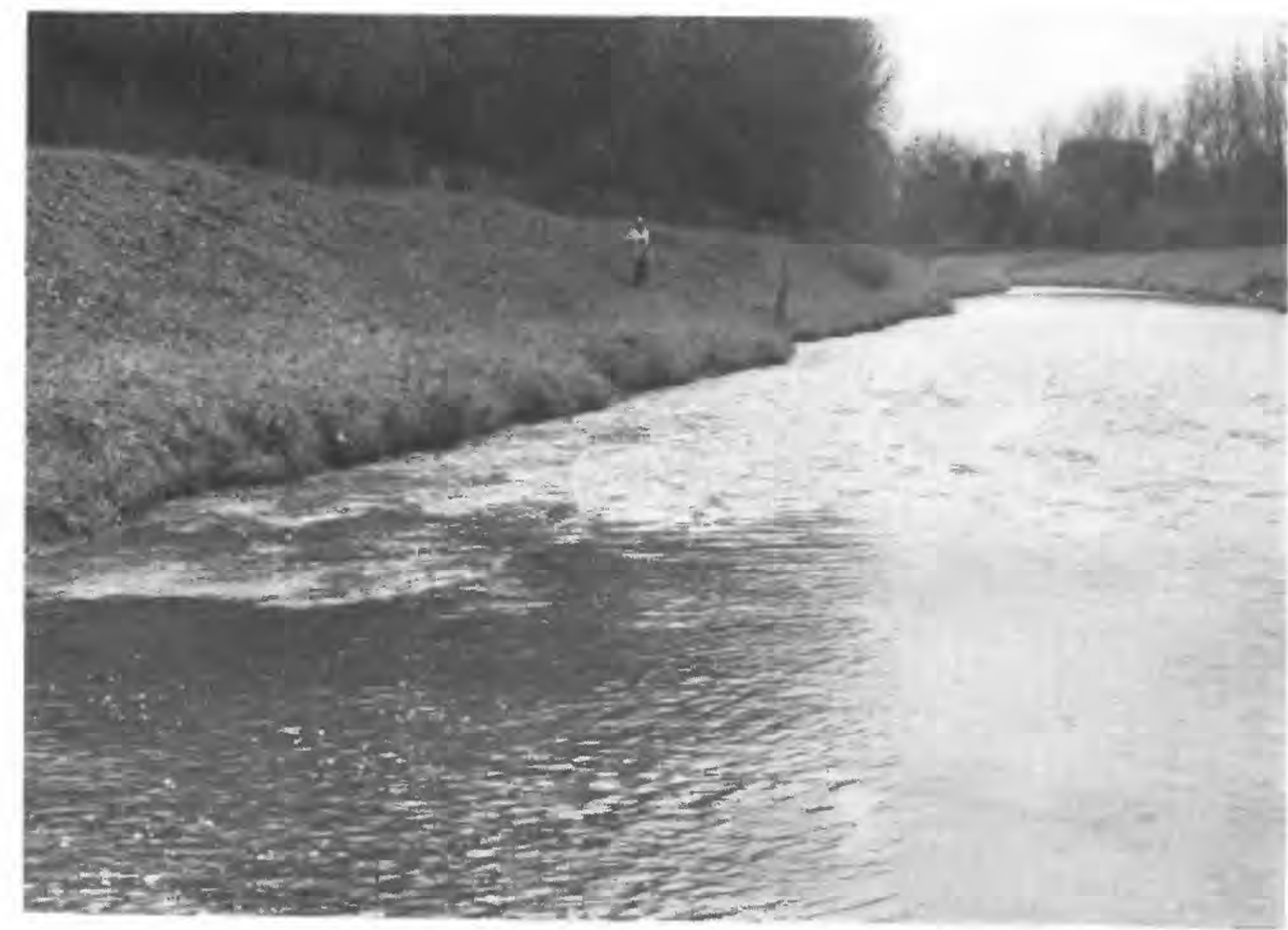

View from cross section 1, facing downstream toward left bank. Hydrographer is at section 2 standing at approximate water-surface elevation of maximum recorded discharge.

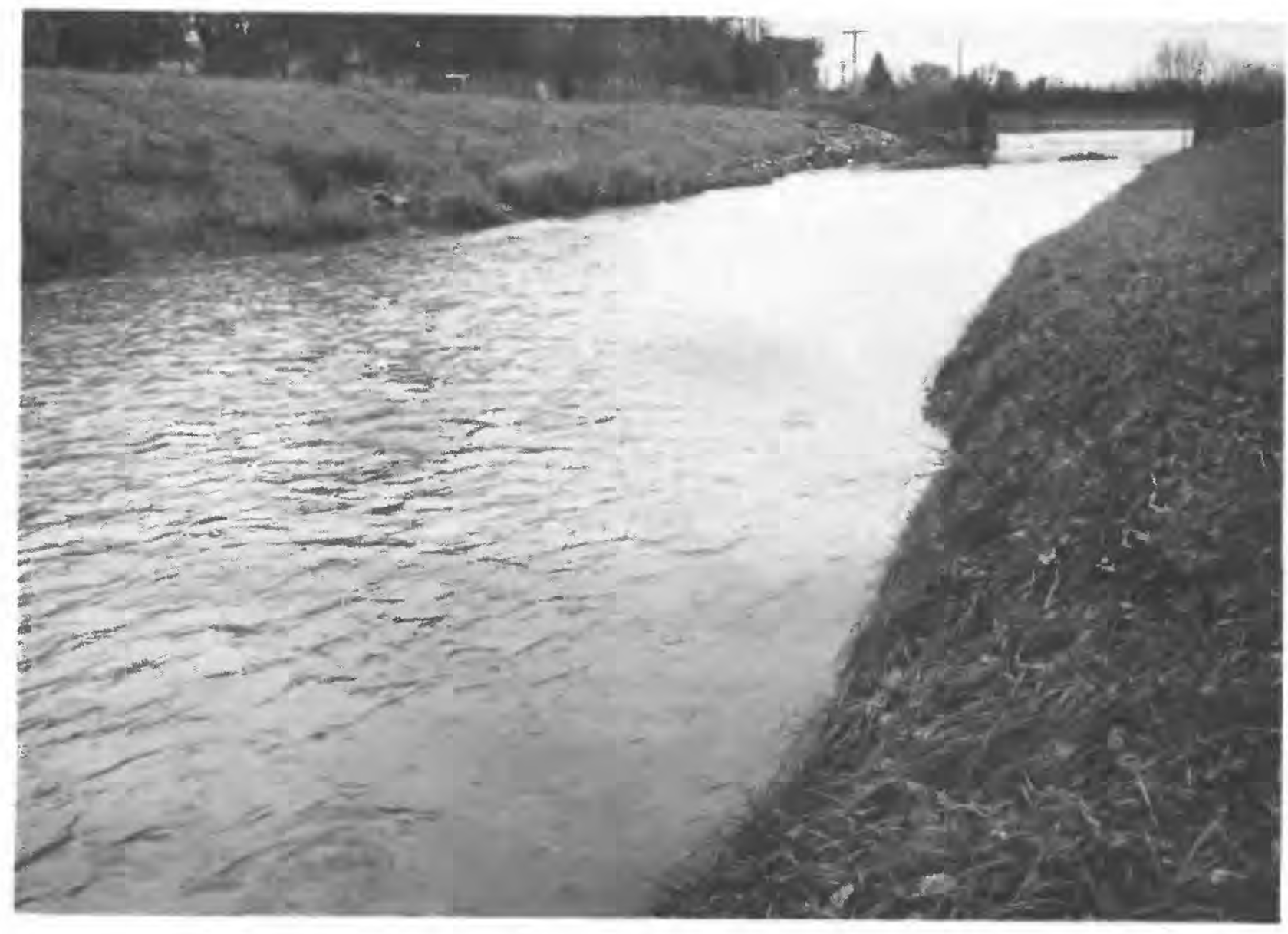

View from cross section 2, facing upstream toward right bank. Hydrographer is at section 1.

Figure A2-8. Onondaga Creek at Dorwin Avenue, Syracuse, N.Y. A. Photographs duning late fall. 


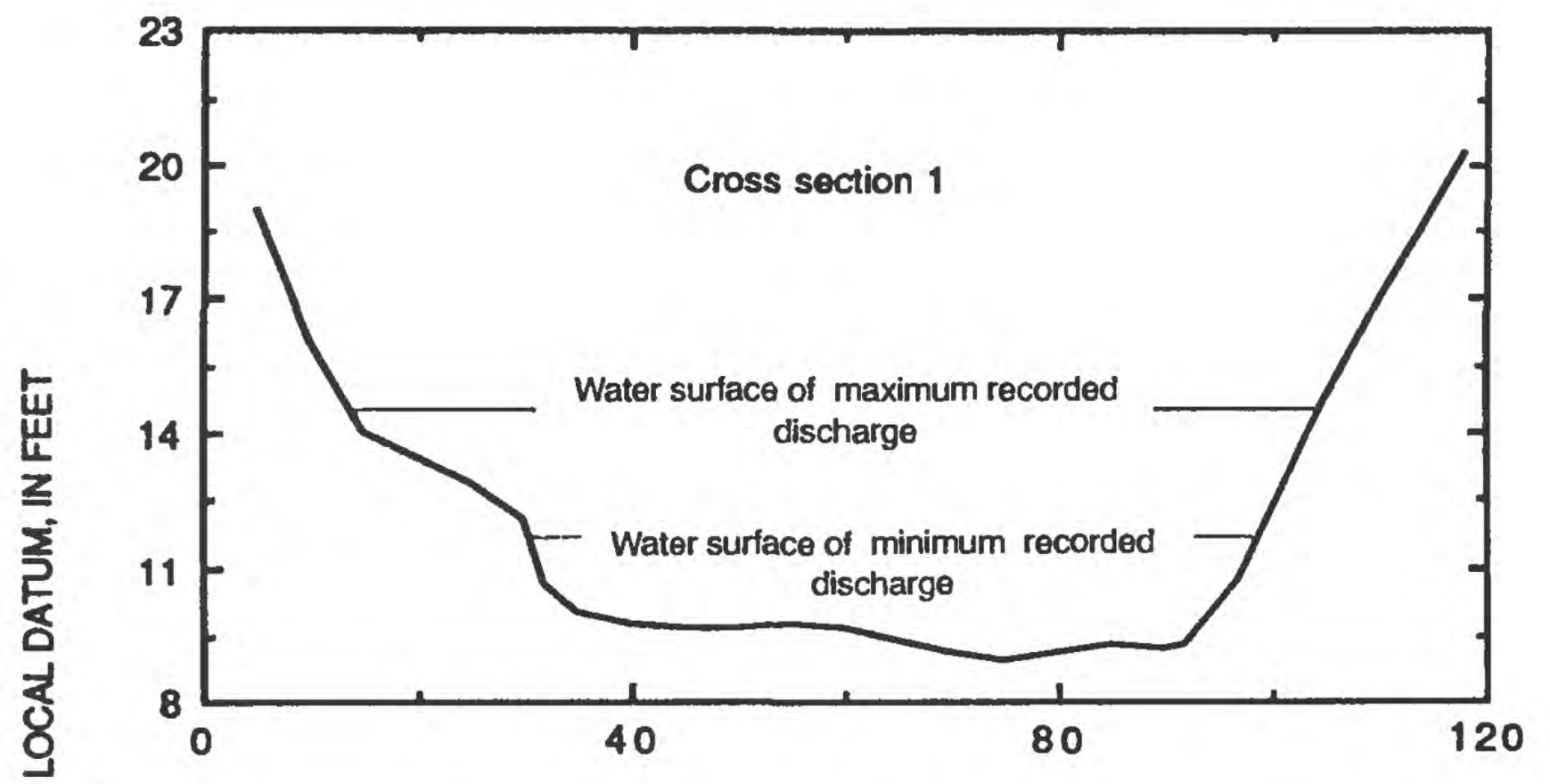

Figure A2-8. Onondaga Creek at Dorwin Avenue, Syracuse, N.Y. (continued). B. Cross sections. (Locations are shown in plan view on p. 75.) 
PLAN VIEW (not to scale)

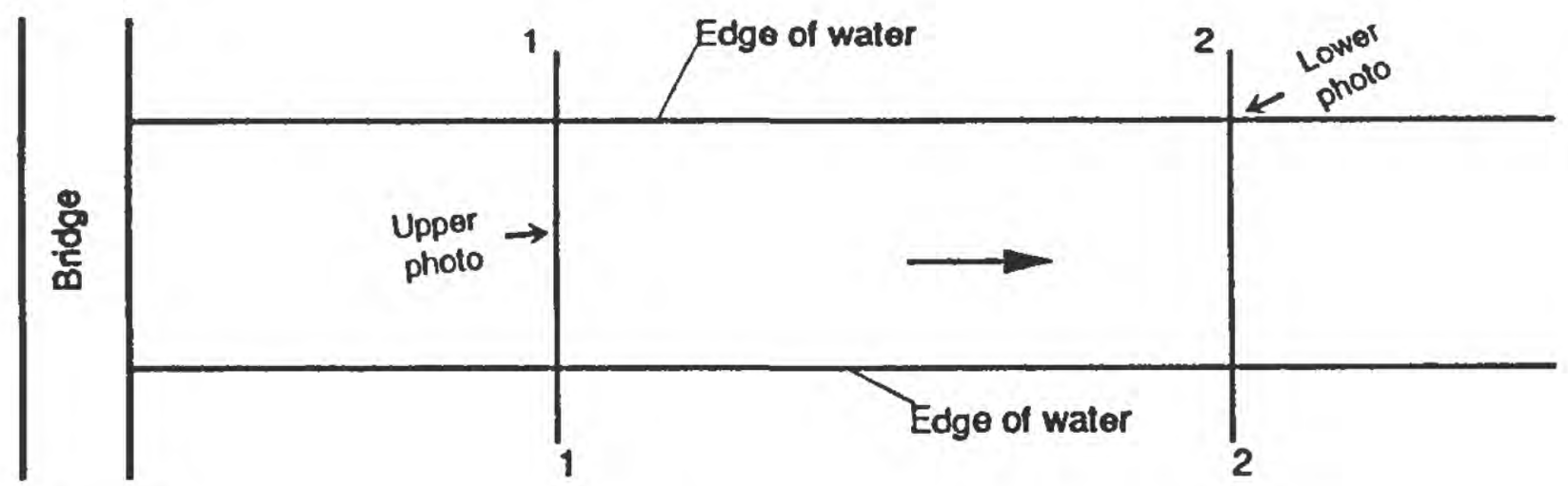

EXPLANATIN
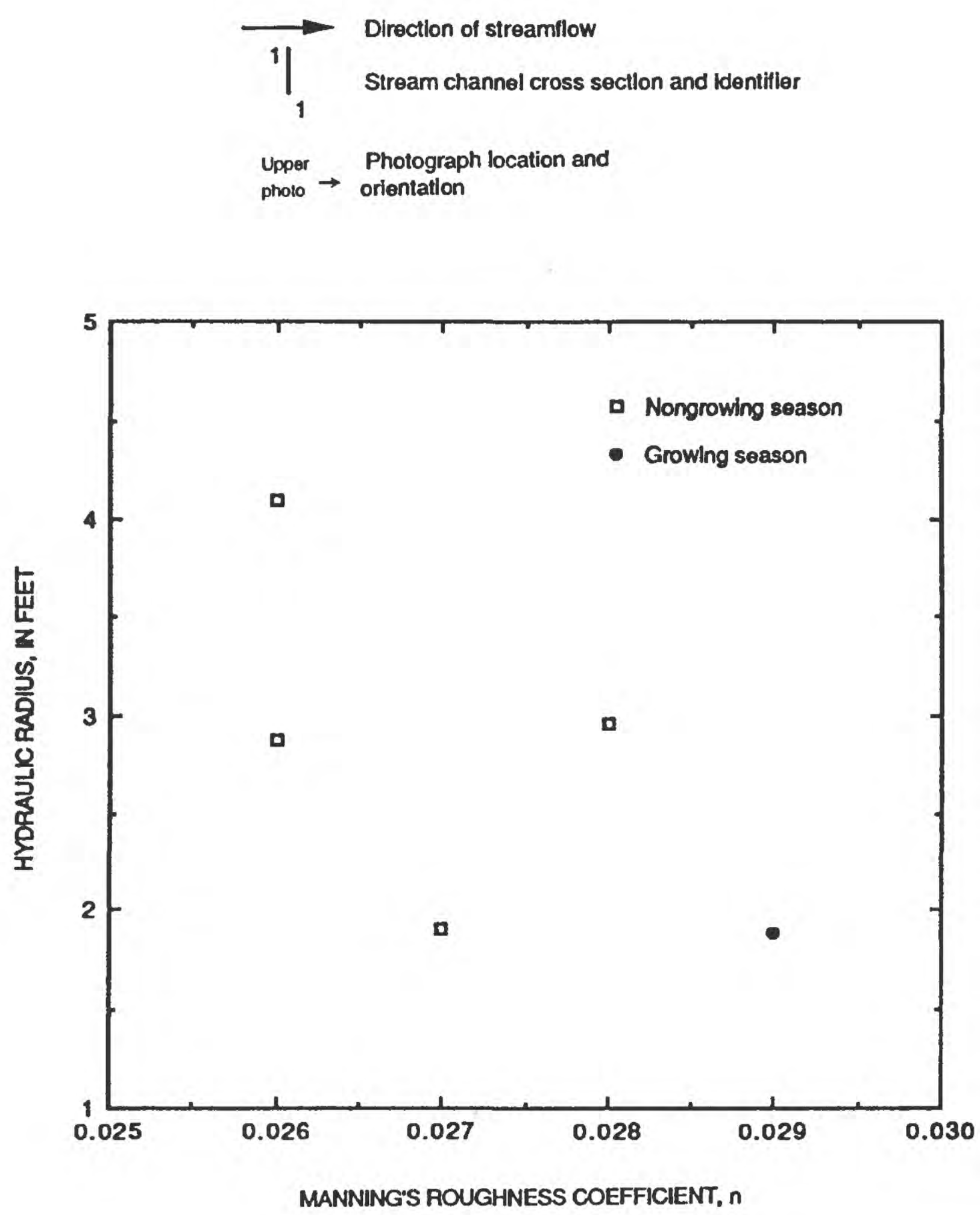

Figure A2-8. Onondaga Creek at Dorwin Avenue, Syracuse, N.Y. (continued). C. Plan view and relation between hydraulic radius and Manning's roughness coefficient during growing and nongrowing seasons. 


\section{SITE 9. TIOUGHNIOGA RIVER AT ITASKA, N.Y.}

Table A2-9. Station description and hydraulic data

Location.--Latitude $42^{\circ} 17^{\prime} 53^{\prime \prime}$, longitude $75^{\circ} 54^{\prime} 33^{\prime \prime}$, Broome County, on right bank at Itaska, $3.8 \mathrm{mi}$ downstream from Otselic River and village of Whitney Point, and 6 mi upstream from mouth. A 3-section, 1,030-ft-long reach; section 1 is at the gage.

USGS station-identification number.--01511500.

Drainage area.--730 $\mathrm{mi}^{2}$.

Bed material.--Cobbles. Intermediate diameter $\mathrm{d}_{50}=0.29 \mathrm{ft}$ and $\mathrm{d}_{84}=0.50 \mathrm{ft}$. Minimum diameter $\mathrm{d}_{50}=0.09 \mathrm{ft}$.

Bank description.--Both banks have grass and brush; trees 1 to $2 \mathrm{ft}$ in diameter are near top of bank.

Low-overflow area on right bank at cross section 2 is vegetated with large trees spaced about $20 \mathrm{ft}$ apart and summer growth of grass and ferns. Vegetation indices: 1, 1.5 (low-overflow area not included).

Remarks.--Floodflows are partly regulated by Whitney Point Lake. The percentages of wetted perimeter that are vegetated are high in comparison to other sites because the vegetated overflow area on the right bank at cross section 2 is included in these values. The velocity-head coefficients computed from discharge measurements made at this site range from 1.30 to 1.47 for discharges between 5,000 and $11,000 \mathrm{ft}^{3} / \mathrm{s}$.

\section{Hydraulic Data}

$\left[\mathrm{ft}=\mathrm{feet} ; \mathrm{ft}^{2}=\right.$ square feet; $\mathrm{ft} / \mathrm{s}=$ feet per second; $\mathrm{ft}^{3} / \mathrm{s}=$ cubic feet per second. $]$

\begin{tabular}{|c|c|c|c|c|c|c|c|c|c|}
\hline \multirow[b]{2}{*}{$\begin{array}{c}\text { Discharge } \neq \\
\left(\mathrm{ft}^{3} / \mathrm{s}\right)\end{array}$} & \multicolumn{5}{|c|}{ Average values for reach } & \multirow[b]{2}{*}{$\begin{array}{c}\text { Water- } \\
\text { surface } \\
\text { slope }\end{array}$} & \multirow[b]{2}{*}{$\begin{array}{c}\text { Energy } \\
\text { gradient }\end{array}$} & \multirow[b]{2}{*}{$\begin{array}{c}\text { Percent } \\
\text { wetted } \\
\text { perimeter } \\
\text { vegetated }\end{array}$} & \multirow[b]{2}{*}{$\begin{array}{c}\text { Manning's } \\
n\end{array}$} \\
\hline & $\begin{array}{l}\text { Area } \\
\left(\mathrm{ft}^{2}\right)\end{array}$ & $\begin{array}{l}\text { Width } \\
\text { (ft) }\end{array}$ & $\begin{array}{c}\text { Hydraulic } \\
\text { radius } \\
(\mathrm{ft})\end{array}$ & $\begin{array}{c}\text { Velocity } \\
(\mathrm{ft} / \mathrm{s})\end{array}$ & $\begin{array}{l}\text { Froude } \\
\text { number }\end{array}$ & & & & \\
\hline$* \S 503$ & 370 & 211 & 1.65 & 1.40 & 0.20 & 0.00050 & 0.00050 & 0 & 0.030 \\
\hline$\S 4,560$ & 1,120 & 265 & 4.23 & 4.07 & .35 & .00111 & .00108 & 17.6 & .031 \\
\hline$\S 5,420$ & 1,230 & 269 & 4.57 & 4.41 & .36 & .00120 & .00115 & 18.5 & .031 \\
\hline 5,640 & 1,280 & 270 & 4.74 & 4.40 & .36 & .00113 & .00110 & 19.1 & .031 \\
\hline$\S 6,060$ & 1,330 & 272 & 4.90 & 4.55 & .36 & .00119 & .00114 & 19.4 & .032 \\
\hline 6,460 & 1,390 & 273 & 5.07 & 4.66 & .36 & .00118 & .00113 & 20.0 & .032 \\
\hline 6,610 & 1,380 & 274 & 5.03 & 4.81 & .38 & .00133 & .00126 & 20.0 & .032 \\
\hline$\$ 7,570$ & 1,520 & 277 & 5.45 & 5.00 & .38 & .00120 & .00115 & 21.1 & .031 \\
\hline$\ddagger 9,940$ & 1,780 & 284 & 6.24 & 5.59 & .39 & .00132 & .00122 & 24.6 & .032 \\
\hline$\$ 10,100$ & 1,810 & 285 & 6.33 & 5.58 & .39 & .00122 & .00113 & 26.4 & .031 \\
\hline$\S \div 10,800$ & 1,870 & 286 & 6.50 & 5.79 & .40 & .00132 & .00122 & 29.7 & .031 \\
\hline$\$ 10,900$ & 1,880 & 286 & 6.53 & 5.81 & .40 & .00133 & .00122 & 29.7 & .032 \\
\hline$\S \ddagger 11,400$ & 1,930 & 287 & 6.66 & 5.91 & .40 & .00136 & .00125 & 32.5 & .032 \\
\hline
\end{tabular}

* The data used for this n-value calculation were collected during the growing season.

$\S$ The $\mathrm{n}$ values computed for each subreach differ by 0.004 to 0.008 .

$¥$ The right-bank overflow area at cross section 3 is treated as ineffective-flow area for this $\mathbf{n}$-value calculation.

The data reflect this modification to the cross section. 


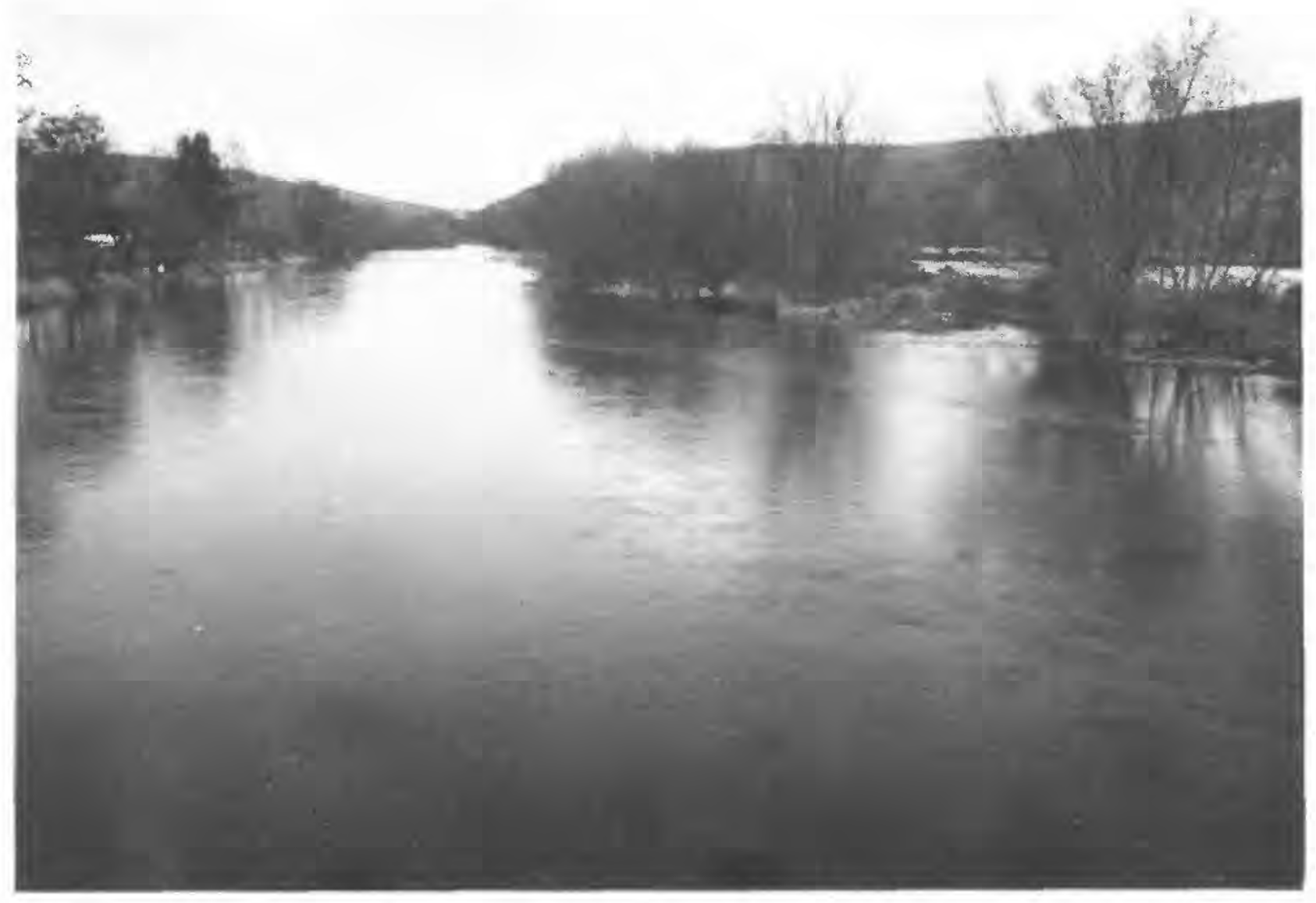

View from cross section 1, facing downstream toward right bank. Hydrographer is at section 2 holding cross-section-identification card (white speck at edge of water near left edge of photo).

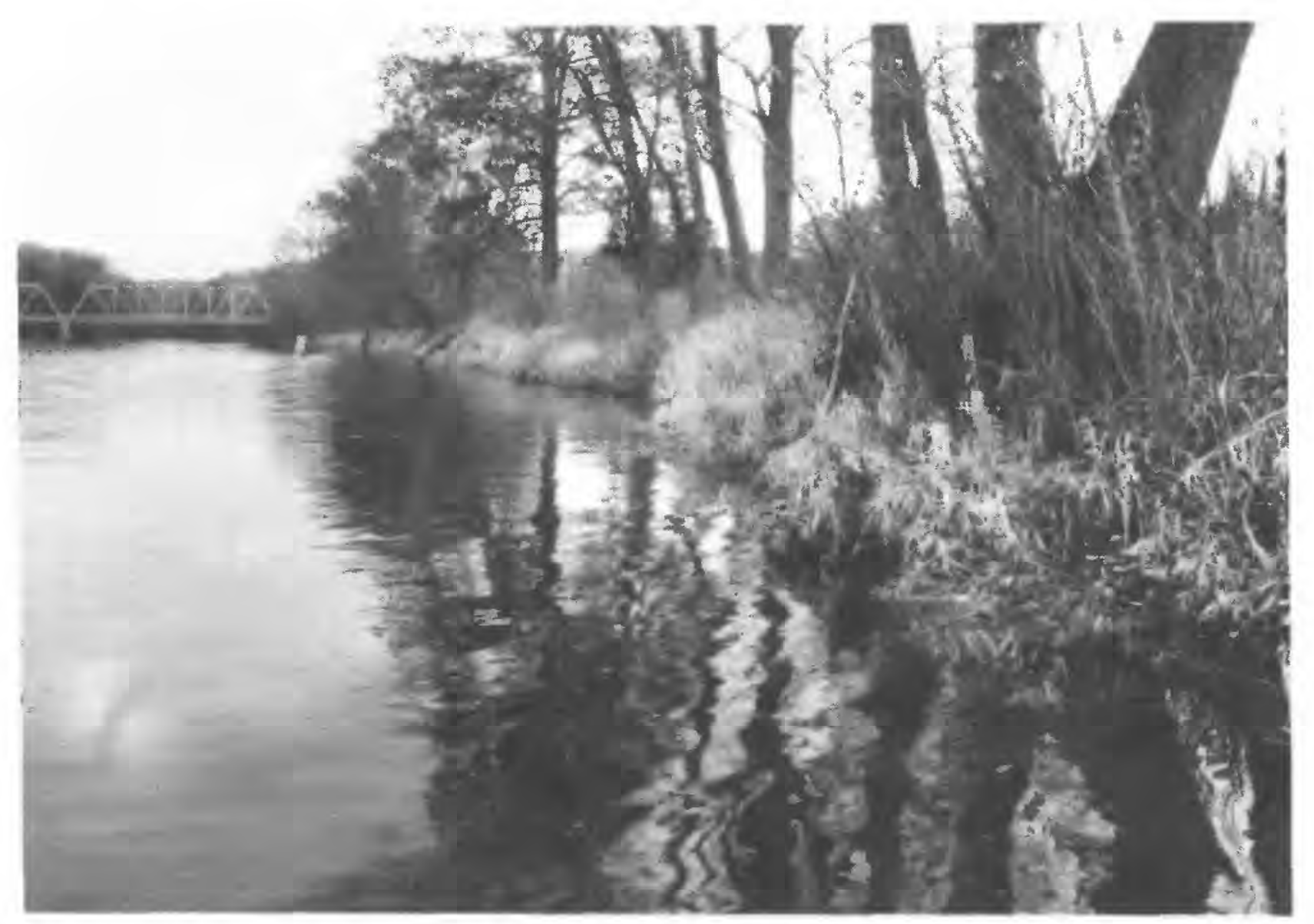

View from cross section 3, facing upstream along left bank.

Hydrographer is at section 2.

Figure A2-9. Tioughnioga River at Itaska, N.Y. A. Photographs during late fall. 


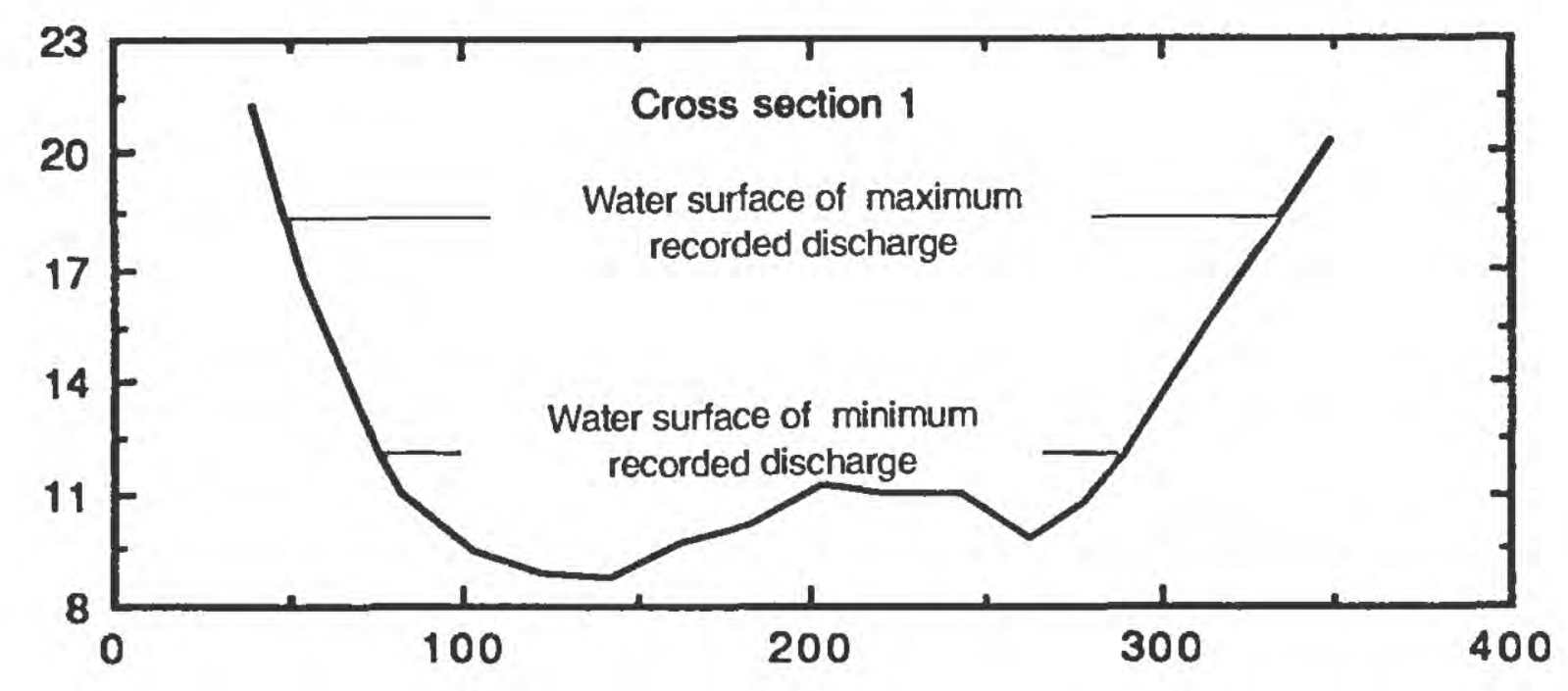

乩
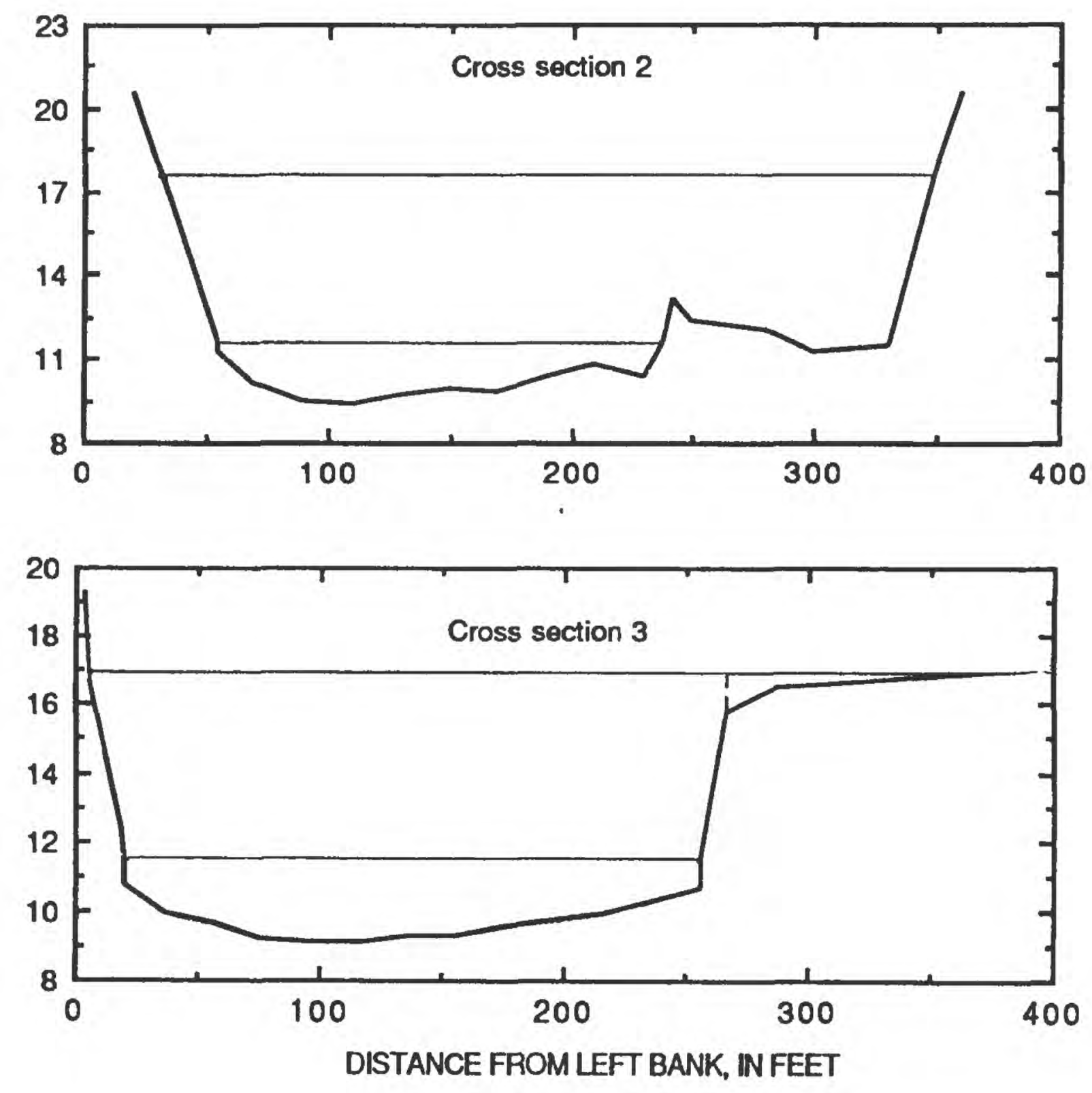

Figure A2-9. Tioughnioga River at Itaska, N.Y. (continued). view on p. 79.)

B. Cross sections. (Locations are shown in plan 
PLAN VIEW (not to scale)

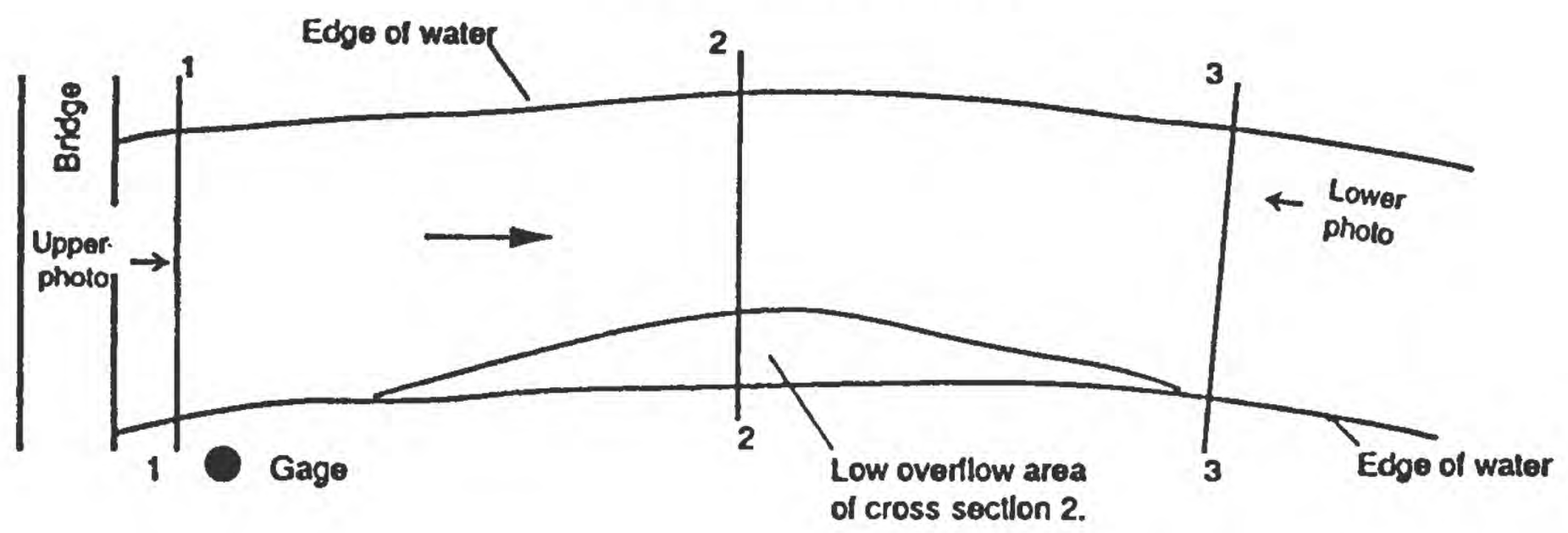

\section{EXPLANATION}
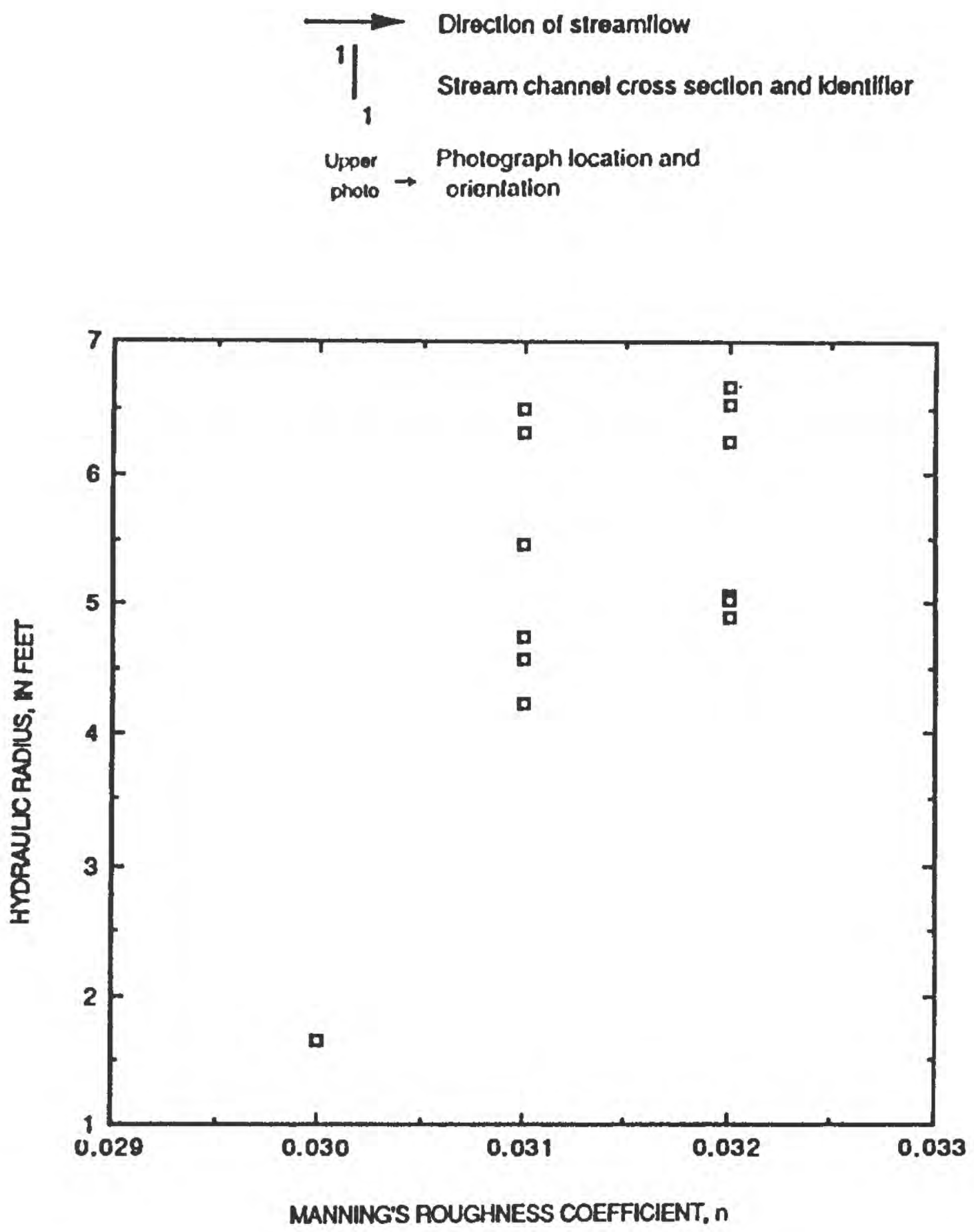

Figure A2-9. Tioughnioga River at ltaska, N.Y. (continued).

C. Plan view and relation between hydraulic radius and Manning's roughness coefficient . 


\section{SITE 10. KAYADEROSSERAS CREEK NEAR WEST MILTON, N.Y.}

Table A2-10. Station description and hydraulic data

Location.--Latitude $43^{\circ} 02^{\prime} 18^{\prime \prime}$, longitude $73^{\circ} 54^{\prime} 35^{\prime \prime}$, Saratoga County, on left bank $600 \mathrm{ft}$ downstream from Glowegee Creek, $1.0 \mathrm{mi}$ east of West Milton, and $3.5 \mathrm{mi}$ northwest of Ballston Spa. A 2section, 203-ft-long reach; section 1 is at the gage.

USGS station-identification number.--01330500.

Drainage area.--90.0 $\mathrm{mi}^{2}$.

Bed material.--Rounded cobbles and small boulders. Intermediate diameter $\mathrm{d}_{50}=0.35 \mathrm{ft}$ and $\mathrm{d}_{84}=$ $0.83 \mathrm{ft}$. Minimum diameter $\mathrm{d}_{50}=0.20 \mathrm{ft}$.

Bank description.--Left bank is steep with some brush and 0.5- to 1.0-ft-diameter trees spaced 15 to 20 $\mathrm{ft}$ apart. Right bank is scalloped with exposed tree roots. Top of right bank is vegetated with 2-ftdiameter trees at water's edge and smaller trees beyond. Soft-stemmed plant growth is dense across the right-bank overflow area during the growing season. Vegetation indices: 2, 3.

Remarks.--The high percentage of wetted perimeter that is vegetated for the flow of $1,700 \mathrm{ft}^{3} / \mathrm{s}$ reflects the additional vegetated overflow area on the right bank. The $\mathrm{n}$ values computed for this site are affected by streambank irregularities and by channel-size and -shape variations.

\section{Hydraulic Data}

$\left[\mathrm{ft}=\right.$ feet; $\mathrm{ft}^{2}=$ square feet; $\mathrm{ft} / \mathrm{s}=$ feet per second; $\mathrm{ft}^{3} / \mathrm{s}=$ cubic feet per second. $]$

\begin{tabular}{|c|c|c|c|c|c|c|c|c|c|}
\hline \multirow[b]{2}{*}{$\begin{array}{c}\text { Discharget } \\
\left(\mathrm{ft}^{3} / \mathrm{s}\right)\end{array}$} & \multicolumn{5}{|c|}{ Average values for reach } & \multirow[b]{2}{*}{$\begin{array}{l}\text { Water- } \\
\text { surface } \\
\text { slope }\end{array}$} & \multirow[b]{2}{*}{$\begin{array}{l}\text { Energy } \\
\text { gradient }\end{array}$} & \multirow[b]{2}{*}{$\begin{array}{c}\text { Percent } \\
\text { wetted } \\
\text { perimeter } \\
\text { vegetated }\end{array}$} & \multirow[b]{2}{*}{$\underset{n}{\text { Manning's }}$} \\
\hline & $\begin{array}{l}\text { Area } \\
\left(\mathrm{ft}^{2}\right)\end{array}$ & $\begin{array}{l}\text { Width } \\
\text { (ft) }\end{array}$ & $\begin{array}{l}\text { Hydraulic } \\
\text { radius } \\
\text { (ft) }\end{array}$ & $\begin{array}{l}\text { Velocity } \\
(\mathrm{ft} / \mathrm{s})\end{array}$ & $\begin{array}{l}\text { Froude } \\
\text { number }\end{array}$ & & & & \\
\hline *877 & 293 & 78.7 & 3.57 & 3.13 & 0.32 & 0.00379 & 0.00317 & 12.6 & 0.063 \\
\hline 952 & 306 & 80.1 & 3.65 & 3.26 & .33 & .00404 & .00336 & 14.5 & .064 \\
\hline$\$ 1,010$ & 318 & 81.4 & 3.74 & 3.30 & .32 & .00384 & .00318 & 15.8 & .063 \\
\hline$* \ddagger 1,050$ & 325 & 82.2 & 3.80 & 3.36 & .33 & .00379 & .00313 & 16.6 & .062 \\
\hline$* \ddagger 1,060$ & 335 & 88.0 & 3.70 & 3.26 & .31 & .00296 & .00242 & 21.9 & .056 \\
\hline$\ddagger 1,070$ & 334 & 87.7 & 3.69 & 3.32 & .32 & .00330 & .00271 & 21.6 & .059 \\
\hline$\$ 1,110$ & 338 & 88.0 & 4.01 & 3.36 & .32 & .00365 & .00340 & 22.0 & .061 \\
\hline$\S 1,700$ & 446 & 99.0 & 4.62 & 3.90 & .33 & .00369 & .00315 & 31.1 & .057 \\
\hline
\end{tabular}

* The data used for this n-value calculation were collected during the growing season.

$\$$ The right-bank overflow area at cross section 2 is treated as ineffective-flow area for this n-value calculation. $\S$ For this n-value calculation, the overbank area at cross section 2, which accounts for 1.4 to 7.8 percent of the total flow area, was divided from the rest of the cross section and assigned a roughness coefficient of 0.080 . 


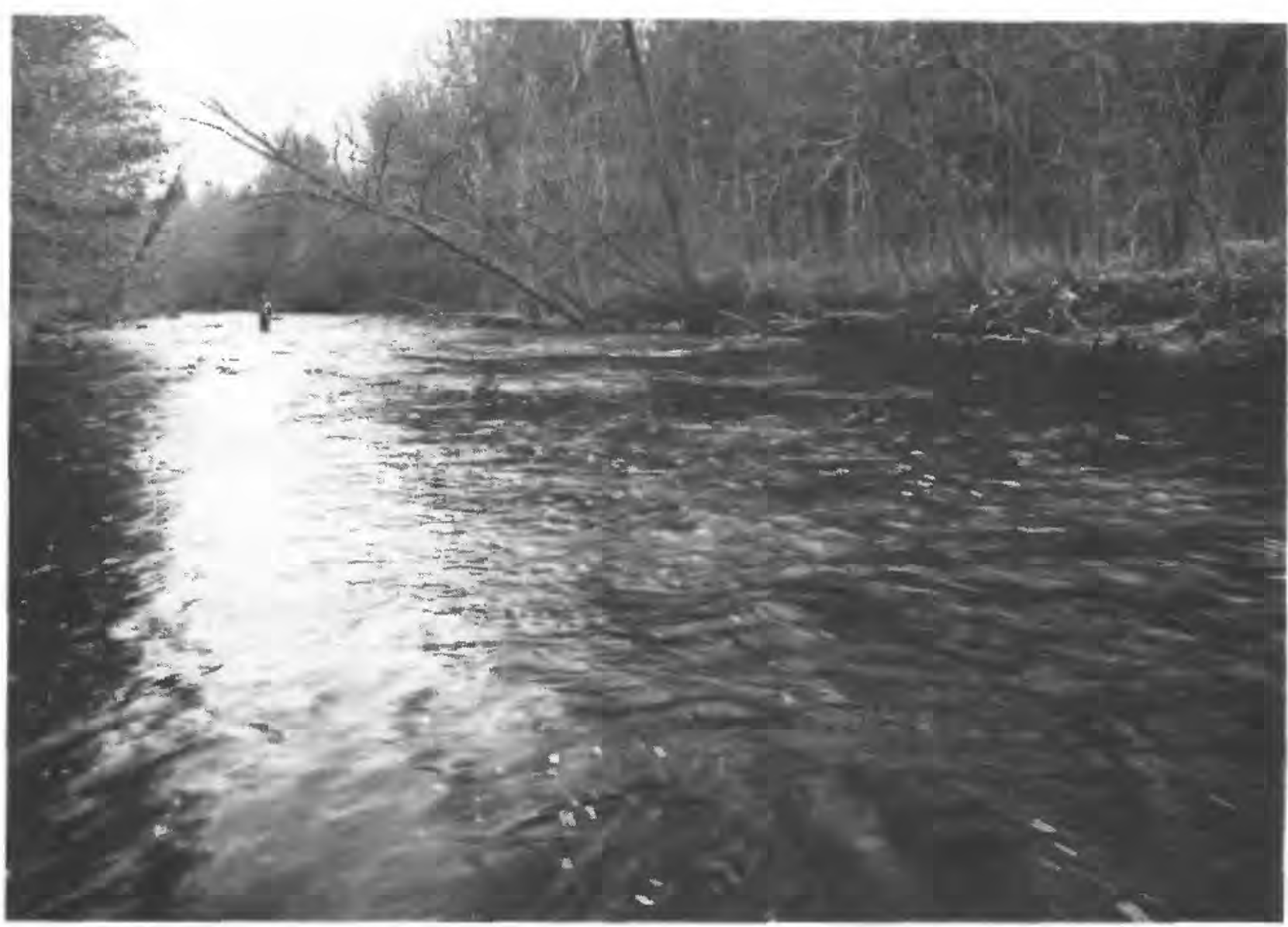

View from cross section 1, facing downstream toward right bark. Hydrographer is at section 2.

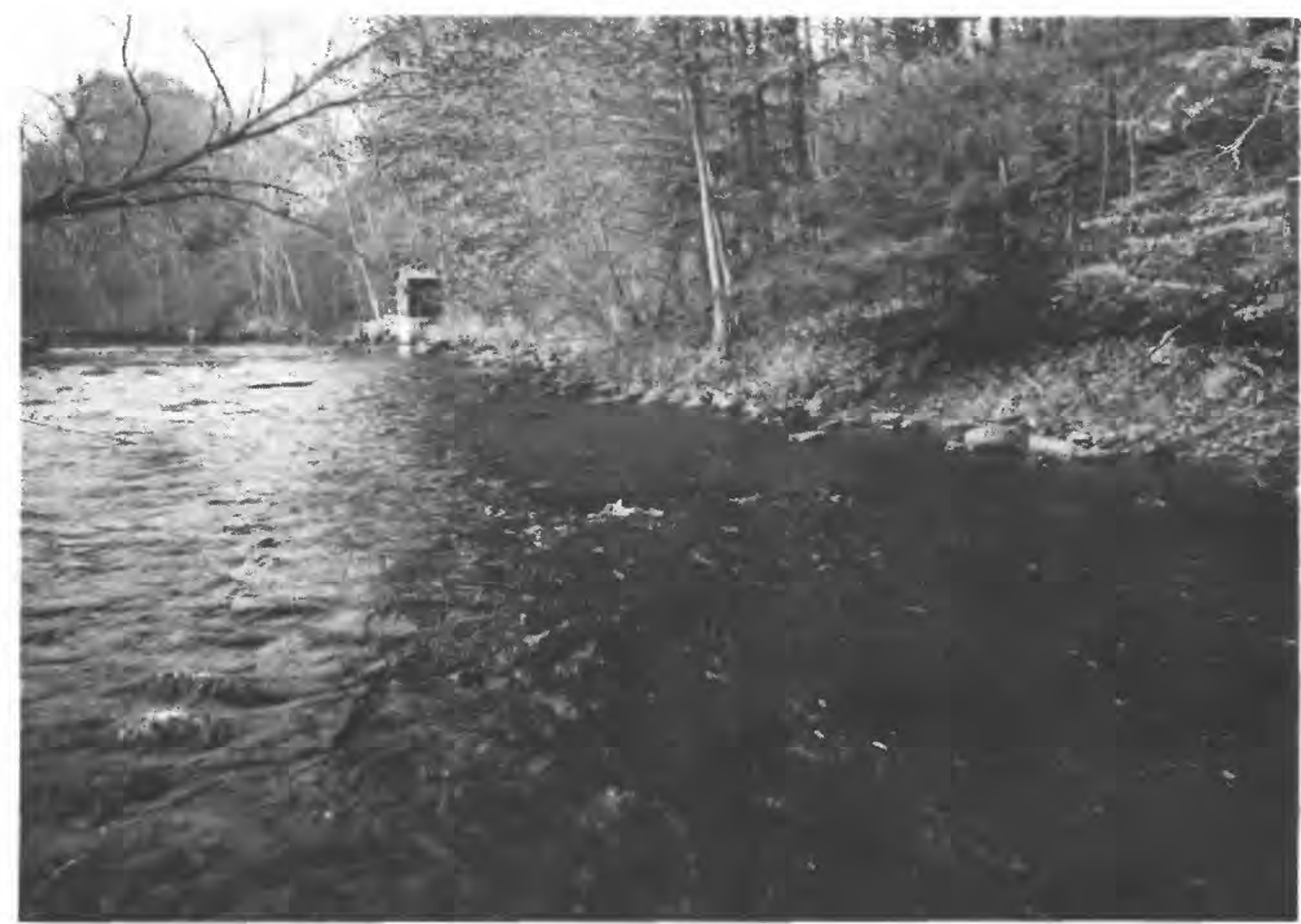

View from below cross section 2, facing upstream toward left bank. Streamflow-gaging-station shelter is at section 1.

Figure A2-10. Kayaderosseras Creek near West Milton, N.Y. A. Photographs during late fall. 


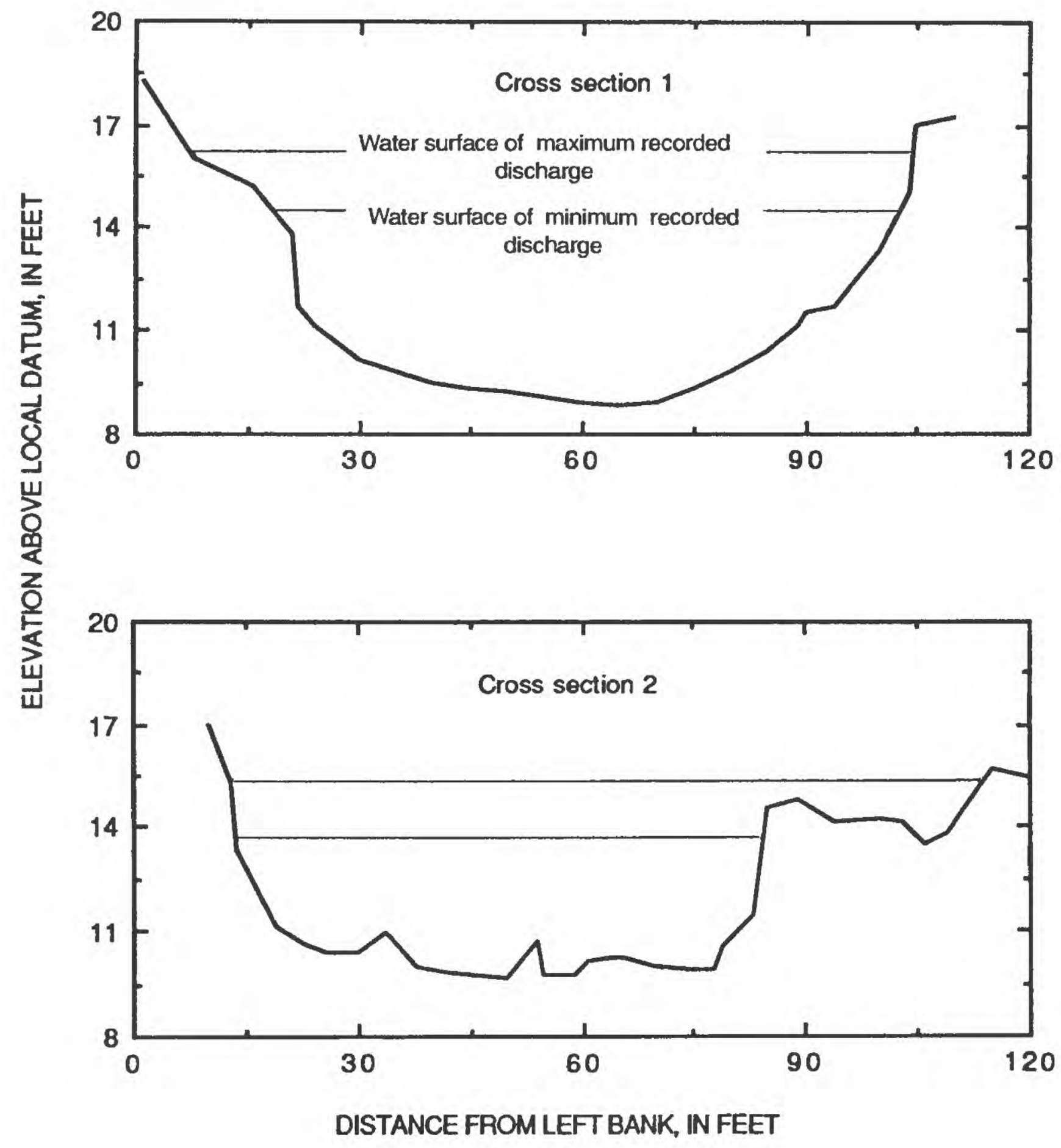

Flgure A2-10. Kayderosseras Creek near West Milton, N.Y. (continued). B. Cross sections. (Locations are shown in plan view on p. 83.) 
PLAN VIEW (not to scale)

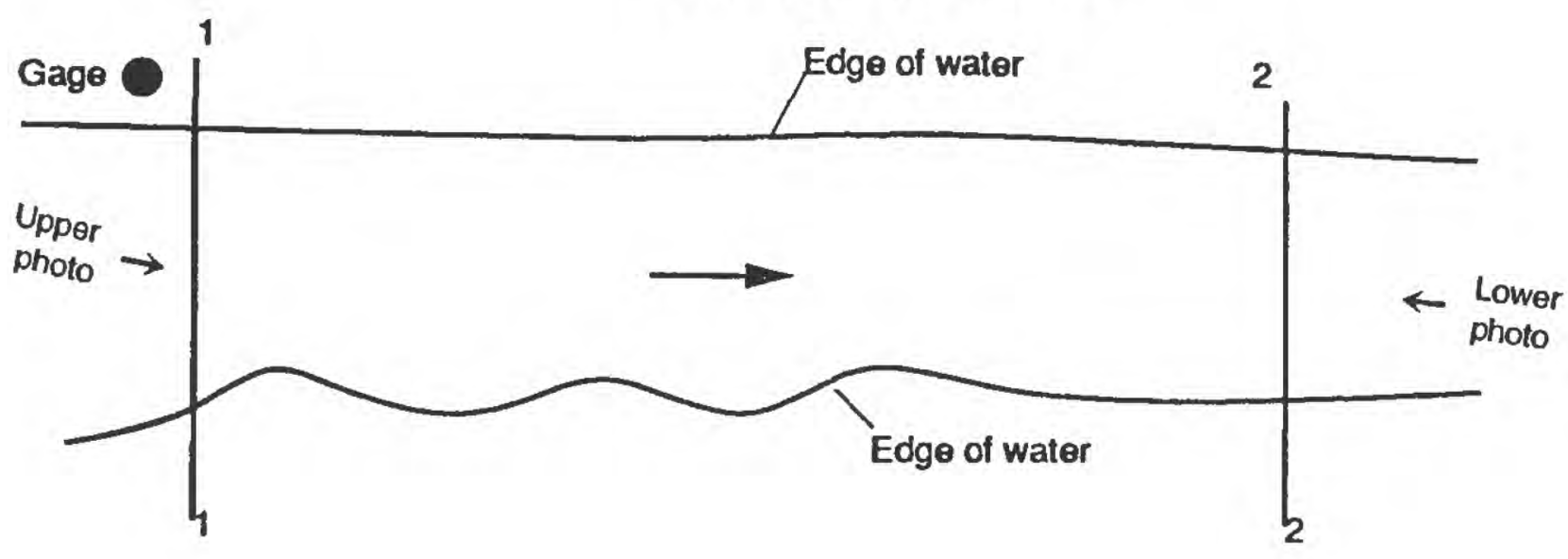

EXPLANATION
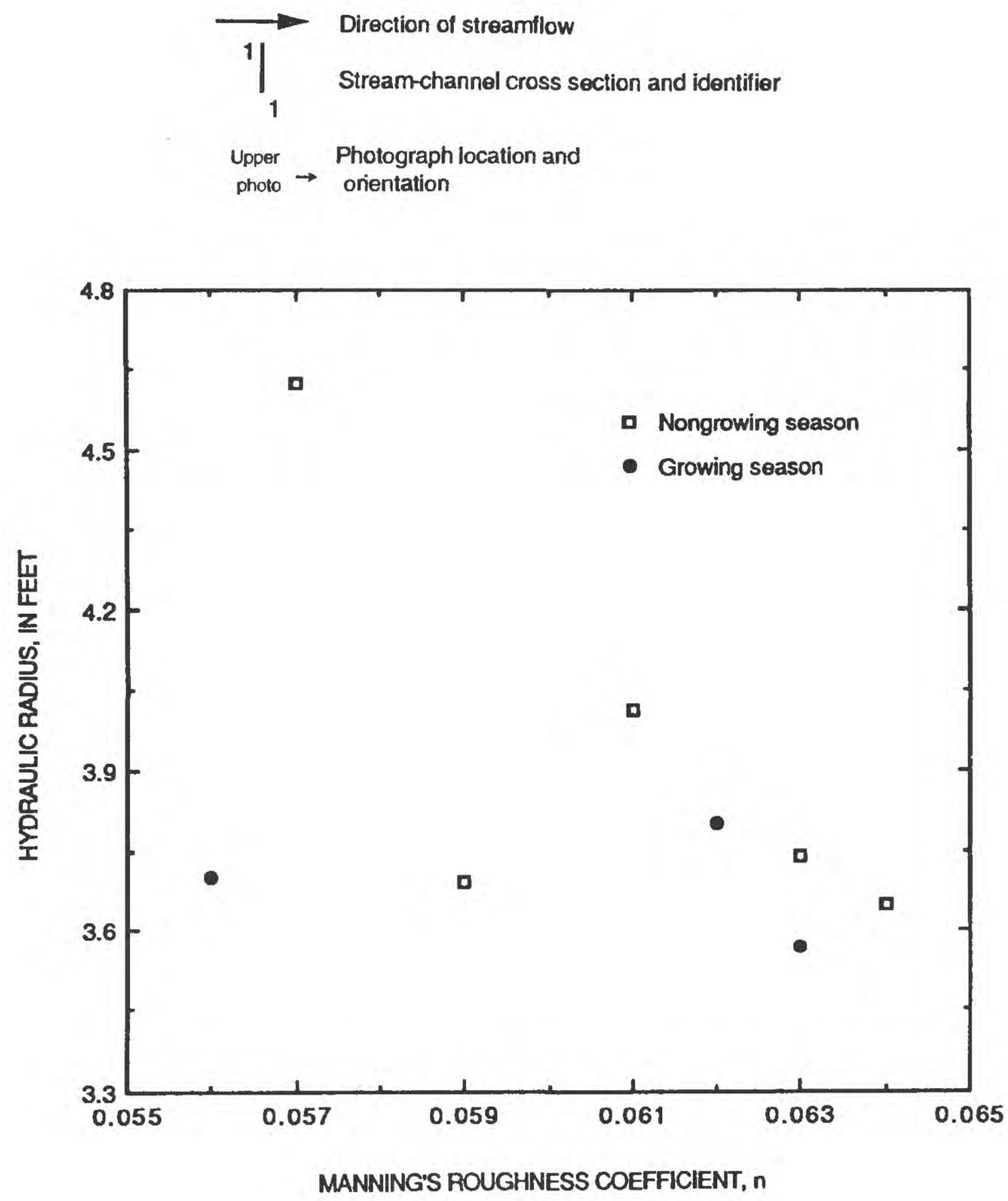

Figure A2-10. Kayderosseras Creek near West Milton, N.Y. (continued). C. Plan view and relation between hydraulic radius and Manning's roughness coefficient during growing and nongrowing seasons. 


\section{SITE 11. INDIAN RIVER NEAR INDIAN LAKE, N.Y.}

Table A2-11. Station description and hydraulic data

Location.--Latitude $43^{\circ} 45^{\prime} 30^{\prime \prime}$, longitude $74^{\circ} 16^{\prime} 05^{\prime \prime}$, Hamilton County, on right bank 0.8 mi downstream from Indian Lake Dam, $1.0 \mathrm{mi}$ upstream from Big Brook, and $2.0 \mathrm{mi}$ south of village of Indian Lake. A 2-section, 101-ft-long reach; section 1 is about $200 \mathrm{ft}$ downstream from gage.

USGS station identification number.--01315000.

Drainage area.--132 $\mathrm{mi}^{2}$.

Bed material.--Boulders. Intermediate diameter $\mathrm{d}_{50}=1.20 \mathrm{ft}$ and $\mathrm{d}_{84}=1.80 \mathrm{ft}$. Minimum diameter $\mathrm{d}_{50}=0.50 \mathrm{ft}$.

Bank description.--Both banks lined with boulders 2 to $3 \mathrm{ft}$ in diameter. Banks are vegetated with trees mostly 1 to $2 \mathrm{ft}$ in diameter and spaced 10 to $15 \mathrm{ft}$ apart. No brush or shrubs are growing among the trees. Some fallen trees at water's edge are aligned with flow. Vegetation indices: 2, 2.

Remarks.--Flow is regulated by Indian Lake.

\section{Hydraulic Data}

$\left[\mathrm{ft}=\mathrm{fcet} ; \mathrm{ft}^{2}=\right.$ square feet; $\mathrm{ft} / \mathrm{s}=$ feet per second; $\mathrm{ft}^{3} / \mathrm{s}=$ cubic feet per second. $]$

\begin{tabular}{|c|c|c|c|c|c|c|c|c|c|}
\hline \multirow[b]{2}{*}{$\begin{array}{c}\text { Discharge } \\
\left(\mathrm{ft}^{3} / \mathrm{s}\right)\end{array}$} & \multicolumn{5}{|c|}{ Average values for reach } & \multirow[b]{2}{*}{$\begin{array}{c}\text { Water- } \\
\text { surface } \\
\text { slope }\end{array}$} & \multirow[b]{2}{*}{$\begin{array}{l}\text { Energy } \\
\text { gradient }\end{array}$} & \multirow[b]{2}{*}{$\begin{array}{c}\text { Percent } \\
\text { wetted } \\
\text { perimeter } \\
\text { vegetated }\end{array}$} & \multirow[b]{2}{*}{$\begin{array}{c}\text { Manning's } \\
\text { n }\end{array}$} \\
\hline & $\begin{array}{l}\text { Area } \\
\left(\mathrm{ft}^{2}\right)\end{array}$ & $\begin{array}{l}\text { Width } \\
\text { (ft) }\end{array}$ & $\begin{array}{l}\text { Hydraulic } \\
\text { radius } \\
\text { (ft) }\end{array}$ & $\begin{array}{c}\text { Velocity } \\
(\mathrm{ft} / \mathrm{s})\end{array}$ & $\begin{array}{l}\text { Froude } \\
\text { number }\end{array}$ & & & & \\
\hline 98 & 64.8 & 45.6 & 1.39 & 1.51 & 0.22 & 0.01109 & 0.01106 & 0 & 0.129 \\
\hline 129 & 65.6 & 45.8 & 1.40 & 1.96 & .29 & .01050 & .01049 & 0 & .097 \\
\hline 194 & 76.2 & 47.6 & 1.56 & 2.55 & .35 & .01079 & .01071 & 0 & .081 \\
\hline 212 & 75.3 & 47.4 & 1.55 & 2.82 & .39 & .01119 & .01103 & 0 & .074 \\
\hline 296 & 92.2 & 54.0 & 1.67 & 3.22 & .43 & .01139 & .01116 & 0 & .069 \\
\hline 331 & 96.0 & 54.5 & 1.72 & 3.46 & .46 & .01198 & .01161 & 0 & .066 \\
\hline 362 & 100 & 55.2 & 1.78 & 3.62 & .48 & .01277 & .01221 & 0 & .066 \\
\hline 452 & 114 & 57.6 & 1.95 & 3.95 & .50 & .01248 & .01199 & 0 & .064 \\
\hline 641 & 139 & 60.2 & 2.26 & 4.63 & .54 & .01376 & .01293 & 0 & .063 \\
\hline 718 & 148 & 61.0 & 2.38 & 4.86 & .55 & .01386 & .01300 & 0 & .062 \\
\hline 794 & 157 & 61.7 & 2.48 & 5.08 & .56 & .01406 & .01312 & 0 & .061 \\
\hline
\end{tabular}




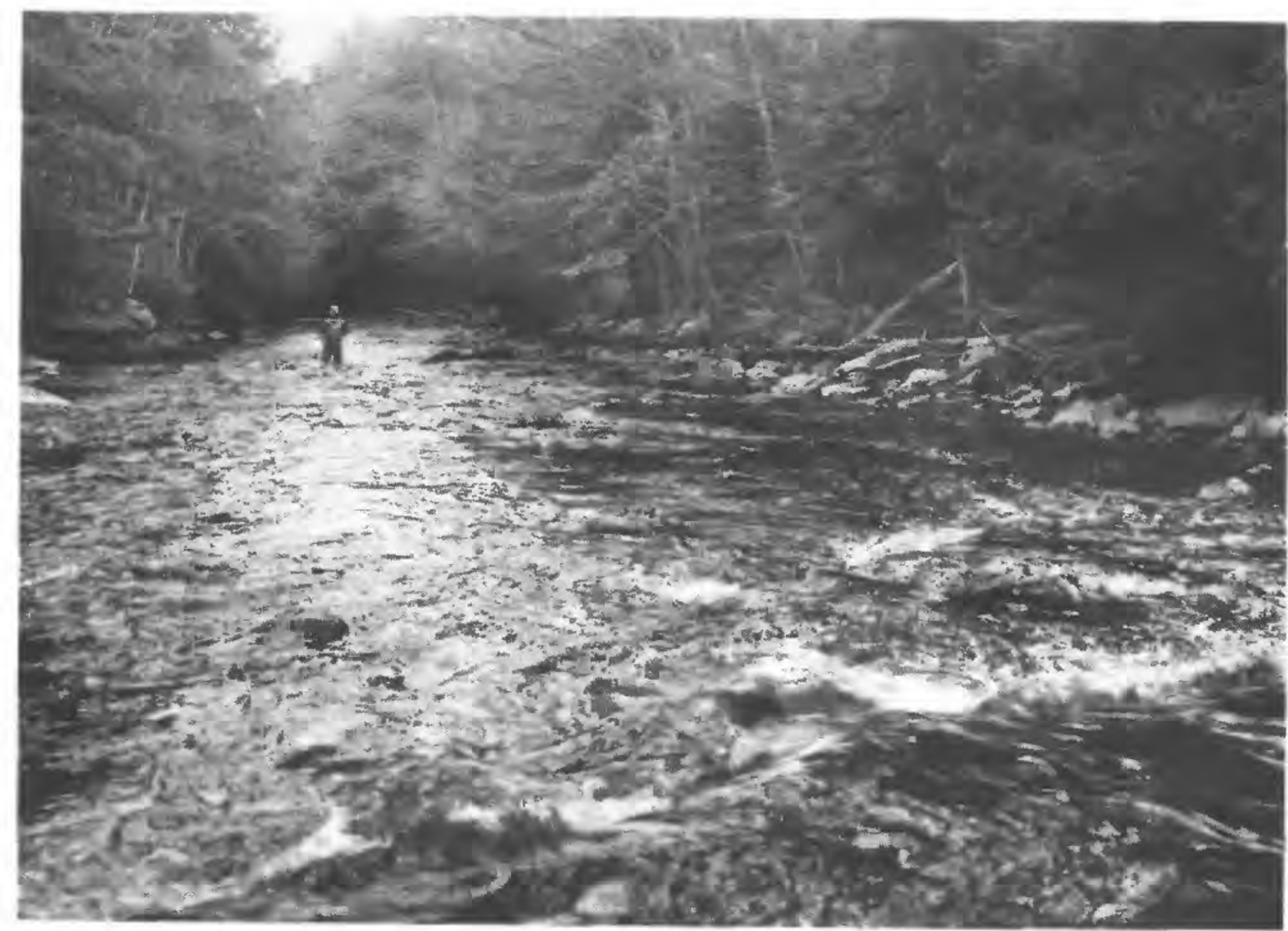

View from cross section 1, facing downstream toward right bank. Hydrographer is at section 2.

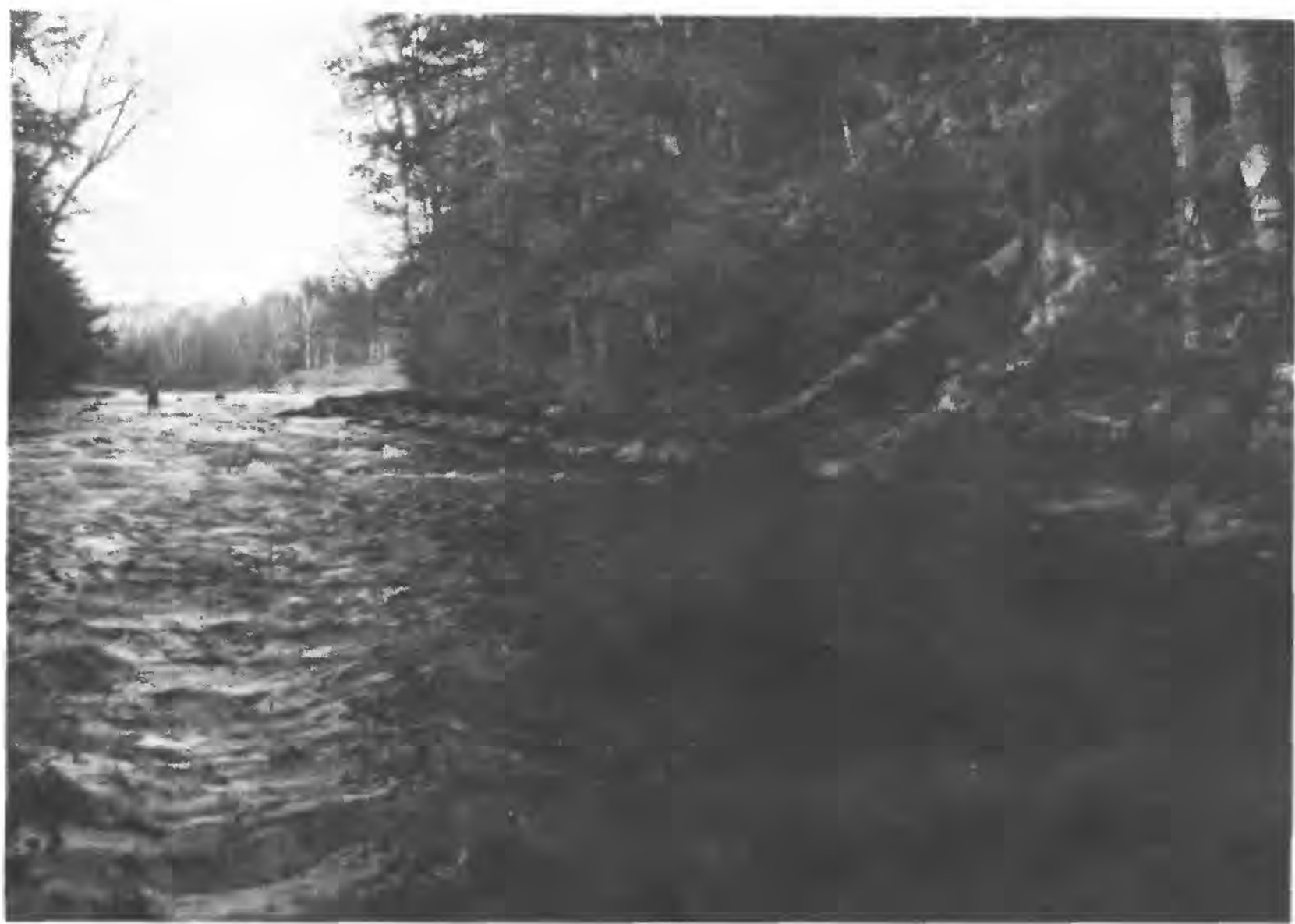

View from below cross section 2, facing upstream toward left bank. Hydrographer is at section 1.

Figure A2-11. Indian River near Indian Lake, N.Y. A. Photographs during late fall. Hydrographer is holding a 10-foot rod at approximate water-surface elevation of maximum recorded discharge. 


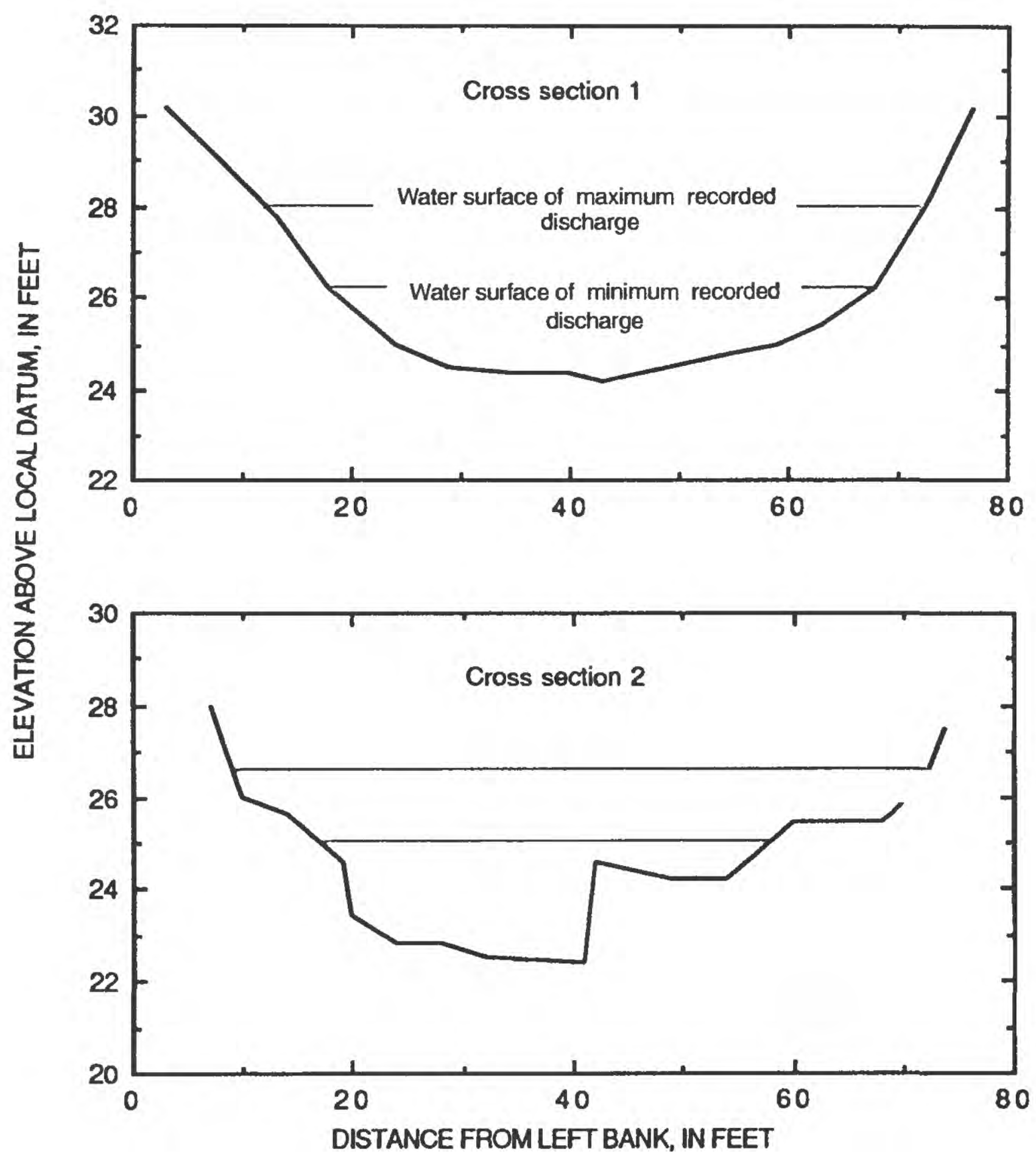

Flgure A2-11. Indian River near Indian Lake, N.Y. (continued).

B. Cross sections. (Locations are shown in plan view on p. 87.) 

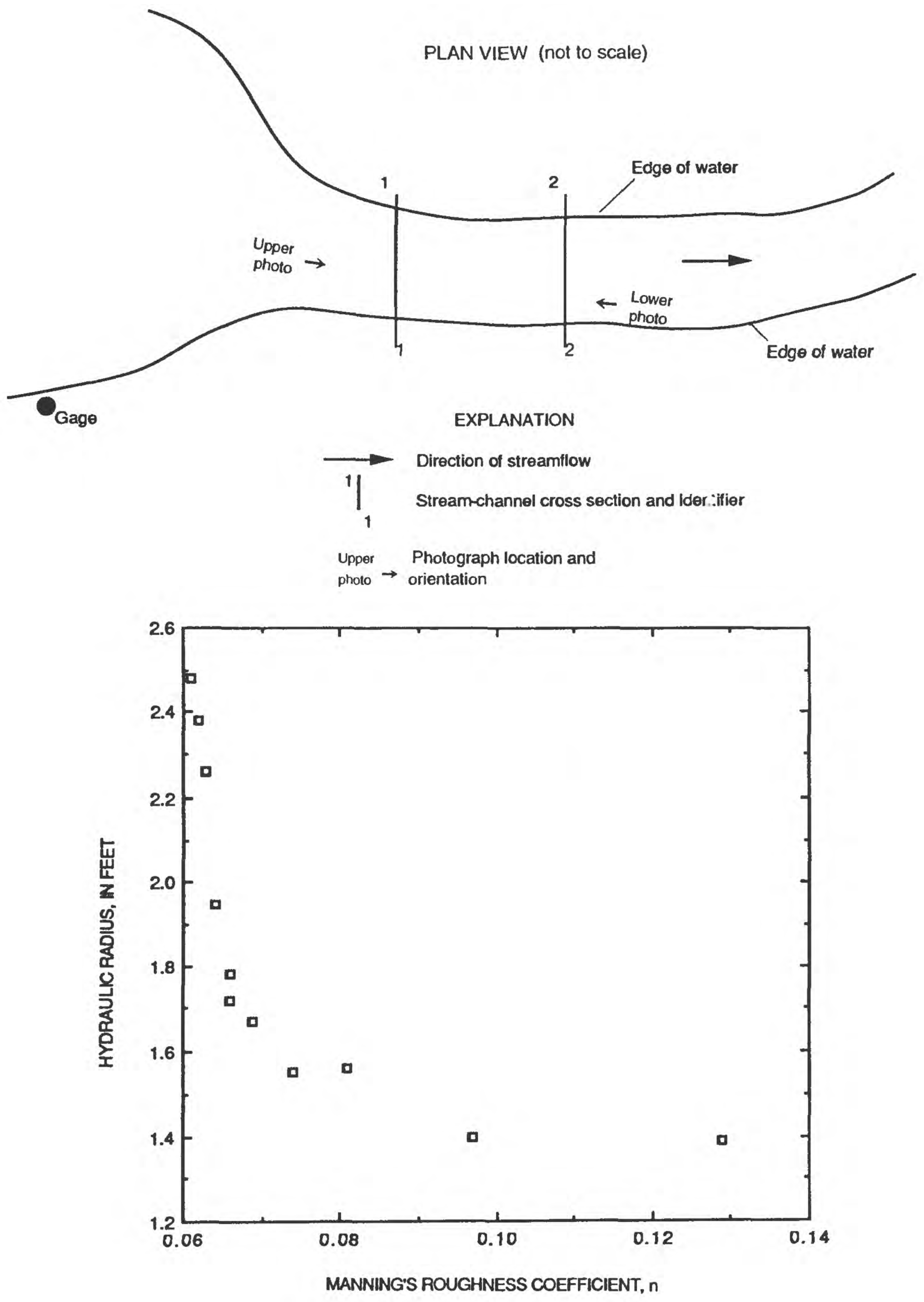

Figure A2-11. Indian River near Indian Lake, N.Y. (continued). and Manning's roughness coefficient .

C. Plan view and relation between hydraulic radius 


\section{SITE 12. SACANDAGA RIVER AT STEWARTS BRIDGE NEAR HADLEY, N.Y.}

Table A2-12. Station description and hydraulic data

Location.--Latitude $43^{\circ} 18^{\prime} 41^{\prime \prime}$, longitude $73^{\circ} 52^{\prime} 04^{\prime \prime}$, Saratoga County, on left bank 1.0 mi downstream from Stewarts Bridge, 1.1 mi west of Hadley, 1.4 mi upstream from mouth, and $1.5 \mathrm{mi}$ downstream from Stewarts Bridge hydroelectric plant. A 3-section, 420-ft-1ong reach; section 1 is $340 \mathrm{ft}$ downstream from gage.

USGS station-identification number.--01325000.

Drainage area.--1,055 $\mathrm{mi}^{2}$.

Bed material.--Primarily rounded cobbles. Intermediate diameter $\mathrm{d}_{50}=0.34 \mathrm{ft}$ and $\mathrm{d}_{84}=0.70 \mathrm{ft}$. Minimum diameter $\mathrm{d}_{50}=0.23 \mathrm{ft}$.

Bank description.--Both banks have dense tree growth, with 1 tree every 3 to $5 \mathrm{ft}$. Large trees from 2.5 to $3.0 \mathrm{ft}$ in diameter are surrounded by many smaller trees from 0.5 to $1.0 \mathrm{ft}$ in diameter. Little, if any, brush is growing among the trees. Vegetation indices: 2, 2.

Remarks.--Flow is regulated by Great Sacandaga Lake. The velocity-head coefficients computed from discharge measurements made at this site range from 1.39 to 1.26 for discharges between 4,000 and $13,000 \mathrm{ft}^{3} / \mathrm{s}$.

\section{Hydraulic Data}

$\left[\mathrm{ft}=\mathrm{feet} ; \mathrm{ft}^{2}=\right.$ square feet; $\mathrm{ft} / \mathrm{s}=$ feet per second; $\mathrm{ft}^{3} / \mathrm{s}=$ cubic feet per second. $]$

\begin{tabular}{|c|c|c|c|c|c|c|c|c|c|}
\hline \multirow[b]{2}{*}{$\begin{array}{c}\text { Discharge } \\
\left(\mathrm{ft}^{3} / \mathrm{s}\right)\end{array}$} & \multicolumn{5}{|c|}{ Average values for reach } & \multirow[b]{2}{*}{$\begin{array}{l}\text { Water- } \\
\text { surface } \\
\text { slope }\end{array}$} & \multirow[b]{2}{*}{$\begin{array}{l}\text { Energy } \\
\text { gradient }\end{array}$} & \multirow[b]{2}{*}{$\begin{array}{c}\text { Percent } \\
\text { wetted } \\
\text { perimeter } \\
\text { vegetated }\end{array}$} & \multirow[b]{2}{*}{$\begin{array}{c}\text { Manning's } \\
\mathrm{n}\end{array}$} \\
\hline & $\begin{array}{l}\text { Area } \\
\left(\mathrm{ft}^{2}\right)\end{array}$ & $\begin{array}{l}\text { Width } \\
\text { (ft) }\end{array}$ & $\begin{array}{l}\text { Hydraulic } \\
\text { radius } \\
\text { (ft) }\end{array}$ & $\begin{array}{c}\text { Velocity } \\
(\mathrm{ft} / \mathrm{s})\end{array}$ & $\begin{array}{l}\text { Froude } \\
\text { number }\end{array}$ & & & & \\
\hline$\ddagger 3,870$ & 1,320 & 273 & 4.83 & 2.93 & 0.23 & 0.00071 & 0.00072 & 0 & 0.039 \\
\hline$\ddagger 3,970$ & 1,350 & 273 & 4.91 & 2.95 & .23 & .00076 & .00076 & 0 & .041 \\
\hline$\$ 4,130$ & 1,370 & 273 & 4.99 & 3.02 & .24 & .00060 & .00060 & 0 & .036 \\
\hline$\ddagger 4,220$ & 1,380 & 273 & 5.01 & 3.07 & .24 & .00067 & .00067 & 0 & .037 \\
\hline 13,300 & 2,460 & 292 & 8.23 & 5.43 & .33 & .00174 & .00150 & 6.0 & .044 \\
\hline
\end{tabular}

$\ddagger$ The $\mathrm{n}$ value computed for this discharge and water-surface profile is affected by 11 to 13 percent flow-area expansion in the reach. The total water-surface fall is less than $0.33 \mathrm{ft}$. 


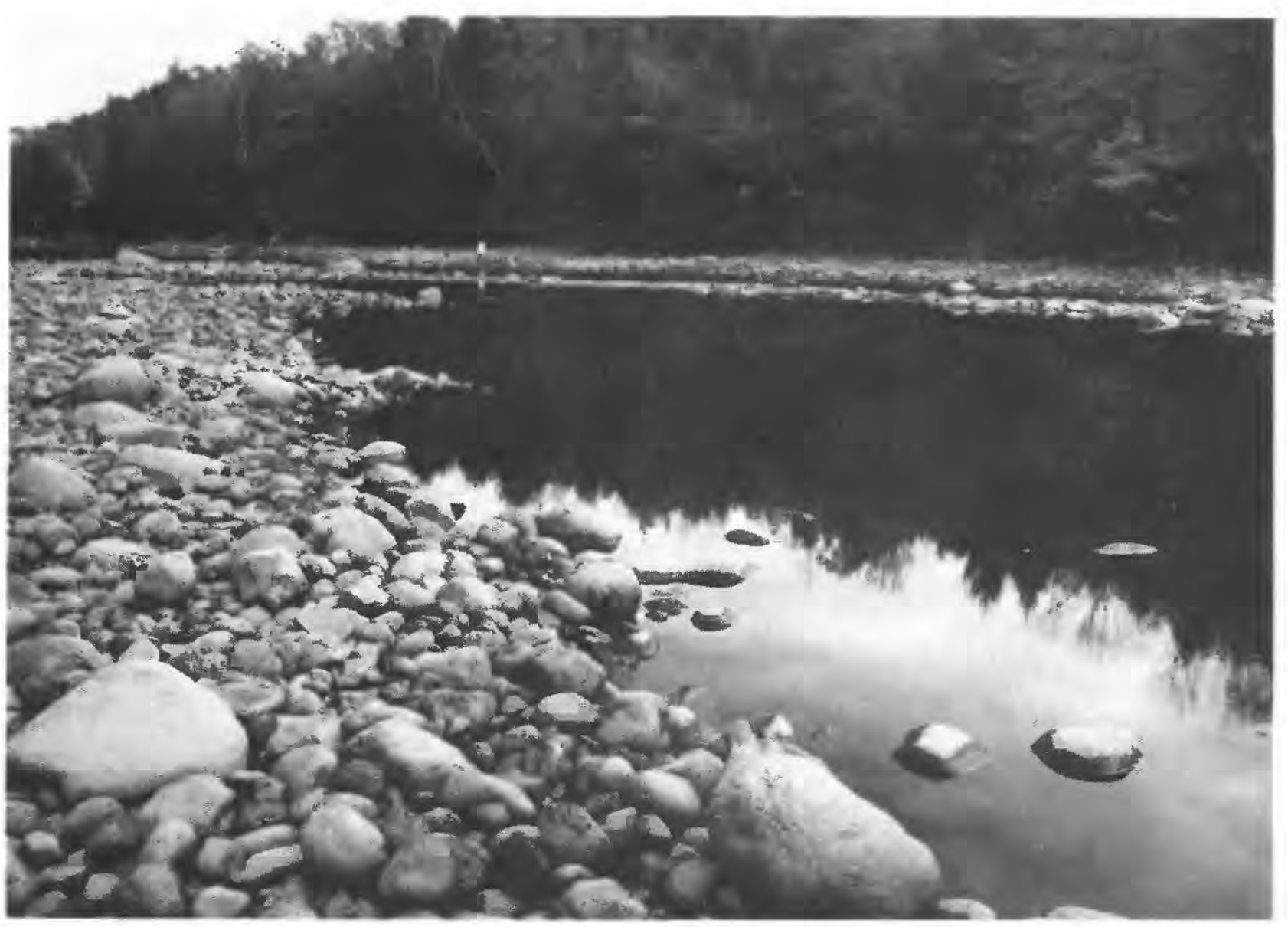

View from cross section 1, facing downstream toward right bank.

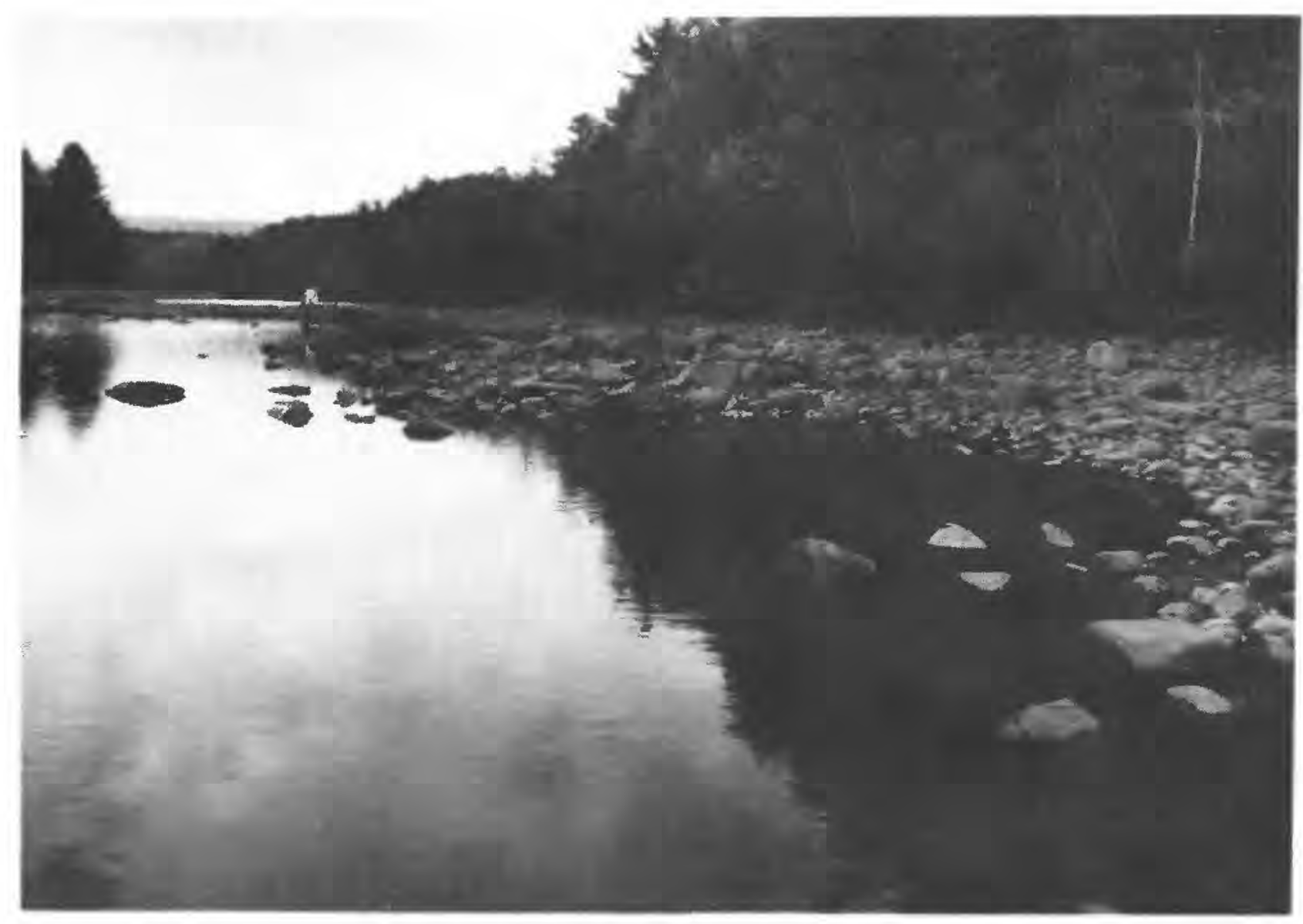

B. View from cross section 3 , facing upstream along left bank.

Figure A2-12. Sacandaga River at Stewarts Bridge near Hadley, N.Y. A. Photographs during late fall. Hydrographer is at section 2 holding a cross-section-identification card. 


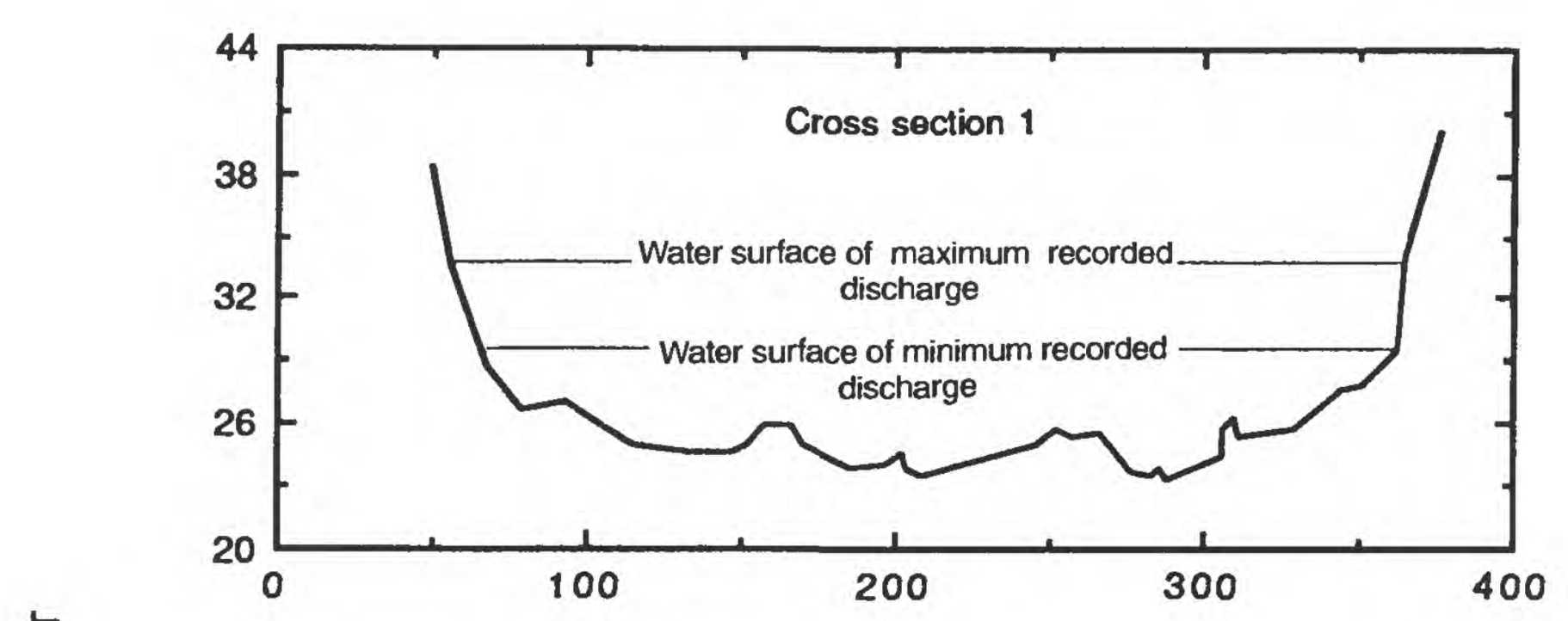

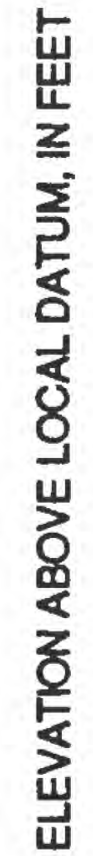
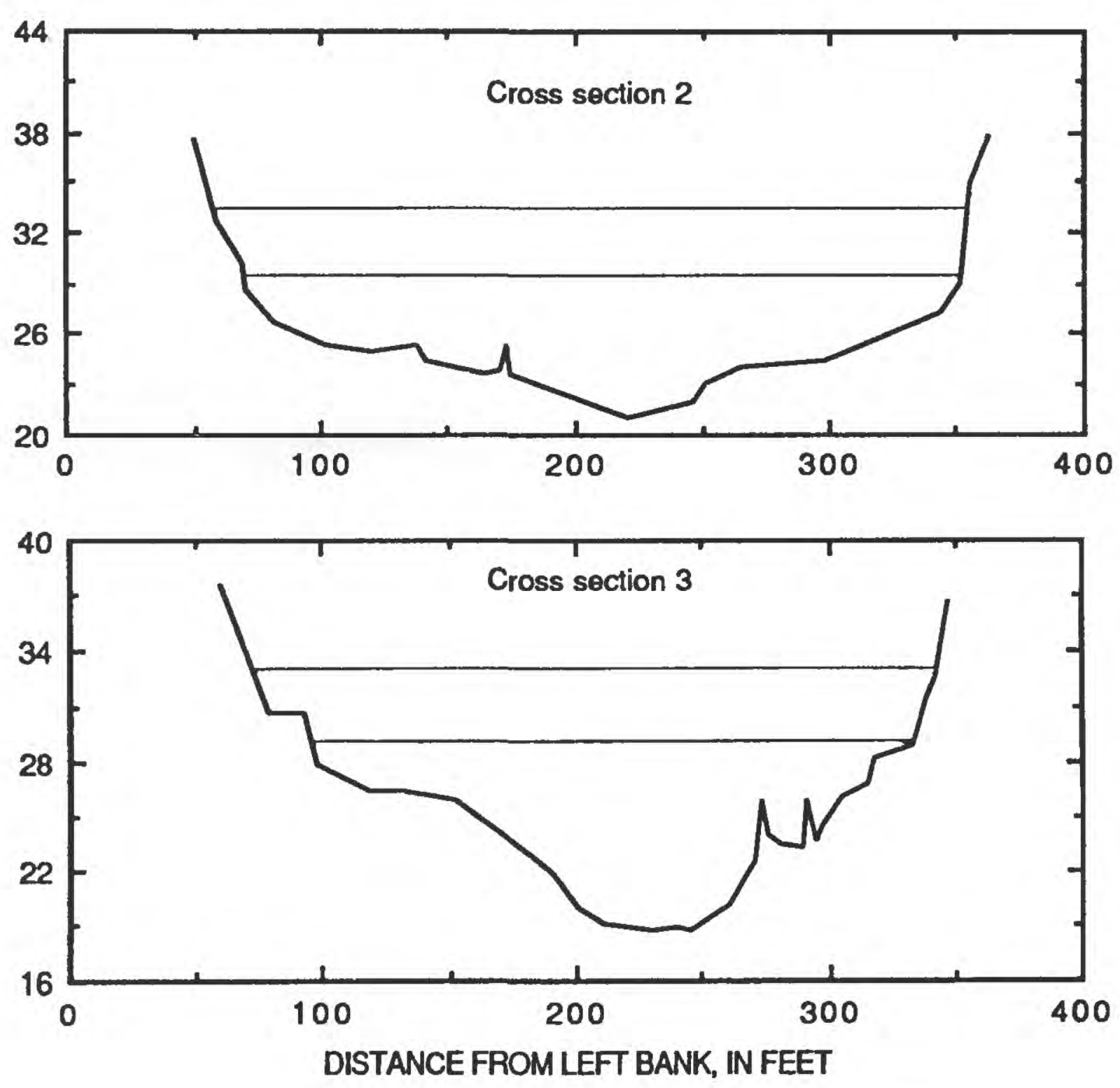

Figure A2-12. Sacandaga River at Stewarts Bridge near Hadley, N.Y. (continued). B. Cross sections. (Locations are shown in plan view on p. 91.) 


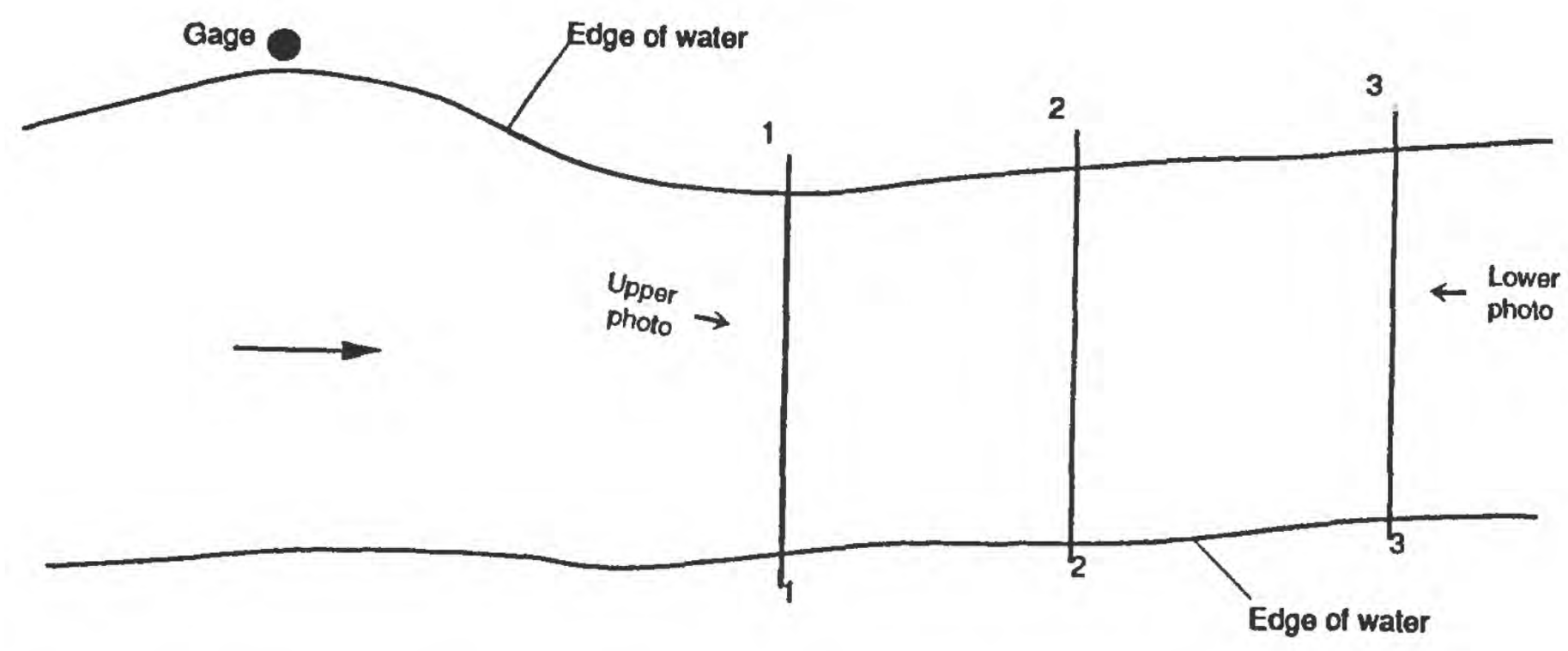

EXPLANATION
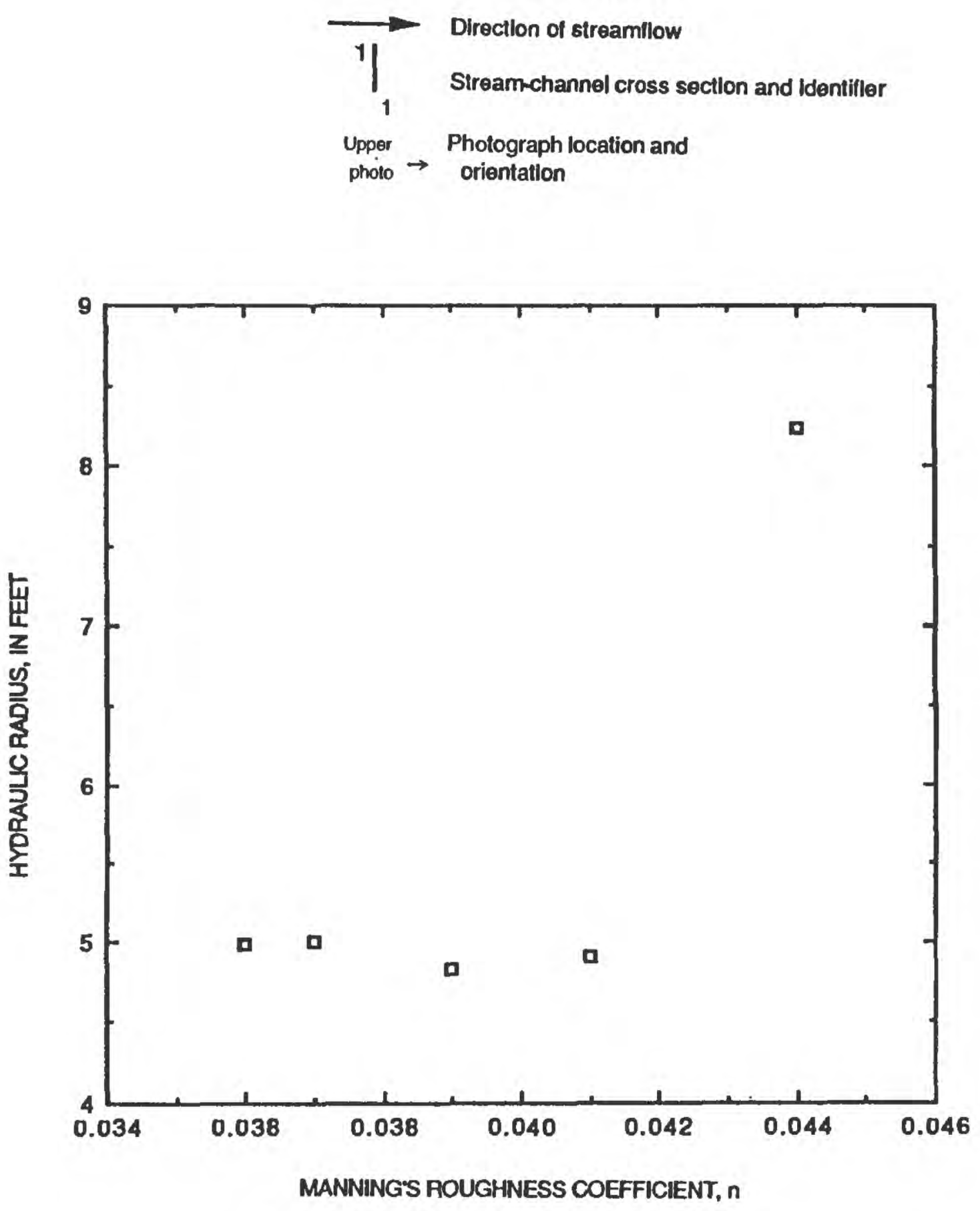

Figure A2-12. Sacandaga River at Stewarts Bridge near Hadley, N.Y. (continued). C. Plan view and relation between hydraulic radius and Manning's roughness coefficient . 


\section{SITE 13. ESOPUS CREEK AT COLDBROOK, N.Y.}

Table A2-13. Station description and hydraulic data

Location.--Latitude $42^{\circ} 00^{\prime} 51^{\prime \prime}$, longitude $74^{\circ} 16^{\prime} 16^{\prime \prime}$, Ulster County, on left bank at downstream side of bridge on Coldbrook Road in Coldbrook, $0.3 \mathrm{mi}$ downstream from Little Beaver Kill, $1.5 \mathrm{mi}$ upstream from Ashokan Reservoir, and $2.5 \mathrm{mi}$ south of Mount Tremper. A 3-section, 412-ft-long reach; section 1 is at the gage.

USGS station-identification number.--01362500.

Drainage area. $-192 \mathrm{mi}^{2}$.

Bed material.--Large cobbles and boulders as much as $8 \mathrm{ft}$ in diameter. Intermediate diameter $\mathrm{d}_{50}=1.1 \mathrm{ft}$ and $\mathrm{d}_{84}=3.0 \mathrm{ft}$. Minimum diameter $\mathrm{d}_{50}=0.80 \mathrm{ft}$.

Bank description.--Both banks are vegetated with brush and trees. Large trees, greater than $1.5 \mathrm{ft}$ in diameter, are interspersed among smaller ones, 0.5 to $1.5 \mathrm{ft}$ in diameter, the resulting tree density is 1 tree every $5 \mathrm{ft}$. The brush is denser on the right bank than on the left bank. Vegetation indices: 3,4 .

Previous n-value computations.--The roughness coefficient was computed for the flood of March 22, 1948 at two sites on this stream. The first site is just upstream of the present study site; the second is upstream of route $28 \mathrm{~A}$, about $6 \mathrm{mi}$ downstream of the gage. Ashokan Reservoir lies between these two sites. The data for these n-value computations, taken from Barnes (1967), are included in the following table.

Remarks.--The velocity-head coefficients computed from discharge measurements made at this site range from 1.12 to 1.29 for discharges between 2,000 and $32,000 \mathrm{ft}^{3} / \mathrm{s}$.

\section{Hydraulic Data}

$\left[\mathrm{ft}=\mathrm{feet} ; \mathrm{ft}^{2}=\right.$ square feet; $\mathrm{ft} / \mathrm{s}=$ feet per second; $\mathrm{ft}^{3} / \mathrm{s}=$ cubic feet per second. $]$

\begin{tabular}{|c|c|c|c|c|c|c|c|c|c|}
\hline \multirow[b]{2}{*}{$\begin{array}{c}\text { Discharge } \\
\left(\mathrm{ft}^{3} / \mathrm{s}\right)\end{array}$} & \multicolumn{5}{|c|}{ Average values for reach } & \multirow[b]{2}{*}{$\begin{array}{l}\text { Water- } \\
\text { surface } \\
\text { slope }\end{array}$} & \multirow[b]{2}{*}{$\begin{array}{l}\text { Energy } \\
\text { gradient }\end{array}$} & \multirow[b]{2}{*}{$\begin{array}{c}\text { Percent } \\
\text { wetted } \\
\text { perimeter } \\
\text { vegetated }\end{array}$} & \multirow[b]{2}{*}{$\underset{n}{\text { Manning's }}$} \\
\hline & $\begin{array}{l}\text { Area } \\
\left(\mathrm{ft}^{2}\right)\end{array}$ & $\begin{array}{l}\text { Width } \\
\text { (ft) }\end{array}$ & $\begin{array}{l}\text { Hydraulic } \\
\text { radius } \\
\text { (ft) }\end{array}$ & $\begin{array}{l}\text { Velocity } \\
\text { (ft/s) }\end{array}$ & $\begin{array}{l}\text { Froude } \\
\text { number }\end{array}$ & & & & \\
\hline 2,240 & 561 & 153 & 3.60 & 4.02 & 0.37 & 0.00328 & 0.00306 & 0 & 0.050 \\
\hline 5,520 & 904 & 170 & 5.20 & 6.12 & .47 & .00374 & .00339 & 0 & .043 \\
\hline$* 6,140$ & 985 & 174 & 5.56 & 6.24 & .46 & .00374 & .00343 & 0 & .044 \\
\hline$* 8,700$ & 1,190 & 180 & 6.44 & 7.34 & .50 & .00391 & .00358 & 2.7 & .042 \\
\hline 9,030 & 1,160 & 179 & 6.33 & 7.79 & .54 & .00405 & .00363 & 2.2 & .039 \\
\hline 12,200 & 1,410 & 186 & 7.38 & 8.66 & .56 & .00415 & .00378 & 5.7 & .040 \\
\hline 37,400 & 2,650 & 213 & 11.96 & 14.13 & .71 & .00459 & .00434 & 18.9 & .036 \\
\hline 51,700 & 3,090 & 220 & 13.42 & 16.75 & .79 & .00500 & .00437 & 21.7 & .034 \\
\hline${ }^{\mathrm{a}} 13,900$ & 1,460 & 178 & 8.12 & 9.46 & .58 & .00446 & ----- & -- & .043 \\
\hline${ }^{b} 13,900$ & 1,590 & 292 & 5.41 & 8.74 & .66 & .00340 & ----- & - & .030 \\
\hline
\end{tabular}

* The data used for this $\mathrm{n}$-value calculation were collected during the growing season.

${ }^{a}$ From Barnes (1967). Site is at gage.

${ }^{\mathrm{b}}$ From Barnes (1967). Site is about 6 miles downstream of gage. 


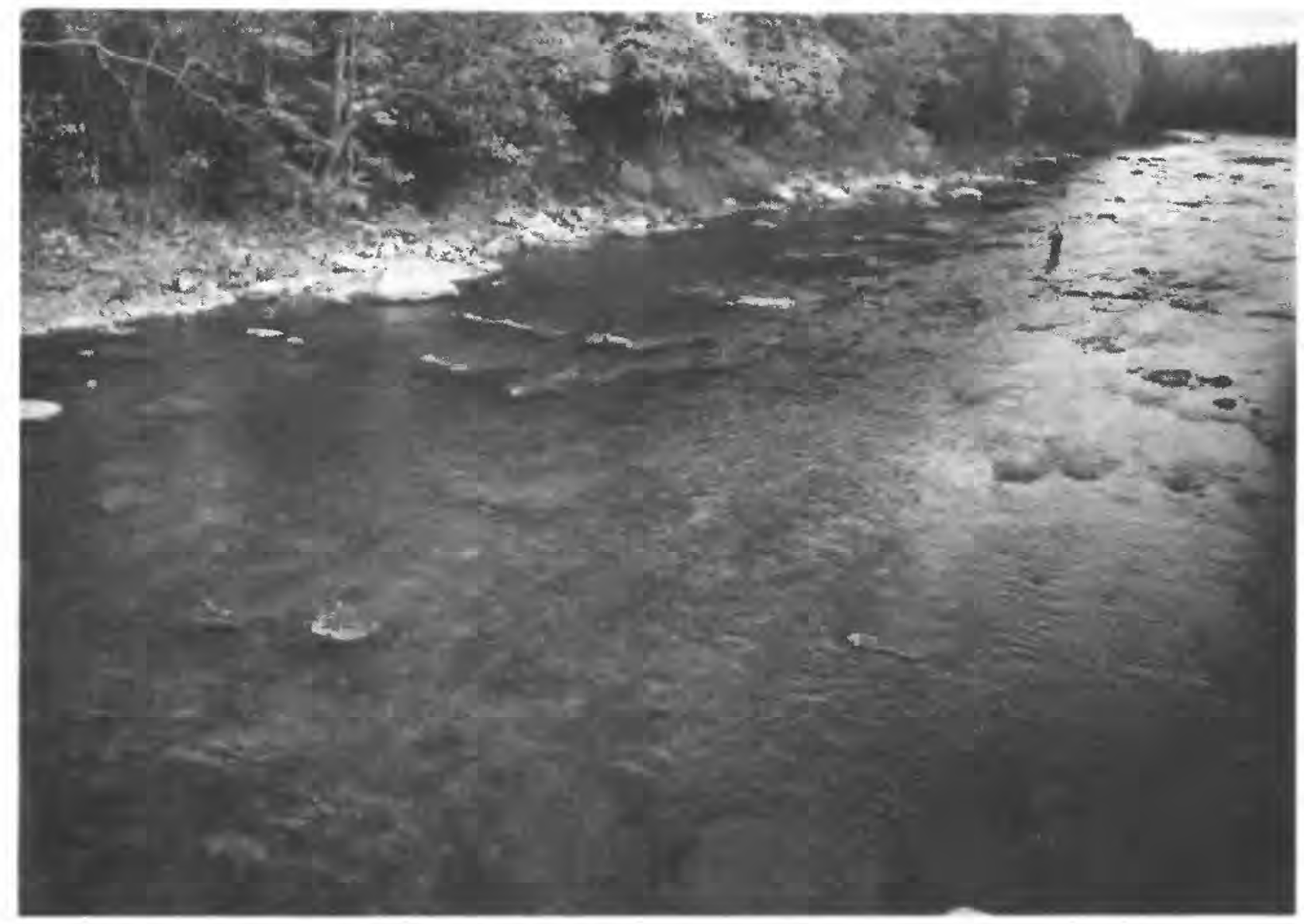

View from cross section 1, facing downstream toward left bank.

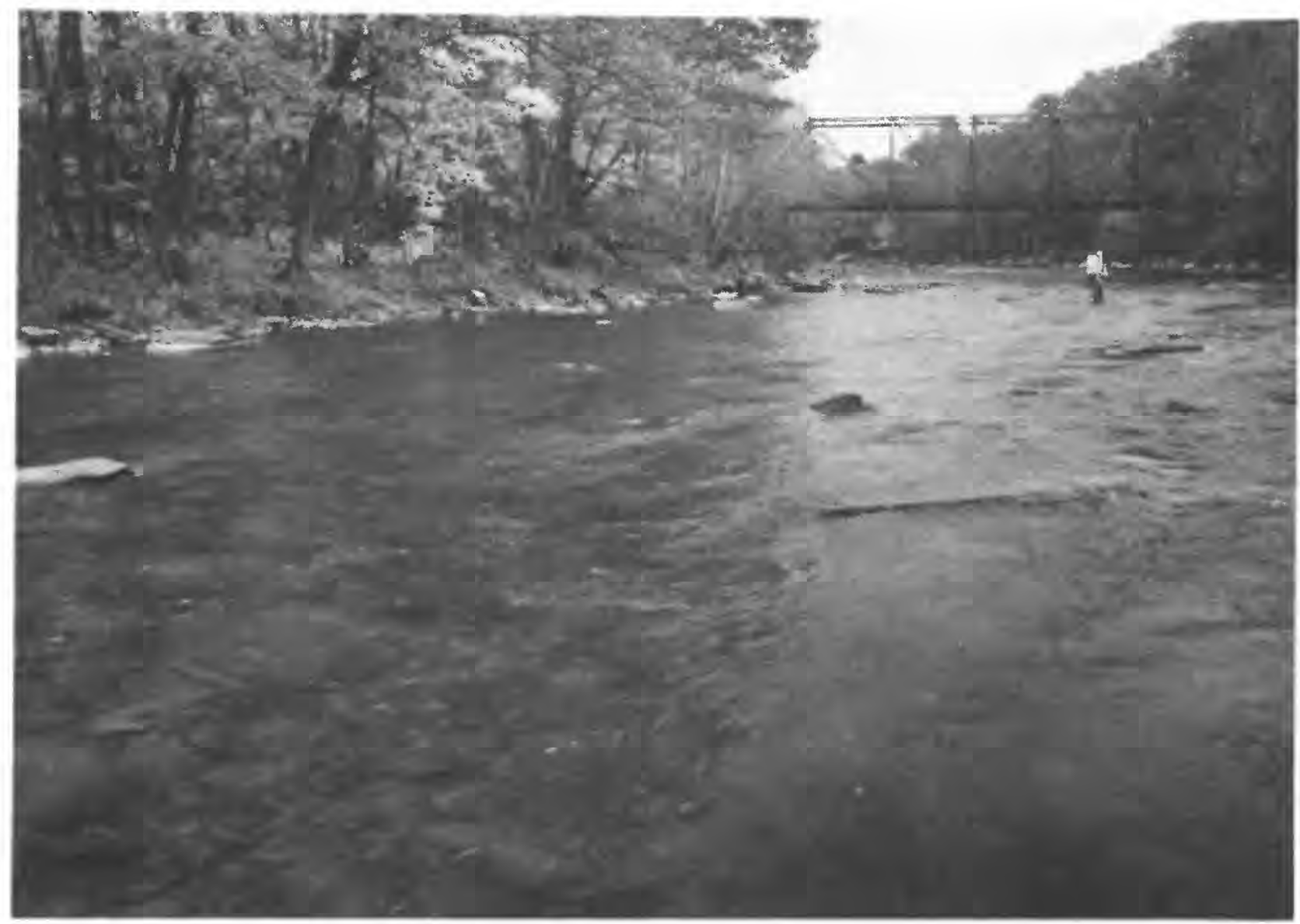

View from cross section 3 , facing upstream toward right bank.

Figure A2-13. Esopus Creek at Coldbrook, N.Y. A. Photographs during late fall. Hydrographer is at section 2. 


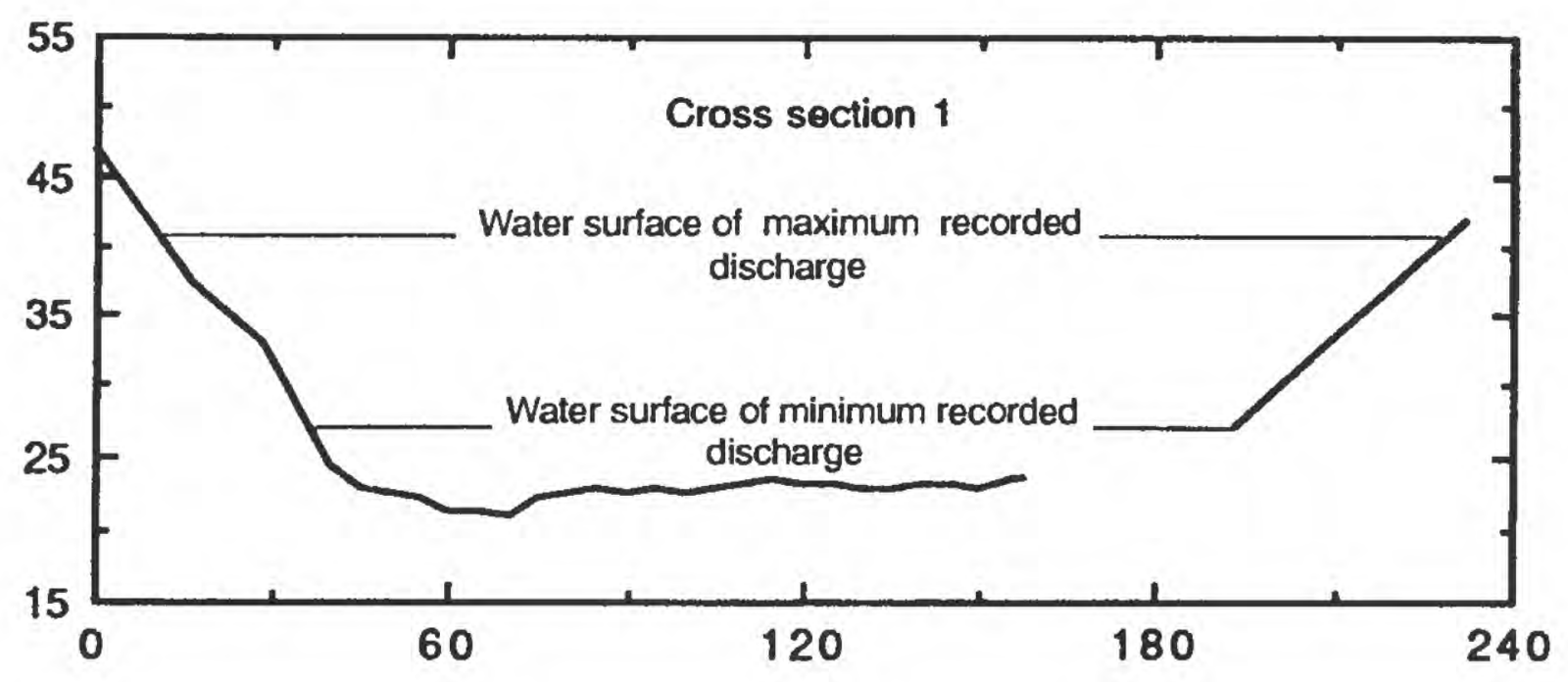

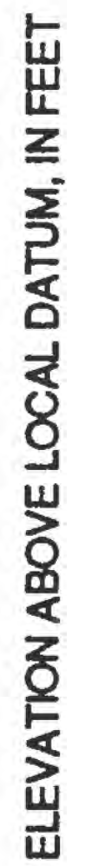
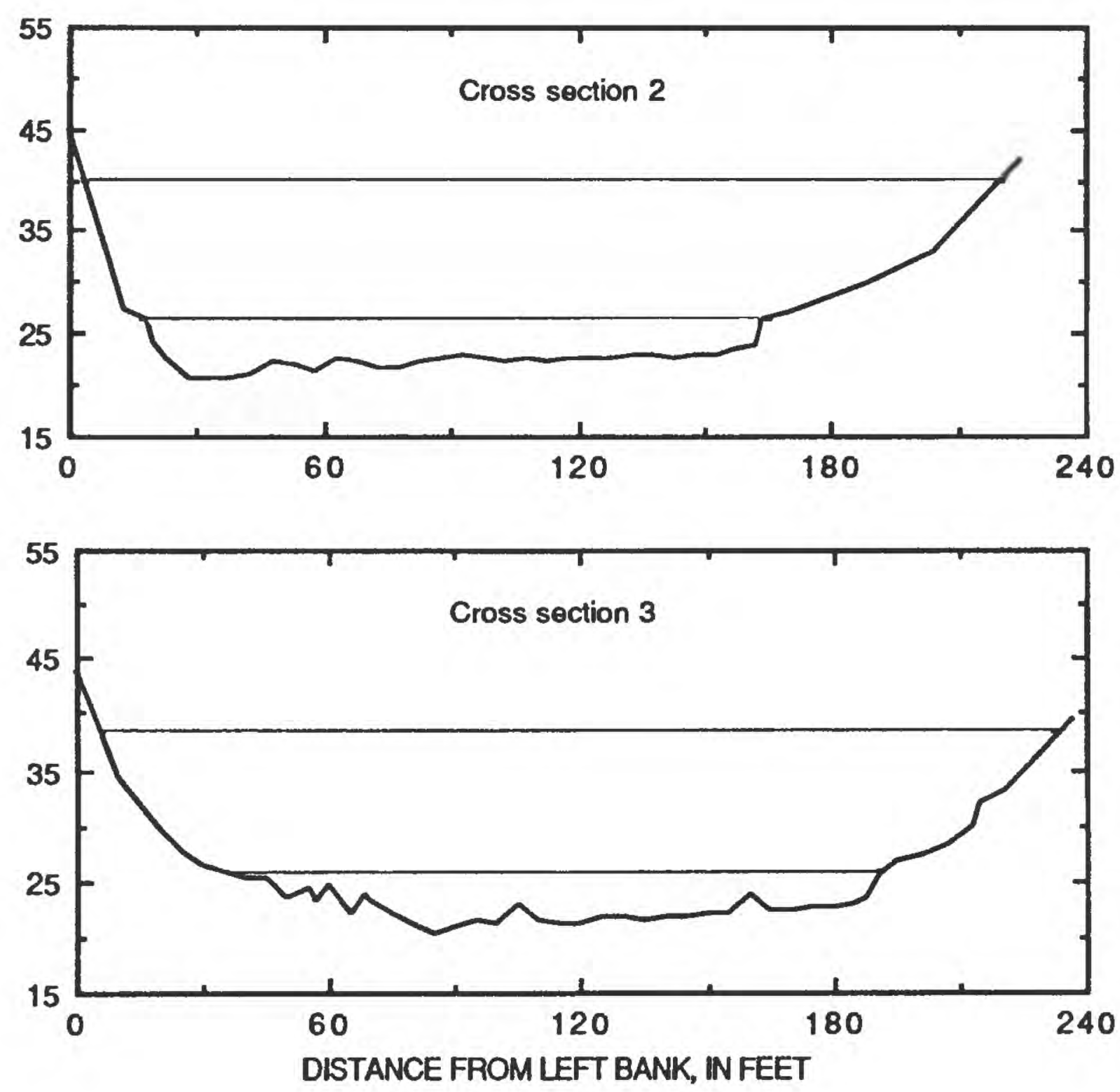

Figure A2-13. Esopus Creek at Coldbrook, N.Y. (continued). B. Cross sections. (Locations are shown in plan view on p. 95.) 
PLAN VIEW (not to scale)

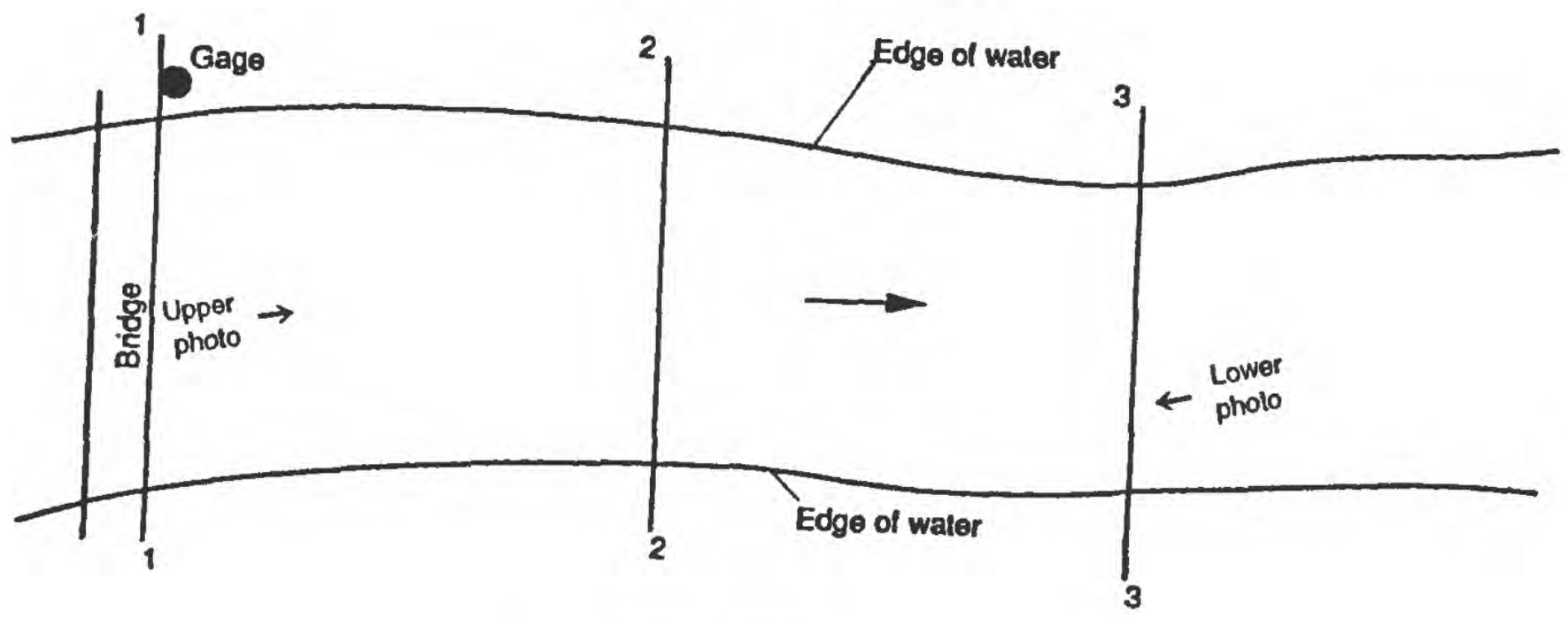

EXPLANATION
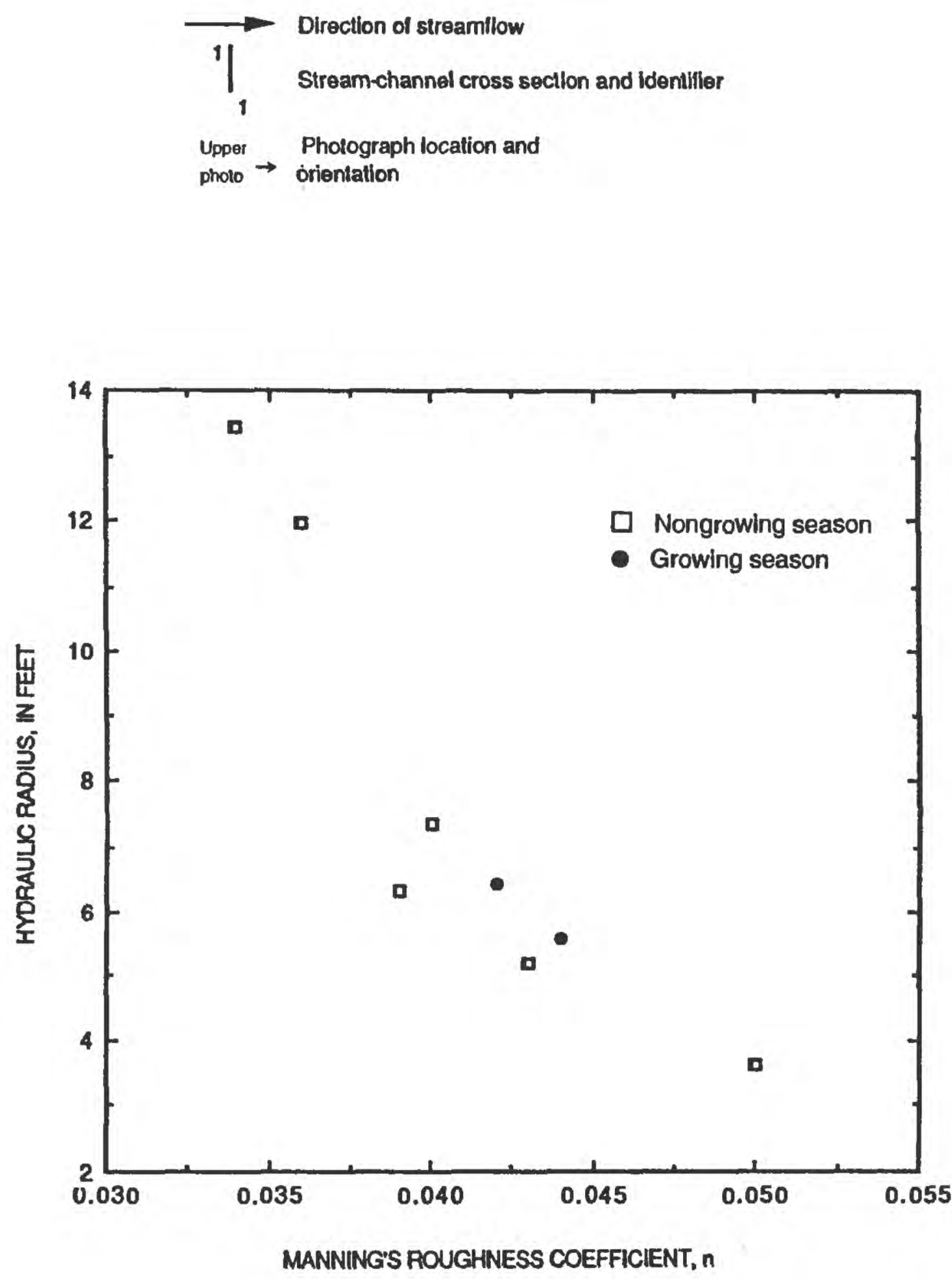

Figure A2-13. Esopus Creek at Coldbrook, N.Y. (continued). C. Plan view and relation between hydraulic radius and Manning's roughness coefficient during growing and nongrowing seasons. 


\section{SITE 14. EAST BRANCH DELAWARE RIVER AT MARGARETVILLE, N.Y.}

Table A2-14. Station description and hydraulic data

Location.--Latitude $42^{\circ} 08^{\prime} 41^{\prime \prime}$, longitude $74^{\circ} 39^{\prime} 14^{\prime \prime}$, Delaware County, on right bank at downstream side of bridge on Fair Street at intersection with Main Street at Margaretville, 0.2 mi upstream from unnamed tributary, and $1.6 \mathrm{mi}$ downstream from Dry Brook. A 3-section, 354-ft-long reach; section 1 is $190 \mathrm{ft}$ downstream from bridge on Fair Street.

USGS station-identification number.--01413500.

Drainage area.--163 $\mathrm{mi}^{2}$.

Bed material.--Gravel and cobbles. Intermediate diameter $\mathrm{d}_{50}=0.28 \mathrm{ft}$ and $\mathrm{d}_{84}=0.44 \mathrm{ft}$. Minimum diameter $\mathrm{d}_{50}=0.09 \mathrm{ft}$.

Bank description.--Both banks have dense brush with a few sparsely spaced trees, mostly 1.0 to $1.5 \mathrm{ft}$ in diameter. Vegetation indices: $1,2$.

\section{Hydraulic Data}

$\left[\mathrm{ft}=\mathrm{fcct} ; \mathrm{ft}^{2}=\right.$ square feet; $\mathrm{ft} / \mathrm{s}=$ feet per second; $\mathrm{ft}^{3} / \mathrm{s}=$ cubic feet per second. $]$

\begin{tabular}{|c|c|c|c|c|c|c|c|c|c|}
\hline \multirow[b]{2}{*}{$\begin{array}{c}\text { Discharge } \\
\left(\mathrm{ft}^{3} / \mathrm{s}\right)\end{array}$} & \multicolumn{5}{|c|}{ Average values for reach } & \multirow[b]{2}{*}{$\begin{array}{l}\text { Water- } \\
\text { surface } \\
\text { slope }\end{array}$} & \multirow[b]{2}{*}{$\begin{array}{l}\text { Energy } \\
\text { gradient }\end{array}$} & \multirow[b]{2}{*}{$\begin{array}{c}\text { Percent } \\
\text { wetted } \\
\text { perimeter } \\
\text { vegetated }\end{array}$} & \multirow[b]{2}{*}{$\begin{array}{c}\text { Manning's } \\
\text { n }\end{array}$} \\
\hline & $\begin{array}{c}\text { Area } \\
\left(\mathrm{ft}^{2}\right)\end{array}$ & $\begin{array}{l}\text { Width } \\
\text { (ft) }\end{array}$ & $\begin{array}{l}\text { Hydraulic } \\
\text { radius } \\
\text { (ft) }\end{array}$ & $\begin{array}{c}\text { Velocity } \\
(\mathrm{ft} / \mathrm{s})\end{array}$ & $\begin{array}{l}\text { Froude } \\
\text { number }\end{array}$ & & & & \\
\hline 1,420 & 330 & 105 & 3.08 & 4.30 & 0.43 & 0.00209 & 0.00204 & 0.9 & 0.034 \\
\hline 1,840 & 388 & 108 & 3.53 & 4.75 & .44 & .00212 & .00203 & 3.6 & .033 \\
\hline${ }^{a} 1,990$ & 451 & 109 & 4.05 & 4.41 & .38 & .00138 & .00130 & 5.4 & .031 \\
\hline 2,100 & 417 & 110 & 3.75 & 5.03 & .45 & .00203 & .00195 & 5.4 & .032 \\
\hline$* 2,860$ & 530 & 114 & 4.58 & 5.39 & .44 & .00209 & .00196 & 8.6 & .034 \\
\hline 6,600 & 905 & 129 & 6.80 & 7.30 & .49 & .00240 & .00198 & 20.3 & .033 \\
\hline
\end{tabular}

* The data used for this $\mathrm{n}$-value calculation werc collected during the growing season.

${ }^{a}$ Post-April 1987 flood; new channel geometry and stage-to-discharge relation. 


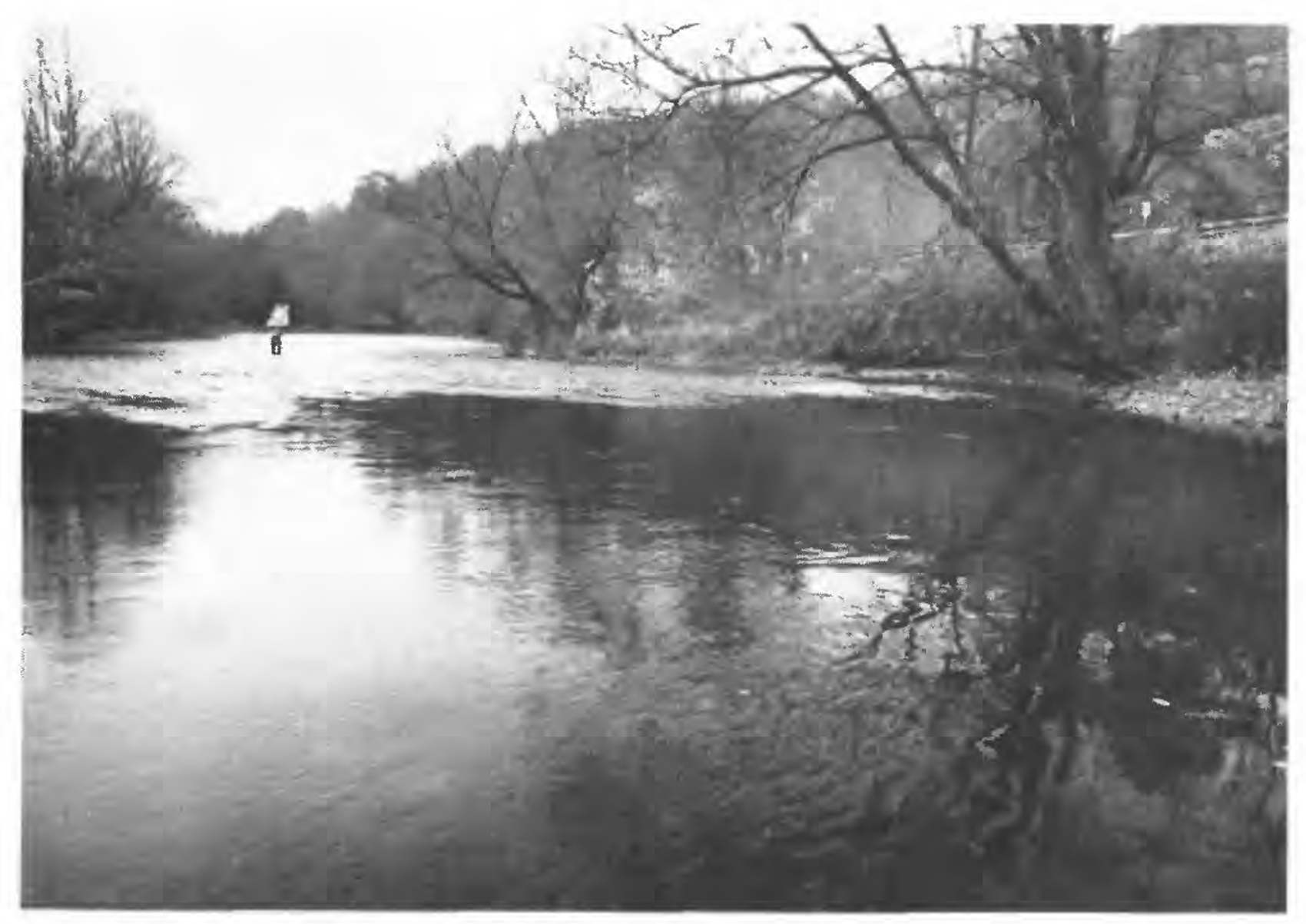

View from cross section 1, facing downstream toward right bank.

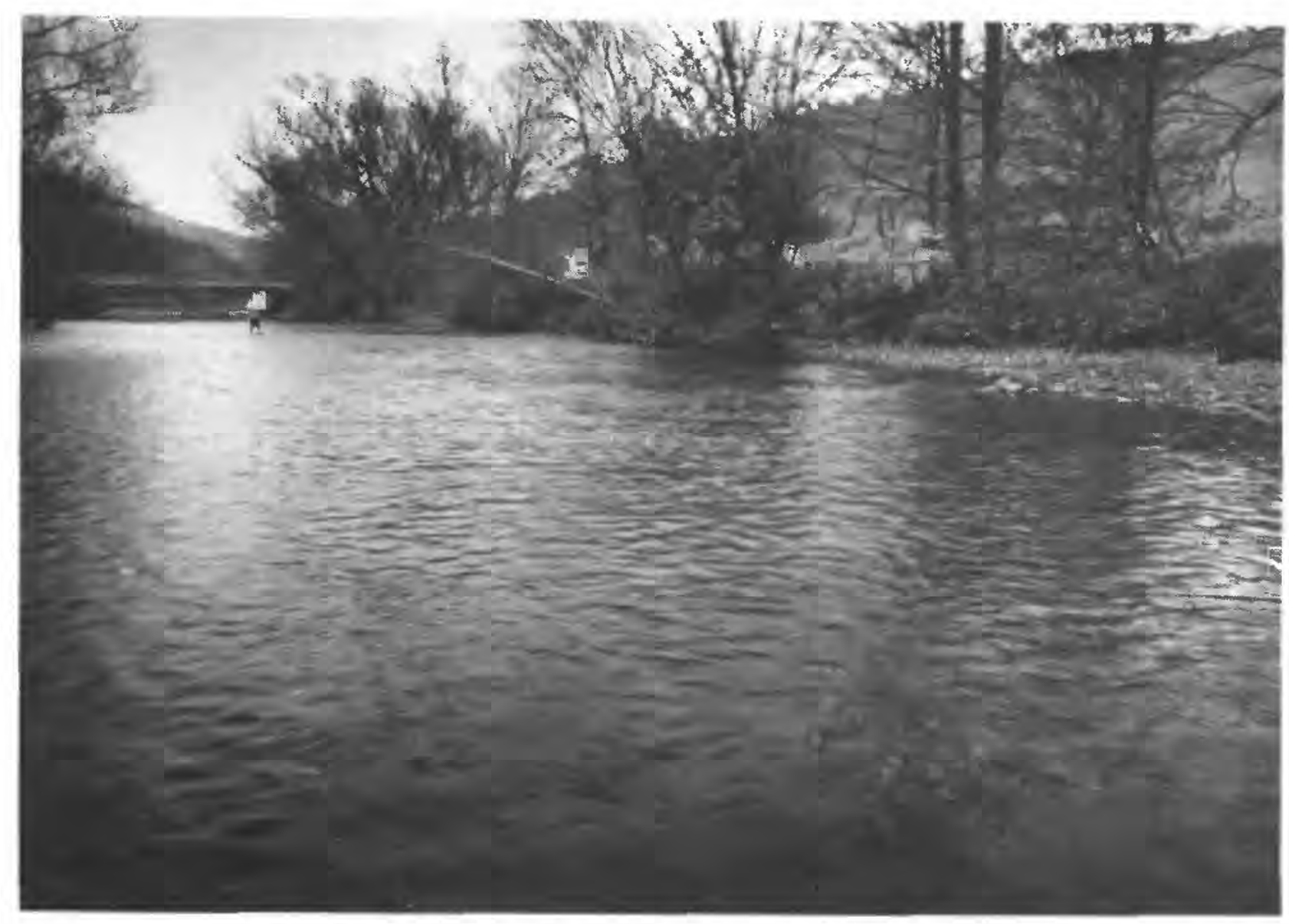

View from cross section 3 , facing upstream toward left bank.

Figure A2-14. East Branch Delaware River at Margaretville, N.Y. A. Photographs during late fall. Hydrographer is at section 2. 


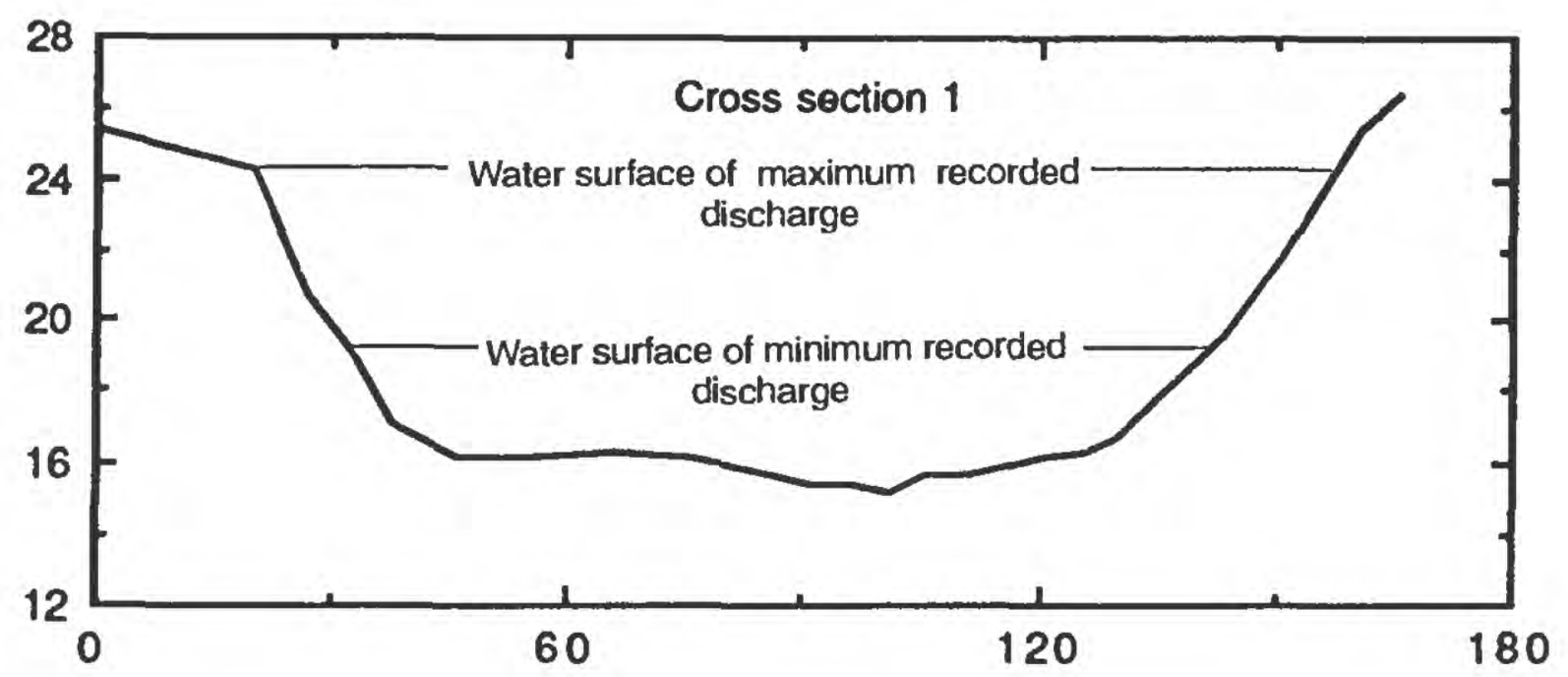

䒚
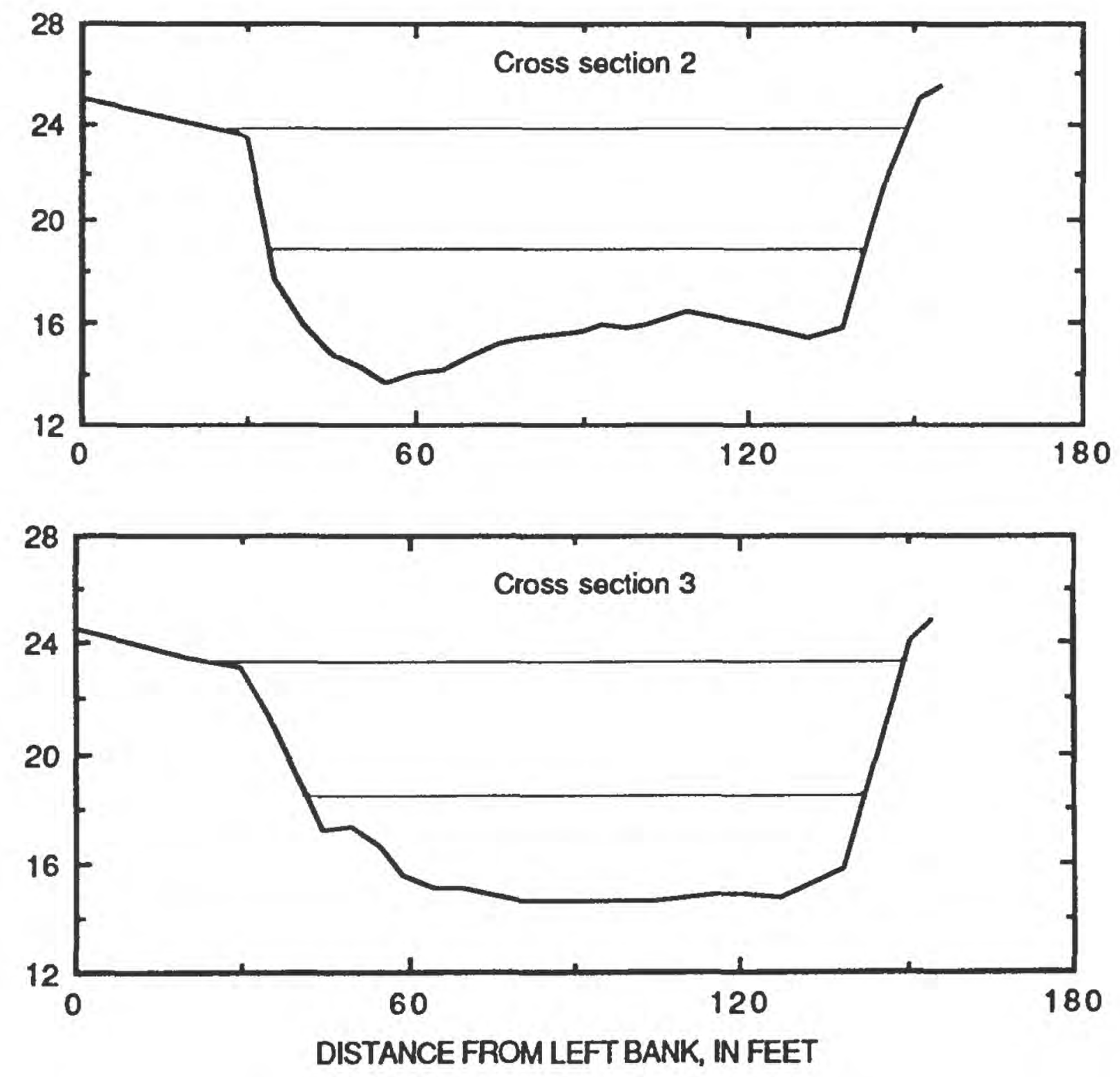

Flgure A2-14. East Branch Delaware River at Margaretville, N.Y. (continued). B. Cross sections. (Locations are shown in plan view on p. 99.) 
PLAN VIEW (not to scale)

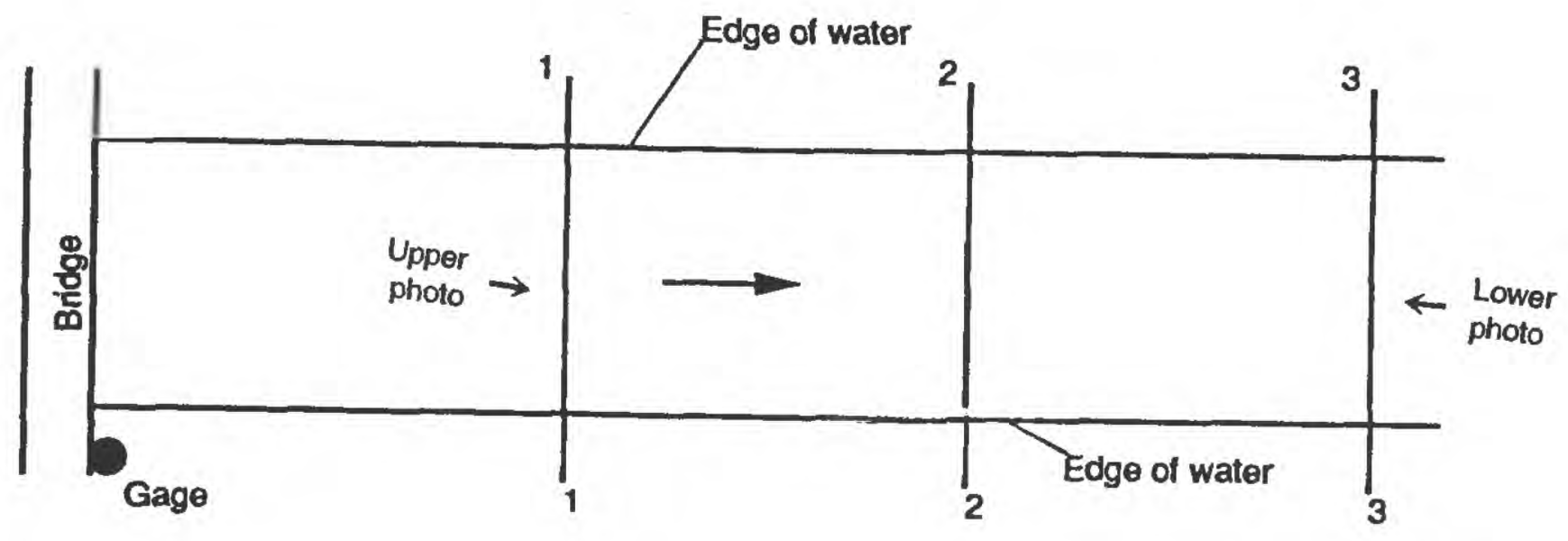

EXPLANATION
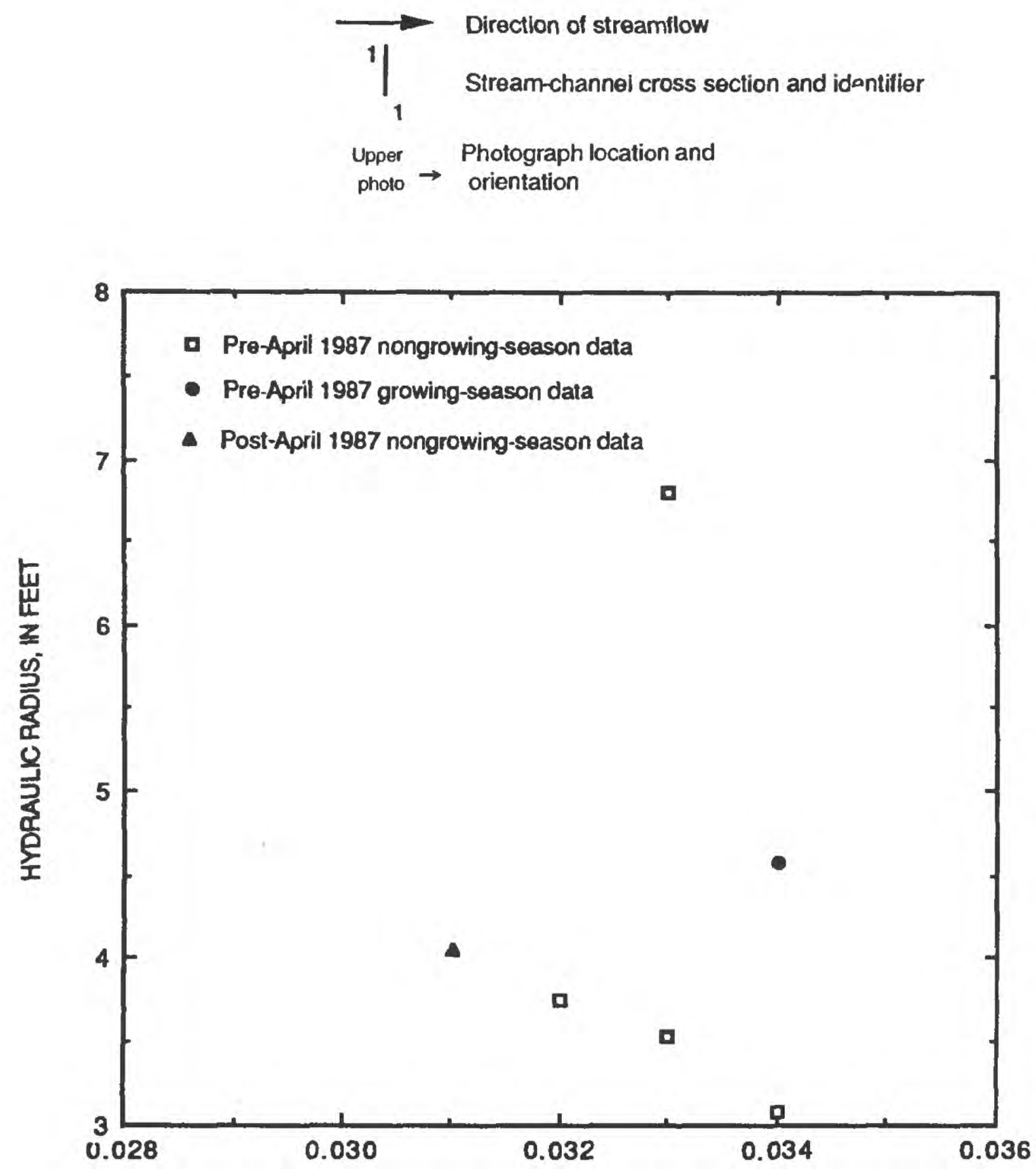

MANNING'S ROUGHNESS COEFFICIENT, $n$

Figure A2-14. East Branch Delaware River at Margaretville, N.Y. (continued). C. Plan view and relation between hydraulic radius and Manning's roughness coefficient during growing and nongrowing seasons. 


\section{SITE 15. OULEOUT CREEK AT EAST SIDNEY, N.Y.}

Table A2-15. Station description and hydraulic data

Location.--Latitude $42^{\circ} 20^{\prime} 00^{\prime \prime}$, longitude $75^{\circ} 14^{\prime} 07^{\prime \prime}$, Delaware County, on right bank 0.2 mi downstream from bridge on County Highway 44, 0.4 mi downstream from East Sidney Dam, at East Sidney, and $3.5 \mathrm{mi}$ upstream from mouth. A 3-section, 345-ft-long reach; section 1 is at the gage.

USGS station-identification number.--01500000.

Drainage area.-- $103 \mathrm{mi}^{2}$.

Bed material.--Cobbles and small boulders, mostly flat. Intermediate diameter $\mathrm{d}_{50}=0.41 \mathrm{ft}$ and $\mathrm{d}_{84}=1.43 \mathrm{ft}$. Minimum diameter $\mathrm{d}_{50}=0.12 \mathrm{ft}$.

Bank description.--Both banks have tall summer grasses and scattered trees of varying diameters. Left bank is steep and has denser brush and fewer trees than the right bank. Hummocky grasses are in center of channel between cross sections 1 and 2. Vegetation indices: 1,2 .

Remarks.--Flow is regulated by East Sidney Lake. The velocity-head coefficients computed from discharge measurements made at this site range from 1.19 to 1.30 for discharges between 900 and $1,700 \mathrm{ft}^{3} / \mathrm{s}$.

\section{Hydraulic Data}

$\left[\mathrm{ft}=\mathrm{feet} ; \mathrm{ft}^{2}=\right.$ square $\mathrm{fcet} ; \mathrm{ft} / \mathrm{s}=$ feet per second; $\mathrm{ft}^{3} / \mathrm{s}=$ cubic feet per second. $]$

\begin{tabular}{|c|c|c|c|c|c|c|c|c|c|}
\hline \multirow[b]{2}{*}{$\begin{array}{c}\text { Discharge } \\
\left(\mathrm{ft}^{3} / \mathrm{s}\right)\end{array}$} & \multicolumn{5}{|c|}{ Average values for reach } & \multirow[b]{2}{*}{$\begin{array}{l}\text { Water- } \\
\text { surface } \\
\text { slope }\end{array}$} & \multirow[b]{2}{*}{$\begin{array}{l}\text { Energy } \\
\text { gradient }\end{array}$} & \multirow[b]{2}{*}{$\begin{array}{c}\text { Percent } \\
\text { wetted } \\
\text { perimeter } \\
\text { vegetated }\end{array}$} & \multirow[b]{2}{*}{$\begin{array}{c}\text { Manning's } \\
n\end{array}$} \\
\hline & $\begin{array}{l}\text { Area } \\
\left(\mathrm{ft}^{2}\right)\end{array}$ & $\begin{array}{l}\text { Width } \\
\text { (ft) }\end{array}$ & $\begin{array}{l}\text { Hydraulic } \\
\text { radius } \\
\text { (ft) }\end{array}$ & $\begin{array}{l}\text { Velocity } \\
\text { (It/s) }\end{array}$ & $\begin{array}{l}\text { Froude } \\
\text { number }\end{array}$ & & & & \\
\hline$* 875$ & 201 & 76.2 & 2.53 & 4.80 & 0.55 & 0.00713 & 0.00603 & 7.7 & 0.043 \\
\hline 966 & 213 & 77.3 & 2.64 & 4.99 & .56 & .00739 & .00619 & 9.1 & .043 \\
\hline$* 1,050$ & 220 & 77.9 & 2.70 & 5.22 & .58 & .00725 & .00600 & 9.8 & .041 \\
\hline 1,060 & 223 & 78.8 & 2.72 & 5.17 & .57 & .00754 & .00613 & 10.8 & .043 \\
\hline 1,100 & 222 & 78.6 & 2.71 & 5.45 & .60 & .00780 & .00620 & 10.6 & .041 \\
\hline 1,190 & 242 & 81.3 & 2.80 & 5.34 & .57 & .00794 & .00626 & 15.6 & .044 \\
\hline$* 1,290$ & 252 & 81.6 & 2.95 & 5.58 & .59 & .00806 & .00637 & 11.8 & .043 \\
\hline 1,420 & 264 & 85.1 & 2.97 & 5.86 & .62 & .00832 & .00631 & 17.5 & .041 \\
\hline 1,450 & 272 & 86.4 & 3.02 & 5.84 & .61 & .00875 & .00651 & 18.7 & .043 \\
\hline$\S 1,560$ & 293 & 88.5 & 3.18 & 5.77 & .59 & .00855 & .00644 & 20.7 & .046 \\
\hline$* \$ 1,610$ & 299 & 88.9 & 3.22 & 5.89 & .60 & .00893 & .00663 & 21.1 & .046 \\
\hline$* \S 1,620$ & 296 & 88.7 & 3.20 & 5.95 & .60 & .00870 & .00642 & 20.9 & .044 \\
\hline$\$ 1,660$ & 303 & 89.6 & 3.24 & 6.02 & .61 & .00913 & .00658 & 21.7 & .045 \\
\hline 1,680 & 297 & 88.4 & 3.22 & 6.18 & .63 & .00899 & .00652 & 20.7 & .043 \\
\hline$* \$ 1,750$ & 314 & 91.7 & 3.32 & 6.07 & .64 & .00899 & .00656 & 22.9 & .045 \\
\hline$\S 1,780$ & 316 & 91.9 & 3.33 & 6.15 & .65 & .00913 & .00656 & 23.1 & .045 \\
\hline$\S 1,880$ & 323 & 92.5 & 3.38 & 6.39 & .67 & .00945 & .00662 & 23.6 & .044 \\
\hline
\end{tabular}

* The data used for this $\mathrm{n}$-value calculation were collected during the growing season.

$\S$ The $n$ values computed for each subreach differ by 0.011 to 0.017 . 


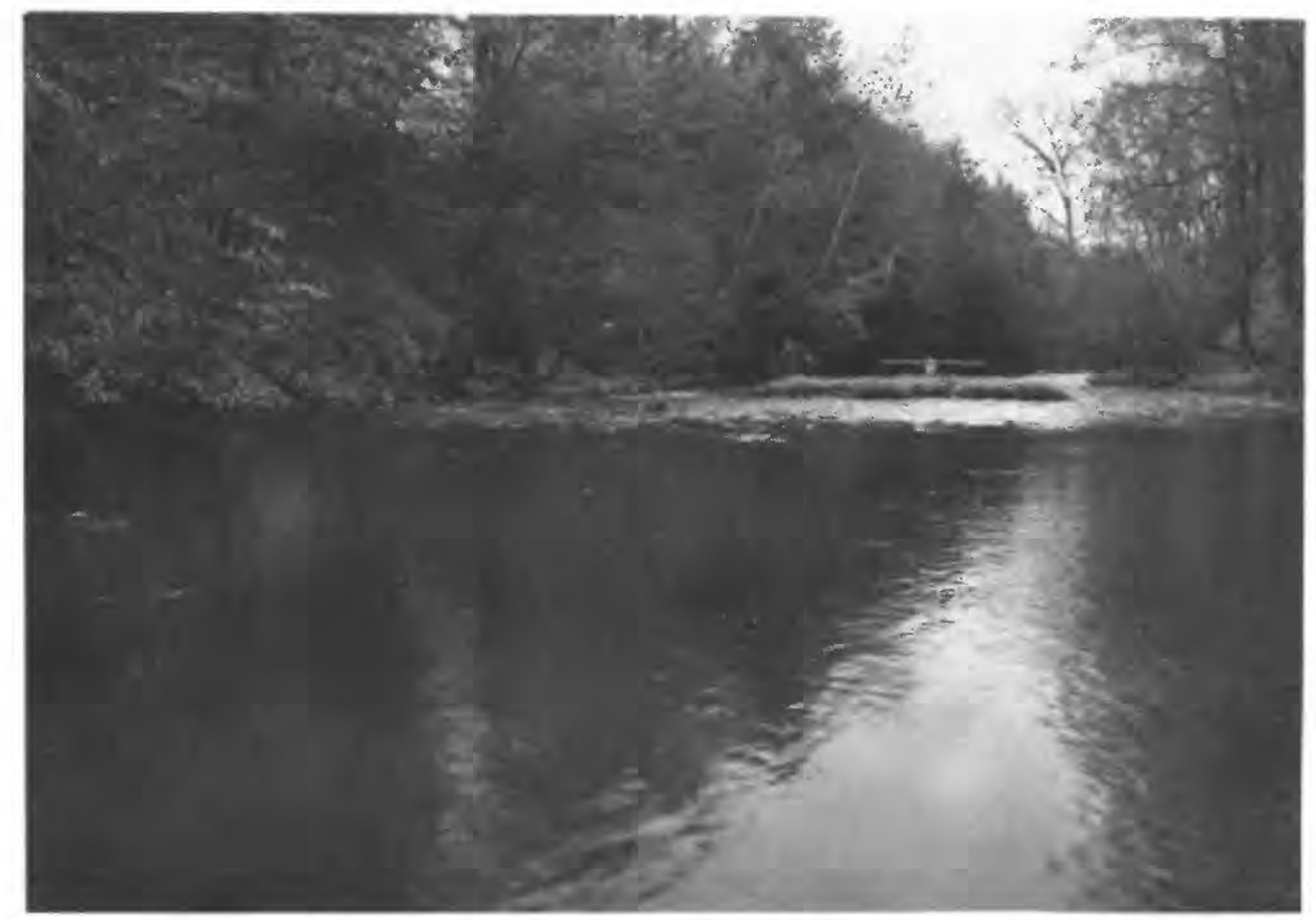

View from cross section 1, facing downstream.

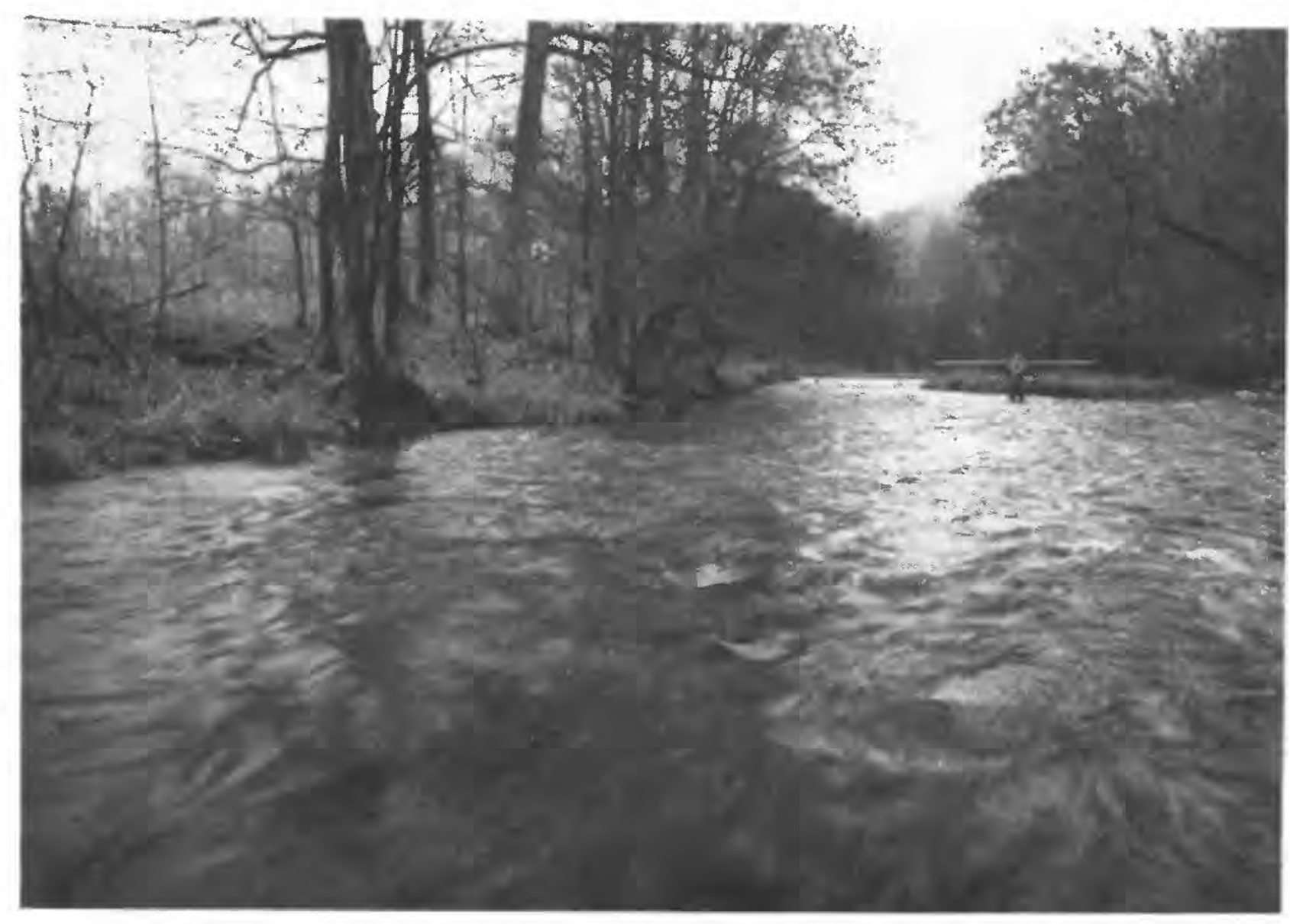

View from below cross section 3 , facing upstream toward right bank.

Figure A2-15. Ouleout Creek at East Sidney, N.Y. A. Photographs duning late fall. Hydrographer is at section 2 holding a 15-foot rod at approximate water-surface elevation of maximum recorded discharge. 

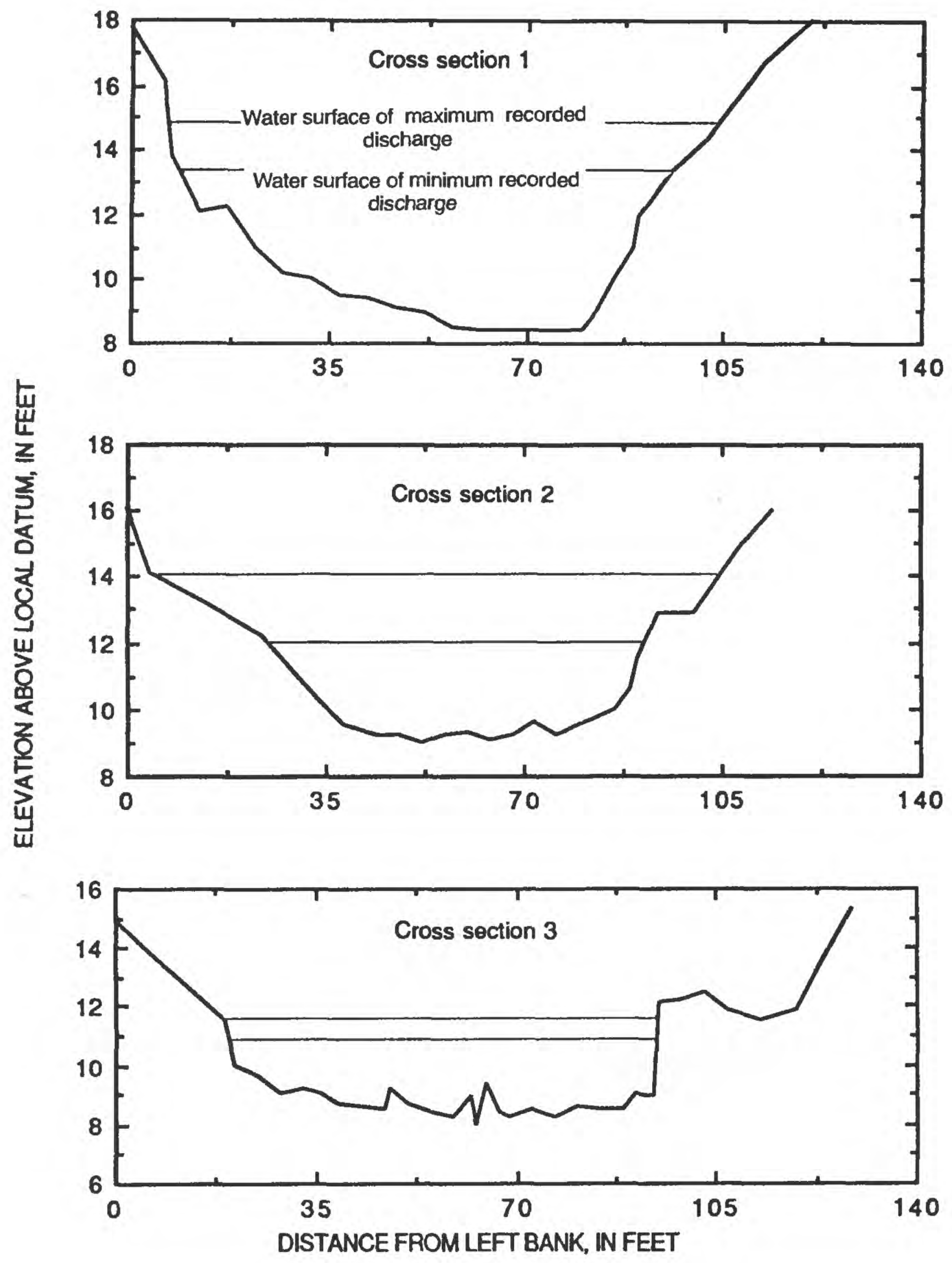

Figure A2-15. Ouleout Creek at East Sidney, N.Y. (continued). B. Cross sections. (Locations are shown in plan view on p. 103.) 


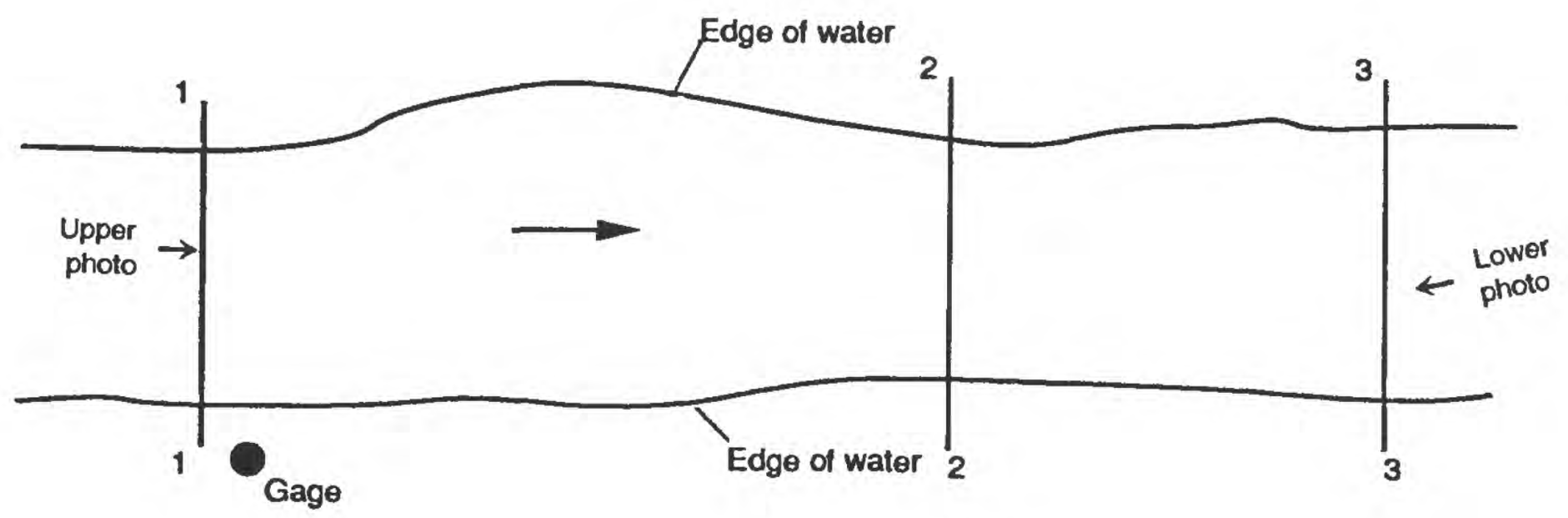

EXPLANATION
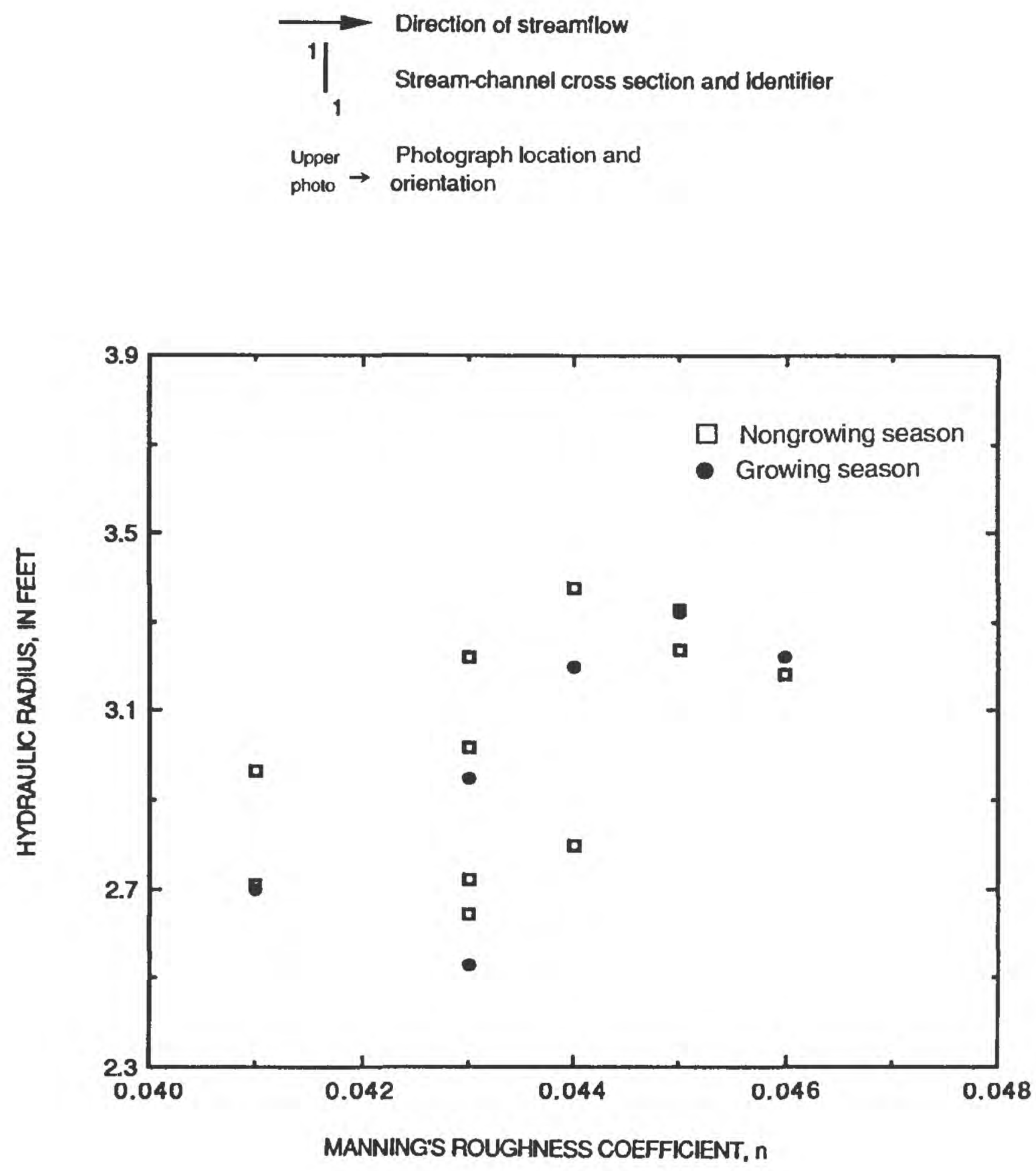

Figure A2-15. Ouleout Creek at East Sidney, N.Y. (continued). C. Plan view and relation between hydraulic radius and Manning's roughness coefficient duning growing and nongrowing seasons. 


\section{SITE 16. SUSQUEHANNA RIVER AT UNADILLA, N.Y.}

Table A2-16. Station description and hydraulic data

Location.--Latitude $42^{\circ} 19^{\prime} 17^{\prime \prime}$, longitude $75^{\circ} 19^{\prime} 01^{\prime \prime}$, Otsego County, on right bank $25 \mathrm{ft}$ downstream from bridge on Bridge Street at Unadilla, $1.0 \mathrm{mi}$ upstream from Carrs Creek, and $1.6 \mathrm{mi}$ downstream from Oulcout Creek. A 2-section, 430-ft-long reach; section 1 is at the gage.

USGS station-identification number.--01500500.

Drainage area.--982 $\mathrm{mi}^{2}$.

Bed material.--Cobbles, mostly flat. Intermediate diameter $\mathrm{d}_{50}=0.42 \mathrm{ft}$ and $\mathrm{d}_{84}=0.74 \mathrm{ft}$. Minimum diameter $\mathrm{d}_{50}=0.20 \mathrm{ft}$.

Bank description.--Both banks are steep and sparsely vegetated with brush and mature trees, 1.0 to 2.5 $\mathrm{ft}$ in diameter. Trees are spaced 20 to $50 \mathrm{ft}$ apart on the left bank and 50 to $100 \mathrm{ft}$ apart on right bank. Vegetation indices: $1,2$.

Remarks.--The velocity-head coefficients computed from discharge measurements made at this site range from 1.05 to 1.14 for discharges between 3,000 and $18,000 \mathrm{ft}^{3} / \mathrm{s}$.

\section{Hydraulic Data}

$\left[\mathrm{ft}=\mathrm{feet} ; \mathrm{ft}^{2}=\right.$ square feet; $\mathrm{ft} / \mathrm{s}=$ feet per second; $\mathrm{ft}^{3} / \mathrm{s}=$ cubic feet per second. $]$

\begin{tabular}{|c|c|c|c|c|c|c|c|c|c|}
\hline \multirow[b]{2}{*}{$\begin{array}{c}\text { Discharge } \\
\left(\mathrm{ft}^{3} / \mathrm{s}\right)\end{array}$} & \multicolumn{5}{|c|}{ Average values for reach } & \multirow[b]{2}{*}{$\begin{array}{l}\text { Water- } \\
\text { surface } \\
\text { slope }\end{array}$} & \multirow[b]{2}{*}{$\begin{array}{c}\text { Energy } \\
\text { gradient }\end{array}$} & \multirow[b]{2}{*}{$\begin{array}{c}\text { Percent } \\
\text { wetted } \\
\text { perimeter } \\
\text { vegetated }\end{array}$} & \multirow[b]{2}{*}{$\begin{array}{c}\text { Manning's } \\
\text { n }\end{array}$} \\
\hline & $\begin{array}{l}\text { Arca } \\
\left(\mathrm{ft}^{2}\right)\end{array}$ & $\begin{array}{l}\text { Width } \\
\text { (ft) }\end{array}$ & $\begin{array}{l}\text { Hydraulic } \\
\text { radius } \\
\text { (ft) }\end{array}$ & $\begin{array}{c}\text { Velocity } \\
(\mathrm{ft} / \mathrm{s})\end{array}$ & $\begin{array}{l}\text { Froude } \\
\text { number }\end{array}$ & & & & \\
\hline 3,540 & 1,150 & 190 & 5.95 & 3.11 & 0.22 & 0.00053 & 0.00043 & 1.1 & 0.033 \\
\hline$* 3,720$ & 1,170 & 190 & 6.06 & 3.20 & .23 & .00056 & .00045 & 1.6 & .033 \\
\hline 4,200 & 1,230 & 192 & 6.33 & 3.43 & .24 & .00058 & .00046 & 2.1 & .032 \\
\hline$* 4,210$ & 1,240 & 192 & 6.38 & 3.41 & .24 & .00074 & .00061 & 2.1 & .037 \\
\hline$* 4,320$ & 1,240 & 192 & 6.38 & 3.49 & .24 & .00067 & .00054 & 2.1 & .034 \\
\hline$* 4,450$ & 1,270 & 192 & 6.48 & 3.54 & .24 & .00053 & .00041 & 2.6 & .030 \\
\hline$* 5,880$ & 1,470 & 196 & 7.36 & 4.02 & .26 & .00058 & .00043 & 4.5 & .029 \\
\hline 6,160 & 1,470 & 196 & 7.36 & 4.22 & .27 & .00072 & .00054 & 5.0 & .031 \\
\hline 6,870 & 1,570 & 197 & 7.80 & 4.40 & .28 & .00077 & .00057 & 5.0 & .032 \\
\hline 9,100 & 1,770 & 202 & 8.63 & 5.16 & .31 & .00091 & .00065 & 7.8 & .031 \\
\hline 10,400 & 1,910 & 204 & 9.18 & 5.46 & .31 & .00105 & .00076 & 8.7 & .033 \\
\hline 14,300 & 2,220 & 210 & 10.28 & 6.48 & .35 & .00142 & .00100 & 11.6 & .034 \\
\hline 19,000 & 2,590 & 218 & 11.50 & 7.38 & .38 & .00151 & .00100 & 15.2 & .032 \\
\hline
\end{tabular}

* The data used for this n-value calculation were collected during the growing season. 


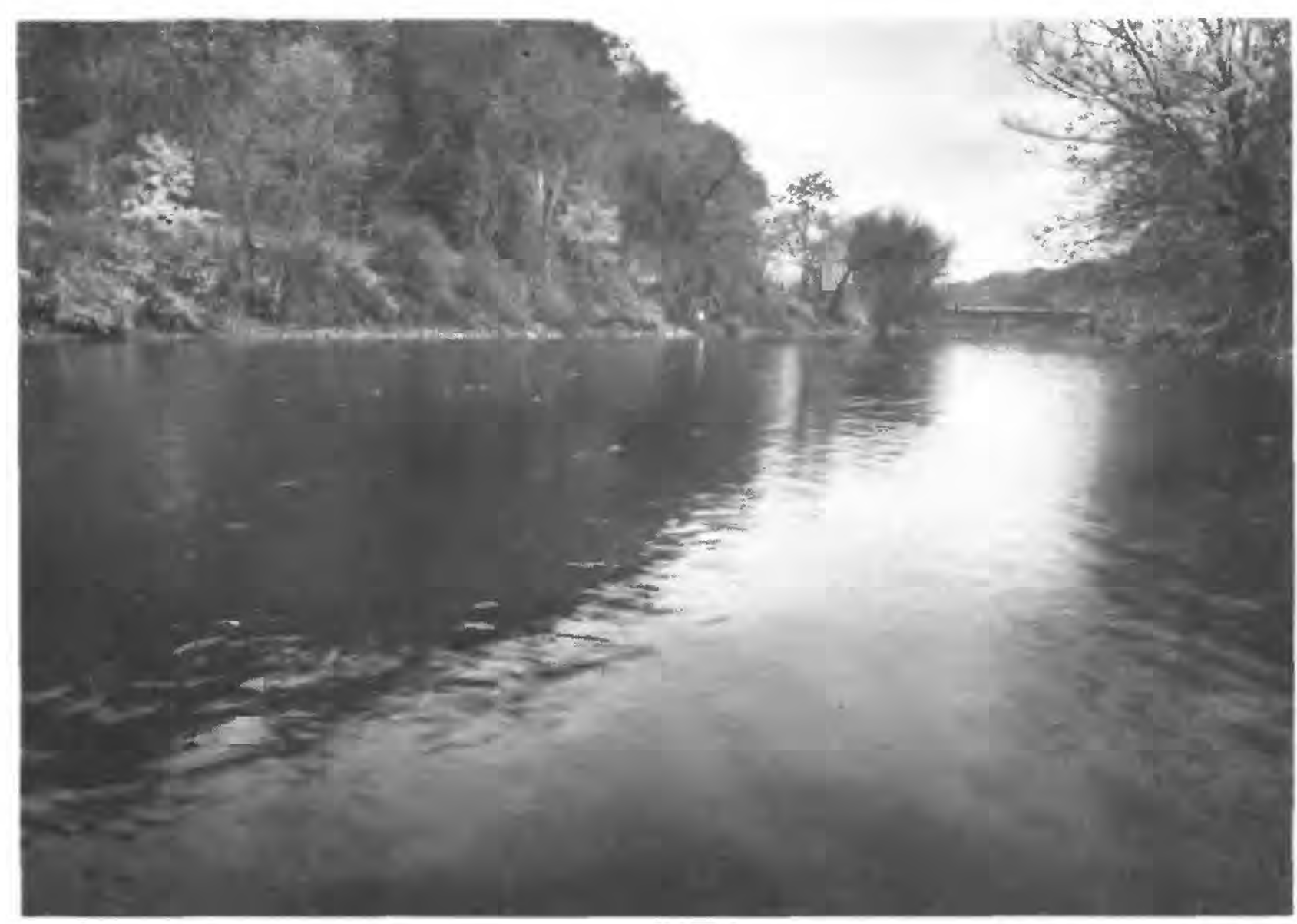

View from cross section 1, facing downstream toward left bank. Hydrographer is at section 2 holding cross-section-identification card (white square at left edge of water near center of photo).

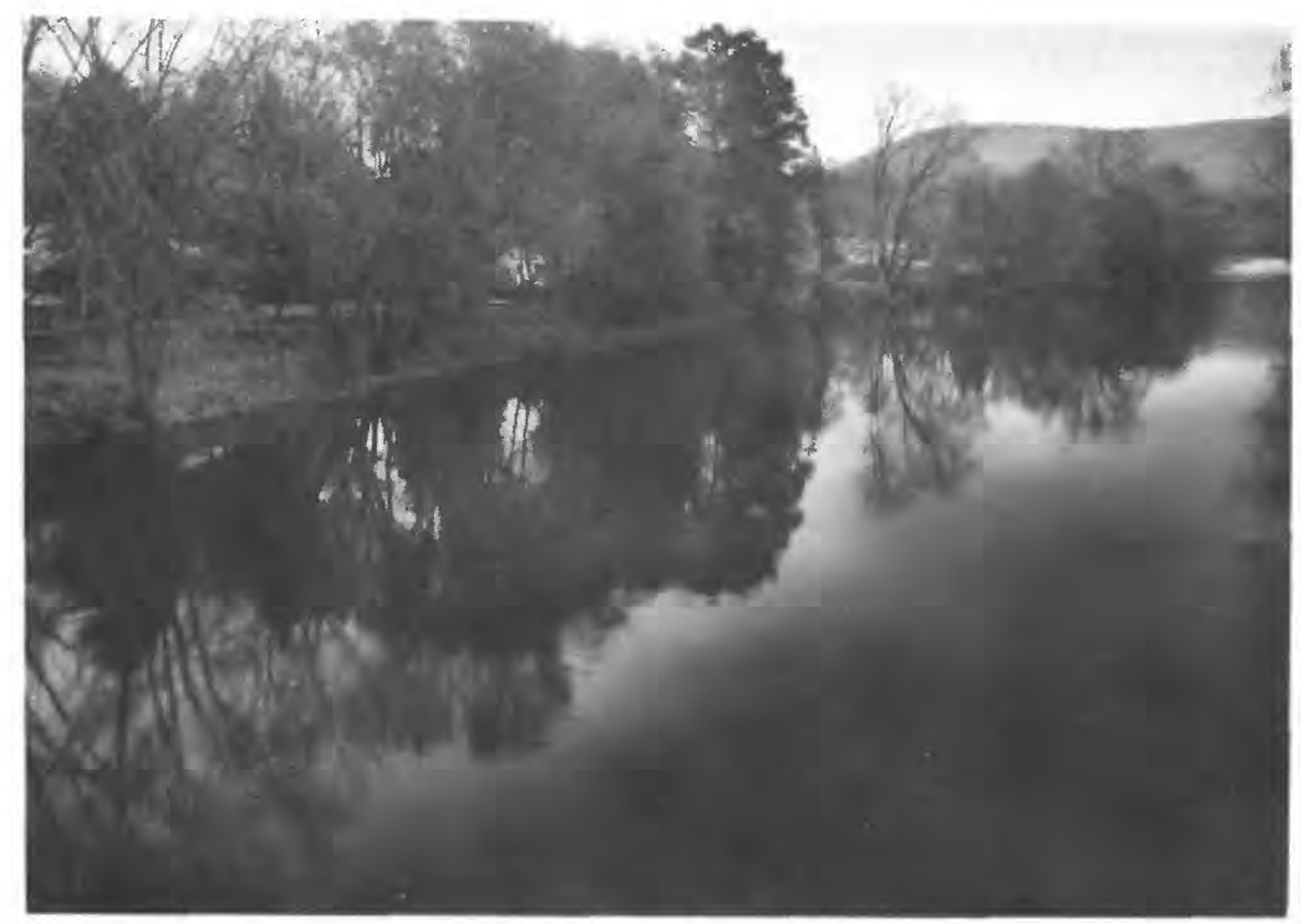

View from below cross section 2, facing upstream toward right bank.

Figure A2-16. Susquehanna River at Unadilla, N.Y. A. Photographs during late fall. 


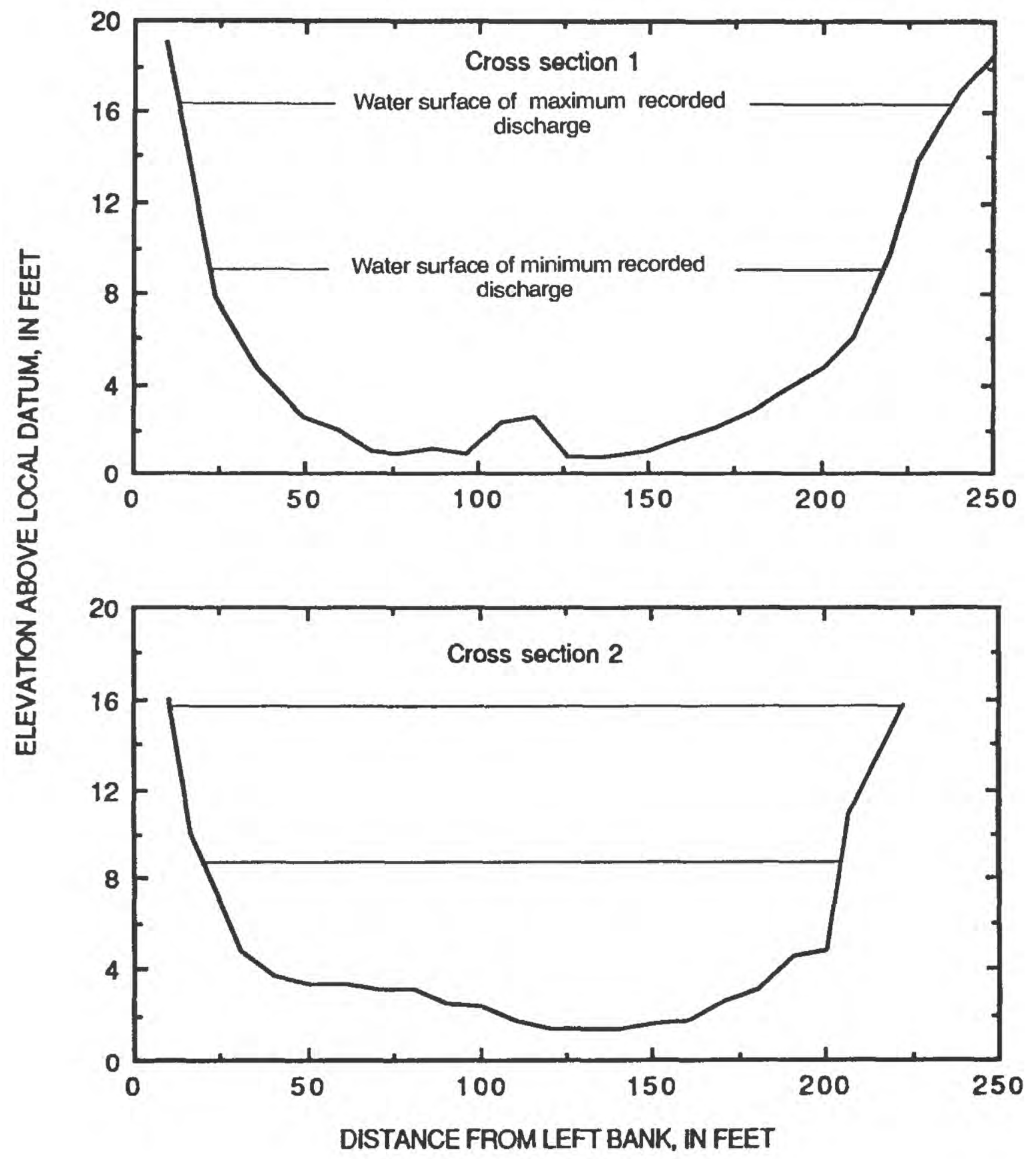

Figure A2-16. Susquehanna River at Unadilla, N.Y. (continued).

B. Cross sections. (Locations are shown in plan view on p. 107.) 
PLAN VIEW (not to scale)

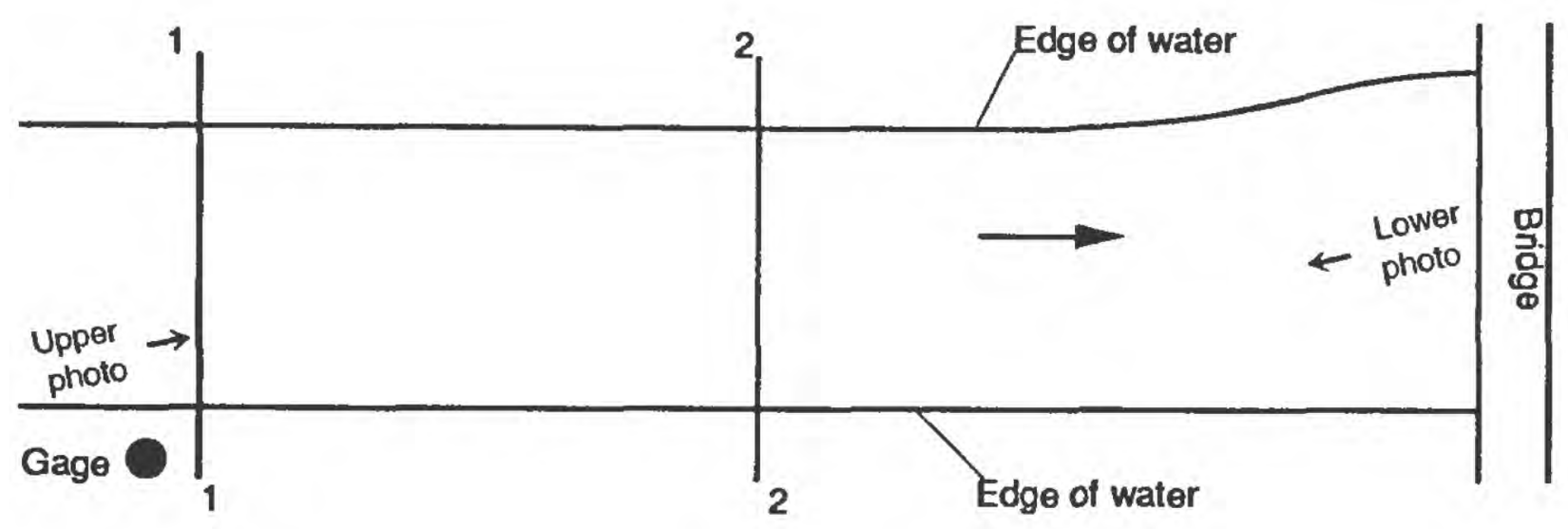

EXPLANATION
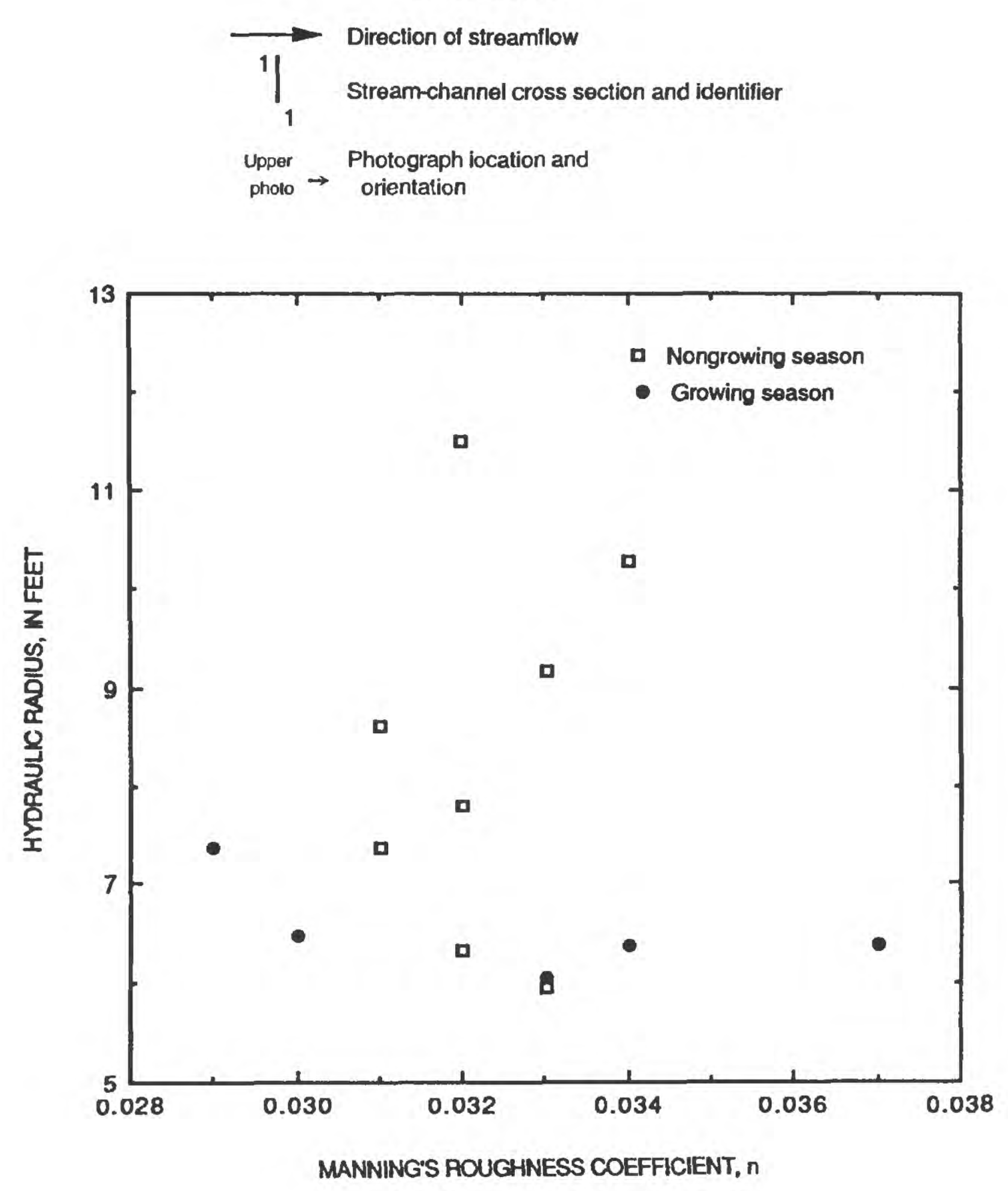

Figure A2-16. Susquehanna River at Unadilla, N.Y. (continued). C. Plan view and relation between hydraulic radius and Manning's roughness coefficient during growing and nongrowing seasons. 


\section{SITE 17. UNADILLA RIVER AT ROCKDALE, N.Y.}

Table A2-17. Station description and hydraulic data

Location.--Latitude $42^{\circ} 22^{\prime} 40^{\prime \prime}$, longitude $75^{\circ} 24^{\prime} 23^{\prime \prime}$, Chenango County, on right bank $400 \mathrm{ft}$ downstream from Chenango-Otsego County highway bridge at Rockdale, 0.7 mi downstream from Kent Brook. A 3-section, 559-ft-long reach is $0.8 \mathrm{mi}$ downstream from bridge in Rockdale.

USGS station-identification number.--01502500.

Drainage area. $-520 \mathrm{mi}^{2}$.

Bed material.--Cobbles, mostly flat. Intermediate diameter $\mathrm{d}_{50}=0.35 \mathrm{ft}$ and $\mathrm{d}_{84}=0.55 \mathrm{ft}$. Minimum diameter $\mathrm{d}_{50}=0.11 \mathrm{ft}$.

Bank description.--Both banks are steep and densely vegetated with brush, vines, and trees. Tree density on right bank is 1 tree about every $10 \mathrm{ft}$. Vegetation indices: 3,4 .

\section{Hydraulic Data}

$\left[\mathrm{ft}=\mathrm{feet} ; \mathrm{ft}^{2}=\right.$ square feet; $\mathrm{ft} / \mathrm{s}=$ feet per second; $\mathrm{ft}^{3} / \mathrm{s}=$ cubic feet per second. $]$

\begin{tabular}{|c|c|c|c|c|c|c|c|c|c|}
\hline \multirow[b]{2}{*}{$\begin{array}{c}\text { Discharge } \\
\left(\mathrm{ft}^{3} / \mathrm{s}\right)\end{array}$} & \multicolumn{5}{|c|}{ Average values for reach } & \multirow[b]{2}{*}{$\begin{array}{l}\text { Water- } \\
\text { surface } \\
\text { slope }\end{array}$} & \multirow[b]{2}{*}{$\begin{array}{l}\text { Energy } \\
\text { gradient }\end{array}$} & \multirow[b]{2}{*}{$\begin{array}{c}\text { Percent } \\
\text { wetted } \\
\text { perimeter } \\
\text { vegetated }\end{array}$} & \multirow[b]{2}{*}{$\begin{array}{c}\text { Manning's } \\
n\end{array}$} \\
\hline & $\begin{array}{l}\text { Area } \\
\left(\mathrm{ft}^{2}\right)\end{array}$ & $\begin{array}{l}\text { Width } \\
\text { (ft) }\end{array}$ & $\begin{array}{c}\text { Hydraulic } \\
\text { radius } \\
(\mathrm{ft})\end{array}$ & $\begin{array}{c}\text { Velocity } \\
(\mathrm{ft} / \mathrm{s})\end{array}$ & $\begin{array}{l}\text { Froude } \\
\text { number }\end{array}$ & & & & \\
\hline 1,430 & 501 & 148 & 3.45 & 2.90 & 0.28 & 0.00109 & 0.00096 & 0.7 & 0.034 \\
\hline 1,650 & 530 & 148 & 3.63 & 3.15 & .30 & .00106 & .00092 & .7 & .032 \\
\hline 1,800 & 566 & 148 & 3.85 & 3.21 & .29 & .00097 & .00085 & 1.3 & .032 \\
\hline$* 1,830$ & 578 & 149 & 3.92 & 3.19 & .29 & .00091 & .00081 & 1.3 & .031 \\
\hline 2,080 & 605 & 149 & 4.09 & 3.46 & .31 & .00106 & .00093 & 2.0 & .032 \\
\hline 2,240 & 632 & 150 & 4.24 & 3.56 & .31 & .00107 & .00095 & 2.0 & .032 \\
\hline 2,430 & 648 & 150 & 4.34 & 3.77 & .32 & .00104 & .00091 & 2.6 & .031 \\
\hline$* 2,600$ & 676 & 150 & 4.51 & 3.86 & .32 & .00098 & .00087 & 2.6 & .030 \\
\hline 2,870 & 710 & 151 & 4.70 & 4.06 & .33 & .00102 & .00091 & 3.2 & .030 \\
\hline$* 3,140$ & 762 & 151 & 4.99 & 4.13 & .33 & .00093 & .00084 & 3.9 & .030 \\
\hline$* 3,330$ & 783 & 152 & 5.13 & 4.26 & .33 & .00093 & .00085 & 5.7 & .029 \\
\hline 4,040 & 868 & 154 & 5.59 & 4.66 & .35 & .00091 & .00085 & 5.7 & .029 \\
\hline 4,150 & 892 & 155 & 5.72 & 4.66 & .34 & .00098 & .00092 & 5.7 & .030 \\
\hline 4,580 & 946 & 156 & 5.99 & 4.84 & .35 & .00088 & .00084 & 6.9 & .029 \\
\hline 4,660 & 941 & 156 & 5.97 & 4.95 & .36 & .00098 & .00093 & 6.9 & .030 \\
\hline$\ddagger 6,170$ & 1,150 & 157 & 7.11 & 5.38 & .35 & .00086 & .00088 & 8.6 & .030 \\
\hline$\ddagger 6,330$ & 1,160 & 157 & 7.15 & 5.48 & .36 & .00080 & .00083 & 8.6 & .029 \\
\hline$\$ 6,370$ & 1,200 & 158 & 7.36 & 5.33 & .34 & .00089 & .00092 & 9.1 & .032 \\
\hline$* \div 7,540$ & 1,290 & 159 & 7.88 & 5.83 & .36 & .00077 & .00082 & 10.2 & .029 \\
\hline$\$ 8,280$ & 1,360 & 159 & 8.23 & 6.09 & .37 & .00073 & .00080 & 10.8 & .028 \\
\hline$\ddagger 13,000$ & 1,700 & 162 & 9.94 & 7.67 & .42 & .00091 & .00106 & 13.4 & .029 \\
\hline
\end{tabular}

* The data used for this $\mathrm{n}$-value claculation were collected during the growing season.

$\ddagger$ The left-bank overflow area is treated as ineffective-flow area for this $n$-value calculation. The data reflect this modification to the cross section. The computed $n$ values are affected by 1 - to 9 -percent flow-area expansion 


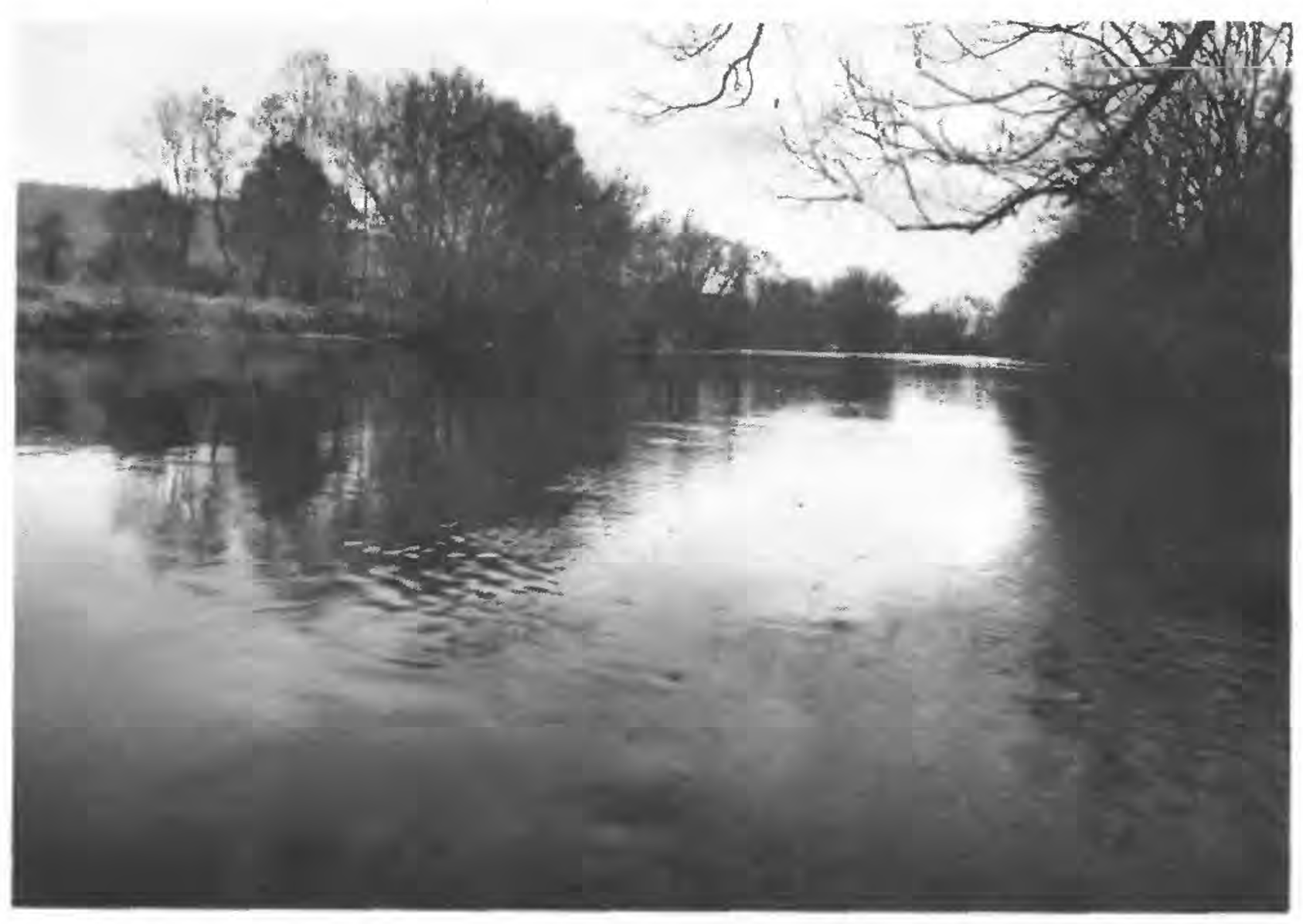

View from cross section 1, facing downstream toward left bank.

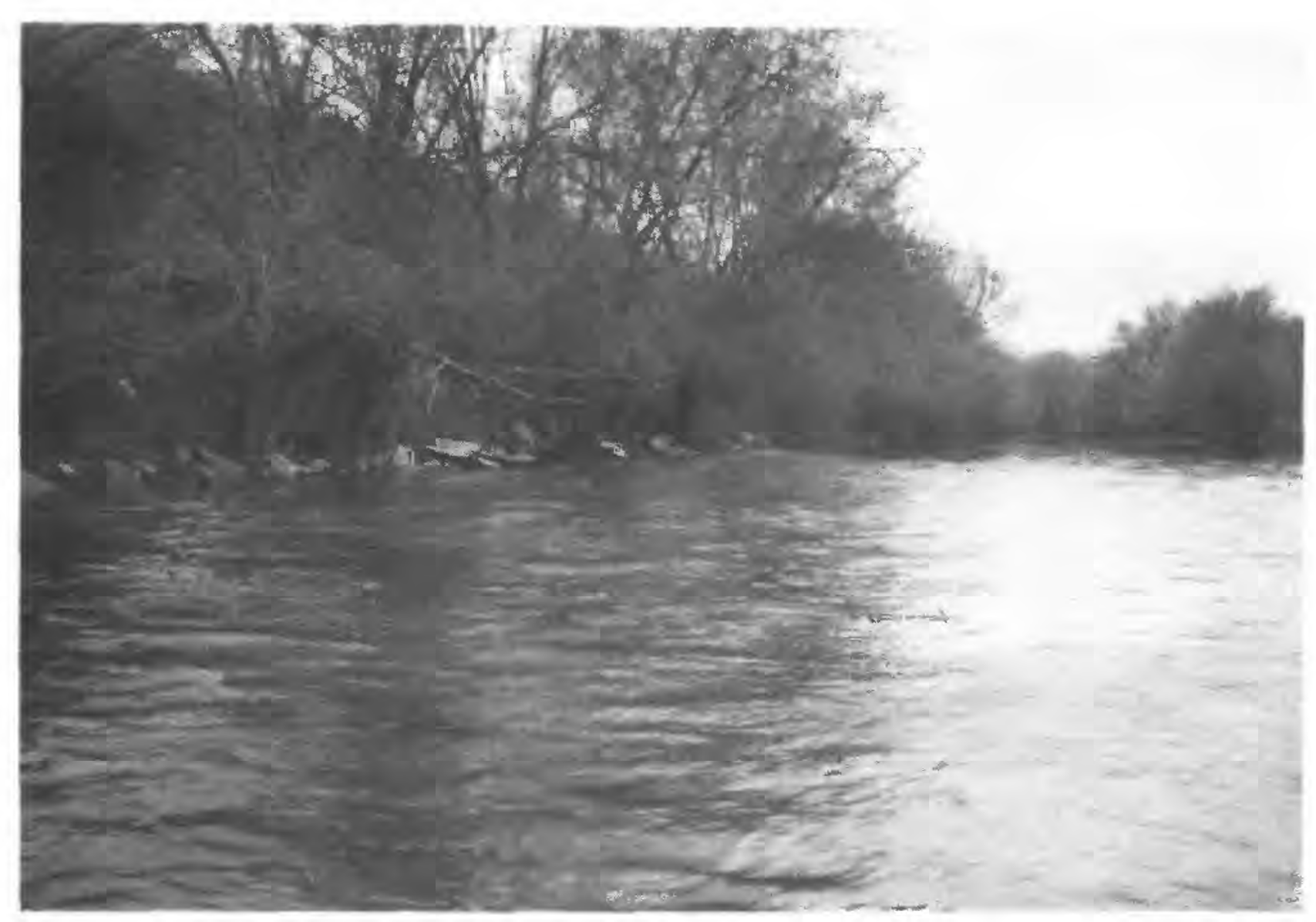

View from cross section 3, facing upstream along right bank.

Figure A2-17. Unadilla River at Rockdale, N.Y. A. Photographs during late fall. 

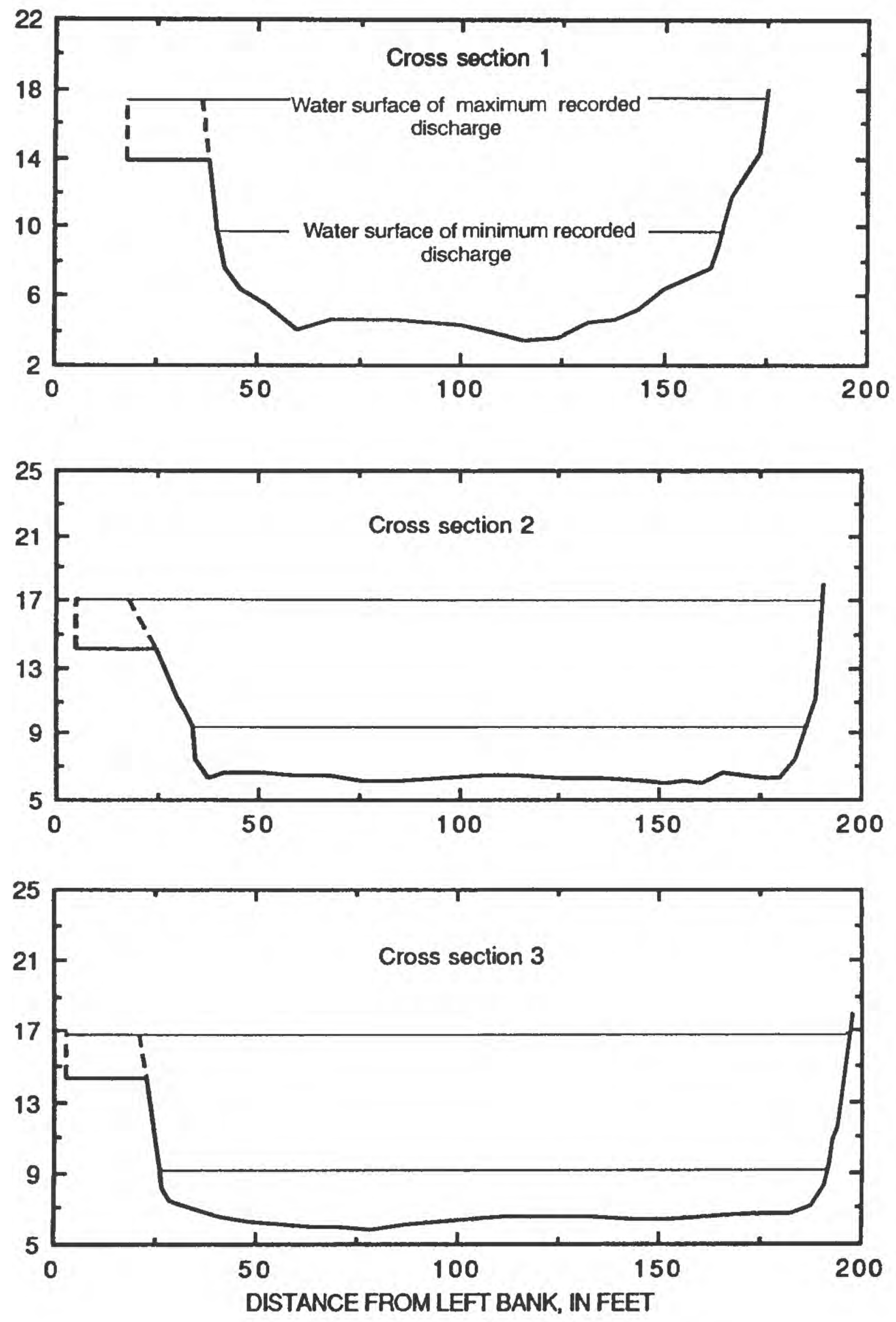

Figure A2-17. Unadilla River at Rockdale, N.Y. (continued). on p. 111.)

B. Cross sections. (Locations are shown in plan view 
PLAN VIEW (not to scale)

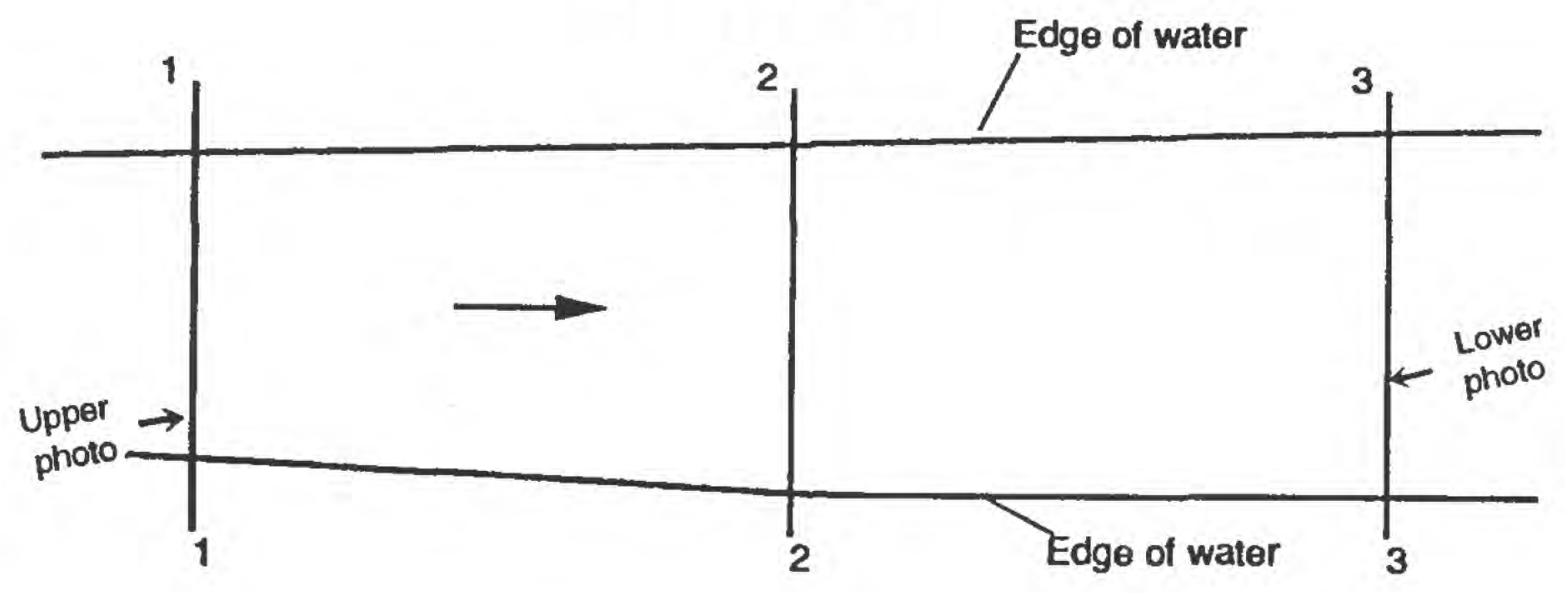

EXPLANATION
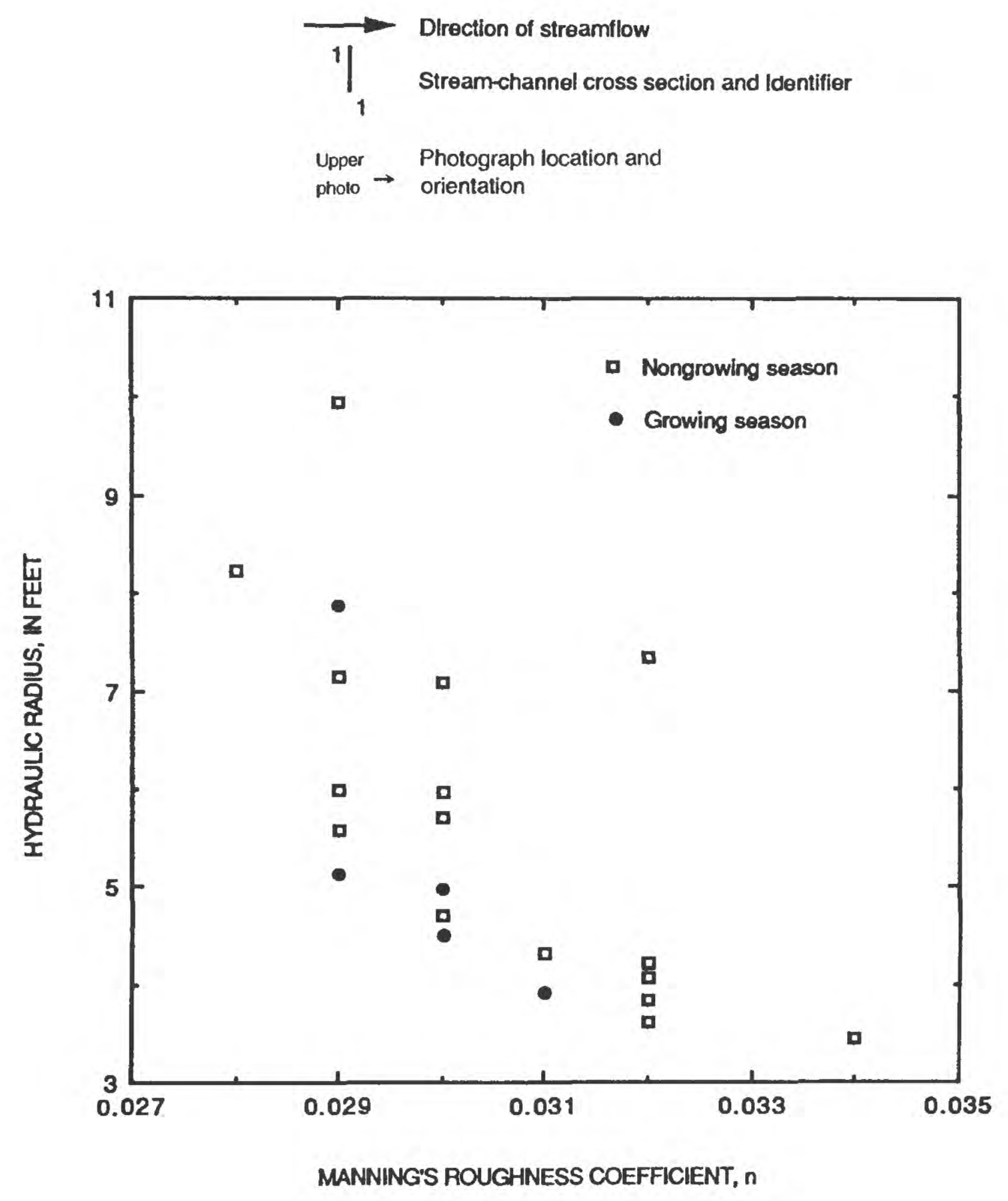

Flgure A2-17. Unadilla River at Rockdale, N.Y. (continued). C. Plan view and relation between hydraulic radius and Manning's roughness coefficient duning growing and nongrowing seasons. 


\section{SITE 18. TIOUGHNIOGA RIVER AT CORTLAND, N.Y.}

Table A2-18. Station description and hydraulic data

Location.--Latitude $42^{\circ} 36^{\prime} 10^{\prime \prime}$, longitude $76^{\circ} 09^{\prime} 35^{\prime \prime}$, Cortland County, on right bank at east end of Elm Street at Cortland, $0.4 \mathrm{mi}$ downstream from confluence of East and West Branches. A 3-section, 1,150-ft-long reach; section 1 is $450 \mathrm{ft}$ upstream from gage.

USGS station-identification number.--01509000.

Drainage area. $-292 \mathrm{mi}^{2}$.

Bed material.--Gravel and small cobbles. Intermediate diameter $\mathrm{d}_{50}=0.07 \mathrm{ft}$ and $\mathrm{d}_{84}=0.29 \mathrm{ft}$. Minimum diameter $\mathrm{d}_{50}=0.04 \mathrm{ft}$.

Bank description.--Left bank has dense brush and scattered trees 20 to $50 \mathrm{ft}$ apart. Right bank is grasslined and has a few small, bushy trees. Vegetation indices: $0.5,1.5$.

Remarks.--The $\mathrm{n}$ values computed for flows less than about $4,000 \mathrm{ft}^{3} / \mathrm{s}$ are affected by 10 - to 13 -percent flow-area expansion in the reach; those for higher flows are affected by 6- to 9-percent flow-area expansion.

\section{Hydraulic Data}

$\left[\mathrm{ft}=\right.$ feet; $\mathrm{ft}^{2}=$ square feet; $\mathrm{ft} / \mathrm{s}=$ feet per second; $\mathrm{ft}^{3} / \mathrm{s}=$ cubic feet per second. $]$

\begin{tabular}{|c|c|c|c|c|c|c|c|c|c|}
\hline \multirow[b]{2}{*}{$\begin{array}{c}\text { Discharge } \\
\left(\mathrm{ft}^{3} / \mathrm{s}\right)\end{array}$} & \multicolumn{5}{|c|}{ Average values for reach } & \multirow[b]{2}{*}{$\begin{array}{l}\text { Water- } \\
\text { surface } \\
\text { slope }\end{array}$} & \multirow[b]{2}{*}{$\begin{array}{l}\text { Energy } \\
\text { gradient }\end{array}$} & \multirow[b]{2}{*}{$\begin{array}{c}\text { Percent } \\
\text { wetted } \\
\text { perimeter } \\
\text { vegetated }\end{array}$} & \multirow[b]{2}{*}{$\begin{array}{c}\text { Manning's } \\
n\end{array}$} \\
\hline & $\begin{array}{l}\text { Area } \\
\left(\mathrm{ft}^{2}\right)\end{array}$ & $\begin{array}{l}\text { Widıh } \\
\text { (ft) }\end{array}$ & $\begin{array}{l}\text { Hydraulic } \\
\text { radius } \\
\text { (ft) }\end{array}$ & $\begin{array}{c}\text { Velocity } \\
(\mathrm{ft} / \mathrm{s})\end{array}$ & $\begin{array}{l}\text { Froude } \\
\text { number }\end{array}$ & & & & \\
\hline 1,390 & 580 & 185 & 3.11 & 2.40 & 0.24 & 0.00057 & 0.00059 & 0.5 & 0.032 \\
\hline 1,590 & 630 & 186 & 3.36 & 2.53 & .24 & .00057 & .00058 & 1.6 & .032 \\
\hline 1,680 & 649 & 187 & 3.45 & 2.60 & .25 & .00057 & .00058 & 1.6 & .032 \\
\hline$* 1,920$ & 706 & 188 & 3.72 & 2.73 & .25 & .00057 & .00059 & 2.6 & .032 \\
\hline 1,990 & 729 & 189 & 3.82 & 2.74 & .25 & .00052 & .00054 & 3.1 & .031 \\
\hline 2,290 & 794 & 190 & 4.12 & 2.89 & .25 & .00051 & .00052 & 3.6 & .030 \\
\hline 2,330 & 801 & 190 & 4.16 & 2.92 & .25 & .00053 & .00055 & 4.1 & .031 \\
\hline 2,750 & 890 & 193 & 4.55 & 3.10 & .25 & .00048 & .00049 & 5.1 & .029 \\
\hline 2,750 & 869 & 192 & 4.46 & 3.17 & .26 & .00051 & .00052 & 5.1 & .029 \\
\hline 2,810 & 904 & 193 & 4.61 & 3.12 & .25 & .00051 & .00052 & 5.6 & .030 \\
\hline 2,820 & 909 & 194 & 4.64 & 3.11 & .25 & .00048 & .00049 & 5.6 & .030 \\
\hline 3,590 & 1,060 & 198 & 5.29 & 3.39 & .26 & .00044 & .00046 & 8.0 & .029 \\
\hline 4,170 & 1,160 & 201 & 5.69 & 3.61 & .26 & .00046 & .00048 & 9.3 & .029 \\
\hline 4,320 & 1,180 & 201 & 5.79 & 3.65 & .27 & .00044 & .00045 & 9.8 & .028 \\
\hline 5,640 & 1,380 & 215 & 6.32 & 4.09 & .28 & .00055 & .00056 & 15.1 & .029 \\
\hline$\$ 8,900$ & 1,770 & 217 & 7.96 & 5.02 & .31 & .00048 & .00049 & 17.0 & .026 \\
\hline
\end{tabular}

$\ddagger$ The right-bank overflow area is treated as ineffective-flow area for this n-value calculation. The data reflect this modification to the cross sections.

* The data used for this n-value calculation were collected during the growing season. 


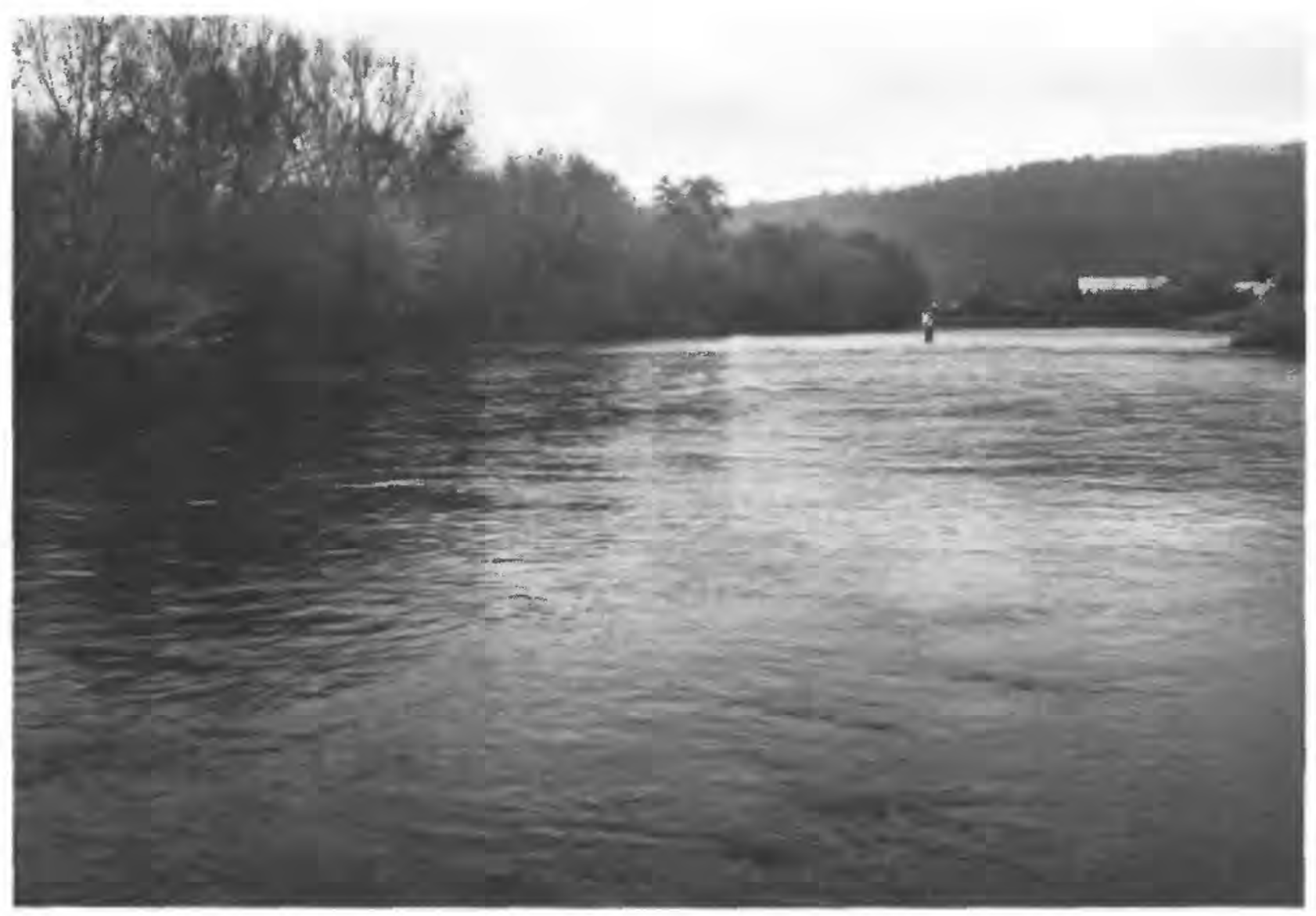

View from below cross section 1, facing downstream toward left bank.

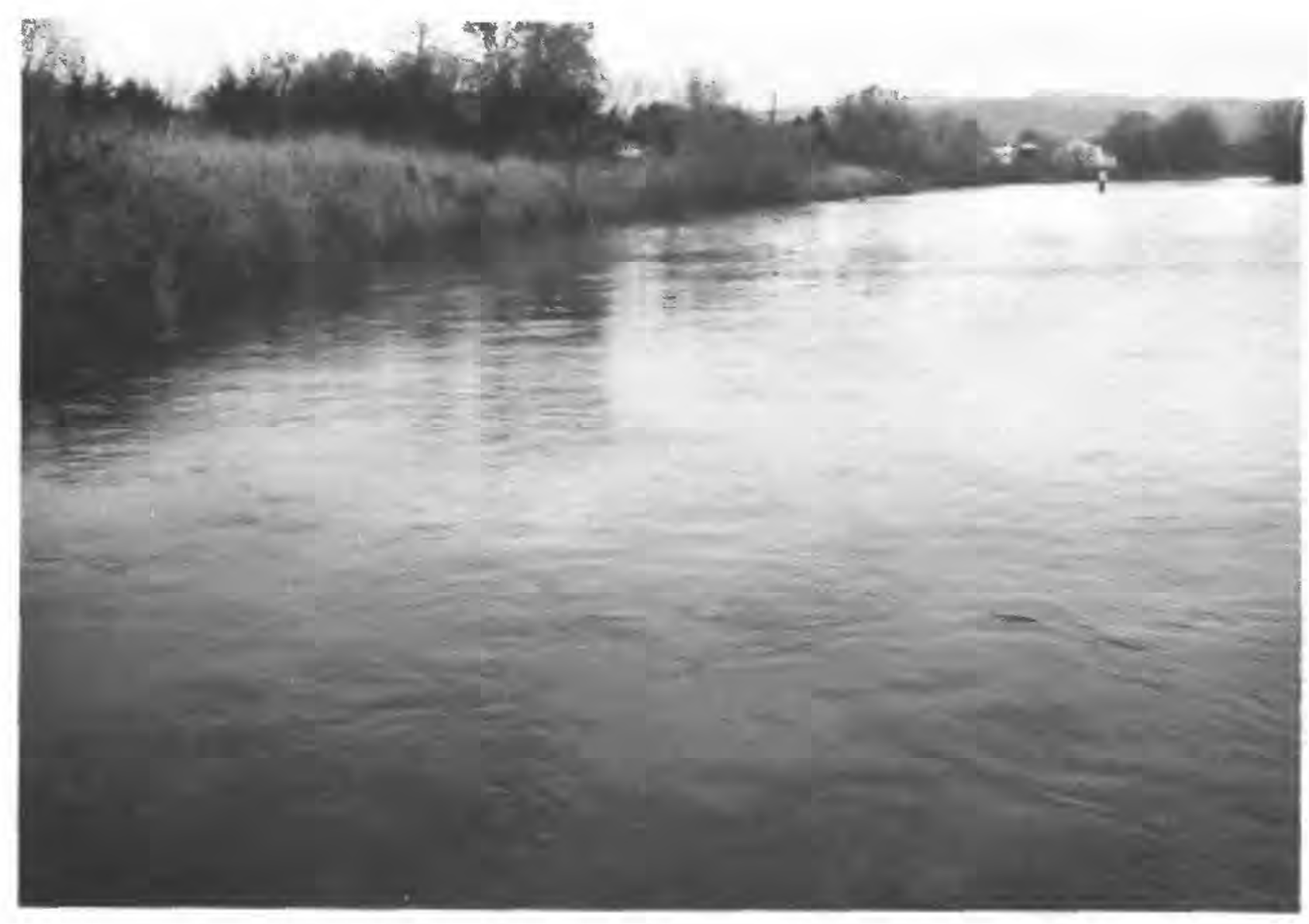

View from cross section 3, facing upstream toward right bank.

Figure A2-18. Tioughnioga River at Cortland, N.Y. A. Photographs during late fall. Hydrographer is at section 2. 

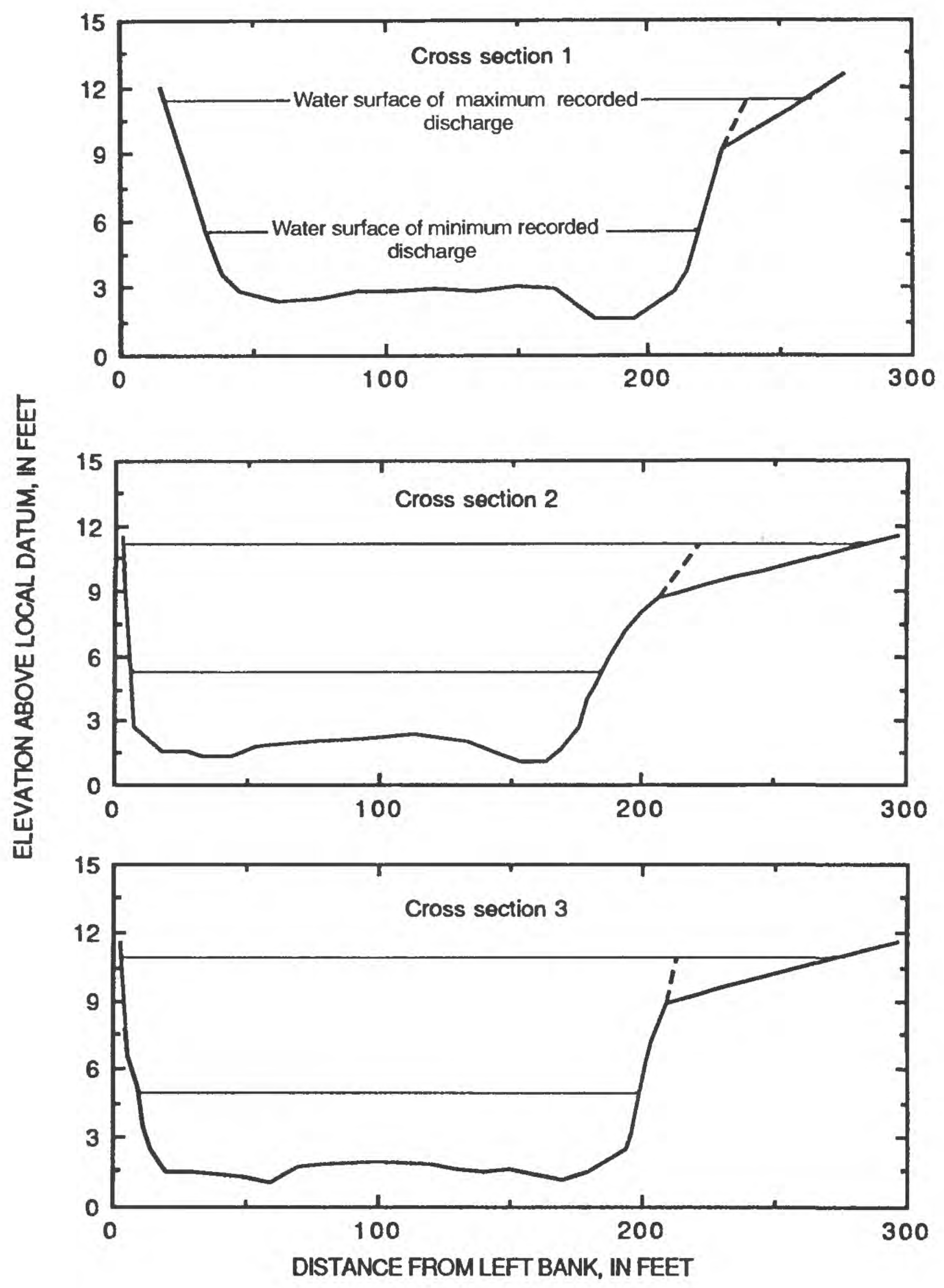

Flgure A2-18. Tioughnioga River at Cortland, N.Y. (continued). B. Cross sections. (Locations are shown in plan view on p. 115.) 


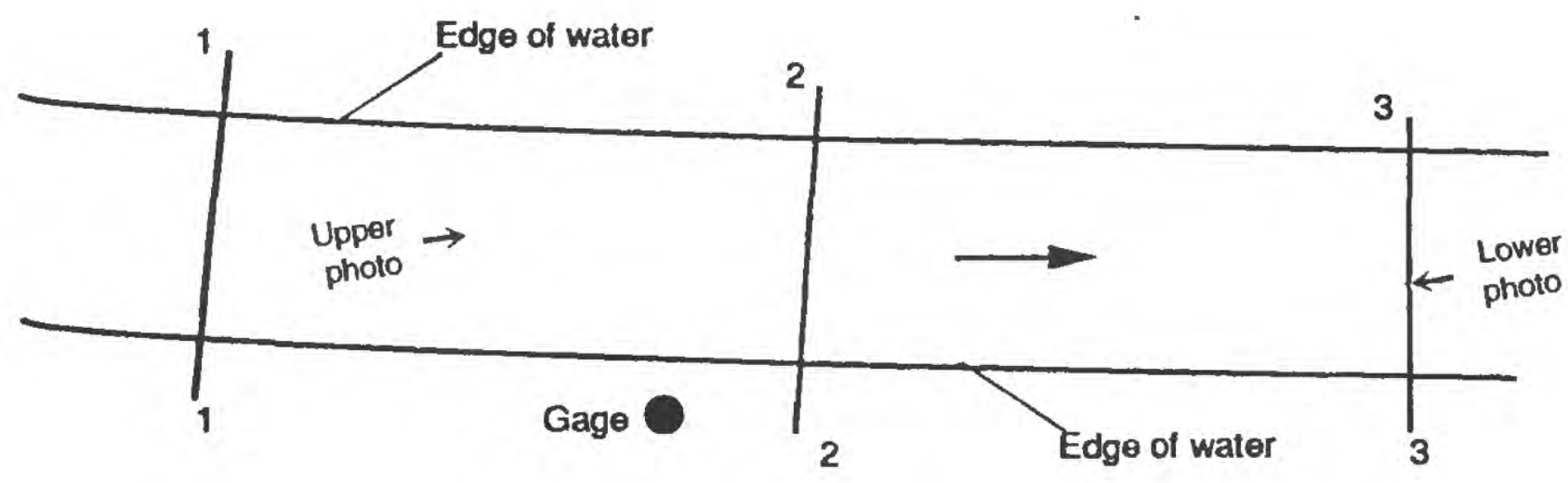

EXPLANATION
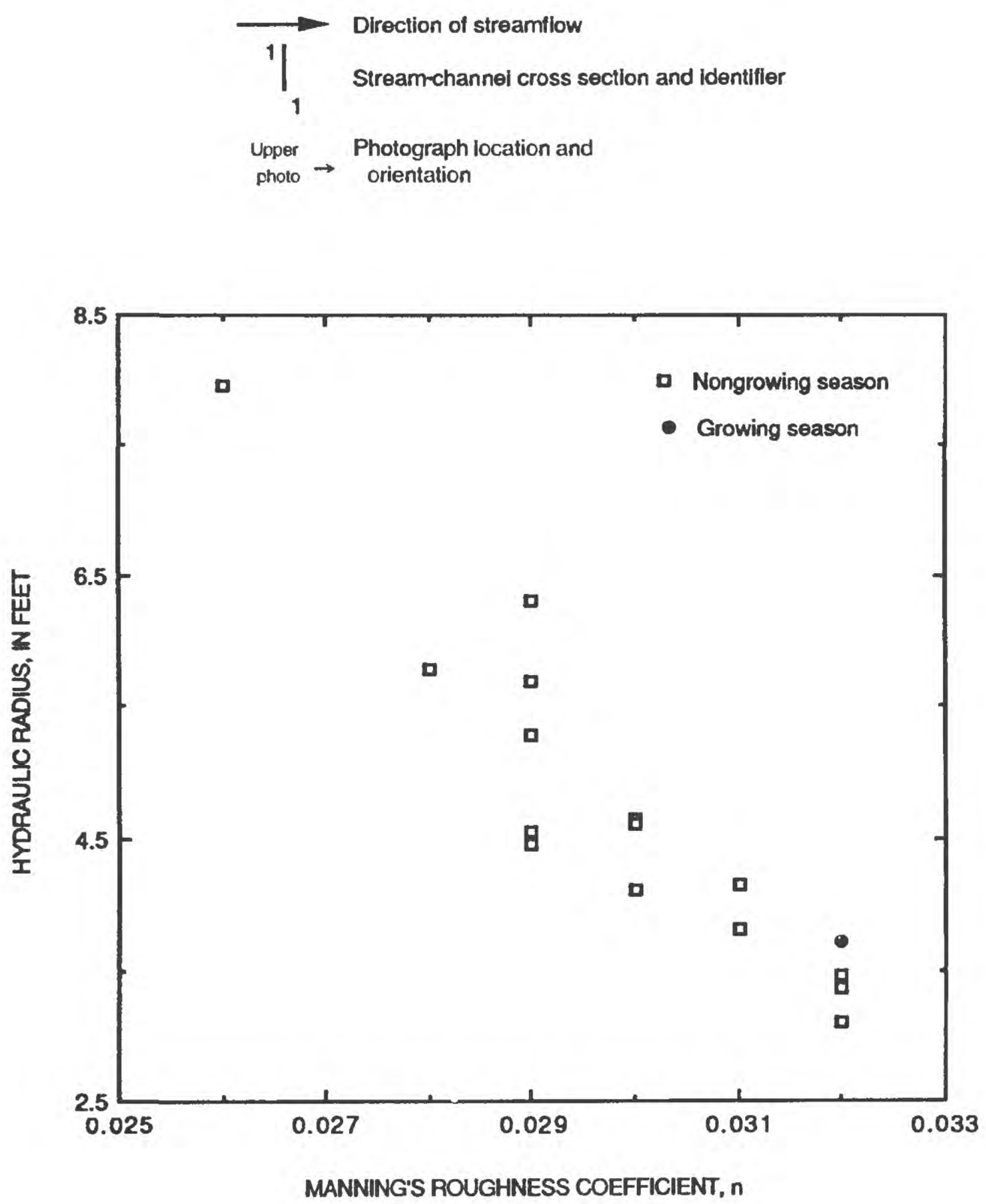

Figure A2-18. Tioughnioga River at Cortland, N.Y. (continued). C. Plan view and relation between hydraulic radius and Manning's roughness coefficient during growing and nongrowing seasons. 


\section{SITE 19. CHENANGO RIVER NEAR CHENANGO FORKS, N.Y.}

Table A2-19. Station description and hydraulic data

Location.--Latitude $42^{\circ} 13^{\prime} 05^{\prime \prime}$, longitude $75^{\circ} 50^{\prime} 55^{\prime \prime}$, Broome County, on left bank in Chenango Valley State Park, and $1.2 \mathrm{mi}$ downstream from Tioughnioga River and village of Chenango Forks. A 3section, 1,340-ft-long reach; section 1 is $650 \mathrm{ft}$ upstream from gage.

USGS station-identification number.--01512500.

Drainage area.--1,483 $\mathrm{mi}^{2}$.

Bed material.--Cobbles, mostly flat. Intermediate diameter $\mathrm{d}_{50}=0.37$ and $\mathrm{d}_{84}=0.60 \mathrm{ft}$. Minimum diameter $\mathrm{d}_{50}=0.18 \mathrm{ft}$.

Bank description.--Both banks are steep, and lower parts are vegetated with grass, annual weeds, woody brush, and a few scattered trees. Upper parts have trees, 0.5 to $2.0 \mathrm{ft}$ in diameter and spaced about $10 \mathrm{ft}$ apart. Vegetation indices: 1,2.

Remarks.--Floodflows are partly regulated by Whitney Point Lake. The velocity-head coefficients computed from discharge measurements made at this site range from 1.04 to 1.12 for discharges between 5,000 and $24,000 \mathrm{ft}^{3} / \mathrm{s}$.

\section{Hydraulic Data}

$\left[\mathrm{ft}=\mathrm{feet} ; \mathrm{ft}^{2}=\right.$ square feet; $\mathrm{ft} / \mathrm{s}=$ feet per second; $\mathrm{ft}^{3} / \mathrm{s}=$ cubic feet per second. $]$

\begin{tabular}{|c|c|c|c|c|c|c|c|c|c|}
\hline \multirow[b]{2}{*}{$\begin{array}{c}\text { Discharge } \\
\left(\mathrm{ft}^{3} / \mathrm{s}\right)\end{array}$} & \multicolumn{5}{|c|}{ Average values for reach } & \multirow[b]{2}{*}{$\begin{array}{l}\text { Water- } \\
\text { surface } \\
\text { slope }\end{array}$} & \multirow[b]{2}{*}{$\begin{array}{c}\text { Energy } \\
\text { gradient }\end{array}$} & \multirow{2}{*}{$\begin{array}{c}\text { Percent } \\
\text { wetted } \\
\text { perimeter } \\
\text { vegetated }\end{array}$} & \multirow[b]{2}{*}{$\underset{n}{\text { Manning's }}$} \\
\hline & $\begin{array}{l}\text { Arca } \\
\left(\mathrm{ft}^{2}\right)\end{array}$ & $\begin{array}{l}\text { Width } \\
(\mathrm{ft})\end{array}$ & $\begin{array}{l}\text { Hydraulic } \\
\text { radius } \\
\text { (ft) }\end{array}$ & $\begin{array}{c}\text { Velocity } \\
\text { (ft/s) }\end{array}$ & $\begin{array}{l}\text { Froude } \\
\text { number }\end{array}$ & & & & \\
\hline 5,280 & 1,640 & 385 & 4.27 & 3.22 & 0.28 & 0.00073 & 0.00072 & 1.6 & 0.032 \\
\hline$* 5,800$ & 1,730 & 386 & 4.48 & 3.36 & .28 & .00078 & .00077 & 2.1 & .032 \\
\hline 6,430 & 1,810 & 388 & 4.66 & 3.56 & .29 & .00081 & .00079 & 2.6 & .032 \\
\hline 6,620 & 1,830 & 389 & 4.71 & 3.62 & .29 & .00081 & .00079 & 2.6 & .032 \\
\hline 7,410 & 1,950 & 391 & 4.98 & 3.81 & .30 & .00086 & .00083 & 3.3 & .032 \\
\hline$* 7,520$ & 1,960 & 391 & 4.99 & 3.85 & .30 & .00089 & .00087 & 3.3 & .032 \\
\hline$* 8,180$ & 2,050 & 394 & 5.20 & 3.99 & .31 & .00089 & .00087 & 3.8 & .032 \\
\hline 8,270 & 2,020 & 393 & 5.14 & 4.09 & .32 & .00089 & .00087 & 3.8 & .031 \\
\hline$* 8,300$ & 2,070 & 394 & 5.24 & 4.02 & .31 & .00084 & .00082 & 4.0 & .031 \\
\hline 8,450 & 2,090 & 394 & 5.29 & 4.05 & .31 & .00087 & .00085 & 4.0 & .032 \\
\hline 8,960 & 2,150 & 396 & 5.43 & 4.17 & .32 & .00094 & .00091 & 4.5 & .033 \\
\hline$* 9,540$ & 2,240 & 398 & 5.63 & 4.26 & .32 & .00087 & .00085 & 4.8 & .032 \\
\hline 10,700 & 2,390 & 400 & 5.96 & 4.48 & .32 & .00093 & .00090 & 5.5 & .032 \\
\hline 11,200 & 2,410 & 400 & 6.00 & 4.66 & .33 & .00093 & .00090 & 5.5 & .031 \\
\hline 11,500 & 2,470 & 402 & 6.12 & 4.67 & .33 & .00094 & .00091 & 5.9 & .032 \\
\hline 13,600 & 2,700 & 408 & 6.58 & 5.05 & .35 & .00097 & .00093 & 7.3 & .031 \\
\hline 14,100 & 2,720 & 409 & 6.62 & 5.20 & .36 & .00099 & .00095 & 7.5 & .031 \\
\hline 14,700 & 2,820 & 410 & 6.84 & 5.22 & .35 & .00097 & .00093 & 8.0 & .031 \\
\hline 14,800 & 2,820 & 410 & 6.85 & 5.25 & .35 & .00097 & .00093 & 8.0 & .031 \\
\hline 15,000 & 2,850 & 411 & 6.91 & 5.26 & .35 & .00090 & .00087 & 8.0 & .030 \\
\hline 15,800 & 2,920 & 412 & 7.05 & 5.42 & .36 & .00096 & .00092 & 8.2 & .030 \\
\hline 20,100 & 3,360 & 419 & 7.96 & 5.99 & .37 & .00101 & .00097 & 10.2 & .031 \\
\hline$\$ 26,500$ & 3,910 & 429 & 9.06 & 6.77 & .40 & .00104 & .00100 & 12.0 & .030 \\
\hline
\end{tabular}

* The data used for this n-value calculation wcre collected during the growing season.

$\ddagger$ The right-bank overflow area at cross section 1 is treated as ineffective-flow area for this $\mathbf{n}$-value calculation. 


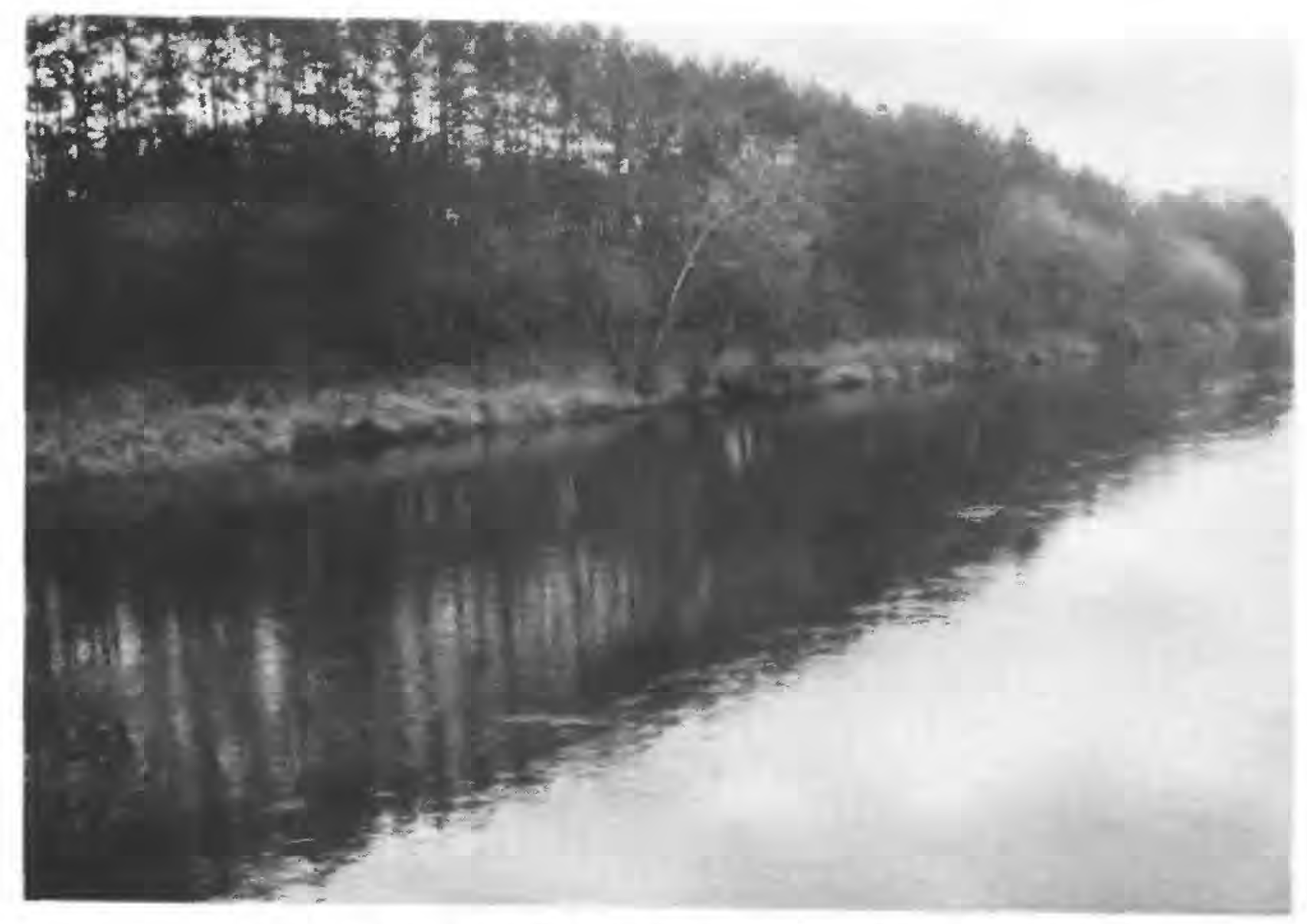

View from cross section 1, facing downstream toward left bank.

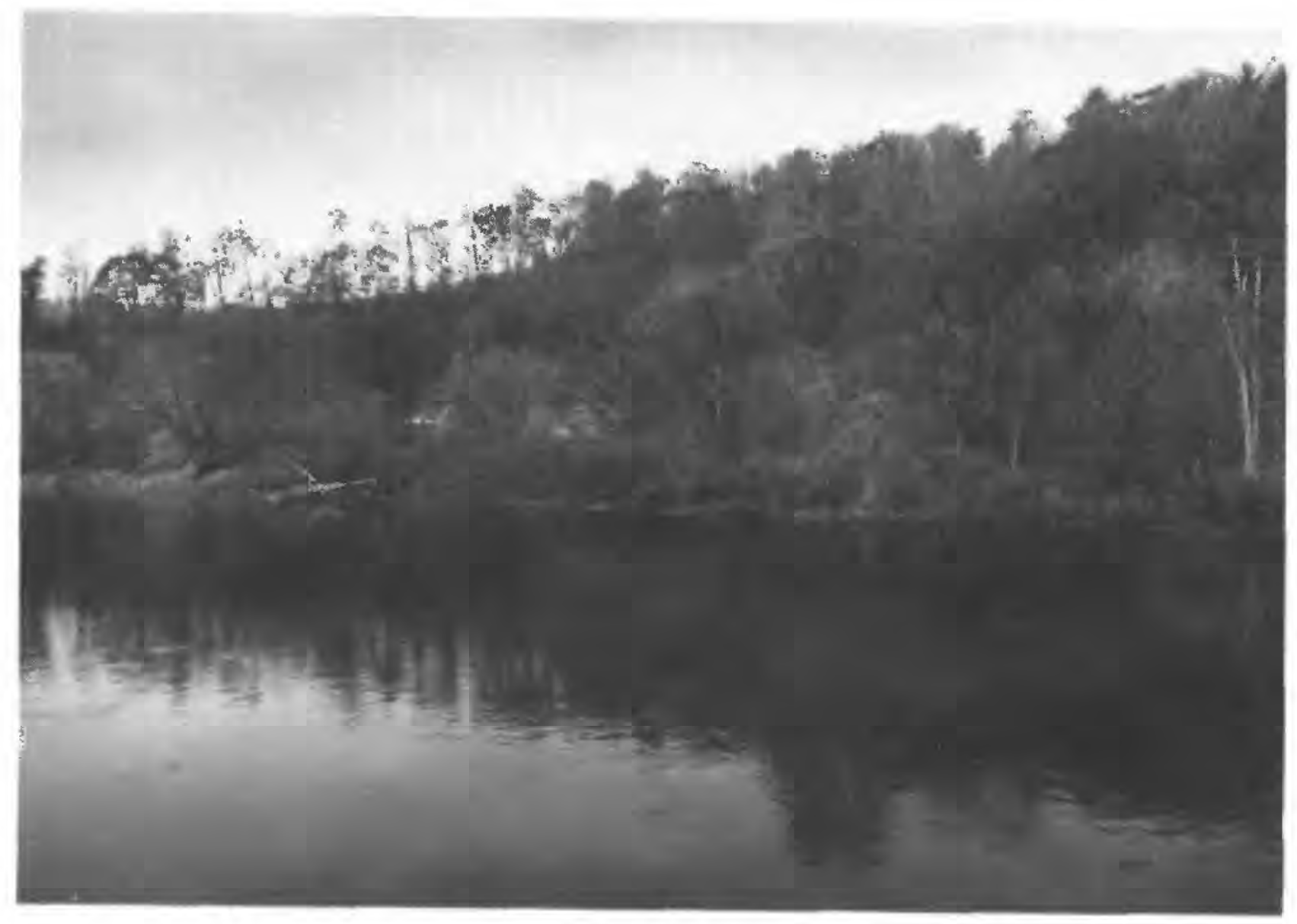

View from cross section 1, facing downstream toward right bank.

Figure A2-19. Chenango River near Chenango Forks, N.Y. A. Photographs during late fall. 


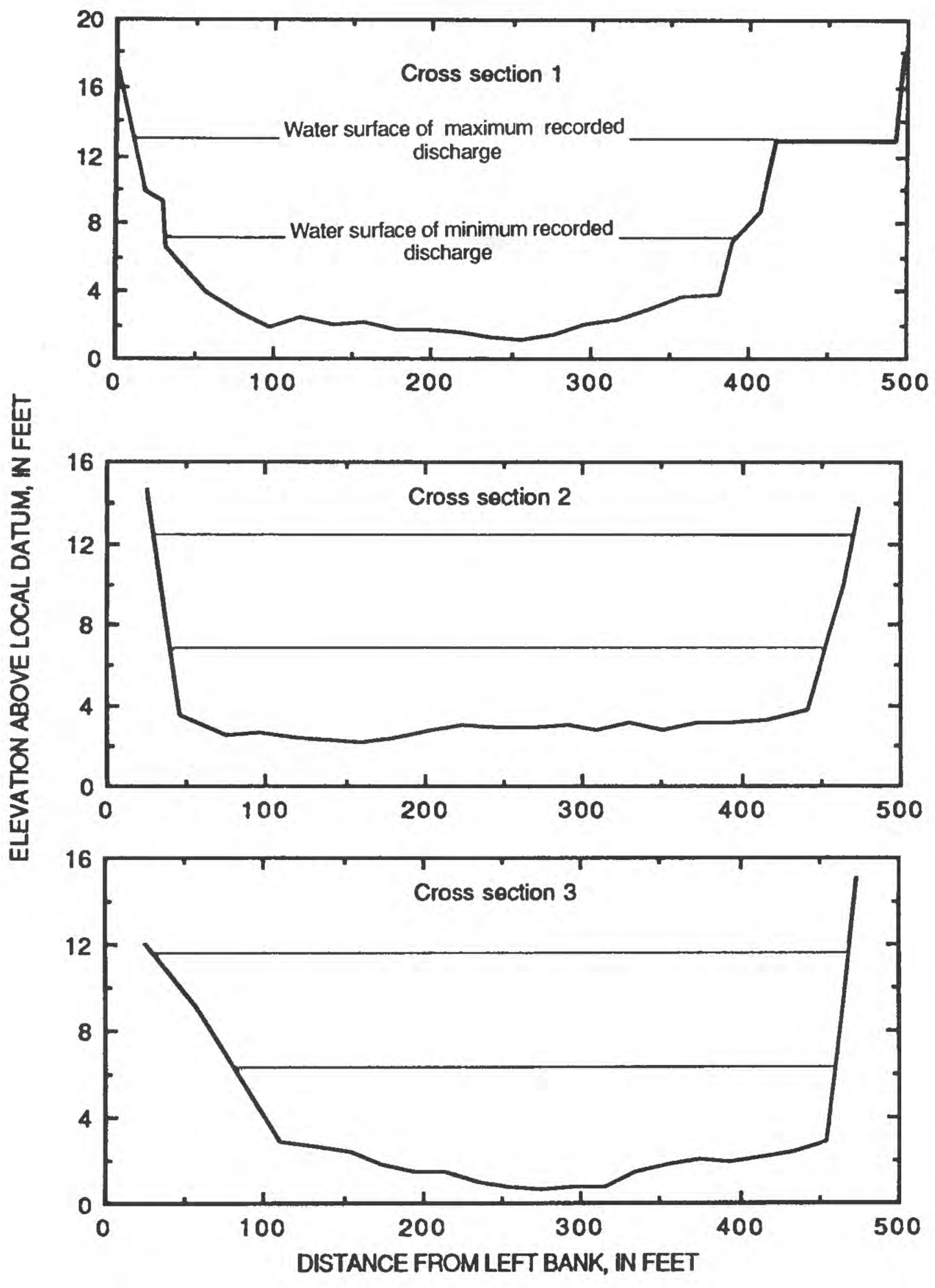

Figure A2-19. Chenango River near Chenango Forks, N.Y. (continued). in plan view on p. 119.)

B. Cross sections. (Locations are shown 
PLAN VIEW (not to scale)
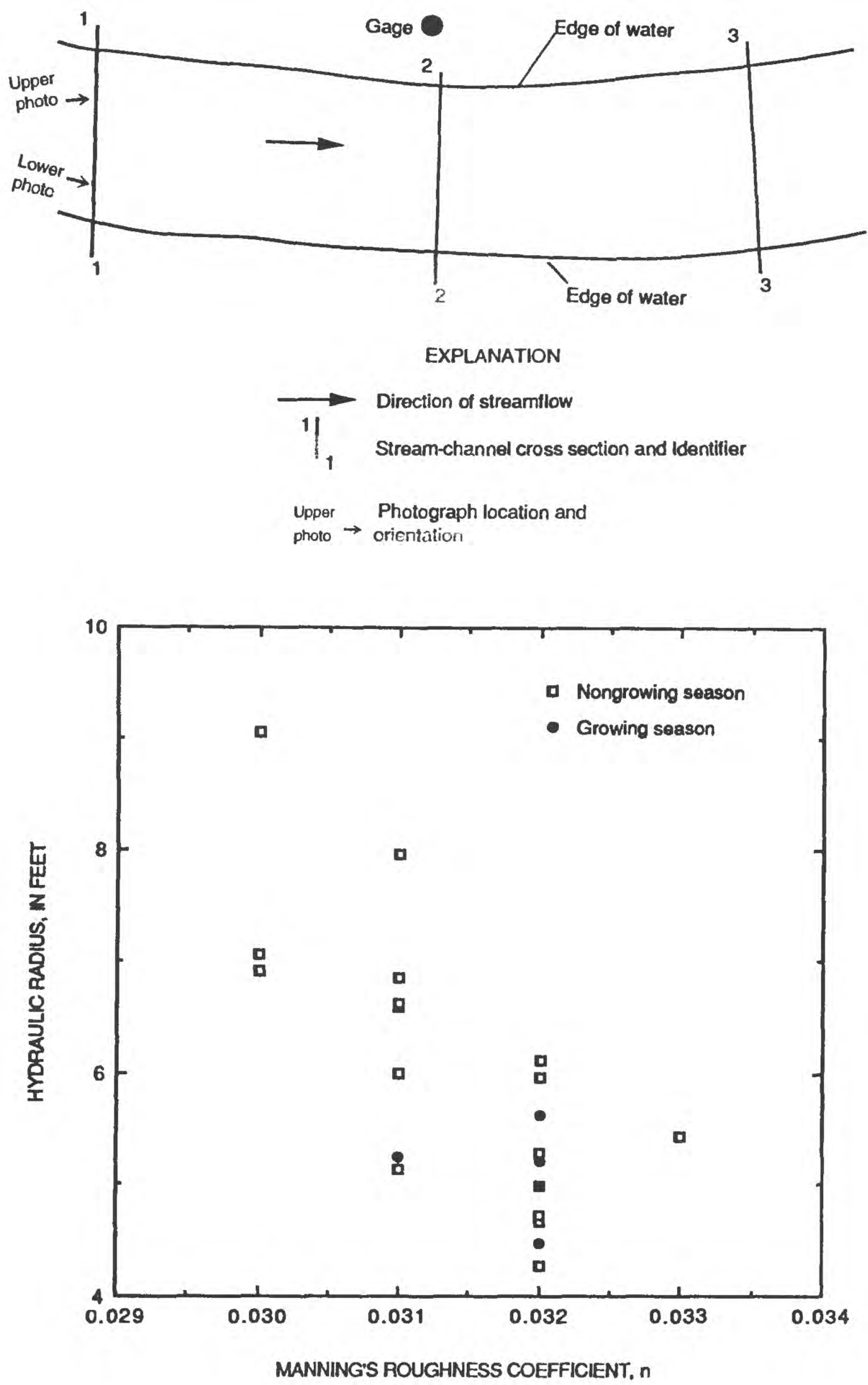

Figure A2-19. Chenango River near Chenango Forks, N.Y. (continued). C. Plan view and relation between hydraulic radius and Manning's roughness coefficient during growing and nongrowing seasons. 


\section{SITE 20. GENESEE RIVER NEAR MOUNT MORRIS, N.Y.}

Table A2-20. Station description and hydraulic data

Location.--Latitude $42^{\circ} 46^{\prime} 00^{\prime \prime}$, longitude $77^{\circ} 50^{\prime} 21^{\prime \prime}$, Livingston County, on right bank $100 \mathrm{ft}$ north of Jones Bridge Road, $0.8 \mathrm{mi}$ downstream from Canaseraga Creek, $2.8 \mathrm{mi}$ northeast of Mount Morris and $63.0 \mathrm{mi}$ upstream from mouth. A 3-section, 1,000-ft-long reach; section 1 is $170 \mathrm{ft}$ downstream from gage.

USGS station-identification number.--04227500.

Drainage area.-1,424 $\mathrm{mi}^{2}$.

Bed material.--Gravel with some cobbles. Intermediate diameter $\mathrm{d}_{50}=0.11$ and $\mathrm{d}_{84}=0.18 \mathrm{ft}$. Minimum diameter $\mathrm{d}_{50}=0.06 \mathrm{ft}$.

Bank description.--Right bank is grass-lined with trees near top of bank. Left bank has grass, dense brush, trees, and overhanging branches from top of bank. Vegetation indices: 1, 1.

Remarks.--Flow is regulated by Mount Morris Lake. The $\mathrm{n}$ values computed at this site are affected by 2- to 8-percent flow-area expansion in the reach. The velocity-head coefficients computed from discharge measurements made at this site range from 1.06 to 1.31 for discharges between 3,300 and $7,700 \mathrm{ft}^{3} / \mathrm{s}$.

\section{Hydraulic Data}

[ $\mathrm{ft}=\mathrm{feet} ; \mathrm{ft}^{2}=$ square feet; $\mathrm{ft} / \mathrm{s}=$ feet per second; $\mathrm{ft}^{3} / \mathrm{s}=$ cubic feet per second. $]$

\begin{tabular}{|c|c|c|c|c|c|c|c|c|c|}
\hline \multirow[b]{2}{*}{$\begin{array}{c}\text { Discharge } \\
\left(\mathrm{ft}^{3} / \mathrm{s}\right)\end{array}$} & \multicolumn{5}{|c|}{ Avcrage values for reach } & \multirow[b]{2}{*}{$\begin{array}{l}\text { Water- } \\
\text { surface } \\
\text { slope }\end{array}$} & \multirow[b]{2}{*}{$\begin{array}{l}\text { Energy } \\
\text { gradient }\end{array}$} & \multirow[b]{2}{*}{$\begin{array}{c}\text { Percent } \\
\text { wetted } \\
\text { perimeter } \\
\text { vegetated }\end{array}$} & \multirow[b]{2}{*}{$\underset{n}{\text { Manning's }}$} \\
\hline & $\begin{array}{l}\text { Arca } \\
\left(\mathrm{ft}^{2}\right)\end{array}$ & $\begin{array}{l}\text { Width } \\
\text { (ft) }\end{array}$ & $\begin{array}{l}\text { Hydraulic } \\
\text { radius } \\
\text { (ft) }\end{array}$ & $\begin{array}{c}\text { Velocity } \\
(\mathrm{ft} / \mathrm{s})\end{array}$ & $\begin{array}{l}\text { Froude } \\
\text { number }\end{array}$ & & & & \\
\hline 3,320 & 871 & 136 & 6.23 & 3.81 & 0.27 & 0.00048 & 0.00046 & 12.1 & 0.028 \\
\hline 3,920 & 946 & 138 & 6.66 & 4.15 & .28 & .00041 & .00039 & 13.4 & .025 \\
\hline 5,360 & 1,230 & 145 & 8.21 & 4.35 & .26 & .00041 & .00039 & 18.0 & .028 \\
\hline 5,400 & 1,240 & 146 & 8.25 & 4.35 & .26 & .00037 & .00035 & 18.5 & .026 \\
\hline$* 5,600$ & 1,240 & 146 & 8.24 & 4.52 & .27 & .00037 & .00035 & 18.5 & .025 \\
\hline 6,720 & 1,450 & 151 & 9.23 & 4.64 & .26 & .00032 & .00031 & 21.6 & .025 \\
\hline$* 6,930$ & 1,500 & 152 & 9.45 & 4.63 & .26 & .00032 & .00031 & 22.6 & .025 \\
\hline 7,740 & 1,640 & 157 & 10.05 & 4.71 & .26 & .00032 & .00031 & 25.0 & .026 \\
\hline
\end{tabular}

* The data used for this n-value calculation were collected during the growing season. 


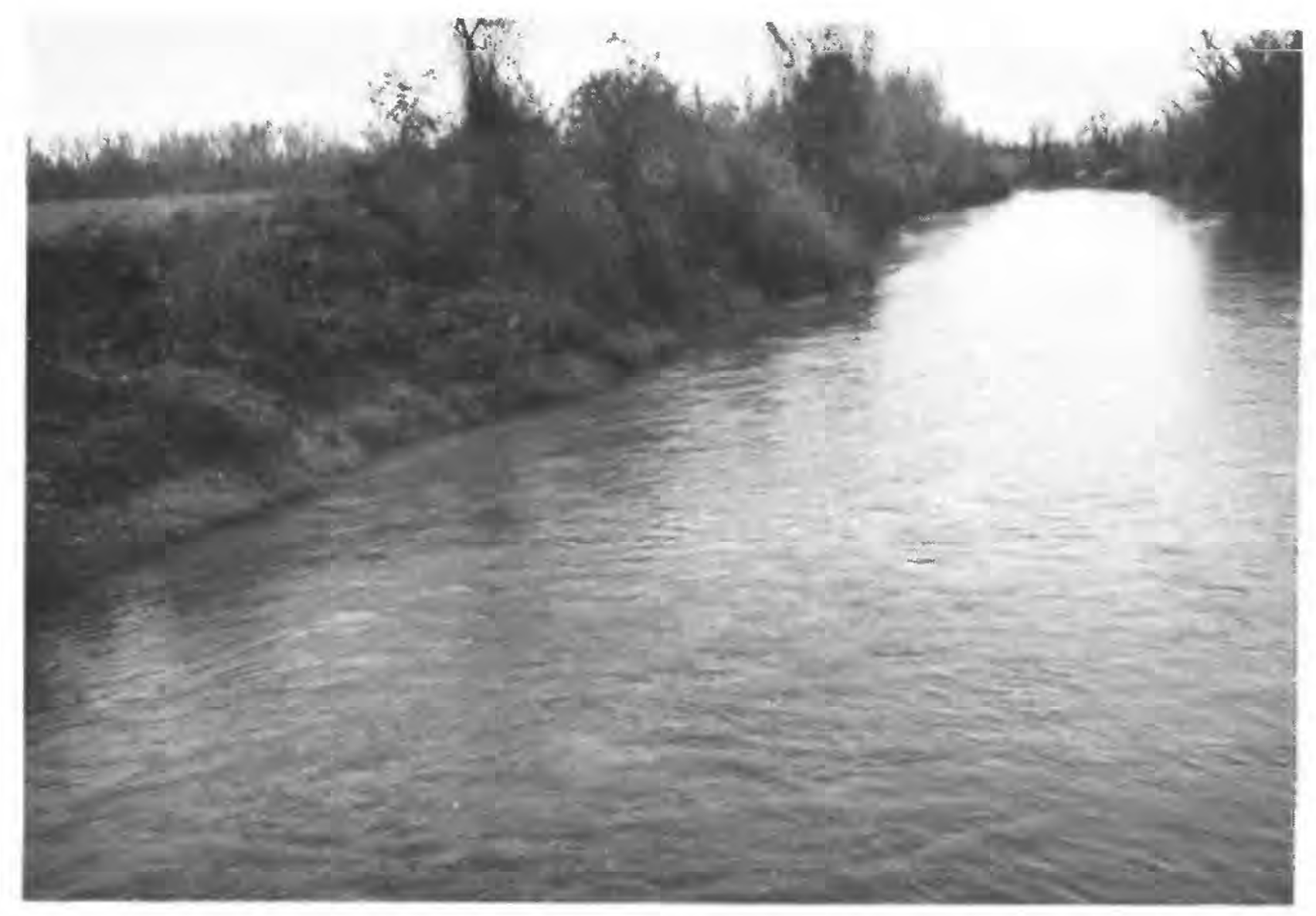

View from above cross section 1, facing downstream toward left bank.

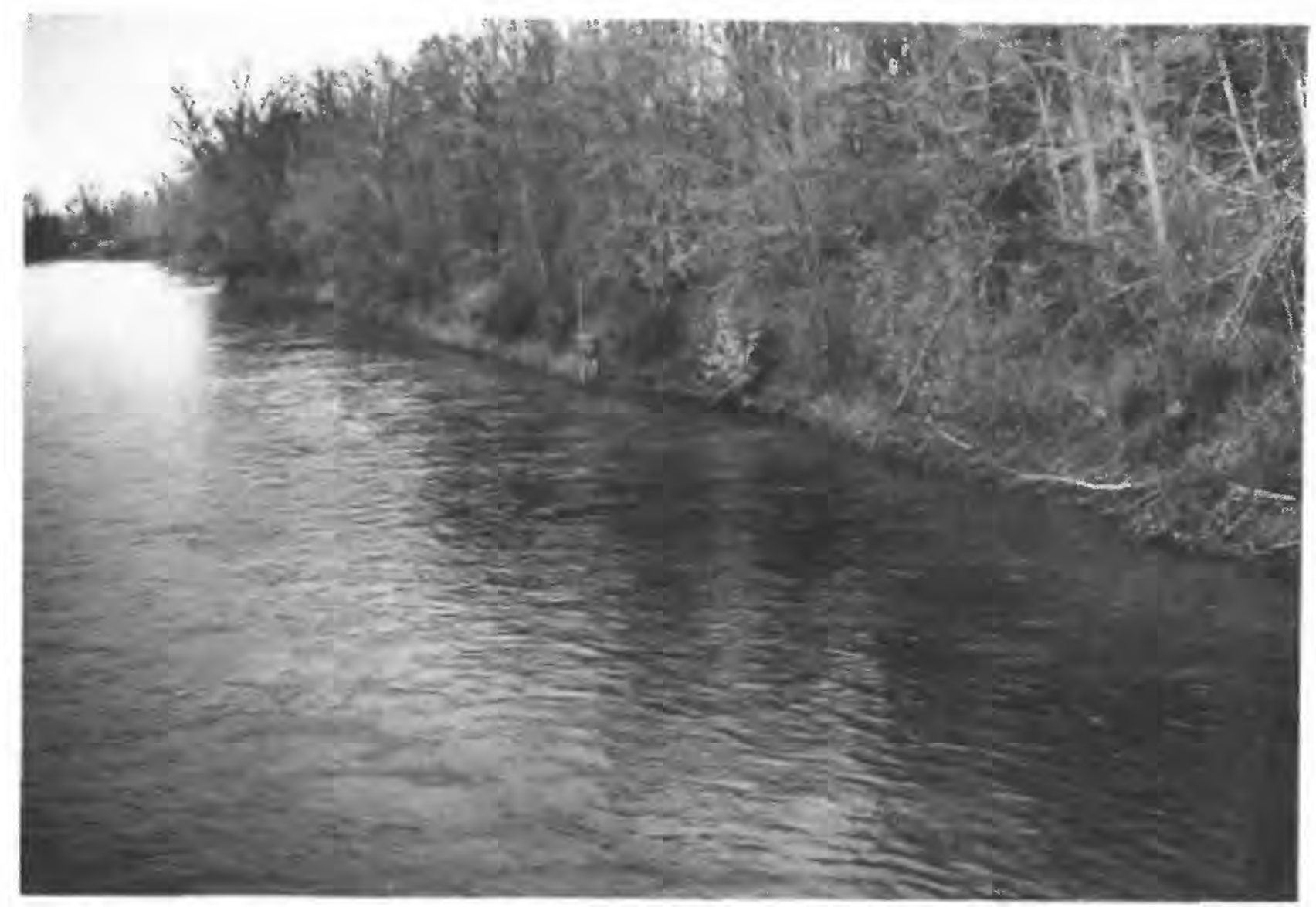

View from above cross section 1, facing downstream toward right bank. Hydrographer is at section 1 holding a stadia rod extended $15 \mathrm{ft}$.

Figure A2-20. Genesee River near Mount Morris, N.Y. A. Photographs during late fall. 

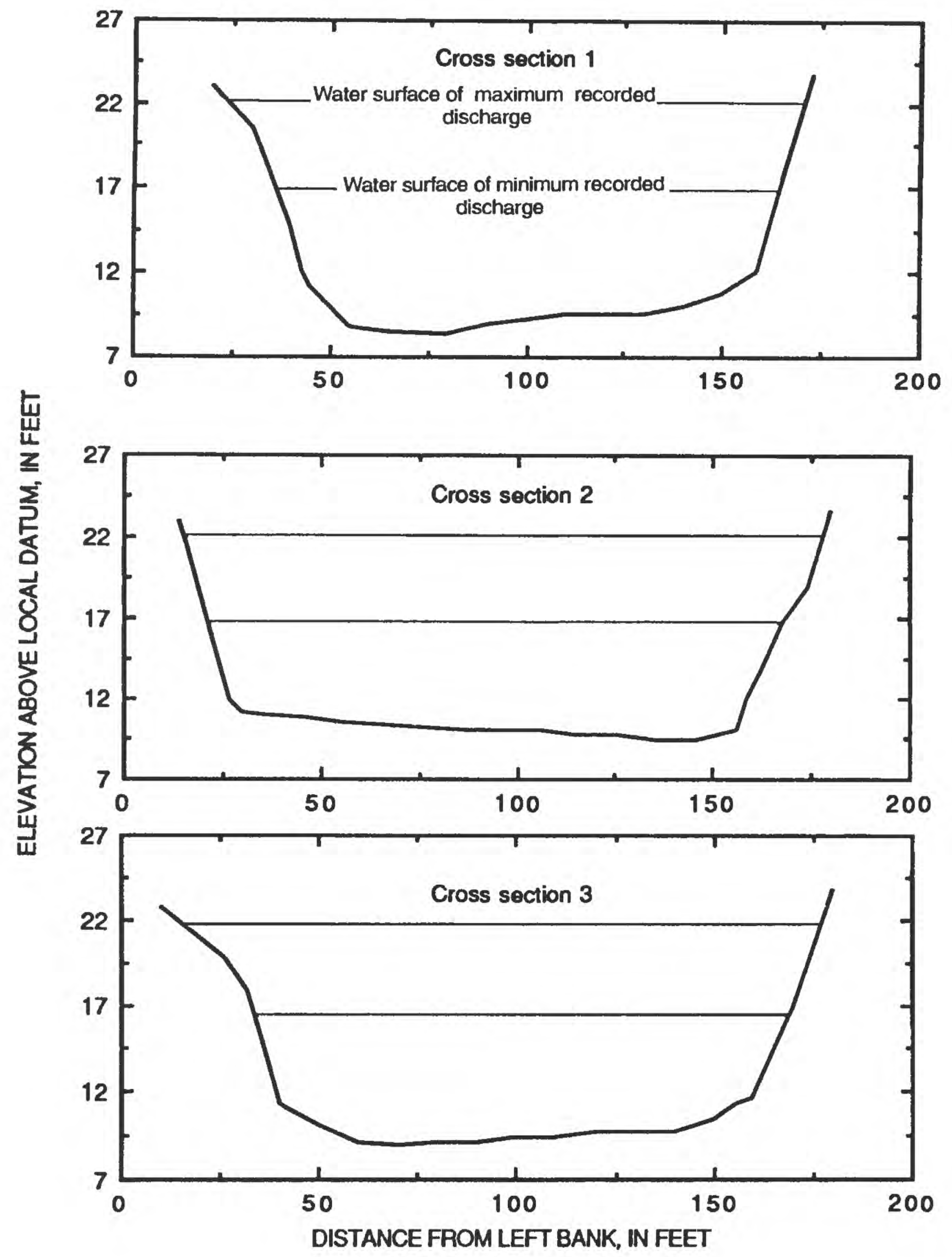

Flgure A2-20. Genesee River near Mount Morris, N.Y. (continued). B. Cross sections. (Locations are shown in plan view on p. 123.) 


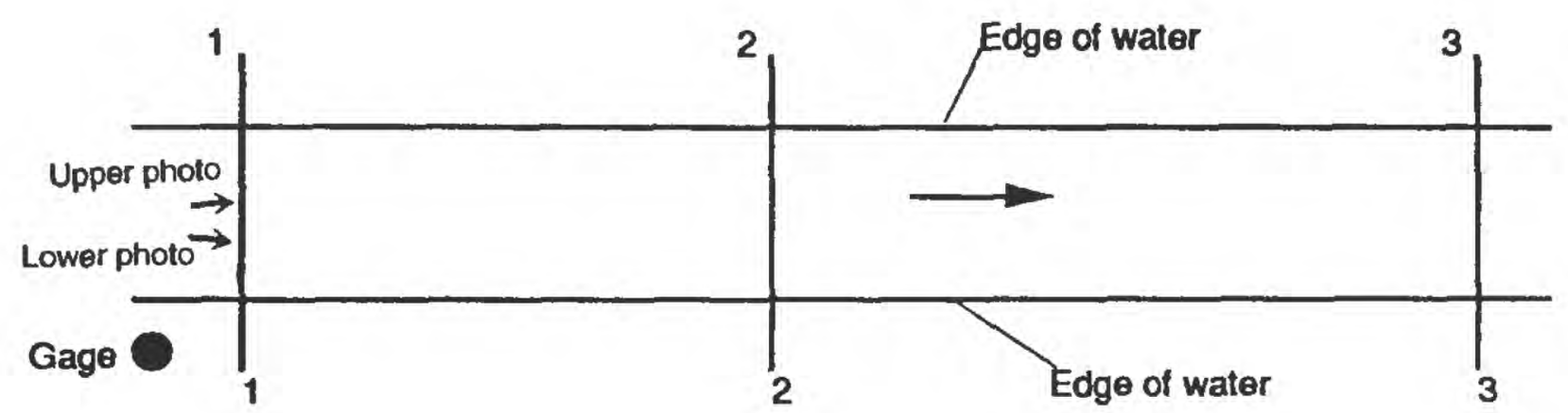

\section{EXPLANATION}
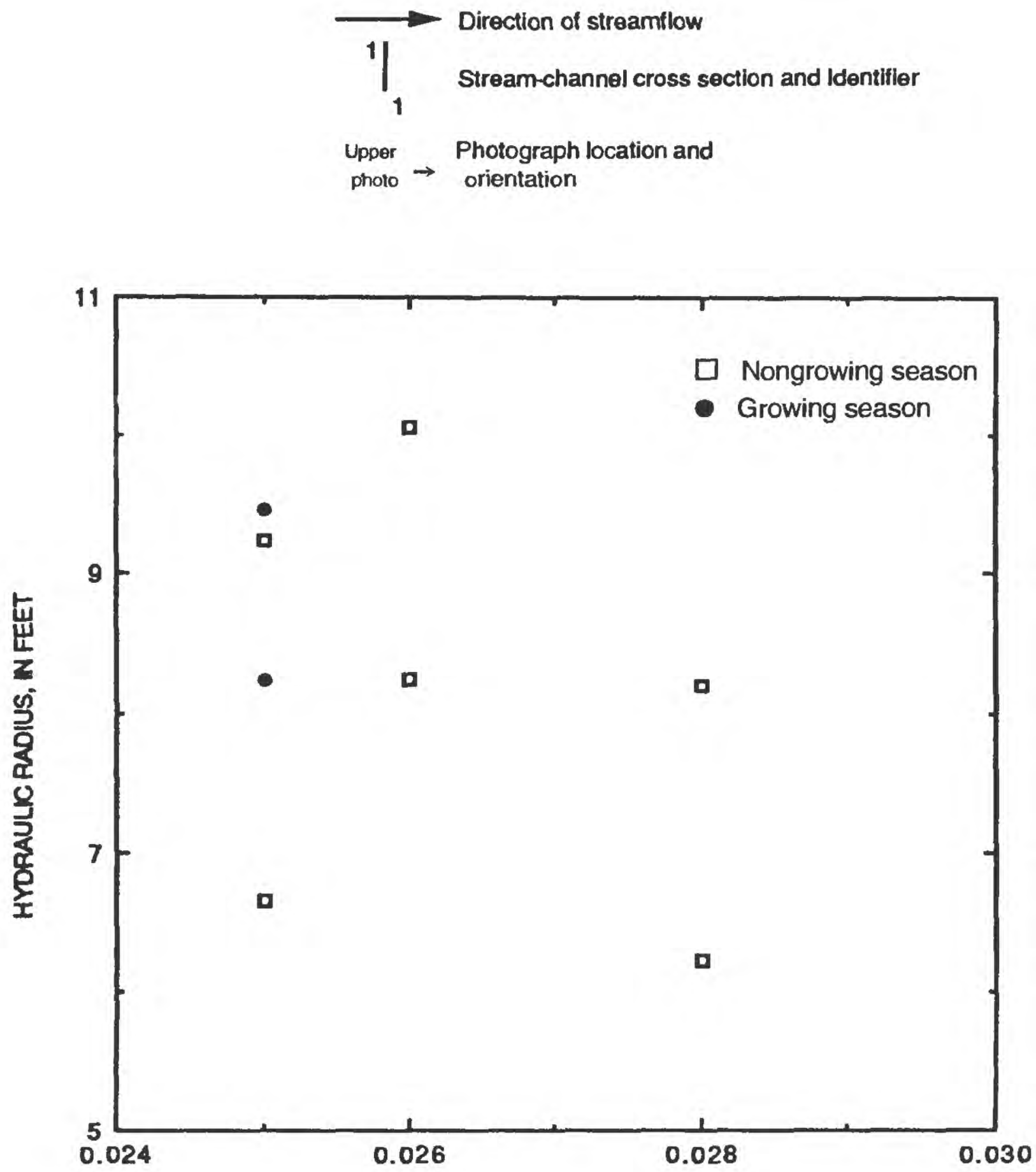

MANNING'S ROUGHNESS COEFFICIENT, $n$

Figure A2-20. Genesee River near Mount Morris, N.Y. (continued). C. Plan view and relation between hydraulic radius and Manning's roughness coefficient during growing and nongrowing seasons. 


\section{SITE 21. TROUT RIVER AT TROUT RIVER, N.Y.}

Table A2-21. Station description and hydraulic data

Location.--Latitude $44^{\circ} 59^{\prime} 23^{\prime \prime}$, longitude $74^{\circ} 17^{\prime} 56^{\prime \prime}$, Franklin County, at bridge on county highway, $0.2 \mathrm{mi}$ east of State Highway 30 , at Trout River, 0.5 mi upstream from international boundary, 1.5 mi downstream from unnamed tributary, and 3.3 mi downstream from Little Trout River. A 3-section, 505-ft-long reach; section 1 is at the gage.

USGS station-identification number.--04270700.

Drainage area.--107 $\mathrm{mi}^{2}$.

Bed material.--Primarily pitted and grooved bedrock, 25 percent of which is overlain by angular cobbles and gravel. Intermediate diameter $\mathrm{d}_{50}=$ about 0.15 and $\mathrm{d}_{84}=$ about $0.22 \mathrm{ft}$. Minimum diameter $d_{50}$ not determined.

Bank description.--Both banks are vegetated with grass and annual plants along their lower parts and with trees, 0.5 to $1.5 \mathrm{ft}$ in diameter, beyond. Trees are smaller and more densely spaced (about 20 $\mathrm{ft}$ apart) on right bank than on left. Vegetation indices: $0.5,1.5$.

\section{Hydraulic Data}

$\left[\mathrm{ft}=\mathrm{feet} ; \mathrm{ft}^{2}=\right.$ square feet; $\mathrm{ft} / \mathrm{s}=$ feet per second; $\mathrm{ft}^{3} / \mathrm{s}=$ cubic feet per second. $]$

\begin{tabular}{|c|c|c|c|c|c|c|c|c|c|}
\hline \multirow[b]{2}{*}{$\begin{array}{c}\text { Discharge } \\
\left(\mathrm{ft}^{3} / \mathrm{s}\right)\end{array}$} & \multicolumn{5}{|c|}{ Average values for reach } & \multirow[b]{2}{*}{$\begin{array}{c}\text { Water- } \\
\text { surface } \\
\text { slope }\end{array}$} & \multirow[b]{2}{*}{$\begin{array}{c}\text { Energy } \\
\text { gradient }\end{array}$} & \multirow[b]{2}{*}{$\begin{array}{c}\text { Percent } \\
\text { wetted } \\
\text { perimeter } \\
\text { vegetated }\end{array}$} & \multirow[b]{2}{*}{$\begin{array}{c}\text { Manning's } \\
n\end{array}$} \\
\hline & $\begin{array}{l}\text { Area } \\
\left(\mathrm{ft}^{2}\right)\end{array}$ & $\begin{array}{c}\text { Width } \\
\text { (ft) }\end{array}$ & $\begin{array}{l}\text { Hydraulic } \\
\text { radius } \\
\text { (ft) }\end{array}$ & $\begin{array}{c}\text { Velocity } \\
\text { (ft/s) }\end{array}$ & $\begin{array}{l}\text { Froude } \\
\text { number }\end{array}$ & & & & \\
\hline 204 & 142 & 90.5 & 1.57 & 1.45 & 0.21 & 0.00160 & 0.00157 & 3.0 & ${ }^{\mathrm{a}} 0.055$ \\
\hline 606 & 226 & 95.7 & 2.32 & 2.71 & .31 & .00212 & .00201 & 9.2 & ${ }^{b} .044$ \\
\hline 830 & 258 & 96.8 & 2.61 & 3.25 & .35 & .00234 & .00218 & 10.4 & ${ }^{b} .041$ \\
\hline 3,300 & 523 & 104 & 4.83 & 6.34 & .50 & .00345 & .00304 & 18.3 & ${ }^{\mathrm{c}} .037$ \\
\hline 3,810 & 553 & 104 & 5.07 & 6.92 & .53 & .00396 & .00340 & 19.1 & ${ }^{\mathrm{c}} .037$ \\
\hline
\end{tabular}

$\S$ The $\mathrm{n}$ values computed for the subreaches differ by

a 0.008 ;

b 0.013 ;

${ }^{\mathrm{c}} 0.018$. 


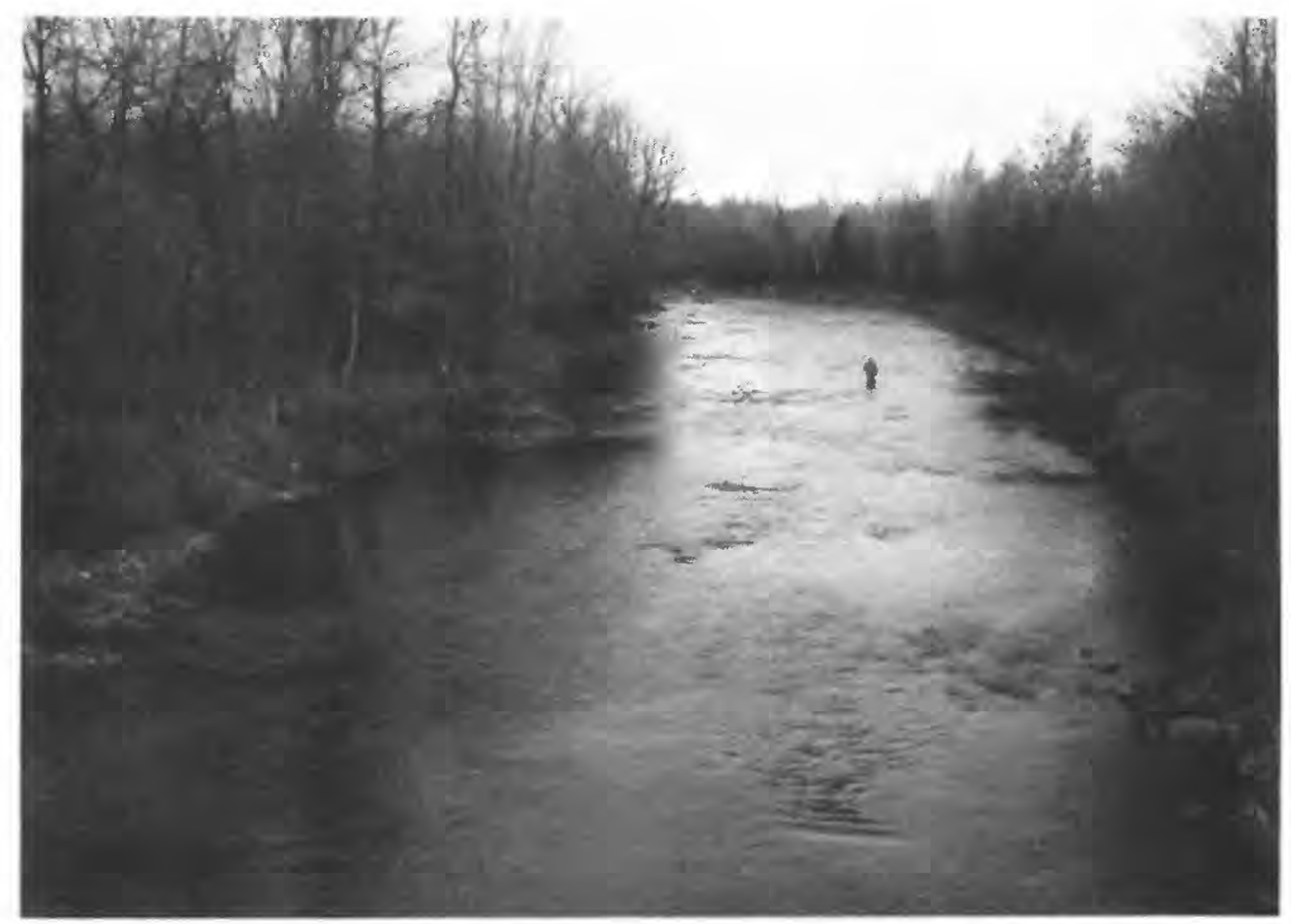

View from cross section 1, facing downstream toward left bank. Hydrographer is section 2.

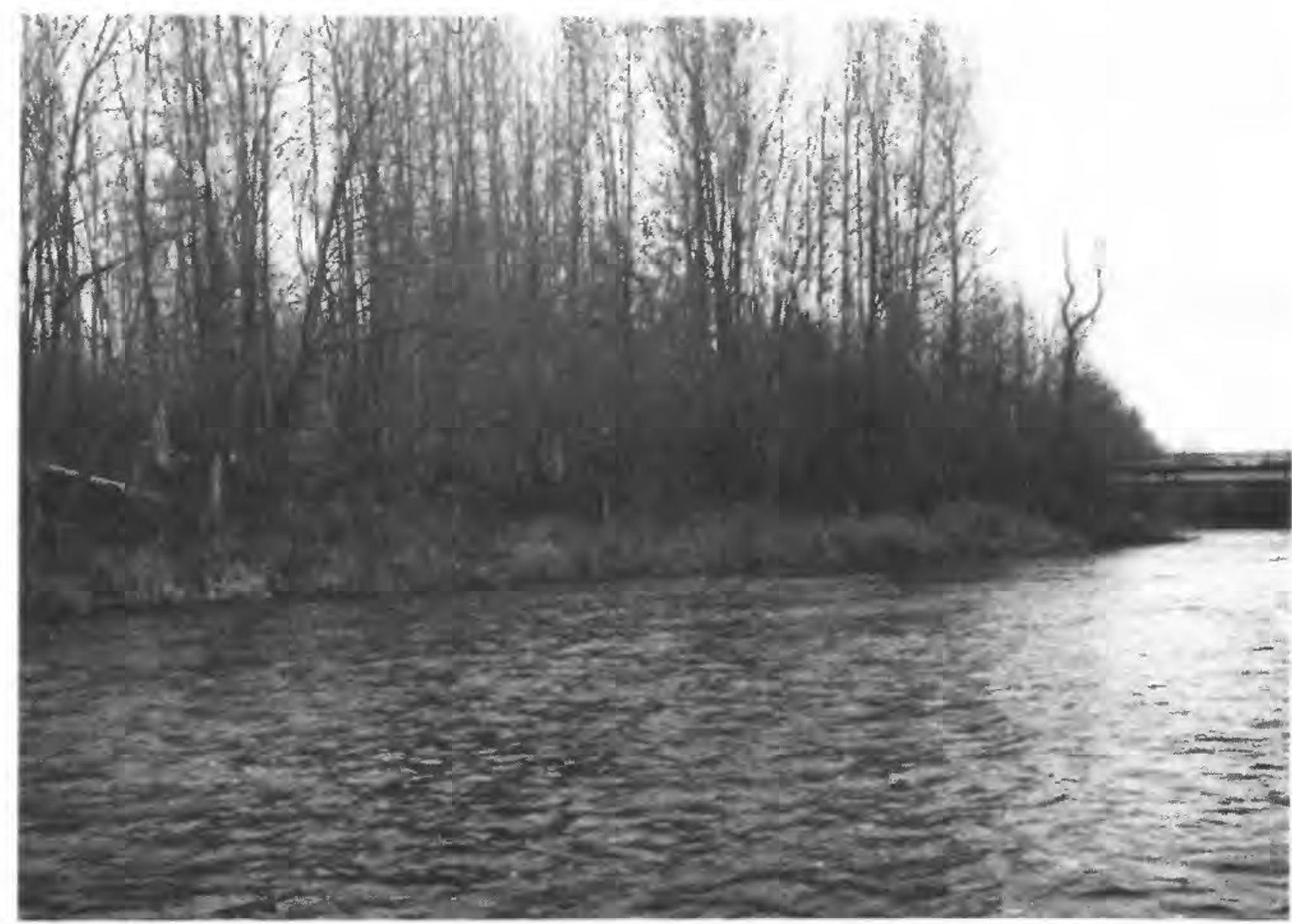

View from cross section 3, facing upstream toward right bank. Hydrographer is at section 2 standing at approximate water-surface elevation of maximum recorded discharge.

Figure A2-21. Trout River at Trout River, N.Y. A. Photographs during late fall. 

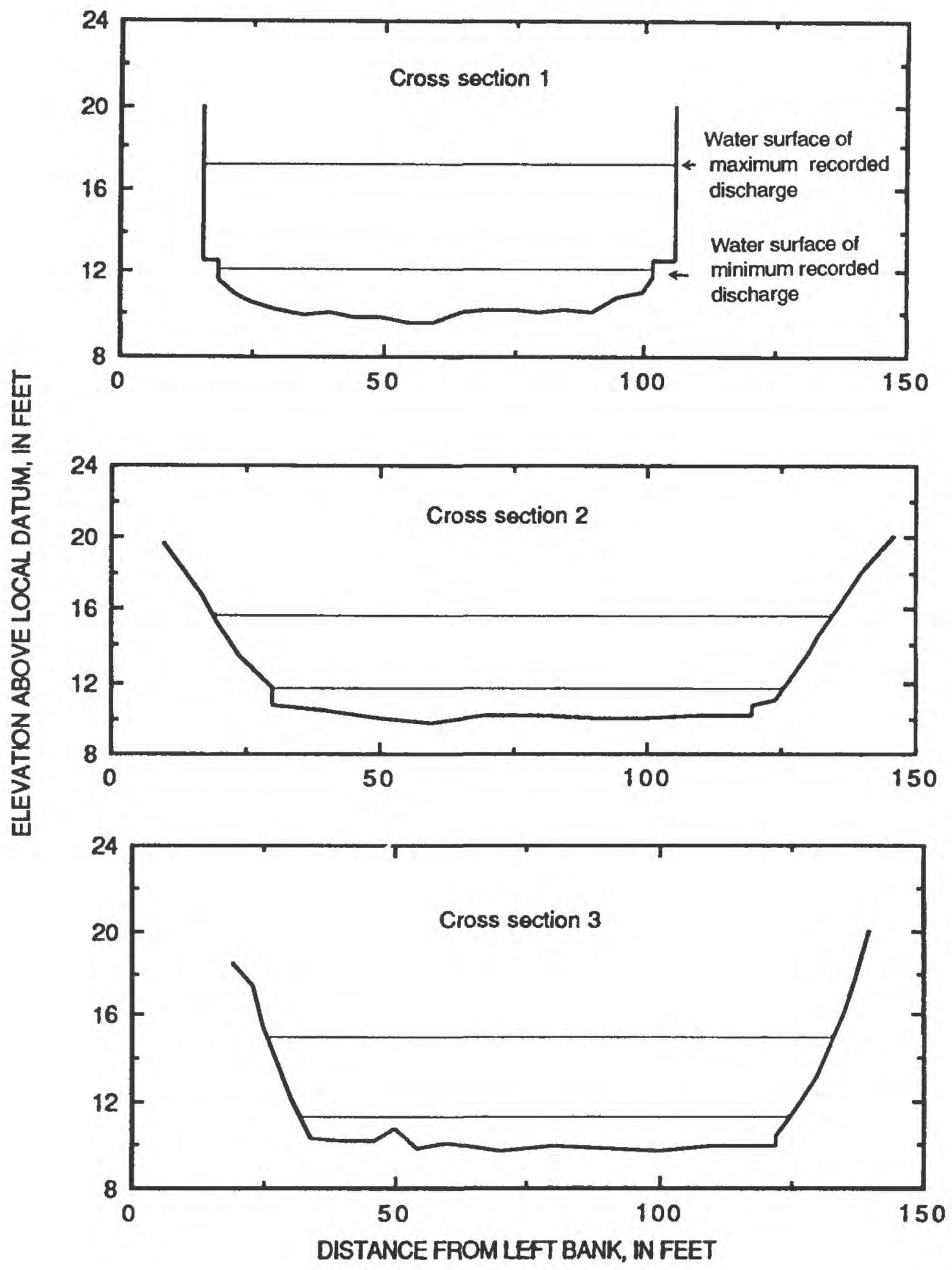

Figure A2-21. Trout River at Trout River, N.Y. (continued). view on p. 127.)

B. Cross sections. (Locations are shown in plan 
PLAN VIEW (not to scale)

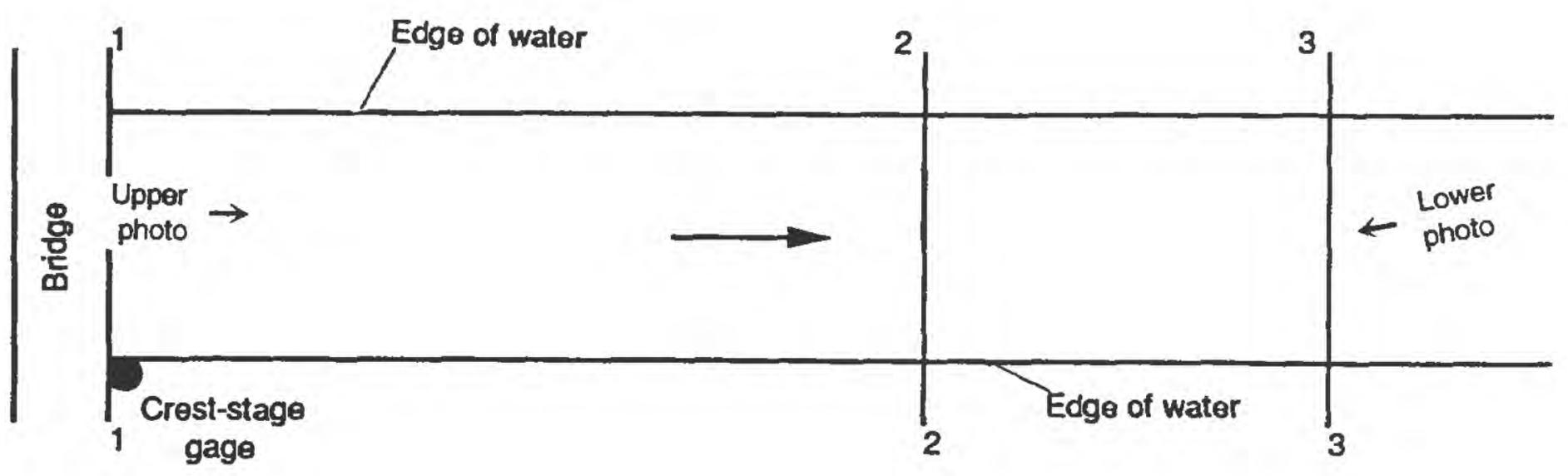

EXPLANATION
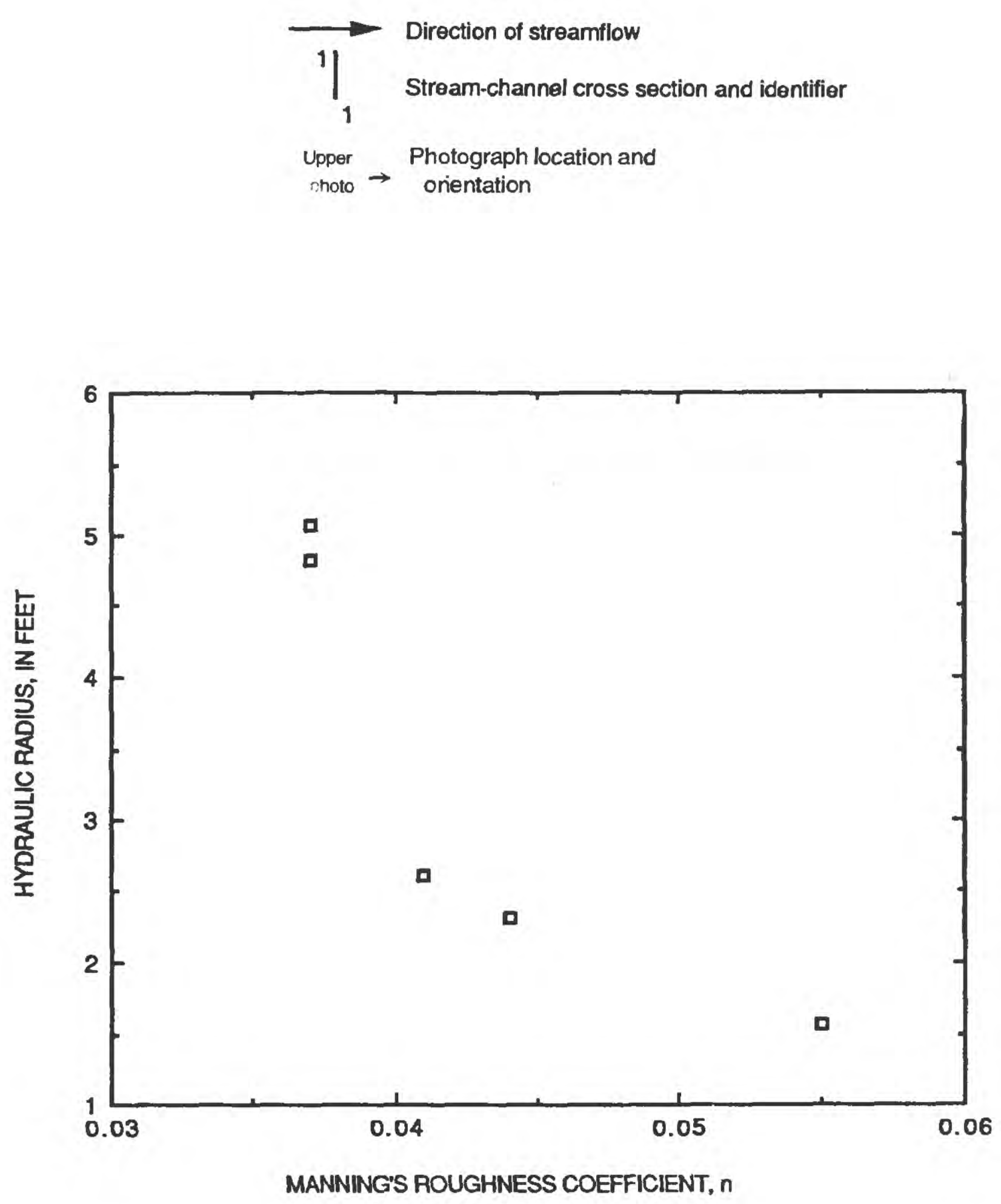

Figure A2-21. Trout River at Trout River, N.Y. (continued). C. Plan view and relation between hydraulic radius and Manning's roughness coefficient. 